Excavations at Seibal

Department of Peten, Guatemala

This book was prepared as an account of work sponsored by an agency of the United States Government. Neither the United States Government nor any agency thereot, nor any of their employees, makes any warranty, express or implied, or assumes any legal liability of responsibility for the accuracy, rempresents that its use would not infringe priverely owned rights, Peference herein disclosed, of commercial product, process, or service by trade name, trademark, manufacturer, or otherwise, does not necessarily constitute or imoly its endorsement, recommendation, or favoring by the United States Government or any agency thereof. The views and opinions of authors expressed herein do not

\title{
ANALYSES OF FINE PASTE CERAMICS
}

Edited By

Jeremy A. Sabloff

with

contributions by

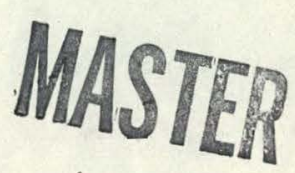

Ronald L. Bishop

Garman Harbottle

Robert L. Rands

Jeremy A. Sabloff

Edward $\nabla$. Sayre

Research carried out under the auspices of the United States

Department of Energy under contract no. DE-ACO2-76CH00016.

Peabody Museum Memoir

Volume 15 ,

Number 2 


\section{DISCLAIMER}

This report was prepared as an account of work sponsored by an agency of the United States Government. Neither the United States Government nor any agency Thereof, nor any of their employees, makes any warranty, express or implied, or assumes any legal liability or responsibility for the accuracy, completeness, or usefulness of any information, apparatus, product, or process disclosed, or represents that its use would not infringe privately owned rights. Reference herein to any specific commercial product, process, or service by trade name, trademark, manufacturer, or otherwise does not necessarily constitute or imply its endorsement, recommendation, or favoring by the United States Government or any agency thereof. The views and opinions of authors expressed herein do not necessarily state or reflect those of the United States Government or any agency thereof. 


\section{DISCLAIMER}

Portions of this document may be illegible in electronic image products. Images are produced from the best available original document. 


\section{ANALYSES OF FINE PASTE CERAMICS}

\section{CONTENTS}

Chapter One: Introduction: A Brief Informal History of the Brookhaven Fine Paste Ceramics Project JEREMY A. SABLOFF

Chapter Two: Chemical and Mathematical Procedures Employed in the Mayan Fine Paste Ceramics Profect RONALD L. BISHOP, GARMAN HARBOTTLE, and EDWARD V. SAYRE

Chapter Three: Mayan Fine Paste Ceramics: A Conpositional Perspective RONALD L. BISHOP and ROBERT L. RANDS

Chapter Four: Mayan Fine Paste Ceramics: An Archaenlogical Perspective ROBERT L. RANDS, RONALD L. BISHOP, and JEREMY A. SABLOFF 
Figure 1. Map of the Maya area. With the exception of Rixpek, s1tes shown are those represented by pottery from the Maya area that is analyzed in the present study.

F1gure 2. Q-mode Factor Plot of Fine Orange-Fine Gray Pottery

$\square$ Maya Area

Tuxt1as

$\triangle$ El Tajin

+ San Lorenzo

$\times$ Lambityeco

Figure 3. Log $|T| /|W|$ for 14 Varlables and 10 Components

Figure 4. Chemical Paste Compositional Reference Units, D1scriminant Axes 1 and 2

F1gure 5. Chemfcal Paste Compositional Reference Units, D1scriminant Axes 1 and 3

F1gure 6. Chemical Paste Compositonal Reference Units, Discriminant Axes 2 and 3

F1gure 7: Chemical Paste Compositional Reference Units, Volcanic Dust Abundance
$0 \quad$ Absent
I Trace
R Rare
C Common
No petrographic analysis 
F1gure 8. Chemical Paste Compositonal Reference Untts, Provenfence

$$
\text { Symbols }
$$

$\begin{array}{ll}\text { A Altar de Sacriflclos } \\ \text { S } & \text { Selbal } \\ \text { N } & \text { Pledras Negras } \\ \text { P } & \text { Palenque } \\ \text { C } & \text { Calatrava } \\ \text { J Jonuta } \\ \text { E } & \text { Tecolpan } \\ \text { T } & \text { Trinidad } \\ \text { Y } & \text { Yucatan, Campeche } \\ \text { M Miscellaneous }\end{array}$

Flgure 9. Chemlcal Paste Compositional Reference Units, "Upstream" -

"Downstream" Symbols

$$
\begin{array}{ll}
\text { O } & \text { Upstream } \\
\text { D } & \text { Downstream } \\
\text { P } & \text { Palenque } \\
\text { D Miscellaneous }
\end{array}
$$

Figure 10. Paste Compositional Reference Units, Discriminant Axes 1 and 2

Flgure 11. Maya PCRUs and Fine Orange or Fine Gray Pottery From

$$
\begin{aligned}
& \text { Non-Maya S1tes or Site Clusters } \\
& \text { 1-3 PCRUs (see F1g. 10) } \\
& 4 \text { Tortuguero } \\
& 5 \text { Tuxtlas } \\
& 6 \text { EI Tajin } \\
& 7 \text { San Lorenzo } \\
& \text { L Lambityeco } \\
& \text {, }
\end{aligned}
$$


List of Figures (cont'd) - $3-$

F1gure 12. Chemical Paste Compositional Reference Units, "Upstream" 3 and 4 Setoff
U Upstream
D Downstream
P Palenque
- Miscellaneous

F1gure 13. Paste Compositfonal Reference Untts, Symbols for Ceramic Ware

$$
\begin{aligned}
& \text { - Fine Orange Ware } \\
& \text { G Fine Gray Ware }
\end{aligned}
$$

F1gure 14. Paste Compositional Reference Units, Symbols for Ceramic Group

$$
\begin{array}{ll}
\text { Y } & \text { Altar } \\
Z & \text { Balancan } \\
\text { X } & \text { Silho } \\
\text { V } & \text { Matillas } \\
\text { T } & \text { Tres Naciones } \\
\text { C } & \text { Chablekal } \\
\text { O Unassigned Fine Orange } \\
\text { G Unassigned Fine Gray }
\end{array}
$$

Figure 15. Chemical Paste Compositonal Reference Units, Symbols for Ceramic Ware
- Fine Orange Ware
G Fine Gray Ware 
List of Figures (cont'd) - $4-$

F1gure 16. Chemical Paste Compositional Reference Onits, Symbols for

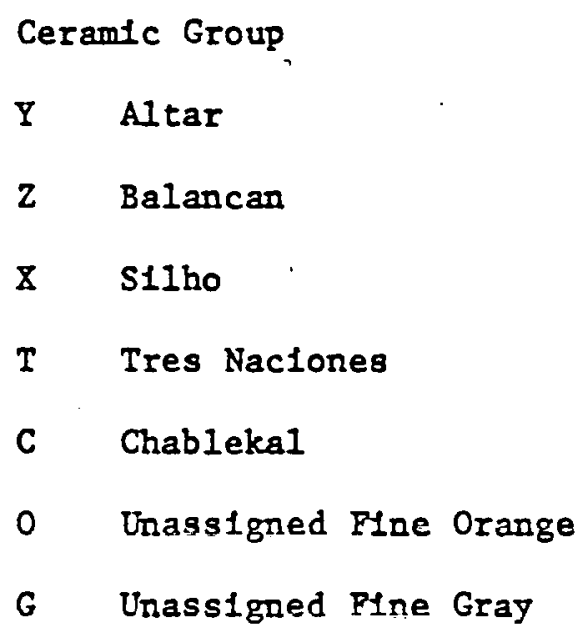

F1gure 17. Profectlons of "Outllers" onto D1scrlminant Axes Derfved for the Paste Compositional Reference Units, Symbis for Ceramie Group

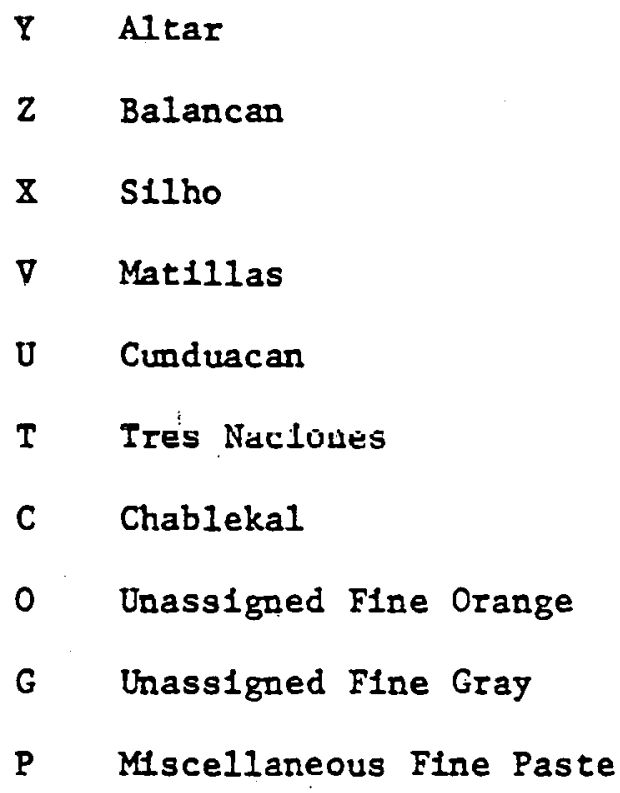


List of Figures (cont'd) - - 5 -

F1gure 18. Projection of "Outllers onto Discriminant Axes Derived for the Paste Compositional Reference Units, Symbols for Site Provenlence
A Altar
B Becan
C Comalcalco
N Pledras Negras
$P \quad$ Palenque
R Tortuguero
S Selbal
T Tierra Colorada
U Trinidad, T1erra Blanca
M Miscellaneous sites

Figure 19. Profection of "Outliers" onto Discriminant Axes Derived for the Paste Compositional Reference Units, Symbols for Micaceousness of Matrix

o Non intcaceous

1 Silghtly micaceous.

2. Medium micaceous

3. Micaceous

$4 \quad$ Very micaceous

- No analysis 
List of Figures (cont'd) - $6-$

Figure 20. Profection of "Outliers" onto Discriminant Axes Derfved for the Paste Compositional Reference Un1ts, Symbols for Abundance of Volcanic Dust
A Abundant
C Common
R Rare
T Trace
0 Absent
- No analysis

F1gure 21. Comblined CPCRU Micaceousness of Matrix ( $n=45$ )

Figure 22. Combined CPCRU Petrographic Profiles

-..-.-Muscovite

- - Blotite

Opal Phytoliths

-....-Volcanfc Dust

Figure 23. Chemical Paste Compositional Reference Units, Micaceousness of Matrix

$$
\begin{aligned}
-\operatorname{CPCRU} 1 & (n=7) \\
-\cdots \cdot \operatorname{CPCRU} 2 & (n=6) \\
---\operatorname{CPCRU} 3 & (n=8) \\
--\operatorname{CPCRU} 4 & (n=7) \\
-\cdots-\cdots-\operatorname{CPCRU} 5 & (n=17)
\end{aligned}
$$

Figure 24. Chemical Paste Compositional Reference Units, Abundance of Muscovite Grains

$$
\begin{aligned}
& \longrightarrow \operatorname{CPCRU} 1(\mathrm{n}=7) \quad-\longrightarrow \operatorname{CPCRU} 4(\mathrm{n}=7) \\
& \ldots \cdot \ldots \text { CPCRU } 2(n=6) \quad-\cdots-\cdots-C P C R U 5 \quad(n=18) \\
& ---\operatorname{CPCRU} 3(n=8)
\end{aligned}
$$


List of Figures (cont'd) - 7 -

Figure 25. Chemical Paste Compositlonal Reference Un1ts, Abundance of Blotite Grains

Symbols and "n" same as Flgure 24

Figure 26. Chemfcal Paste Compositional Reference Un1ts, Abundance of Volcanic Dust

Symbols and " $n$ " same as F1gure 24

F1gure 27. Chemfcal Paste Compositional Reference Un1ts, Abundance of Feldspar Grains

"n" same as F1gure 24

F1gure 28. Chemical Paste Compositional Reference Untts, Abundance Opal Phytoliths

Symbols and "n" same as F1gure 24

F1gure 29. Ceramlc Compleres of the Maya Late Classic and Postclassic Perlods. Reglons correspond to Table 10.

Figure 30. Chronology of Fine Gray Ware by Ceramic Groups

F1gure 31. Chronology of Fine Orange Ware by Ceramlc Groups

F1gure 32. Fine Orange Paste Figurine. Palenque, Specimen \#1174, Early Classic and Preclassic deposit, unplaced in CPCRUs.

F1gure 33. Early fine paste Including Fine Orange Ware (b, c)

a. Tortuguero, Spec1men $\$ 43$, black (compare Tzakol sharp Z-angle bowls), Tortuguero compositional group

b. Trinidad, Specimen 25, unnamed Incised orange, Taxinchan Ceramic Complex, unplaced in CPCRUs. 
List of Figures (cont'd) - $8-$

F1gure 33 (cont'd)

Figure 34. Fine Gray Ware, Chablekal Ceramfc Group. a-c. Palenque, Balunte Ceramlc Complex; d. TLerra Blanca, Naab Ceramlc Complex.
a. Spec1men \#373, Chablekal Gray Type
b. Specimen 329 , ChIcxulub Inc1sed Type
\&. Spec1men 1722;. Telchac Composite Type
d. Spec1men \#36, Telchac Composite Type.
a. CPCRU 1; b-d. Unplaced in CPCRUs.

F1gure 35. Fine Gray Ware, Chablekal Ceramic Group.

a. Pledras Negras, Specimen $\$ 322$, Telchac Composite Type, Tamay Ceramtc Complex, CPCRU 5

b. 'Dzib1lchaltun, Specimen \$1234, Telchac Composite Type, Copo 1 or 2 Ceramtc Complex, CPCRU 1.

F1gure 36. Fine Gray Ware, Chablekal Ceramlc Group. Palenque, Spec1men 非8, Cholul Fluted Type, Balunte Ceramic Complex, unplaced in CPCRUs.

Figure 37. Early Fine Orange Ware. Calatrava, Specimen 229 , unnamed Classic style polychrome, Naab Ceramic Complex, CPCRU 2. 
List of Figures (cont'd) - 9 -

F1gure 38. Fine Orange Ware, Altar Ceramle Group

a. Arenitas, Specimen $\# 231$

b. Trinidad, Specimen \#273.

a, b. Altar Orange Type, Jonuta horfzon, CPCRD 2.

F1gure 39. Flne Orange Ware, Altar Ceramic Group

a. Calatrava, Specimen $\$ 228$, Jonuta horizon

b. Tortuguero, Specimen \$46

c. Palenque, Specimen $\$ 246$, Balunte Ceramic Complex

a-c. Altar Orange Type, CPCRO 5.

F1gure 40. Fine Orange Ware, Altar Ceramic Group. Pledras Negras, Spec1men 317 , Altar Orange Type, Post-Tamay horizon, CPCRU 4.

F1gure 41. Fine Orange Ware, Altar Ceramic Group. Pledras Negras, Specimen $\$ 219$, Pabellon Modeled-carved Type, Post-Tamay hor1zon, CPCRU 3 .

Figure 42. Fine Orange Ware, Altar Ceramic Group.

a. Calatrava, Specimen \$226, Tumba Black-on-orange Type, Jonuta horizon

b. Palenque, Spec1men $\$ 66$, Trapiche Incised Type, Balunte Ceramic Complex.

a, b. CPCRU 5 .

F1gure 43. Fine Gray Ware, Tres Naclones Ceramlc Group. Palenque, Specimen $\# 247$, Tres Naciones Gray Type, Balunte Ceramic Complex, CPCRD 5.

Figure 44. Fine Orange Ware, Balancan Ceramic Group. a, b. Pledras negras, Provincla Plano-rellef Type, Post-Tamay horizon, 
List of Figures (cont'd) - 10 -

F1gure 44 unplaced in CPCRUs.

(cont'd)

a. Specimen $\$ 218$
b. Specimen $\mid 217$ After Butler (1935: P1. $4,8, \underline{3}$ ).

F1gure 45 Fine Orange Ware, Balancan Ceramic Group. Calatrava, Specimen 非10, Provincla Plano-rellef Type, Jonuta horlzon, CPCRU 5.

F1gure 46. Fine Orange Ware (a), Balancan Ceramlc Group.

a. Calatrava, Spectmen \#225, Provincla Plano-relief Type, Jonuta hor1zon, CPCRU 5

b. Tortuguero, Specimen 147, Provinc1a Plano-rellef Type, Tortuguero compositional group.

F1gure 47. FIne Orange Ware, Balancan Cerantc Group. Palenque, Spec1men \#57, Provincla Plano-rellef Type, Balunte Ceramic COmplex, CPCRD 1.

F1gure 48. Flne Orange Ware, unnamed composite type. Campeche (?), Specimen \#1239. Black-on-orange (compare Tumba Type); Incised design compares closely to Flgure 47 (Provincia Plano-rellef Type, Palenque), which also is in CPCRU 1.

F1gure 49. Flne Orange Ware, S1lho Ceramlc Group. a, b. Palenque, Yalton Black-on-orange Type, Terminal Class1c to Early Postclassic, CPC̣RU 1.

a. Spec1men $\$ 54$

b. Spec1men \#81.

F1gure 50. Fine Orange Ware, S1lho Ceramlc Group. a, b. Trinidad, Pocboc Gouged-1nc1sed Type, Terminal Classic to Early Postclassic. 
List of Figures (cont'd) $(11)$

F1gure 50

(con't'd)

a. Specimen 271 , unplaced in CPCRUs

b. Specimen $\$ 272$, CPCRU 2 .

F1gure 51. Flne Orange Ware, S1lho Ceramlc Group. Baf10, Specimen

\#1231, Pocboc Gouged-1nc1sed Type, Terminal Classic to Early Postclassic, unplaced in CPCRUs.

Figure 52. F1ne Orange Ware, Mat1llas Ceramic Group. Calatrava, Spec1men 168, Mat11las Orange Type, Late Postclassic, CPCRO 5.

F1gure 53. Fine Orange Ware, Mat1llas Ceramic Group. San Jose del R10, Specimen \#880, V111ahermosa Incised Type; Late Postclassic, unplaced in CPCRUs

F1gure 54. F1ne Orange Ware F1gurine. Calatrava, Spec1men $\$ 270$, Jonuta hor1zon, CPCRU 5. 
Table 1. Complete sumary of the composition of all the samples analyzed in the study.

Table 2. Q-mode Scaled Varlmax Factor Scores

Table 3. R-mode Factor Communality Estimates

Table 4. Standardized Discriminant Function Coefficlents for Chemical Paste Compositional Reference Units

Table 5. Standardized Discriminant Function Coefficlents for Paste Compositional Reference Units

Table 6. Standardized Discriminant Function Coefficlents for Mayan Fine Orange-Fine Gray and Other Fine Paste Pottery

Table 7. Specimens from the Maya Area Considered in this Study Miscellaneous Symbol Explanation

(Illustration) "Fig." refers to this publication, other cltations to Sayre, Chan and Sabloff(1971)

M1ss. Not Included in clustering run

+ (SPSS) Spec1men added to unit as result of high probability group containment as determined by SPSS during group formation stage

- (SPSS) Specimen deleted from unit as a result of low probability of group contalnment as determined by SPSS during group formation stage 
List of Tables (cont'd) - 2 -

() (Profected Membersh1p) Projected group membersh1p shown for CPCRUs and PCRUs. Number represents the projected group. Number in parentheses indicated 20 percent or less probablltty of group contalnment

- (Ceramic Group, Ceramic Type) No assignment

* (Ceramic Group, Ceramtc Type) Doubtful typological Identification

Table 8. Typology and Compositlonal Grouplings

* Indicates spectmens with doubtful typological 1dentification

Table 9. Petrographic Varlables

+ (Micaceous Matrlx or Volcanic Dust) Sample contalns greater amounts than Usumacinta, PCRU 2

- (Micaceous Matrix or Volcanlc Dust) Sample conta1ns less amounts of Usumacinta, PCRU 2

- (Ceramic Group, Ceramic Type) No typological Identification

Table 10. Provenlence of Maya Profect Specimens by CPCRU

Table 11. Provenience of Maya Project Specimens by Modifled CPCRU Note: Totals differ from Table 10 and subsequent tables due to addition to CPCRUs of elght unplaced specimens that fall within a group's 95 percent confidence interval. See Table 7.7 of Chapter 3 .

Table 12. Provenlence of Maya Profect Specimens by CPCRU and Ceramic Group 
List of Tables' (cont'd) - $3-$

Table 13. Provenlence of Maya Project Specimens by CPCRU and Ceramlc Type

Table 14. Proventence of Comblned Altar and Balancan Ceramtc Groups by CPCRO

Table 15. Provenfence of Combined Altar, Balancan and Tres Naciones Ceramic Groups: Ch1-Square Probab1l1ties 
Introduction:

A Brief Informal History of the Brookhaven

Fine Paste Ceramics Project

by

Jeremy A. Sabloff 
The Brookhaven Fine Paste Ceramics Project has spanned a 20-year perfod under the direction of Edward V. Sayre, Garman Harbottle and their many assoclates in the Department of Chemistry, Brookhaven National Laboratory. Under the ausplces of the U. S. Atomlc Energy Commission, these scientists have spent a huge amount of time collaborating with archaeologists in the study of Fine Paste ceramics.

The Brookhaven Laboratorles first began theli work with Fine Paste pottery in 1956 when Dr. Inton Satterthwaite of the University of Pennsylvania gave them some sherds from the great Classic Maya site of Pledras Negras in the southern Maya lowlands and from the highland Guatemala (Eee Fifilea I farthe Inciation of all the arshaeological sites montived in this monograph) site of Kixpek/. Dr. Sayre and his colleagues wished to test the newly developed technique of neutron activation, and the temperless pottery of Southern Mesoamerica which appeared fust prtor to the collapse of Classic Maya civilization. Their analyses polnted to an identity between the Fine Orange pottery from Pledras Negras and KIxpek. Moreover, it Indicated that the Pledras Negras Fine Orange differed from utilitarian potcery found at that site. Sayre and his co-authors concluded (Sayre, Murrenhoff, and We1ck 1958:111):

A group of Mayan sherdy frum Guatemala lnaluded pieces typical of the Mayan city of Piedras Negras and some typical of a spectal "fine orange" ware produced in the distant Guatemalan highlands. Examples of "fine orange" ware found at Pledras Negras were to be compared to both . . . Al1 the Mayan "fine orange" ware found at Pledras Negras more closely resembled in composition as well as in style its prototype from the mountains than the typical ware of that city, and hence probably had been transported from the mountains to the clty. Thus it was demonstrated that the data obtained might indicate provenance and reveal routes of anclent commerce.

In the late $1950^{\prime} \mathrm{s}$, Gordon R. Willey initlated the Peabody Museum's Rio Pasion archaeological project at Altar de Sacrificios: Work 
at this important site was followed by investigations at the equally significant site of Selbal. Both sites revealed relatively large quantities of Fine Paste ceramics, which figured prominently in the ceramic analyses and Interpretations of R.E.W. Adams (1971) and J. A. Sabloff (1975) at Altar and Selbal, respectlvely. There were strong Indications, based in part on the previous work of R.E. Smith (1958) and Helnrich Berlin (1956), that the Gulf Coast region of modern-day Tabasco and Campeche might be the source area for much of the Fine Paste pottery found at the Pasion sites. Moreover, there were clear Indications that the introduction of these ceramics at varfous southern Maya lowland sites might be related to the whole question of the collapse of classic Maya civilization.

It was with some surprise, therefore, that Sabloff read in an article in Sclence by Rainey, and Ralph (1966: 1491) that

The Brookhaven National Laboratory has used neutronactivation analysis to demonstrate, with pottery from Italy and from Central America, that a detailed analysis of elements contained in the clays makes it possible to determine the source of the materlals and perhaps the region of manufacture. For example, the fine orange ware found at Pledras Negras in the lowlands of Guatemala has been proved to have been fabricated from depostts located in the highlands.

He discussed this finding with G. R. Willey and R. E. Smith and in June, 1966, Willey wrote to Edward Sayre at the Brookhaven Laboratory. W1lley noted:

Since 1958 I have been excavating in Maya archaeological sites in the southern Peten. We have found numerous large quantities of Fine Orange at Altar de Sacrificios which is located at the junction of the Salinas and Pasion rivers in the southwestern Peten. More recently, we have found fine paste wares at Selbal in the southern central Peten. As you may know, these 
wares appear rather suddenly in Maya sites at the end of the Classic period (ca. A.D. 800-900). We are very much interested in pinning down the point of origin and difussion of these wares. I am still unconvinced that they do originate in the Highlands. For one thing they are found in their largest known quantities in the Tabasco Lowlands well downstream from us. In any event, it is an Important problem for us in Maya archaeology.

We have a very large sample of Floe Orange from Altar de Sacrifictos and a substantial sample from Selbal is now belng shipped up from Guatemala. Could we interest you in coming to our afd on this?

Sayre responded:

The posslbility of making a detalled technical study of Mayan Fine Orange is most Interesting to me. The small study undertaken in cooperation with Professor Satterthwalte. some years ago, of course, did little more than estedilish that compusiliutid luvestigation was a promising method for this material. What would now seem most worthwhile would be a comprehensive investigation of this pottery type.

Within six months, the Fine Paste Project was fully underway:

In early 1967, Dr. L.-H. Chan, a post-doctoral fellow at Brookhaven, began the first neutron activation analyses of pottery from Selbal, Altar de Sacrificios, and other Mayan sites. The orlginal alms of these analyses, as stated in a letter from Sabloff to Chan, Included the followIng:

1. was the Altar (Y) Hine (Irange pottery made at one place or a number of places? Sherds from Seibal, Altar de Sacrificios, and several other sites (collections of which are located in the Peabody Museum) could be tested and the results compared with the data which you already have from Pledras Negras and K1xpek.

2. was the pottery of the different Fine Orange Groups $(X, Y$, and $Z)$ made at the same place?

3. Is there any difference between the fancy burfal pottery (widespread) and the utilitarian pottery (Rto Paston area only) in source, composition, etc."

The Sayre-Chan work resulted in a paper presented at the 1968 
American Chemical Soclety Symposium on Archaeological Chemtstry. This report subsequently was published in Brill, edftor; Sclence and Archaeology (19.71) along with an accompanying comentary by Sabloff on the archaeological Implications of the Sayre-Chan study.

The preliminary results of the Brookhaven-Peabody collaboration were so intriguing, as regards the potentlal source connections among Fine Paste sherds, that it was decided to continue the Fine Paste analyses. As 1t was noted in the final Seibal ceramic report (Sabloff 1975: 242):

Fow more than half a dozen years, the Selbal Archaeological Project and the Brookhaven National Laboratory have cooperated in a ploneering study of the Fine Paste ceramics of Southern Mesoamerlca. The study was initiated for the purpose of testing a wide variety of assumptions which had been made by archaeologists about this pottery. In relation to Selbal and Altar de Sacrificlos, we were particularly interested in discovering if all the pottery was traded in or if some of it, especially the so-called utilitarian pottery of Altar de Sacrificlos, was locally manufactured. The initial results of the Brookhaven analys is indicated that virgually all the " $Y$ " or Altar group Fine Orange pottery was made in one place. Furthermore, although this location probably was not at either seibal or Altar de Sacrificio, it may have been somewhere along the Usumacinta drainage. In addition, the Altar Group material could be analytically separated from the Silho ("X") and Balancan (" $Z$ ") group pottery.

We were sufficiently excited and encouraged by these results to continue and to widen the original study.

W1 th the departure of Chan from Brookhaven, new associates of Sayre such as P. Melfers and later Rafael Abascal jolned the project. Additional sherds from Maya sites were sent to Brookhaven over the next several years in order to expand the original study. Moreover, In 1969 , three important events occurred which had a profound effect on the Brookhaven Fine Paste Profect. First, while Sayre went off to Egypt on leave, Garman Harbottle of the Department of Chemfstry at 
Brookhaven agreed to take over the Fine Paste analyses. Harbottle's continuing enthusiasm for the project was in no small measure responsible for Its success. Second, Robert Rands of Southern Illinols UnIvers1ty became Interested in the project and agreed to send Fine Paste materlals, which already had undergone petrographic analyses to Brookhaven for study. It thus became possible to fruftfully comblne the results of neutron activation and petrographic analyses in the Fine Paste study. Third, Initial soll samples from the Usumacinta drainage were sent to Brookhaven through the cooperation of Edward Sisson so that it became possible to begin the search for potentlal source locations for Fine Paste pottery. In addition, through the cooperation of Michael Coe, John Paddock, and George Cowg111, samples of fine, temperless pottery from San Lorenzo In Tabasco, Lambityeco in Oaxaca, and Teotihuacan In Central Mexico were submitted to Brookhaven for comparative analyses.

In 1975, Harbottle and Sayre published the Interim results of the "Brookhaven-Peabody phase" of the Fine Paste study in an article entitled "Current Status of Examination of Sherds of Fine Paste Ceramics from Altar de Sacrificios and Seibal and their Comparison with other Maya Fine Paste Ceramics." But several years before this publication, the focus of the Brookhaven study had begun to shift. Since the early 1970's, the collaboration between Brookhaven and Southern I1l1nols Unlversity has grown in 1mportance. The analysis of a wide variety of Fine Paste sherds from the Palenque region, as well as clay samples, has considerably broadened the base of the initial study. The petrographic analyses of Rands and his associates also have glven the Fine Paste study a new dimension by providing complementary data and allowing better and finer divistons of similar Fine 
Paste sherds than was previously posstble. With the entrance of Ronald L. Btshop of Southern Illinois University in the profect, the "Brookhaven-SIU phase" has proceeded rapidly and has recently been completed.

The papers in this volume repiesent the culmination of two decades of research. They Indicate the great potential of analytical studies of archaeological ceramics and the value of close cooperation between scientists and archaeologists to the benefit of the research and scientific goals of both parties. 
$-8-$

CHAPTER TWO

\author{
Chemical and Mathematical \\ Procedures Employed in the \\ Mayan Fine Paste \\ Ceramics Project
}

by

Rónald L. Blshop, Garman Harbottle, and Edward V. Sayre 
$A \rightarrow \quad: \quad$ The Chemical Analysis of Mayan Fine-paste Ceramics

$B \rightarrow \quad \therefore \quad$ Introduction

It is interesting that the.first chemical analyses of archaeological material, which were carried out by Klaproth (Caley 1962) in 1790, were concerned with a technical point: the means by which the colors of red, green, and blue glass tesserae, from a mosaic in the Villa of Tiberius at Capri, were produced. A century later, Richards at Harvard (Richards 1895) analyzed classic Greek pottery, but with an entirely different alm, the same one that will be our concern in this paper, namely, the determination of probable provenience. "At the request of Mr. Edward Robinson, of the Boston Museum of Fine Arts, several analyses of ancient Athenian pottery were recently made at this laburatury... Lhe Interest of these analyses was mainly archaeological, turning upon the identity of the source of these remains with that of others found in other cities,..." and finally "The variations in the relative amounts are singularly small, the range being not nearly so large as that given by Brougniart, in his 'Traite des Arts Ceramiques'. Hence, It is possible, that all of these specimens, which were picked up In the city of Athens itself, were the product of a local pottery." Almost hidden in Richards' statement is an assumption that has elsewhere been called the "Provenience Postulate" (Weigand et al. 1977) namely, that in many instances there will exist differences 
in chemical composition between pottery from different sources that will exceed, in some recognizable way, the differences observed within pottery from a given source. This postulate is at the root of all studies involving provenlence attribution via chemical analysis: the first part of this section will deal with the measurement of these chemical composition differences, and the second, with the wathematical and statistical procedures for "recognizing" them.

In $1955^{\circ}$ studies on the analysis of ancient pottery via neutron activation (abbreviation, NAA) were begun at brookhaven National Laboratoryo the first samples of Mesoamerican ceramics were supplied by Professor L. Satterthwaite and included "Fine Orange" ware (Sayre et al. 1958). This may properly be taken as the starting-point of the research path which terminates, at least for the time being, in the present volume $\odot$ signtficant milestones on this path were the initiation of collaboration with G. Willey and J. Sabloff at Harvard University-The Peabody Museum, then with R. Rands at Southern. Illinois University, and the generous assistance of J. Paddock in Oaxaca, P. Krotser in Vera Cruz and M. Coe at Yale. Publications thus far include the Papers of the Fourch Sympostum on Archaeological Chemistry of the American Chemical Society (September, 1968) published under the editorship of Brill (1971), the Peabody Museum Memolr of 1975 (Sabloff 1975) containing an interim report, In the appendix, by Harbottle and Sayre, and the paper delivered at the XII Congreso de Americanistas (Rands et al. 1975) which is a very short sumary of the Mayan Fine Paste Studies, touching on 
the present work. The present volume should be consfdered as superceding all these previous studles, at least insofar as the analyses of Fine Orance ware are concerned (see Table 1 for a complete sumary of the composition of all the samples analyzed in this study; the CPRU's are discussed in Chapter 3 ).

\section{Sampling of Archaeological Ceramics}

In his Ph.D. thesis, Bishop (1975) has considered an archaeological ceramlc as a kind of "spectal sedimentary product"if and he and Rands will, In Chapter 3 below, discuss the geochemical, petrographic and sedimentological implications of this view in the context of the Fine Paste wares. The procedures to be adopted in the sampling of Fine Orange wares are also very much dependent upon these same considerations.

If we think of the content or percentage of a particular chemical element, let us say fron, in clay from a bed which has been repeatedly used for the preparation of a certain type of pottery, then it is clear that different samples of the clay, and hence different samples of pottery, would show, even if analyzed exactly, a natural "spread". We can express that spread mathematically as a variance, $\sigma_{N}{ }^{2}$, where $\sigma_{N}$ is the standard devlation of the exact percent iron measurements in the assumed infinfte population of clay or ceramic samples. Note that we imply that iron is nelther galned nor lost during the fabrication, firing and burlal period of an archaeological ceramic specimen: although this 1s probably true for most elements, it may not be for all, as w1ll be discussed below. 
The statistical parameters that will define the properties of a particular group of ceramic specimens, in terms of which group membership will be defined, are the centrold of the group and the group variance about this centroid. For individual elements the analytically determined total variançes, $\mathrm{S}_{\mathrm{T}}{ }^{2}$, will be greater than the measured natural variance of the group itself, $s_{N}{ }^{2}$, by the sum of the additional variances, $\mathrm{s}_{S}{ }^{2}$ and $\mathrm{s}_{\mathrm{A}}{ }^{2}$, added respectively by the errors in the sampling and the analyses of 1ndividual specimens. That is

$$
\mathrm{s}_{\mathrm{i}}^{2}=\mathrm{s}_{\mathrm{N}}^{2}+\mathrm{s}_{\mathrm{S}}^{2}+\mathrm{s}_{\mathrm{A}}^{2}
$$

Thus if the measured $\mathrm{S}_{\mathrm{T}}{ }^{2}$ is reasonably to represent the natural $\mathrm{s}_{\mathrm{N}}{ }^{2}$, the variance of sampling, $\mathrm{s}_{S}{ }^{2}$, and of analysis, $\mathrm{s}_{\mathrm{A}}{ }^{2}$, must be kept within reasonably low limits. The combined errors of sampling and analysis can be inferred from the reproducibility of sets of multiplet analyses of samples taken from the same objects, and the analytical error itself determined by multiplet runs of samples of carefully homogenized materlals. Within limits the analytical error can be reduced to an arbltrarily determined amount through refinement of the analytical procedure and the sampling error is similarly subject to reduction through in effect using greater fractions of the individual specimens in each sample. It is very important, however, that both sources of error be taken Into account and reduced to acceptable limfts chrough appropriate control of sampling and analytical techniques. 
The question "To what degree will the pottery from a given source be consistent in composition?" inyolves both the geochemfcal distributions mentioned above and the anthropological tradition of pottery-making. If the potter was making tempered wares, then pottery analysis by any technique necessarily reflects the elemental contents of the temper as well as the clay. Some tempers, notably quartz sand (silica), have low specific contents of trace elements, and tend to act merely as diluents. Organic tempers such as straw or cattail fluff would be expected to burn out on firing, leaving behind their mineral ash, which one would guess would not seriously perturb the analytical data relationships between clay and ceramic. On the other hand, tempers such as voleanic ash contain enough different elements to contribute materially to the overall composition (cf. Rice 1978; Arnold et al. 1978). In any case, the possibllity of forming archaeologically viable groups of tempered sherds on the basis of their chemical compositions rests on the conservatism of pottery-making societies: the potters tend to obtain temper and clay by following traditional patterns and to mix them according to pragmatic recipes or proportions handed down in their societies. Such seems to have been the case in the highly-tempered "Thin Orange" ware associated with classic Teotihuacan: we have recently: completed a chemical study of this trade ware (Sayre and Harbottle nd.; Abascal-M 1974): suffice it to say here that although the "core" group of Thin Orange was somewhat more diffuse (chemically speaking) 
than fine-paste groups we have studied, it was nonetheless sufficiently cohesive to allow it to be differentiated from all other pottery of Mesoamerica, and especially from (presumed) local imitations. Another case in point concerns the mica-tempered amphorae of Marseilles (Fillieres 1978). Here, although the ware 1s highlytempered, the body of 95 analyses form an astonishingly cohesive group, reflecting either an exact ceramic technology, or the fortunate occurrence of a remarkably homogeneous naturally-tempered clay.

In the present work we are, fortunately, dealing with fine-paste, i.e. not deliberately tempered, wares. There is good reason to expect that the compositon of this pottery will relate closely to that of the clay out of which it was formed, and also that small samples of these sherds will be representative of them. We have noticed, for example, that whereas in the case of tempered "Thin Orange", It was necessary to grind up and mix two to three grams of each sample and from this withdraw a representative specimen of 40 mg for analysis (Abascal-M 1974; Harbottle et al. 1976), in the case of Fine Orange, small repetitive samples taken from a single sherd agreed very well. In fact, in one case we analyzed a single 6-mg sample drilled from a Fine Orange sherd and found that its analysis agreed well with a much larger sample taken from the same sherd. This observation, that fine paste wares tend to be more uniform chemically, was also borne out in our recent study of some Greek pottery (Bieber et al. 1976a, and b) and by other studies of "Nile mud" wares (Perlman and Asaro 1969). Additional data on the variation of elementary concentration on replicate sampling will be found in Bieber, Jr. (1977). 
However, if we wish to relate fine paste wares by their chemical compositions to existing clay sources, one further difficulty enters. The pottery-maker may, in preparing his clay, have levigated it to remove coarse extraneous material to yield a working clay with improved properties, for example, elasticity. We were concerned that the coarse and fine fractions of a single clay might differ in their chemtcal makeup, and therefora devised a. routine procedure for separating clay into such fractions (actually; clay as received, and a fine fraction). On the basis of many such paired analyses we find, with a few exceptions, that clays as received, and fine fractions of them, tend to be very similar chemfcally. In cluster analysis (see below) the paired fractions often come out together. Attas et al. (1977), however, working with clays from Central Greece, found substantial changes in composition in the levigated fraction, as we have observed in a few cases. We feel that these analyses, giving us an idea of the magnitude of change in pattern due to levigation, are important in cases where we wish to relate archaeological ceramics to modern clays.

In the laboratory, we employed the following routine procedures, in connection with sampling;

i) A full description of the specimen, its provenience, source, excavation data, field numbers etc. were recorded, and a photograph taken for reference. A Brookhaven number was assigned. 
1i) The outer layer of the edge of the sherd or an inconspicuous spot on the surface of a whole vessel were ground away, using a tungsten carbide motor-driven burr.

iii) The sherd or vessel was then drilled in the cleaned spot using a solid tungsten carbide drill bit. The powder was collected on a clean weighing paper. If possible, the sherd was drilled at several points to provide a more representative, combined sample. At all points an effort was made to sample the interior portion of the sherd body.

iv) Sherds too small or too thin to drill were prepared by grinding off all the outer surface with the burr, then crushing the whole remainder in an agate mortar. In general, 100-200 mg of powder were sought:

v) Clays, as mentioned above, were analyzed "as received", and "levigated": The dry clays were crushed and mixed in an agate mortar. The levigation consisted in mixing 5 gms of clay with 40 ml of distilled water in a mixing cylinder, with vigorous shaking for $4 \mathrm{hr}$. The suspension was then allowed to stand for $2 \mathrm{~min}$, at the end of which time the supernatant, containing the fine fraction, was poured off and allowed to dry at room temperature.

vi) Both sherd and clay samples were finally dried for 18 hours at $110^{\circ} \mathrm{C}$. There is no question that clay dried in this fashion will still contain a few percent more water than fired ceramics of the clay identically dried. This will necessarily introduce a small overall concentration difference which can, however, be 
easily compensated mathematically since the water acts as a pure diluent. In other research (Brooks et a1., 1975) we have shown that firing under various conditions of time and temperature does not cause loss of the elements being determined. Attas et al. (1977) also found little or no effect of firing temperature. These results are also in agreement wilh a recent extensive study of pottery-making villages in Guatemala where questions concerning culturally influenced variability of trace elements in pottery were examined (Rice 1978). Our preferred method at the present date is to form briquettes out of clay to be analyzed, to fire these and then treat them exactly as pottery.

Packaging for Bombardment

About $40 \mathrm{mg}$ of each dried sample was weighed to the nearest $0.01 \mathrm{mg}$ into a quartz ampoule: these ampoules were prepared from ultra-high purity Suprasil $T-202 \mathrm{~mm}$ 1.d. fused quartz tubing (U.S. Fused Quartz Company) by sealing at one end, boiling in aqua regia, rinsing with distilled water and drying. After weighing in the sample, the quartz ampoule was sealed off in vacuo and labeled with India ink. Empty labeled ampoules were also Included with each run as a check on the purity of the silica and ink. Sealed ampoules are never couched except with tweezers or cotton gloves after cleaning and before bombardment. 
Two reactor neutron irradiations, for a short and a long exposure period, were performed on all samples (see $=$ below): for the short irradiation the ampoules were placed in a plastic "rabbit" which could be moved into the active zone of the reactor. For long irradiations, the group of ampoules were first sealed into an envelope of ordinary quartz, which then entered the reactor in an irradiation can.

\section{Standardization}

Although in principle one could calculate concentratluus of elements observalle in NAA from a knowledge of integrated flux, neutron capture cross-sections etc. it is almost universal practice Instead to include standards with the unknown samples being bombarded. If one knows accurately the concentrations of elements in the standard, then the concentration of the same elements in the unknown may be established through simple ratios of the recorded signals of the radiations representing the different radioisotopes in the standard and unknown. As standards we employ all six U.S.G.S. analyzed rocks: they are designated AGV-1, BCR-1, DTS-1, PCC-1, G3P-1 and G.2: Eamplas of these rnrks have been analyzed by many laboratories (Flanagan 1967., 1969, 1973, 1976) and at Brookhaven we have prepared a table of "best values" using Chauvenet's Criterion to reject extreme values (fable I Abascal et al. 1974). The concentrations appearing in this Table are those adopted for standardization in the present research, except for $\mathrm{La}_{2} \mathrm{O}_{3}$, where we have 
taken $\mathrm{AGV}-1=42.5, \mathrm{BCR}-1=29.6, \mathrm{GSP}-1=244.4$, and $\mathrm{G}-2=108.0 \mathrm{ppm}$.

Although these "new" Lanthanum values change the calculated concentration of that element by about $8 \%$, they have no more than $1 / 2 \%$ effect on the mean Euclidean distance (see below) which is a basis for cluster analysis.

Not every standard rock is used to calibrate every element. Our choice, and the rational therefore, are given in Bieber et al. 1976a. Our practice 1s to weigh out, dry, encapsulate, bombard and count the rock standards together with each group of ceramics. and clay samples. In the event that other investigators wish to compare their analyses with ours, the best results would be achieved by their employing the same rock standard. 'Some archaeometric laboratories are, however, at present employing the Asaro-Perlman pottery standard (Perlman and Asaro 1969). We have comparcd the Așaro-Perlman standard to the mean values of the USGS Rock standards using our normal analytical procedures and also recently have compared the results of a large number of analyses of "Nile Mud" ware in this laboratory - to comparable results obtained by Permlan and Asaro (1969) on a different set of samplès of the same ware. In general, agreement was good, but could be improved by adjusting their data to our standardization. This suggests that data obtained using the Perlman-Asaro standard may readily be converted to data quite compatible with our data bank, in other areas of the world as well, specifically, with other analyses of Mayan sherds. We plan to publish in the near future a note which will include the numbers appropriate for making this transformation. 
Bombardment with Neutrons

Because the many radioisotopes activated by neutrons in pottery decay with a variety of half-lives, it is necessary to perform at least two bombardments, one of short and one of long duration. Both were, in general; carried out at the Brookhaven High Flux Beam Reactor. Short and long bombardments followed two distlnct procedures:

i) A Inng, activation was made for 3.5 hours in the core postition at fluxes up to $5 \times 10^{14}$ neutrons $/ \mathrm{cm}^{2} \mathrm{sec}$ to activate the long-1ived elements. Then, after 8 or 9 days, during which the intense activity of the short-lived elements died down, the latter were re-activatcd by a short bombardment of 1 min at a flux of $1 \times 10^{4} \mathrm{n} / \mathrm{cn}^{2} \mathrm{sec}$ (position V-11). The samples were then cooled 2-5 hours, loaded into a samplechanger connnected to the germanium counter, and counted twice. The first count, of short duration (typically 400 seconds) measured manganese-56 and sodium-24 and the second, of 4000 seconds, the remainder of the radioelements, including better values for sodium-24.

ii) The second procedure 1nverted the urdes, the short bomberdmant being first and the long bombardment second (Abascal et al. 1974) with separate countings following each bombardment. Each procedure has advantages and disadvantages of a technical nature, which need not be discussed here.

\section{Counting}

The counter and data-recording procedures have not changed (Abascal et al. 1974; Sabloff. 1975; Hammond et al. 1976) recently and will be only briefly summarized here. The detector 
fed samples by a 48-position sample-changer (Atomic Development and Machine Co.), was a Princeton Gammatech $7 \%$ Ge-Li crystal of $1.82 \mathrm{keV}$ resolution on cobalt-60. The pulses from this detector were amplified (Ortec 472) and fed to a Nuclear Data 2400 4096channel pulse height analyzer modified to record not only the gamma spectrum but elapsed time, spectrum tagword and date as well on a magnetic tape. Dead time was corrected by means of a special, locally-designed, all-solid-state pulser. Reliable peak values are obtained for the elements. $\mathrm{Na}, \mathrm{K}, \mathrm{Rb}, \mathrm{Cs}, \mathrm{Ba}, \mathrm{Sc}, \mathrm{La}, \mathrm{Ce}, \mathrm{Eu}, \mathrm{Lu}$, Hf, $\mathrm{Th}, \mathrm{Ta}, \mathrm{Cr}, \mathrm{Mn}, \mathrm{Fe}, \mathrm{Co}, \mathrm{Sb}, \mathrm{Sm}, \mathrm{Yb}$, and $\mathrm{Ca}$. However, calcium, and titanium as well, are better analyzed by $X$-ray. fluorescence than by NAA (see below). Although in principle a few more elements could have been determined, a substantially greater expenditure of time and effort would have been required for this. It should be noted here, as has already been mentioned above, _ _ - . that Mesoamerican and other archaeological ceramics have been analyzed in this laboratory for nearly 25 years. This period has witnessed a steady development in sensitivity, precision and ease of operation with the result that some materlals analyzed early on could be reanalyzed in the period 1972-73 to take advantage of improved methods. All the analytical data listed in Table $\frac{1}{X}$ is thus on a common basts, internally intercomparable and externally also capable of comparison with our entire data bank. In Table 1 some entries are mlssing: these cases reflect occaslonal technical 
difficulties, or, stages in the development and improvement of methodology. We do not feel that this missing data can in any way compromise the validity of our conclusions.

\section{$\therefore \quad$ Preliminary Data Processing}

The raw gamma spectra are analyzed by the program BRUTAL (Gunnink et al. 1967) which yields intensities of the gamma rays corrected for background and sample weight. The output cards from BRUTAL form the input to our locally developed programs ELCALC and SMPCALC wich apply decay and dead-time correctlons, calculate calibration coefficlents, average them, and ultimately calculate and punch out the analytical data for each sample. These sample data cards (two per sample, format and coding available on request) contain space for up to 36 elements, reported as element oxtdes (Abascal et al. 1974).

\section{$\because$ Analysis by X-ray Fluorescence}

To determine the elements calcium and titanium we employed $\mathrm{X}$-ray fluorescence. The instrument was a Siemens, and the $\mathrm{X}$-rays emerged from a chromilum target. The six U.S.G.S, ruck studuaids described above were also employed here: quite satisfactory calibration was achieved when the "best values" of Flanagan (1969: Table 4/109) were employed. 
$B \rightarrow \quad$ Petrographic Examination

One of the unusual features of this investigation, already partially reported (Rands et al. 1975:534) was the correlation of petrographic and chemical data obtained for the fine-paste Mayan ceramics (see Chapter The petrographic examinations, carried out by Paul B. Benson and Pei-yuan Chen, employed boch blnocular and thin-section techniques. Paste color and selected petrographic variables such as mica, feldspar, volcanic dust and opal phytoliths were scored for all sherds and provided important information in the final grouping and provenience attribution of ceramics.

\section{The Formation of Archaeological Ceramic Groups}

Introduction

All avallable information, chemical and petrographic analyses, ceramic paste type, form, decoration, and archaeological context should eventually be considered in the assignment of pottery specimens to groups which in accordance with the Provenience Postulate appear to have originated from common sources. This becomes increasingly Important when micro-regional variation is sought (cf. Bishop 1979). The present investigation is essentially confined to two wares, that is Mayan Fine Orange and Fine Gray and the clays out of which they might have been fabricated. To the extent that this restriction 
is conformed to, the task of classification is deflnitely simplified in that one would expect the number of sources to be limited to a relatively small subset of those from which all types of Mesoamer1can pottery stemed. However, even within this constellation of pottery the problem of statistical classification is sufficiently complex that a. progressive stepwise procedure was followed, in which one first attempted to classify the specimens upon chemical parameters alone and then to refine or confirm the groupings that had been established through consideration of petrographic and archaeological information.

\section{Data Transformations}

In several publications (. Sabloff $\because . . .1975$; Harbottle 1976; Sayre 1977) we have given the reasons. for the possible choice of a logarithmic transformation of our analytical data, namely, to give equal weight to a glven fractional change in elementary concentration, regardless of its absolute magnitude, in forming taxa, and to produce 1n-group distributions that closely approximate normality in accordance with the observation that elements quite often are distributed in nature not normally in concentration but lognormally. (or as Student's $t$ for small samples). One needs to meet this "normal distribution" requirement in order to calculate probability of group membership, through the calculation of the Mahalanobis distance (Mahalanobis 1936, Sneath and Sokal 1973, pp. 127 and 405, Cooley and Lohnes 1971, Hodson et al. 1971:62). Another procedure often employed 
standardizes the raw data without log transform by subtracting the mean value from every measurement of an element, and dividing by the standard deviation (Sokal and Rohlf 1969: $380 \mathrm{ff}$ ). We have, at various stages in our numerical taxonomy, used both log transform and raw-data standardization. As mentioned in other papers (Harbottle 1976; Bishop 1975; Al Kital et al. 1969; Krumbein and Graybill 1965: Table 5.4; Mason 1966:98) the question appears to be an upen one. In current research at Brookhaven we are studying the nature of these distributions, and hope to be able to present data soon relating to this question. At this point we can only state that there does not appear to be a clear-cut decision for either type of distribution, normal or lognormal.

\section{Cluster Analysis}

$\therefore \because: \because: \because \ldots \therefore$. We have found that the most convenient procedure in the cluster analysis of the Fine Paste data is not to include chemical, archaeological, and mineralogical variables in one great computer program, but to begin with chemical groups, then juxtapose the other, more or less independent data. This juxtaposition will be dealt with in Chapter 3, 'here we will deal solely with the chemical data.

Since we have already described our procedures at length (Harbottle 1977; Weigand et al. 1977; Bleber et al. 1976a; Sayre 1977; B1shop, Rands and Harbottle 1979) we will only sumartze them here. Several years of experience in applying various procedures of 
cluster analysis have caused us to appreciate the fact that if there are discrete (or "natural") groups present in our data set, most of the available clustering algorithims will recover them. However, when there are several subtle distinctions or divisions to be drawn, the choice of a particular clustering approach over another can have significant influence on the resulting partitions, (cf. Sneath and Sokal 1973; Everitt 1977). It cannot be stressed too strongly that there is no "cookbook" approach to data reduction. One must proceed in a manner that is compatible with the rcocarch goalo and employ all availablo data to ovaluate the chemical groups that are formed. Rigorous parametric statistical evaluation is not often possible due to the sampling design or small numbers of: samples comprising a compositional group. Therefore, in the end, having employed high computer technology, the final acceptance of a chemically. based ceramic group often must rely on pragmatic or common sense evaluation. With this in mind we will now discuss the procedures that were used in the present treatment of the Fine Orange-Fine Gray data.

We begin with a hyperspace of $n$ dimensions scaled off in the transformed coordinates described above. Each point in that hyperspace represents a particular set of $\mathrm{p}$ analytical concentrations, the total analysis we have made of one particular sample. A significant sourcegroup is then represented by a cluster of points in hyperspace: it is to discover these clusters that we carry out the cluster analysis. 
Clustering procedures may be glossed into two major categories (Lance and Williams 1967a, 1967b): hierarchical methods and 1terative partitioning. A hlerarchical agglomerative procedure begins with the calculation of a similarity or dissimilarity ("distance") matrix, giving a measure of chemical agreement between all possible sample pairs (Harbottle 1977:46-49). One hierarchical clustering procedure analyzes the distance matrix and joins the two entities which are nearest to each other. The matrix is then analyzed for the next two closest samples and the procedure is continued -.... (........... uatil all entities are joined into a single cluster. (Sneath and Sokal 1973:201) A usual method of representing the sample to sample relationships is in the form of a dendrogram. (Sneath and Sokal 1973:58) Sequential, agglomerative, hierarchical, non-overlapping cluster analysis was employed in the early stages of the Fine OrangeFine Gray project. However, for the present summarization we preferred to use an alternative partitioning approach for the initial formation of compositional groups.

Unlike the technique previously discussed, iterative partitioning procedures give no hierarchical relationship between resulting clusters nor is the initial group make-up final. Using the program CLUS (Rubin and Friedman 1967) the data matrix is searched for internal geometric evidence of the existence of groups. A partition of n-samples into g-groups is considered to be optimal when a selected criterion function is maximized. The function $T$ is calculted by the fundamental partition equation (W11ks 1962): 


$$
T=B+\dot{W}
$$

where $B$ is the pooled within-group matrix of welghted squares and cross products of devlations of group centrolds from the grand centroid; $W$ is the matrix of squares and cross products of the deviation of the samples from their respective group centroids. These two components sum to I which is the matrix of weighted squares and cross products of the deviations of the group centroids from the grand centroid. The elements of each of the matrices are given in Cooley and Lohnes (1971). We are searching for the number of groups that will contain the smallest amount of variation within the groups and the greatest amount of separation between the groups (this is the basic tenet of the Fisher F-test). If only a single variable were involved $T=W+B$ is a statement about scalers and since $\mathrm{T}$ is constant one need only to minimize $W$ in order to maximize $B$. For more than one variable, the equation refers to matrices and the racto of the macrix decermlnauls way be used to assign group membership. The $|T| /|W|$ is a generalized variance ratio which has the attractive properties of including the effects of the covariance within each group as well as the variable covariance across the total number of samples. In addition, the ratio is invariant under non-singular linear transformations of the original data (such as standardization), and does not assume that the groups within the data are spherical in nature--it does, however, assume that all the groups have a slmilar hyperdimensional shape (cf. Scott and Symons 1971; Everitt 1977). 
In brief, the Fine Orange-Fine Gray clustering was performed by CLUS starting with the raw chemical concentrations. These data were standardized and the elgenvectors were calculated, ten being retained as the new variables for clustering. An initial random partition into two groups was made and then iteratively evaluated by a series of sample reallocations until the "best" partition was obtalned as evaluated by the maximization of $\mid \mathrm{T}\} /|\mathrm{W}|$. The change in $108(\max (|\mathrm{T}|,|\mathrm{W}|))$ as the number of groups increased was used as an informal indicator of the number of "natural" groups contained in the data set (see Chapter 3, Figure 3 ).

Assessment and refinement of the trial groups formed by CLUS drew upon a battery of related techniques utilizing variable correlations and the heuristic use of multivariate statistics.

Single group evaluation: Mahalanobis $\mathrm{D}^{2}$

It has been known for some time (Harbottle 1970) that in some groups of archaeological ceramics two or more elements are correlated: correlation coefficients higher than 0.90 are frequently encountered (Brooks et al. 1974). Correlation of elements $A$ and $B$ in effect removes some of the value of the analytical information: if we have analyzed a sample for element $A$, then we also know; at least roughly, the concentration of element B. On the other hand, for a group of samples, the fact that $A$ and $B$. (and perhaps other) elements are correlated is itself useful knowledge, enabling us to distingulsh groups from one another. To return to the hyperspace of analytical data described in section $C$ above, we may see that uncorrelated groups would be (hyper) spherical, while correlated groups would be 
represented by stretched out ellipsoid (cigar shapes). The degree of correlation was determined in the Mayan fine-paste groups by calculating a correlation matrix -- i.e., the correlation coeffictent between all possible element pairs. When a group has been established, we may calculate the Mahalanobis (1936) distance $\mathrm{D}^{2}$ between each sample and the centroid of the group (Sneath and Sokal 1973:405): such distançes, for infinite multivarlate-normal distributions, are distributed as chi-squared. For smaller (randomly-drawn) populations, the probability of group membership may be calculated for any point in the hyperspace, including any sample-polnt, frum Hotellinga $T^{2}$, the multivariant equivalent of students $t$.

$\therefore$ Multiple groups: Discriminant Functions

With more than a single group under consideration the problem becomes one of discrimination and Involves the technique of linear discriminant analysis (Fisher 1936; Rao 1948). The original variables are weighted into new combinations that will best separate the groups under consideration. This new set of axes is usually fewer in number than the original number of variables; thus visual separation of the data points may be enhanced. The Mahalanobis distance between group centroids and the distance of any sample to its group centroid are calculated and the probability of group separation or sample Inclusion within a group is agaln evaluated by Hotelling's $\mathrm{T}^{2}$. 
Two differences between our use of a single group evaluation by $A D C O R R$ and multiple discriminant analysis require mention. ADCORR operates in a standardized $10 g$ concentration hyperspace and requires about a 3 to 1 ratio of samples to variables before there can be real confidence in the probability statements. It is, therefore; most useful for group evaluation where large numbers of analyses are ava1lable.

Discriminant analysis as performed by SPSS (Nie et al. 1975) operated in a standardized concentration space (although a $10 g$ transformation could have been performed as a prior step). Under SPSS Version 7, a pooled variance-covarlance matrix was used. That is, the group separations were viewed relative to a matrix calculated over all groups. This allowed for the evaluation of systems in which sume groups had only a few members. Both the programs ADCORR and SPSS are useful in testing and refining groups, and as such form links in an iterative chain leading to final groupings.

Q-mode. Factor. Analysis

Q-mode factor analysis is a multivariate technique which was employed to investigate the relationship among Fine Orange-Fine Gray and other, possibly related, pottery groups. While this technique has received fairly extensive application in geology (cf. Joreskog, Klovan, and Reyment 1976), it has been infrequently utilized in compositional characterization studies. Archaeometric 
applications include Blshop 1975; Rands et al. 1975; Bishop 1979; Veakis 1979).

Briefly, it requires that a sultable measure of similarity between the objects be chosen and then based on that measure, an $\mathrm{N}$ by $\mathrm{N}$ matrix is formed containing the degree of similarity pairwise among all $\mathrm{N}$ items. For the present investigation, the "index of proportional similarity" as proposed by Imbrie and Purdy (1962) was used. That is, the similarity between two row vectors is defined by the cosine of the angle between the vectors in the p-dimenstonal variable space. The $N$ by $N$ matrix is frequentiy quite large; thus, finding the rank of the matrix by elgen-analysis may provide a way of describing the sample relationships in fewer dimensions. This reduced rank matrix can be thought of as representing theoretical "end members" of which the samples are considered linear combinations. We also want to know the composition of the end members in terms of the orlglnal variates. According to Imbrfe (1963) these end members may have the most divergent compositions.

As stated above the end members are approximated by the "significant" elgenvalues. To assist in seeking end members that are fiaximally distinct in composition, a varimax rotation of the axes may be used. The relationship of the objects is then described relative to these new reference vectors. (The details of the actual procedure that was used may be found In Klovan and Imbrie 1971; B1shop and Veakis nd. present an overview of the technique with archaeological applications). 
This chapter has sumarized the analytical and mathematical procedures that have played a major role in the preparation of the present report. The discussion of statistical techniques employed in various stages of the data reduction has not been exhaustive in : that the fine paste data have also been considered from many other statistical perspectives.

We close by reiterating the need for purely chemical data to be supplemented by other types of information--petrographic, archaeological, etc. In the absence of such independent verification, it is doubtful if the splitters' 'view taken by Bishop and Rands (Chapter 3 ) could have been sustained on purely chemical grounds. The Maya Fine Orange-Fine Gray project well illustrates that an investigation into ceramic production zones must be truly multidisciplinary in nature if the archaeological potential is to be realized. 
1. The authors acknowledge with pleasure the continuing assistance of the High Flux Beam Reactor operating crew and

the fine technical assistance rendered by Mrs. Elaine Rowland,

This work was carried out under the auspices of the

U. S. Department of Energy. 
CHAPTER THREE

Mayan Fine Paste Ceramics:

A Compositional Perspective

by

Ronald L. Bishop and

Robert L. Rands 
this time a reasonably extensive chemical data base for fine paste pottery had been realized at the Brookhaven National Laboratory. The speed of the computer combined with the power of multivariate statistical techniques provided means of probing the relationships among chemical and petrographic data. Although general agreement was obtained between petrography and Brookhaven's provisionally recognized chemical gruups, petrographic heterogeneity was observed within the Fine Orange-Fine Gray section of the dendrogram (Rands et al. 1975: Fig. 2, $\underline{A-P}$ ). In view of current hypotheses regarding a single source of Filu Orange-Fine Gray ecramica, such heterogeneity indicated the need of additional sampling and numerical refinement. It was believed that petrographic data would serve to interpret and evaluate chemical patterns, the combination of the two approaches being more satisfactory for archaeological reconstruction than either considered in isolation (cf. Harbottle 1977: 64).

Not included in the paper cited above (Rands et al. 1975) were fine paste ceramics from Altar de Sacrificios and Seibal, which had previously been analyzed at Brookhaven National Laboratory. Subsequently, Bishop (1975) considered these materials along with fine paste pottery from sites on the Usumacinta River. The predominance of Pabellon Modeled-carved in one of his resulting groups was striking. Then-available petrographic data supported the chemically-derived groups.

Utilizing more sophisticated clustering procedures, Bishop (1976a) continued the Fine Orange-Fine Gray Investigation. Provisional chemical groupings were identified, having loci toward the Pasion and downstream on the Usumacinta. Petrographic patterning was indicated, although 
Ceramics included in the present investigation of Fine Orange and related wares reflect diversity in sampling. Typologically recognized units from the Maya Terminal Classic bear the thrust of the present investigation, although materials dating from earlier in the classic and from the Postclassic are represented. In addition, fine past pottery from outside the Maya area, which has been considered to have a possible relationship to Maya Fine Orange and Fine Gray, is included. Also considered are certain pottery samples, from within the Maya area, which provide needed perspective. This is to say that sampling has been extended slightly beyond what many archaeologists would regard as "good". Fine Orange or Fine Gray. Certain Maya fine paste ceramics, which diverge widely from "standard" Fine Orange-Fine Gray, are excluded. In some cases, the divergence was initially observed by the archaeologist on stylistic grounds or because of ware characteristics such as paste color. In other cases, marked divergence within fine paste pottery has been demonstrated by chemical analysis of paste composition, thereby eliminating the pottery from present consideration.

Sampling methods varied in the selection of pottery submitted for neutron activation. In some instances sherds having clearly identified typological affiliations were submitted, although in other cases diagnostics consisted of little more than paste color and texture. Such a frequent lack of clear cultural diagnostics confounds interpretive efforts.

Although Rands (1969) had previously utilized petrography in the investigation of both fine paste and tempered pottery in the Palenque region, the first major attempt to relate petrographic and chemical data for fine paste ceramics was not published until 1975' (Rands et al.). By. 
insufficient analyses prevented firm conclustons from being drawn. Steps were taken to rectify this weakness. Additional thin sections were prepared and analyzed, obtaining comparative information from specimens which had previously undergone neutron activation.

In 1969, sherds from the Peabody Museur excavations at Altar de Sacrificos and Seibal had been submitted to Rands for petrographic analysis, and cerțain of these eventually underwent neurron acclvallun. 'lhus, an expanded, although incomplete, petrogrảphic daca base was estalilslied fü the Altar Ceramic Group. This supplemented extensive petrographic data derived from Rands' survey in northern Chiapas and adjacent Tabasco. All petrographic analyses were carried out by Dr. Pei-yuan Chen, currently with. the Indiana Geological Survey.

The investigative stages sumimarized above encouraged us to seek the finest interpretable partitions provided by the compositional analyses.

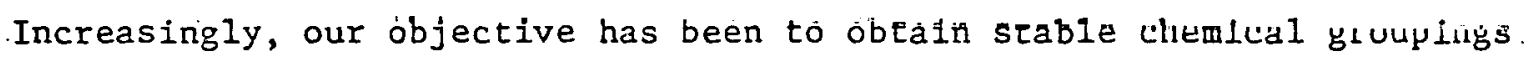
that reflect petrographic patterning and are useful to the archaeologist. The hypothesis of a single locus of Maya Fine Orange manufacture was being tested (Sabloff and Willey 196/; Sabioff 1970, 1973). Prublem areas included the nature of relationships of the Terminal Classic Altar and Balancan Groups of Fine Orange Ware, one to another and with the Tres Naciones and Chablekal Groups of Fine Gray Ware. Compositional relationships with Postclassic Fine Orange ceramics were also being explored as a guide to continuity of the Maya fine paste tradition. Chemical relationships of the Maya materials with fine paste pottery from outside the Maya area could have become an important focus of the investigations, but it was quickly apparent that 
such relationships do not exist in the sampled ceramics on the refined level of analysis which was being followed (cf. Harbottle and Sayre 1975).

Following the preliminary investigations summarized above, a series of steps led to increasing refinement and evaluation of the Fine OrangeFine Gray compositional data. For convenience, these will be numbered sequentially; operationally, statistical analysis proceeded along these general lines.

1. Drawing on Bishop's preliminary report (1976a), Fine Orange and Fine Gray ceramics from the Maya area were viewed relative to fine paste materials of non-Maya provenience. Non-Maya sampling was from Lambityeco,. Oaxaca; El Tajin and San Lorenzo Tenochtitlan, Veracruz; and the Tuxtla area sites of Tres Zapotes, El Picayo, Matacapan and Matalapan. Fine paste oranges and grays were largely represented in this sampling.

Normalizing the chemical variables to the percent of their range, the data were subjected to a Q-Mode factor analysis. Three factors were extracted and rotated to varimax positions. These factors served as apices of a triangular diagram which displays 95 percent of the variation within the data (Fig. 2). The varimax factor matrix is presented in Table 2.

Separation of the Maya and non-Maya pottery is pronounced along the first factor, which primarily reflects chromium and cobalt concentrations. In addition, the non-Maya ceramics tend to separate according to site provenience. The factoral partition of Maya from non-Maya fine pastes appeared sufficiently strong to warrant consideration of pottery from the Maya area as a distinct compositional unit, subject to further subdivision. 
2. A more exhaustive search was made of the extant data base to bring together all examples of Maya-provenience Fine Orange and Fine Gray wares and pottery of apparently close affiliation. Recognizing the problems inherent in a limited sample size, data reduction of this range of fine paste ceramics led to certain heuristic procedures and observations.

2.a. Although the iterative clustering procedure being utilized (CLUS) has performed well in other applications (Bishop 1976b), it has been found to be quite sensitive to highly divergent specimens. Clustering efficiency is lost, groupings tending to isolate individual divergent specimens rather than providing overall patterning within the data set.

To prevent this; removal of the highly divergent specimens appeared useful. This was accomplished by calculating a specimen's Mahalanobis distance $\left(D^{2}\right)$ from the overall group centroid. Those specimens lying outside a 95 percent confidence interval were removed. After five iterations, considerable group stability resulted (Table $\not{\not}$ ). The 76 samples which had not been removed were then ready for "pre-classification" analysis by CLUS (Rubin and Friedman 1967). This total is only slightly less than the 78 sherds which had been removed-pottery that, for one reason or another, had been considered close enough to "standard" Firie Orange-Fine Gray to have been submitted for analysis. Also among the 78 sherds were fine paste materials, from Tortugero and Comalcalco, which had been included for the perspective which they offered to paste compositional or stylistic considerations.

The 76 samples which had been retained by $\mathrm{D}^{2}$ iteration were then input to CLUS. Operating in the space of the first ten principal components; accounting for 99 percent of the variance, CLUS was stepped from two groups 
to seven. At each step group membership was determined in accordance with the maximization of the Wilks-Lambda criterion, i.e. $\log \frac{/ \mathrm{T} /}{\mathrm{W} /}$. of interest is the manner in which the values of the $\log$ maximum $\frac{/ T /}{/ W /}$ reflect the group structure within the Fine Orange-Fine Gray ceramics. Following the initial formation of two groups, a declining gradient is present throughout the graph (Fig. 3 ). The major deflections in the graphed function occur after the formation of five and six groups. The small changes in gradient attest to the overall similarity of the ceramic paste composition. The stronger deflections beyond five groups reflects the formation of splinter groups composed of one or two sherds. Although weakly expressed, five clusters seemed best to represent the number of "natural", empiricallyderived groups inherent in the data. Not fully appreciated at first was the significance of the declining gradient following the initial formation of two groups. A possible explanation for this phenomenon will be given when considering paste compositional units and typological correlations. The now-clustered 76 samples were then subjected to discriminant function analysis using the SPSS package (Nie et al. 1975 ) .2 on the basis of their discriminating power, the chemical variables were selected stepwise by the program. The discriminating criterion was the overall multivariate $F$ ratio used to test the differences between the group centroids. All of the chemical variables were found to contribute significant discrimination. The greatest discrimination was provided by barium and thorium and the lest by titaniurn, sodium and lutecium. The coefficients for the four standardized discriminant functions are listed in Table $\not 1$. Using the classification options of SPSS, 100 percent of the 76 cases were found to be correctly classified; however, four specimens 
had probabilities of group containment outside of the 95 percent confidence interval suggesting that they were not members of any of the groups being considered. These specimens were removed. Three sherds which had been removed during the initial data screening stage and four sherds for which CLUS data were missing were found to have high probabilities of projected group membership according to SPSS and were therefore added to their respective group. A final run through the discriminant analysis revealed 100 percent correct classification with all samples laying within a 95 percent confidence intervai about their respective group centroid.

The five clusters derived by LLUS and evaluated by spss represent our operational Chemical Paste Compositional Reference Units (CPCRUs).3 This set provides the chemical basis for our finest division of standard Fine Orange-Fine Gray--a. "splitter's" rather than "lumper's" view of the archaeological problem: Compression of the five groups is possible;, thereby forming a different set of reference units (see Data Step 2.b).

Correspondence found with the available, independently-derived petrographic data serves as a form of validation of the.CPCRUs. The extent of congruence between chemical and petrographic data provides perspective on the relative utility of a splitting or lumping approach to specific archaeological problems. Although a degree of circularity is involved, an additional form of validation follows from the amenability of the CPCRUs to archaeological interpretation.

The five Maya Fine Orange-Fine Gray CPCRUs will now be considered. as to their substantive content.

The distribution of the five CPCRUs can be seen in two dimensional 4-6

discriminant space. In Figures 3 . The separation of CPCRU 3 from the 
other reference units is apparent along the major axis of-discrimination, the $X$ axis of Figures $\not{\not}$ and $\not{A}$. Also well separated is CPCRU 1 . On the other hand, the combination of the second and third discriminant functions isolates Units 2 and 4 (Figure 6). Throughout, CPCRU 5 maintains a centralized position. For convenience; broken lines have been added to the plot of Discriminant Functions 1 and 2 . These serve to reference the CPCRU positions in subsequent figures, where the sample coordinates are held constint and supplenental information is projected.

Figure, 6 permits correspondences to be seen between the chemicallyderived groups and a single petrographic variable, volcanic dust. The dust, or volcanic glass, is minute in particle size and would occur naturally in the clay matrix rather than being added as a tempering material. Characteristic presence of volcanic dust in all other fine paste. reference units contrasts sharply with its total absence (in petrographically analyzed ceramics) in CPCRU 3. Quantitatively, there is greater abundance of volcanic dust in CPCRUs 2 and 4 than in other units. Thus, from both chemical and petrographic data, CPCRU 3 stands sharply apart. As will be discussed subsequent1y, this unit is mostly represented by decorated types of the Altar Ceramic Group of Fine Orange Ware.

Figures 7 and $\not{q}$ show provenience for the five CPCRUs. Essentially this is done according to site in Figure $\xi$. The regional breakdown in Figure $\$$ corresponds generally to archaeological provenience along the Usumacinta drainage. "Upstream" and "Downstream" positions are indicated. The "Upstream" division comprises the Usumacinta River sites of Piedras Negras and Altar de Sacrificios plus the Pasion River site of Seibal. 
Various sites on the Usumacinta River below Boca del Cerro are included in the "Downstream" category; sherds from Jonuta and Calatrava are best represented.

"Upstream" sites are primarily represented in CPCRUis 3 and 4. Conversely, "Downstream" sites occur largely in Units 2 and 5 . Ly1ng just outside the Usumacinta drainage, the site of Palenque is represented only in the 1 and 5 groupings. Among the comparatively small number of specimens unidentified as to location in Figure $q$, sherds from Yucatan occur mainly in Unit 1 and those frow Peten and Belize mostly in Unie 3. Ir 1s with reference to this distribution within the Usumacinta drainage that the terms "Upstream" and "Downstream" are given an extended connotation, being applied to chemically-defined reference units (CPCRUs 2-5) as well as to their relative geographic position.

2.b. Utilizing the petrographic and distributional patterns, a modification was made, compressing the five CPCRUs into three divisions. Unit 3, striking for its absence of volcanic dust and its strong Upstream locus, was retained. Units 2,4 and 5 were merged. Ceramics of these reference units share appreciable amounts of volcanic dust and a dis-. tribution that is primarily in the Usumacinta drainage. Unit $I$ is characterized by sites lying barely to substantially outside this drainage system. Archaeologically, Silho Group (X) Fine Orange is well represented in this reference unit. With the addition of non-chemical information, a new conceptual category emerged, the Paste Compositional Reference Unit (PCRU). 4 
Chemical variables of this compressed set of three paste corapositional reference units were fed into SPSS, two new discriminant functions being defined (Table $\mathscr{A}^{\prime}$ ). The location of the data points relative to the discriminant axes is shown in Figure $\$$. Again, as evaluated by the classification procedures of SPSS, 100 percent "correct" classification occurred.

2.c. The three PCRUs of step 2.b. were combined with closely. related fine paste materials from the Maya area and finely textured non-Maya pottery of essentially orange and gray paste colors. The petrographically distinct ceramics from Tortugeuro (Rands et al. 1975: 538) were included because of chemical and occasional stylistic similarities to some of the Maya Fine Orange-Fine-Gray pottery, thus providing perspective. Ceramics from the non-Maya sites were included to give Maya Fine Orange a still larger perspective. Subjected to less rigorous clustering procedures, these non-Maya groups have been formed partly on the basis of ceramic provenience, as is suggested by their distribution in Figure 2. Thus, to the three PCRUs were added Tortuguero, which had been removed during initial screening (step 2.a, Table 7.6 ), and the three non-Maya groups. The seven resulting groups were subjected to discriminant analysis. Standardized discriminant function coefficients are given in Table $\not{\phi}$, and the plot of the samples relative to the first two discriminant axes is 11 shown in Figure Sherds from Labityeco, Oaxaca, were projected onto the axes defined for the above groups. The separation observed along the first dimension reinforces the distinction between Maya and non-Maya Fine Orange-Fine Gray as seen in Figure ${ }^{2}$. 
3. A large number of samples, many typologically defined, had been removed as group "outliers" prior to partitioning by CLUS (see step 2.a). Therefore, it was important to consider their possible relationships to reference units that were ultimately obtained. Relationships were viewed relative to the five CPCRUs and the three PCRUs (Steps 2.a, 2.b; Figs. $\frac{4-6,10}{3-5,9)}$ ), each outlying sample being projected onto the discriminant axes. Additionally, each sample's resemblance to the nearest group centroid was calculated. For the five CPCRUs, only eight samples fell within any group's 95 percent confidence interval, whereas 18 samples have this projection for the 7.7 three PCRUS (Table $\underset{i}{-7}$ ).

$A \rightarrow$ $B \rightarrow$

\section{PASTE COMPOSITIONAL UNITS AND TYPOLOGICAL CORRELATIONS}

Non-Maya. Set off chemically from Maya Fine Orange and Fine Gray Wares, three non-Maya fine paste groupings show strong regional patterning (Fig. 10 ). These groups comprise pottery from the major sites of E1 Tajin and San Lorenzo Tenochtitlan and from a site cluster in the Tuxtlas. These clusterings should not be regarded as final; subdivisions are possible, especially in the group defined for the Tuxtlas.. Not included in the above, sherds of Lambityeco provenience pose a special problem. The case by case projection of samples repeatedly indicates strong probabilities of membership in the Tuxtlas group. On the other hand, various dendrogrammatic representations have suggested that some separation between Lambityeco and the Tuxtlas is possible. Although trade in sampled fine paste ceramics can probably be ruled out between the Maya and non-Maya regions, the relationships of Lambityeco and the Tuxtlas remains open to speculation. (Fine paste samples from sites in Oaxaca and Veracruz are considered in detail in Sayre and Harbottle n.d.). 
$B \rightarrow$ Maya: Upstream and Downstream Usumacinta Divisions. Broadly conceived, most of the Maya fine paste pottery sampled in the present investigation has projected affiliations with the Usumacinta. In part, this may be due to the proximity of sites, from which samples were taken, to this river. What is the role of this riverine system? This question has dual aspects. One concerns the Usumacinta as an artery of distribution for fine paste ceramic trade. The second, pertaining more directly to mineralogical and chenical differentiation of naturally occurring materials along the riverine drainage, is crucial to problems relating to resource procurement and manufacture.

Interpretations may now be drawn for the Upstream and Downstream CPCRU distributions of Figure $q$. Recalling the graph of the clustering criterion. function (Fig. ${ }^{3}{ }^{\prime}$ ), the steepest gradient resulted from the formation of two groups. Utilizing the coordinates derived for the five CPCRUs (Step 2.a), a. line has been drawn to enclose one of the two initially formed groups (Fig. In). With few exceptions, the encircled unit dominated by the " $U$ " symbol contains ceramics with an Upstream provenience. Although cutting across petrographic lines for volcanic dust as observed earlier (Fig. (ூ), this suggests that important chemical differentiation is present in the Upstream and Downstream groupings. Apparently the first partition of the data set by CLUS reflects a broad level of riverine chemical differentiation, whereas a number of subsequent partitions form units which are more homogeneous, both chemically and petrographically. 
$B \rightarrow$ Maya: "Usumacinta", "Pasion" and "X" divisions (CPCRUs 2, 4, 5; 3 ; and 1 , respectively). Formation of the three PCRUs (Fig. $\not{\not}$ ) took into consideration chemical, petrographic, geographic and typological information. We now examine the latter aspect.

Fine Orange and Fine Gray wares are shown for the three PCRUs in Figure 13. Fine Gray Ware is relatively abundant in PCRU 2 and virtually absent in PCRU 3. It may be noted, however, that a number of the sherds in the latter group are not fully oxidized.

Ceramic groups are given in Figure $\stackrel{11}{13}$. Partly reflecting differential sampling, the Altar (Y) Group of Fine Orange Ware is well represented in the PCRUs compared to Balacan $(Z)$ and Silho $(X)$, with only a single example of the Matillas (V) Ceramic Group being present. In Fine Gray Ware, the Tres Naclones and Chablekal Groups have modest representation. Miscellaneous fine paste orange and gray pottery, not assigned to ceramic group, are included in the diagram.

The predominance of the Altar Group in PCRU 3 is striking (76. percent). This ceramic group is also represented in PCRU 2 but is absent from Unit 1. The Balancan Ceramic Group (five specimens) can be observed in all units, its greatest frequency being in PCRU 2. Absent from Unit. 3, specimens of the Silho Group are found in PCRUs 2 and 1 . In the latter unit, members of the Silho Group comprise over 50 percent of the total. In the PCRUs, Fine Gray Ware is represented exclusively by the Chablekal Group in Unit 1 and by the Tres Naciones Group in Unit 3, both ceramic groups being present in Unit 2; occurrences are low, however, consisting of only one or two specimens in each unit. 
Ceramic type totals for the three PCRUs are listed in Table 7, which includes categories for Fine Orange and Fine Gray Wares, unspecified as to type. The exclusive occurrence in PCRU 3 of Pabellon Modeled-carved (comprising 32 percent of the unit), Islas Gouged-incised and Cedro Gadrooned suggests a close association with decorated types of the Altar Group.

Maya: "X," "Middle Usumacinta," "Pasion," "Upper Usumacinta" and "Lower Usumacinta" Divisions (CPCRUs 1-5, respectively). Sufficient distributional patterning exists to relate the previously numbered CPCRUs of Data Step 2 (Figs. $\begin{array}{r}4-6 \\ 3-5\end{array}$ ) to geographical loci. Except for " $\mathrm{X}$," these terms have primary reference to subdivisions of the Usumacinta drainage; they are used by extension to designate the CPCRUs which have rntrespnniting gengraphic associations. The units are now viewed from the standpoint of ceramic typology.

Fine Orange and Fine Gray Wares are indicated for the five CPCRUs in Figure 15. Only thinor additional insight is gained over that to be derived from Figure 13 (three PCRUs). Fine Gray Ware constitutes a slim majority of the samples from Unit 4 (Upper Usumacinta); this ware was a minority in each of the three PCRUs.

Ceramic groups for the five CPCRUs are indicated in Figure 15 . Only subdivision of the Usumacinta PCRU 2 gives supplementary information to that shown in Figure 14 . The Balancan and especially Altar Groups reflect the composite nature of the Usumacinta division, being 
broadly represented in the CPCRUs. The Tres Naciones Group, however, has its major occurrence (67 percent) in CPCRU 4.

Ceramic types for the five CPCRUs are given in Table 7 . As before, the Pabellon Modeled-carved association with Pasion (Unit 3) is most pronounced. Both Trapiche Incised and Tumba Black-on-orange -memoer of the Altar Ceramic Group -- have principal compositional association with the Lower Usumacinta (CFCRU, 5).

Maya: Non-reference Unit Fine Paste: Numerous Fine Orange and Fine Gray sherds were removed during the initial stages of Data Sley 7.7

2. Table b.t indicatẹs the stage of removal. Thera specimpns constitute outliers to those ceramics that were subsequently partitioned Into the chemical paste compositional reference units. The outliers are now considered in terms of their resemblance to the centroids of the three PCRUs of Data Step 2.b (Fig. $\not$ ).

$$
17-20
$$

In Figures 16-19, outliers are projected relative to the two discriminant axes defined for the three PCRUs of: Figure $\mathscr{D}$, ines being added to enclose the general regions occupied by each PCRU. Symbols are given to outlier sherds according to ceramic group (Fig$17 \quad 18$ ure 165 and site (Figure $\not 73$. Aithough the majority of the outlying specimens are widely dispersed, recall that some samples projected within a 95 percent confidence interval about a PCRU centroid. A1though general, some inferences can be drawn from the ceramic distributions shown in Figure 17. 
$-51-$

Little patterning exists as to ceramic group in the regions defined for the three PCRUs. In that for Unit 2 (Usuracinta), the Chablekal Group is represented by Palenque and the Dornstream site of Tierra Blanca. Balancan Group cerarics (Provincia Plano-relief Type), sometimes thought to have a Downstream or coastal locus, are represented in the region defined for Unit 3 by the sites of Piedras Negras and Seibal. Two sherds of the Silho Group lie near the region of PCRU I, perhaps further strengthening the association of these ceramic and compositional units.

The most evident patterning observed in Figure 17 is for members of the Matilias (V) Cerainic Group. Widely dispersed, these sherds tend to occupy peripheral positions on the plot and fail to fall within a working confidence interval about any of the PCRUs. Much the same can be said for Fine orange Ware that is unassigned as to ceramic group. Although a few fine Orange specimens project into the regions assigned for the three PCRUs, others are so aberrant chemically as to have coordinates lying outside the limits of the plot. Of interest is the marked heterogeneity of specimens projected into the region of Unit 3. It will be recalled that this unit is based on the chemically, petrographically and typologically stable CPCRU 3. As seen in Figure 20 , the outlier sherds that project into the region of this unit are. generally similar to CPCRU 3 in their absence of volcanic dust. This absence is seen elsewhere in the diagram, however. 
The designation of outliers by site (Fig. 18 . again shows little overall pattern. The small cluster of sherds from Comalcalco is of interest as is an only somewhat less closely spaced grouping of Tortugilero ceramics, although not all specimens from these sites are included in the clusters. Sherds from Becan are widely dispersed yet tend to occupy peripheral positions, low on the $X$ and $Y$ axes. Typological assignment of outliers that did not enter into the formatton of the CPCRUs are given in Table $7 /$. of the total Provincia Plano-relief sherds that are analyzed; only half are readily assignabble to the PCRUs. On this and othcr grounde it appears that the Provincia Type, often considered a Balancan Group diagnostic, is not cohesive compositionally. Four sherds, constituting one-third of the sampling of Pabellon Modeled-carved, are non-assigned outliers, although otherwise the type is markedly homogeneous with its strong - representation in Unit 3. On the other hand, the Altar Orange Type, which is widely distributed among the CPCRUs, has relatively few outliers (20 percent). Insufficient chemical sampling limits discussion of relat1ve compositional uniformity among most of the types.

Table $\mathscr{8}$ Iists, by site, the outlier samples that have had petrographic as well as chemical analysis. In seeking possible explanation of the chemical diversity, it is suggested that chemically aberrant sherds may also be divergent nineralogically. A single 
standard for comparison is necessary; the Usumacinta PCRU 2 of Figure 9 seems best to provide this as it alone merges divisions which are separate in the CPCRUs.

First, it is necessary to characterize petrographically "standard" Maya Fine Orange and Fine Gray as found in the Usumacinta division (Reference Unit 2). Three mineralogical components are pronounced. The clay matrix is consistently micaceous. Volcanic dust, also consistently present, valies in abundance, tonding toward Chen's "Common" through "Rare" range (CPCRUs 2, 4 and 5 in Fig. $\not /$ ). Total feldspar varies considerably but represents about four percent of the grains. The overall characterization can be extended to " $X$ " (PCRU I) in attenuated form and holds generally true, except for the striking absence of volcanic dust, in the Pasion division (PCRU 3).

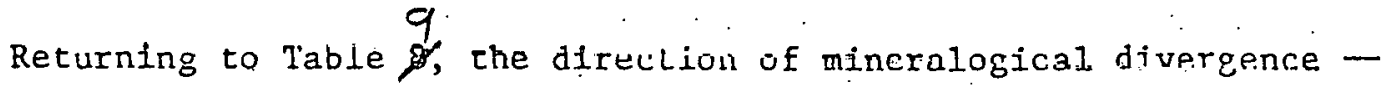
greater or less. than in the Usumacinta -- is indicated. Although sherds occur which do not appear to differ in petrographic diagnostics from those of the Usumacinta division, in approximately 85 percent of the cases deviation on at least one attribute can be observed. The most frequent mineralogical expression of deviance in outlier sherds appears to be the absence of volcanic glass, although the absence of a micaceous matrix may be of at least equal weight in contributing to the degree of chemical variation as a single outlier is considered relative to the Usumacinta. Fine paste ceramics from Comalcalco and Tortuguero require special mention, volcanic dust being consistently 
absent in both cases; additionally, feldspar tends to be unusually abundant at Tortuguero.

The role of the Usumacinta drainage is central to the present structuring of the Maya Fine Orange-Fine Gray problem. It is recognized that "homelands" of this tradicion may lie, in part, outside the drainage. Sherds analyzed chemically at Brookhaven National Laboratory are the basis of the present investigation. With the exception of non-Maya fine paste pottery frum Velacruz and Oaxaca, campling has predominantly been centered on or close to the Usumacinta. It is inevitable, therefore, that conclusions to be drawn from the study have an Usumacinta bias.

Chemical variability has been demonstrated in ceramics having an Usumacinta drainage provenience. Four of the five recognized chenical paste compositional reference units (Figs. $-4-6$ ) apparently relate on distributional grounds to subdivisions of the drainage. Largely, we are discussing Fine Orange of the Altar and Balancan Ceramic Groups, although Fine Gräy Ware, geutedly assignable to tho Tros Nacinnes and Chablekal Groups, is also considered. These ceramic groups fail to provide chemically homogeneous units in paste composition. - Rather, the distribution of chemical clusters is geographically more specific than that of the typological units. A major question confronting us is whether the heterogeneity of typological distribution essentially implies trading activities or is mainly a reflection of variation of raw-material procurement zones within the riverine system. 
Two of the four chemical paste compositional reference units share a geographical locus downstream on the Usumacinta. These units comprise CPCRUs 2 and 5 (Middle and Lower Usumacinta). Within the sampled ceramics, materials from Calatrava and Jonuta predominate in Unit 5. Calatrava is also represented in Unit 2, along with the sites of Trinidad and Arenitas. Upstreaw on the Usumacinta drainage are the chemically and petrographically $4-6,12$

distinct CPCRLis 3 and 4 (Figs. $25,1+$ ); best sampled are Seibal, Altar de Sacrificios and Piedras Negras. Units 2-5 are sparsely represented outside the Usuracinta drainage. Most notable are the Peten site of Uaxactun and the Belize sites of E1 Cayo and Lubaantun, each of these sites being represented in CPCRU 3. Two of the four sampled sherds representing these non-Usumacinta drainage sites are of the Pabelion Modeled-carved Type.

As will be recalled, the non-volcanic CPCRU 3 is exceptionally well represented by decorated types of the Altar Ceramic Group, especially Pabellon. Modeled-carved. Why should this Upstream compositional unit, which has strong chemlcal affiliations with the Usumacinta in general and Unit 4 in particular, be petrographically and typologically distinct? A possible explanation takes into consideration the geological reglons drained by the headwaters of the Usumacinta. The Salinas (Chixoy, Rio Negro) drains the volcanic uplands of Guatemala, thereby contributing a range of volcanic materials such as pumice, ash, and dust. $5 /$ In contrast, the Pasion River arises farther to the north and east in essen= tially non-volcanic terrain. It may be, therefore, that the region of 
resource procurement for CPCRU 3, as well as the archaeological concentration of this unit, lies in the Pasion drainage. The lower Pasion, in particular, is characterized by wide alluvial floodplains. The lagoons, oxbows and probable natural levees (Willey et al. 1975:11) offer an analogous hydrological situation to the lower Usumacinta. Annual flooding in these sertings would have allowed the accumulation of fine sediments, suitable for the production of fine paste pottcry. As shown by analyses at Brookhaven National Laboratory, clay samples from the region of the confluence of the Pasion and Salinas Rivers have strong chemical resemblances to clays obtained downstream on the Usumacinta, from Boca del Cerro to Jonuta. A homogeneous riverine system, with minor chemical differentiation; is indicated. It is under such circumstances that a petrographic variable such as volcanic dust provides means for assessing chemical similarity and differences. Partly as the result of less extensive sampling, we cannot relate specific petrographic and hydrologic information to chemically distinct fine paste pottery, the provenience of which is centered outside the Usumacinta drainage. Nevertheless, more general environmental considerations appear relevant to the problem of sourcing Fine Orange and Fine Gray Wares of non-Usumacinta orientation.

CPCRU 1 may be considered in this connection. Primary cultural affiliations apparently exist to the Silho Group of Fine Orange Ware with secondary associations extending to the Fine Gray Chablekal Group, 
and archaeological proveniences of at least the Silho Group are centered outside the Usumacinta drainage. Nevertheless, it will be recalled that CPCRU 1 was not isolated in the initial formation of two groups by CLUS 12

(Fig. WX), suggesting, as in the case of the other compositional groupings, that Unit 1 has affiliations to sediments from the Usumacinta drainage. Apparently, therefore, the production zone for Unit 1 is not a totally discrete or distant one. Possibly this CPCRU has its source in the deltaic system of the Usumacinta; where mixed sediments account for the observed chemical differences. Such mixture would seem to be most pronounced where distributaries of the Usumacinta and Grijalva merge, but Silho Group pottery is poorly known from this general area. Lying outside the relatively well defined eastern boundary of the Usumacinta delta, sediments to the east and rorth of Laguna de Terminos may be too divergent to have served as raw materials for CPCRU 1; several morphogenic systems provide discontinuities which are probably reflected in the sediment chemistry. Such rivers as the Candelaria empty into the Laguna de Terminos, carrying sediments which may have a different chemical fingerprint than those of the Usumacinta. A hilly karst region extends to the coast between Champoton and Campeche, separating the eastern Tabasco-Campeche alluvial plain from the narrow coastal belt of lagunal swamps and marshes to the north, and in spite of its heavy Silho occupation it appears questionable if the latter zone would provide requisite clays for CPCRU I Fine Orange ware (f́ee West 1964: Figs. 4, 18; West, Psuty and Thom 1969: Figs 16, 17; Eaton 1978: 4, 17-18). The evidence, then, is inconclusive, but these are some of the factors to be reckoned with in attempting to source CPCRU ' 1 or to determine the production zone or zones of the Silho Ceramic Group. 
Compositinnal affiliations with the Usumacinta-oriented CPCRUs seem weaker for the Matillas Group than for Silho ceramics. On the basis of the limited sampling, diverse places of manufacture might be inferred for the chemically heterogeneous Matillas materials. However, a geographically iimited area which includes alluviium from distinct sources could perhaps provide the level of chemical diversity which has bean noted. This requirement might be met if manufacturing comunities were located along active or abanioned channels of the Grijalva and Chilapa before and atter merging wlih weslen distribu taries of the Usumacinta (West, Psuty and Thom 1969; Figs. 8, 15-17). This is, in any case, a zone of abundant Matillas Group ceramics.' How is the trade, as investigated archaeologically, to be assessed? Minor chemical variation, typology, and sherd provenience have shown varying degrees of association. If there is a strongly patterned association, as in the case of Pabellon Modeled-carved, a restricted resource zone with subsequent trade may be lilfeiced. For example, trade from the place of manufacture to such widely separated sites as Piedras Negras and Lubaantun is indicated. If, on the other hand, associations among paste compositfon, typuluyy and provenience are blurred, the resulting lack of pattern gives the archaeologist little basis on which to assess trade. The sometimes arbitrary nature of ceramic typology additionally confounds such assessments. Distinctive clusters of stylistic features or other cultural variables not incorporated in the formal taxonomy provide further evidence on which to evaluate the possibility of trade, yet in the absence of technological information about the ceranic pastes, the diffusion of 
stylistic concepts is normaliy a ready alternative to the exchange of goods.

Obviously, the demonstration of geographically-distinct groups based on differences in ceramic paste does not, in itself, rule out the possioility of trade. Such groups can indeed provide a strong indication of exchange and the directional movement of the traded pottery when several conditions are met. (1) The chemical-compositional units are etrongly clustered in statistical space; differences may be minor but are clearly defined. (2) Members of a single compositional group are found in several areas of differing resource procurement, as determined chemically or mineralogically. (3) These ceramic specimens have compositional configurations that are also diagnostic of one of the resource procurement zones. (The degree of similarity which is requistite between raw clays and finisher ceramic products is a complex matter even in untempered ceramics; chemical and mineralogical changes due to such factors as levigation and firing require further investigation) Unfortunately, geochemical information about resource procurement zones is usually imprecise to lacking; we have been able to refer only in general terms to chemical similarities in clays obtained from the Altar de Sacrificios and Boca del Cerro to Jonuta regions or to the probable absence of volcanic dust in sediments from. the Pasion as compared to those of the Salinas and Usumacinta. On the other hand, the existence of significant environmental differences may be inferred on the basis of strong patterning in the ceramic data as the chemical analytical units and archaeological provenience are juxtaposed. This approach will be developed further in the following chapter; we note here the consistent, nonrandom occurrence of CPCRU 3 
and 4 sherds at Upstream sites on the Pasion and southern. Usumacinta and of CPCRU 2 and 5 sherds to the norih, at Downstream locations. The inference to be drawn from this distribution is that the pottery generally had a localized, rather than extended, spread from its places of manufacture; patterned similarities in composition indicate the use of a limited number of distinguishable clays, each presumably indigenous to a single procurenent-and-production zone. (4) Trade over.a greater distance is to be inferred, however, when exceptions occur to this we.11 established pattern. Examples are ceramics from Jonuta in .CPCRU 3 (Pasion) and Tecolpan in Unit 4 (Upper Üsumacinta) or, in the reverse direction, from Altar de Sacrificios in CPCRU 2 (MIddle Usumacinta) and Seibal in Unit 5 (Lower Usumacinta). When one turns to the more diverse resource procurement zones, the presence of CPCRU 1 pottery at Palenque and Yucatecan sites appears to indicate even more widespread trade but from an as yet unidentified source.

$A \rightarrow$

\section{PETROGRAPHIC OBSERVATIONS}

Although groupings based on chemical variables have been formulated (the CPCRUS) and considered relative to selected petrographic data, supplementary information is useful in characterizing the compositon of "standard" Maya Fine Orange-Fine Gray pottery and its analytical divisions. To this end, frequencies for petrographic variables are given $21-28$

in Figures 20-27. Data are mostly rank-order; class intervals are based ori. Chen's more detailed analyses. 
A partial petrographic profile of Fine Orange-Fine Gray ceramics is based on 46 specimens having membership in the CPCRUs and on variables relating to finely textured particles of mica, volcanic glass, feldspar and opal phytoliths. Four of the CPCRUs are evenly represented ( six to eight sherds each), although a larger number (18) in Unit 5 gives a Downstream bias to the sample. Figures 28 and 21 , which give data for the combined CPCRUs, show coherence in internal $23-28$

etructure ae compared to the individual CPCRUs (Figs. $2 z=27$ ), for which the data do not always show marked patterning. Even so, petrographic diagnostics of the separate units are occasionally suggested, at times forcefully.

A high frequency of "Micaceous" and to lesser degree "Very Micaceous" matrix is observed in Figure. 20 for the CPCRUs as a whole. Frequencies are showi in Figure 21 for other variables relating to mica (muscovite and biotite occurring as grains), and these approximate normal distribution curves centered on the "Rare" interval. As 24 and 25 , seen in Figures 23,24 , the Downstream Units 5 and 2 have slightly higher concentrations of mica grains than the Upstream CPCRUs; the latter, Units 3 and 4 , show almost identical frequency distributions for muscovite. Differences among the CPCRUs are not pronounced in

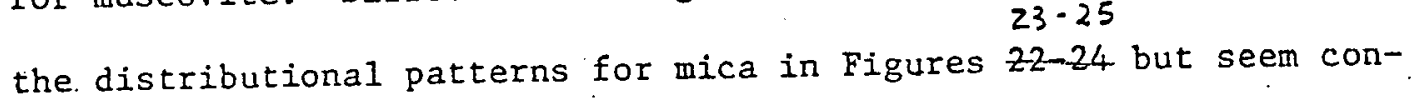
sonant with the Upstream-Downstream partition.

Volcanic dust also peaks on the "Rare" interval for the combined CPCRUs but shows greater variation for individual compositional groups 22,26

(Figs. 2, As discussed earlier, the total absence of volcanic 
dust in CPCRU 3 is striking. Of further interest is the gradual decrease observed sequentially in CPCRUs 4 (Upper Usumacinta), 2 (Middle Usumacinta) and 5 (Lower Usumacinta). Althought sampling is limited, this is congruent with the decreasing concentrations that might be expected as one moves northward frow the volcanic highlands of Guatemala. According to our hypothesis of waterborne transportation of these volcanic particles down the Pasion-Usumacinta and in the absence of overriding factors, the concentration in alluvial deposits would be lessened further from the source area as tributaries, draining non-volcanic terrain, àdded their sedimentary loads to that of the Usumacinta. Clearly, this is a problem requiring expanded technological sampling of the ceramics and problem-oriented field geology.

Feldspar shows generally higher concentrations in the Upstream than Downstream units (Fig. 27 ). Differential abundance is pronounced, however, only in the case of CPCRU 4, and the lowest value is that for Unit 1, geographically peripheral to the Usumacinta drainage. Possibly feldspar has undergone progressively heavier weathering in the Upstream to Downstream sediments. The pattern of decrease along the major artery of the Usumacinta drainage, as expressed in CPCRUs 4, 2 and 5, is that observed for volcanic dust but not for mica grains.

A still different pattern of frequency distributions is found for opal phytoliths, minute opaline particles which are derived from silica-accumulator plants such as grasses (Rovner 1971). Concentrations in the combined CPCRUs are low relative to mica and volcanic dust," phytoliths being undetected (absent or virtually absent) in almost 50 percent of the 22

cases (Fig. 2it). This high 
absence largely reflects frequencies for CPCKUs 3 and 1 (Fig. 28 . For CPCRU 3, the total absence of phytoliths and volcanic dust serves to set off the unit petrographically from the other CPCRUs. In the case of CPCRU l, the general absence of phytoliths combines with random or unstructured frequency distributions in volcanic dust and mica grains to present a distinct configuration within the "standard" Fine OrangeFine Gray materials. Heterogenity of sediments within the CPCRU. 1 procurement region seems to be indicated, and with additional sampling. division of the unit may prove to be necessary. On the basis of the petrographic data considered here, Units 1 and 3 are the most divergent of the CPCRUs; these are the two having loci which are peripheral to the Usumacinta River, forming two of the three PCRUs.

Although patterning exists for petrographic data and the multivariatelyderived chemical groups, it is difficult to discern direct correlation between the discreet mineralogical and chemical variables. Units 2 and 4 separate from the other CPCRUs on the second discriminant axis (Figure $\not 3$ )., which possibly reflects the elemental expression of greater volcanic dust abundance (Figures $\left.\frac{7,26}{n}, 25\right)$. Pravious experimentation by analyzing concentrated volcanic ash fractions of pottery from the Usumacinta sites of Trinidad and Tierra Blanca reveal higher concentrations of barium and rubidium as the ash content increases; this observation appears consonant with the findings of Rice (1978), working with pottery from the Guatemala Highlands. Inspection of the Fine Orange-Fine Gray data, however, fails to strongly support the previous associations (Table 1). see Unlike the pronounced changes in elemental concentrations engendered by the addition of temper (Rice 1978; Bishop 1.979), direct chemical and mineralogical correlations in fine paste pottery must await further experimentation. 
With full recognition of areas of uncertainty due to smallness of sample size and unevenness of geographic coverage, the following conclusions are advanced.

1. Major compositional differences exist between Fine Orange-Fine Gray ceramics from. the Maya died and from the Vcracruz-Oaxaca regions.

2. Within the Maya area, the Usumacinta drainage appears to be a major locus of Fine Orange and Fine Gray production of the rradlifuldily. recognized Altär and Balalllal Cèramic Groupo.

3. Micro-compositional differences are discernible within ceramics from the Usumacinta drainage. This argues against trade from a'single production center. Archaeological proveniences within the reference units suggest Upstream and Downstream divisions. If sampling is repre-sentative, the existence of a number of localized production zones or centers appears highly probable.

4. Pabellon Modeled-carved is the dominant type in a distinct group which may have a manufacturing locus on the Rio Pasion.

5. The S1llu Cexamic Croup forms a snmpwhat. distincl cumpositional unit from those of the Usumacinta drainage. This ceramic group, traditionally associated with Chichen Itza and the Campeche Coast, is best represented in our sample by specimens from Palenque.

The investigation of Fine Orange-Fine Gray ceramics has highlighted certain considerations of methodology. 
1. Problems of lumping or splitting of conceptual constructs have been met by the use of Chemical Paste Compositional Reference Units and Paste Compositional Reference Units. The cherically-based CPCRUs are statistically derived and represent the primary manipulative device. By incorporating petrographic information with the chemical data, the less specific PCRUs enable geographic-environmental correlates to be utilized.

2. Moreover, verffication of chemically-based units by independent data such as that provided by petrology and archaeology is needed. This is especially true when probabilistic statistics are not applicable because of sampling design or insufficient group members.

3. As yet it is not clear if" each of our analytical units, the CPCRUs, relates to various sites within a resource procurement zone or is relatively site. specific as an indicator of manufacturing locale. It will be interesting to see if added sampling results in subdivision of these units.

4. When questions. of trade are probed with highly sensitive analytical techniques, the relationship of ceramic taxonomies and units defined on paste composition must be rethought. What, for example, is the significance of the Altar Orange Type to the exclusion of Balancan Orange in Downstream CPCRUs? Not only must spatial and temporal dimensions be clarified but the adequacy of current taxonomies in dealing with exchange requires re-examination. 
NOTES

1. We wish to acknowledge the importance of the petrographic analyses by Pei-yuan Chen, which early alerted us to compositional heterogeneity in Fine Orange pottery from the western Maya area. This raterial is based on work supported by the National Science Foundation under Grants GS-1455X, BNS76-03397. Regear

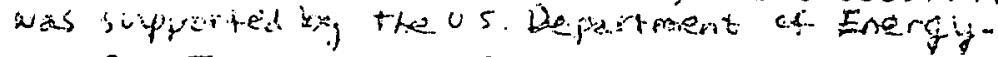

2. The statistical analysis of the. Fine Orange-Fine Gray pottery occurred during 1976-1977. and the original probabilities fo group containment were obtained by, the SPSS, Version 6 discriminant analysis program. Subsequently we have learned that the libM discriminant analysis routine was programmed in a single prectsion, which, at times created exroneous "inflated" probabilities. The probabilities and percentages reported here were recalculated using SPSS, Version 7, implemented on a CDC 7600 corputer.

3. The chemical paste compositional referenre unit (CPCRU) is an operational category derived statistically. from chemical data that relate to ceramic pastes. It offers a means of comparing grouged. chemical data with analogous units. Moreover, it provides a background against which to project non-chemical information. Patterns in the independently projected data serve to validate the CPCRU. A basic problem when using solely chemical information is that of deternining an archaeologically useful level of probability of group membership. An acceptable level of probability, therefore, is relative to a particular research orientation and the amount of patterned similarities between chemical and non-chemical data. 
4. The paste compositional reference unit (PCRU) is a polythetically derived group relating to ceramic pastes against which additional data have been projected. As used in the present paper, it is less. strictly defined than the chemical paste compositional reference unit. We may merge chemical and mineralogical data to from a unit of paste composition that, although less rigorously defined, may be heuristically more userul. Additionally, spatical, temporal or typological information may be input to reformulate a compositional unit that becomes more operational archaeologically. Thus, interfacing of varied data sets characterized the PCRU.

5. The Salinas and its tributaries penetrate the Volcanic Province of Guatemala, as well as draining parts of the Central Guatemalan Cordillera which have thick beds of pumice and dust (Williams 1960; Figs. 1, 2; McBirney 1963: Fig. 1, pp. 206-210; Koch and. Mclean 1975: Figs. 1, 12).

6. Although the Maya Mountains are a source of volcanic ash (Hazelden 1973), their western slope is drained primarily by the northward flowing Chiquibul, rather than by the Pasion (Santa Isabel) and its tributaries such as the Mach ${ }_{n}^{2} q u i l a$ (Wadell 1938: 338-339; Army. Map Service 1964). 
$-68-$

CHAPTER FOUR

Maya Fine Paste Ceramics: An Archaeological Perspective

by

Robert L. Rands, Ronald. L. Bishop, and Jeremy A. Sabloff 
$-69-$

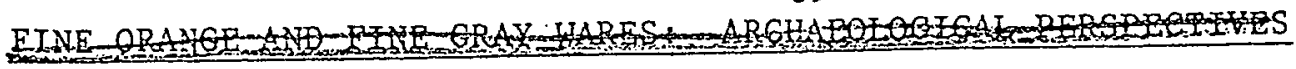

$A^{-} \rightarrow$ OVERVIEW

Most of the patterned chemical differences which have been discussed in the previous chapter are discernible only on a refined level of

analysis. As would have been expected, the widely distributed Altar, Balancan and Silho Ceramic Groups of Fine Orange Ware show close compositional correspondences. But even this body of ceramics is subject to more effective subdivision than would be suspected according to the hypothesis of a common source, Indicating that the shared level of similarity may be on the order of a comon fluvial environment rather than that of a specific locality or tightly nucleated region. Moreover, some Fine Orange pottery from the Maya area, including the poorly sampled Matillas and Cunduacan Groups, lies well outside this compositional range. To go farther afield, based on the present chemical sampling, one can no longer entertain the possibility that fairly intensive, widespread ceramic comerce was responsible for the similarities which exist between Maya and Veracruz-Oaxaca orange or gray fine paste pottery $\left(\in f . \cdots P_{a} d d a c k:\right.$ In the Altar, Balancan and Silho Groups, significant trade continues to be indicated as an exchange that cuts across the formal boundaries of the type-variety system. Certain of the types in the Altar Group such as Pabelion Modeled-carved are fairly stable chemically, appearing to have been widely traded. However, the Alar Orange Type is relatively variable in composition, indicating that a number of manufacturing centers existed, and this is also true of Provincia Plano-relief, traditionally considered a type marker for the Balancan Ceramic Group. The Silho Group, 
which is poorly sampled, may or may not prove to have greater chemical uniformity, but in any case the Silho-oriented compositiunal unit, CPCRU $i$, extends beyond the ceramic group to include non-Silho lypes.

In the ceramic sampling, a bias exists toward the Usumacinta-Pasion drainages and, to lesser degree, the Lower'Grijalva, relative to coastal Campeche, the Yucatan Peninsula, and other portions of the Maya area. In part this reflects problem-orientation (the hypothesis of a single coastal Tabasco homeland and center of production for Fine Orange-Fine Gray ceramics) and in part the fact that the archaeologists who contributed most samples for analysis were connected directly or indirectly with pro-. jects at Seibal and Altar de Sacrificios (Sabloff) and with Fiedras Negras and a regional survey centered on Palenque (Rands). The bias may be implicit in the designation of "Upstream" and "Downstream" chemical groups with reference to the Usumacinta drainage. However, the emphasis is consonant with the probability that clays used in Fine Orange and Fine Gray Ware are naturally transported, apparently exploited from riverine floodplains (Brainerd 1958: 78), and also with the geographic patteming observed in the distribution of the CPCRUs.

An inportant aspect of the parsimonious subdivision of materials largely assignable to the Altar-Balancan Ceramic Groups is provided by petrographic analysis and the demonstration of chemical differences which correlate with the presence or absence of volcanic dust. Perhaps the presence of minute particles of volcanic.glass in some of the fine paste pottery may be ascribed to the weathering of volcanic ash in the Guatemala highlands, 
with subsequent transportation of silt-sized particles down the Salinas.

and thence into the Usumacinta proper. Deposited in lagoons after seasonal flooding, volcanic glass would occur naturally in the clays, serving as an Index to the chemical profiles of ceramics manufactured along the Lower Salinas or Usumacinta; the dust would be absent, however, from. pottery made from alluvial clays on in the drainage system such as the Pasion. According to this interpretation, production centers lying outside the Usumacinta drainage utilized clays which may not only have lacked volcanic dust but were further differentiated by chenical configurations characterizing different river systems. These factors, in conjunction with the complexities of alluvial deposition along the Tabascosouthwestern Campeche coast (West, Psuty and Thom 1969), would appear to account satisfactorily for the compositional variation in those fine paste Maya ceramics reported on in the previous chapter.

It must be understood, however, that the data set is not based on all chemically-analyzed fine paste ceramics from the Maya area, or even on all that would be classed archaeologically as Fine Orange or Fine Gray Ware. Certain sherds which have been analyzed as part of the project have proved to have so little resemblance to the usual chemical profiles for these wares that they have not been considered in Chapter 3. -... To do so would have drastically increased variability within the data set, thereby obscuring variations within the usual Fine Orange--Fine Gray materials. In addition, the present analysis omits specimens which have been reported on in preliminary form from Kixpec and Zacualpa in the Guatemala Highlands

${ }^{1}$ The other great river of the Tabasco lowlands, the Grijalva (Mezcalapa), also deposits volcanic materials derived from the Guatemala highlands (West, Psuty and Thom 1969: 38). 
and the Carlos Greene site in Tabasco (Sayre, Chan and Sabloff 1971; Figs. A.6, A.11; Wauchope 1975: 211, 262, 279). The subject of early investigation, these sherds were not available for reanalysis under current conditions of analytical standardization.

Omitted because of their highly divergent chemical composition are a number of fine paste specimens from the Tamay Complex of Piedras Negras, consisting mostly of oxidized materials which have been designated fine Pale-crange Ware but including reduced examples which would usually be classified as Fine Grayl/ (Rands 1973b: 176-177; Rands et al. 1975). Ceramics having close stylistic and chemical affiliations with the Tamay materials are known from Palenque and Yoxiha, Chiapas, and San Jose del Rio, Tabasco; these specimens, too, are excluded from the present analysis. Nevertheless, correspondences extend to a restricted range of vessel forms and decorative techriques present in the Chablckal Ceramic Group of. Fine Gray Ware. It is evident, therefore, that compositional variation within the Fine Gray materials from the Maya Lowlands is far greater than is indicated in the preceding chapter. W1thin the fine paste tradition, we have been dealing merely with the tip of the iceberg.

Stylistic features wich are sometimes diagnostic in subdividing Fine $0_{2}$ ange Ware extend to chemlcally divesgent ceramics. In the early analysis at the Brookhaven National Laboratory, most of the fine paste pottery from Tortuguero was provisionally excluded from Matching Fine Orange, being designated as a separate group, "Tortuguero high-chromium" (Abascal M.,"Harbottle, Meijers and Sayre 1970). Petrograpinically as well

${ }^{2}$ Although noting close similarities in form and decoration, Brainerd (1958: 78) considers the Piedras Negras materials distinct from bis Fine Grayware of Yucatan. 
as chemically outside the normal range of Fine Orange materials, the orangebrown paste ceramics of Tortuguero have compositional affiliations on the one hand to Fine Orange and on the other to Fine Brown of Palenque (Rands et $\mathrm{a} 1.1975)$. In the present report, the Tortuguero unit is treated heuristically, being included in certain statistical analyses but excluded in others; its outlying position is indicated in Figure 11 of chapter 3. ... It is of no little interest, therefore, that the Balancan Group is. represented in these materials, for Tortuguero lies outside the Usumacinta drainage on the western Maya frontier. Traditionally, the Lower Usumacinta site of Jonuta has been considered a foremost center of $\mathrm{Z}$ Fine Orange (Berlin 1956), and this position is not questioned here. The presence of stylistic features attributable to the Balancan Group in the chemicallyabberant Tortuguero pottery is subject to varied explanations. Because of the general petrographic and chemical stability in the long fine paste tradition at Tortuguero, it is possible that an early stage in the development of the Balancan Ceramic Group is represented (Rands 1973b). On the

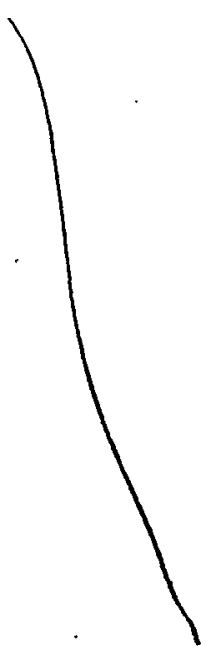


other hand, white-slipped pottery with a fine, creamish-white paste occurs closer to Jonuta, at Trinidad and other Usumacinta sites in the early-facet Naab Complex (Fig. ") and could provide an ancestral form for the white slip characteristic of the Balancan Ceramic Group. Chemically and petrographically, this Fine Cream pottery is far removed from Fine Orange Ware and therefore is not considered in Chapter 3 (Rands 1973b; Rands et al. 1975).

Specimens selected for illustration do not incilude those examples which have already been published in a detailed preliminary report of the Brookhaven Investigations (Sayre, Chan and Sabloff 1971). References to ceramic illustrations are given in Table 7 of Chapter 3 . 
A synthesis is attempted, building on the new compositional perspectives but giving greater weight to major patterns of archaeological distribution, through time and space, than has been accorded the limited number of chemicallyanalyzed sherds. Recognizing problems of sampling, we extrapolate from the juxtoposition of archaeological and chemical data. Discussions are keyed to a series of tables $(10-15)$ and charts (Figs.

10

The Tables. Table $\not$ presents a geographically-ordered alignment of sites frow which project sherds were analyzed and matches this against the CPCRUs, the latter arranged so as to obtain the best patteming. Frequency distributions cluster along a gradient connecting the greater Peten and Upper Usumacinta (upper right) and Middle and Lower Usumacinta, Chiapas-Tabasco Foothills, Lower Grijalva, and northem Yucatan (lower left). This general arrangement of sites and analytical units -- southeast to northwest and north, Upstream to Downstream and miscellaneous -- is maintained for ceramic groups and types in Tables $2-5$.

Although linearly pattemed, it should be noted that this gradient does not conform strictly to a "nearest neighbor" distribution. From the site of Jonuta (Lower Usumacinta), the alignment shifts south and west to sites along the Chiapas-Tabasco Foothills before turning in a northeastem direction to the Yucatan Peninsula. Sites are clustered rather than distributed uniformly along the alignment. Vetermined in part by the arterial system of the Pasion and Usumacinta it is, nevertheless, geographically based rather than random. The sequential correlation of analytical unts (the CPCRUs) with sites and regional divisions along the alignment therefore has significance.

Relationships of the various regional units to archaeological zones of the Maya Lowlands require little comment here (see Culbert 1973). The Upper, Middle and Lower Usumacinta are used as defined in Rands (1973b: $167-69)$; as will be seen, this somewhat unorthodox division conforms well 
to the distribution of the CPCRUs. The Lower Grijalva is defined broadly to include the general area extending east from Comalcalco to the coalesced systems of the Grijalva, Chilapa and Usumacinta Rivers.

Tables $\not 10$ and $\not 1$ differ somewhat, the latter giving CPERU totals as modified by the addition of eight outlier specimens that fall within a group's 95 7. 7

percent confidence interval (Step 3 and Table b.T of Chapter 3.). Totals in the Unplaced column are correspondingly reduced. Using this somewhat less rigorous treatment, patterned alignment of the CPCRUs down the Usumacinta drainage remains virtually unchanged. Five of the added specimens have the expected Upstream or Downstream position and, consistently wi.th Table $\not{A}$, two specimens from the Chiapas foothills are placed in CPCRU 1. The Middle Usumacinta geographical locus of CPCRU 2 is strengthened. Maintenance of pattern on slightly different levels of refinement is indicative of the archaeological utility of the analytical units.

The basis for totals differs from one table to another. Most, although not all, of the analyzed sherds belong to one of the established ceramic groups, and type designations within a group have not always been assigned. Sabloff and Rands examined most of the sherds in May, 1976, and the use of an asterisk indicates a degree of doubt, beyond those general reservations expressed in the text, as to the correct typological identification; in no instance does a total which is so qualified effect more than a single sherd (compare Table 7 in Chapter 3 ). Varieties are not specified.

The Charts. Conforming to the arrangement of the regional units as 10 and 11 given in Tables ceramic complexes are shown in a chronological chart 29

(Fig. $\not{\not}$ ). The chart serves as a base on which to indicate spatial and temporal occurrences of ceramic groups belonging to Fine Gray Ware (Fig. 27 and Fine Orange Ware (Fig. $\not{\beta})$. In some cases, the ceramic group which 
$-77-$

predominates in a given complex cannot be definitely assigned on the basis of published data but educated guesses are attempted; however, the Altar and Balancan Groups are combined, inasmuch as distinguishing criteria often vary in published reports or are incompletely presented. The Early Postclassic Silho Group is accorded special treatment. Its pottery is poorly represented at several of the sites, relationships to Late Classic ceramic complexes being obscure. Rather arbitrarily, therefore, we assign the Silho Group occurrences in the Southern Lowlands to a period between A.D. 900 and 1000, a beginning date somewhat earlier than that generally given but one for which we sense a growing preference among 
workers in the Maya Lowlands (Ball 1978: 102-103). hachured conventions are employed to indicate a relatively abundant representation of closer spacing

a given ceramic group, Arbitrary decisions are unavoidable but it is hoped that the schematic presentation results in minimal distortion of the facts as these are currently understood.

Precision in dating the ceramic complexes from which spectmens have been drawn for chemical analysis varies considerably, as does completeness in ripsribing tho Eine paste assemblages. In general, dating is more finely calibrated for the Southern Lowlands, where indirect ties can be made with Long Count dates, than in those regions for which such information is lacking. This may be a principal reason why perlodizaliun in the Southern Lowlands gives the appearance of more accelerated ceramic change than is observable in Yucatan, although other factors, including relative cultural stability in ceramic production, are perhaps involved. Within . one of the fine paste wares, a single ceramic group is generally shown as predominant throughout a given complex; exceptions are made to this practice when it appears that change in the Fine Orange or Fine Gray pottery. proceded at a faster rate than is discernible for the ceramic complex as a whole. Such instability suggests a specialized, dynamic aspect to fine paste ceramic production and dissenination, and we wonder if this was peculiar to parts of the Southern Lowlands or if chronological refinement would show a comparable rapidity of change in the Yucatan Peninsula.

In looking at the chronological charts, one is impressed by the longevity and intensity of the Fine Orange-Fine Gray tradition on the Campeche Coast compared even to that other region traditionally considered 
a possible homeland for Maya fine paste ceramics, Tabasco. The sustained nature of the tradition is also notable in Yucatan. In part, this may reflect such factors as differences in archaeological sampling and perlodization or differing demographic stability, perhaps related to the Classic collapse and abandonment. Another factor may be the inclusion of Brainerd's (1958) Dzibilchaltun Fine Orange and Ball's possibly related "Isla" Fine Orange-buff (Ball 1978: 95-96) whereas, as previously noted, Rands' Fine Crean of the Middle Usumacinta and Palenque is considered to lie outside the specific Fine Orange-Fine Gray problem and therefore is not included in the charts. Chemically distinctive, untempered orange-paste ceramics are known from still earlier contexts at Palenque 32

(Fig. $f$ ). and on the basis of present evidence we hesitate to ascribe ultimate origins. of the Maya Fine Orange-Fine Gray tradition to the Campeche Coast rather than to Tabasco. This is a reasionable inference, however, if the patteming indicated in Figures 30 and 31 is to be taken at face value. The poor representation of the Campeche Coast in the chemical sampling (one probable specimen) is unfortunate.

With additions and slight modifications, the chronological charts. are based on information summarized by Smith (19.71), Rands (1273a) and Ball (1977, 1978). Distributional summaries, which extend beyond the regions covered in the present project, are given by Smith (1958A 1971: 18-22), Smith and Gifford (1965; Figs, 4, 5) and Ball (1978). A number of reports, some preliminary in nature, relate to Fine orange and Fine Gray Ware in the regions under consideration. Listed under the geographic units employed in Table 10 , with special attention to sites from which sherds have been chemically analyzed, these include: Rio Bec 
(Ball 1977: 45-47, 135); Peten-Belize (Smith 1955: 28-30, 34-35;

Thompson 1939: .150-151, 260; Hammond 1975: 326-328);

Passion-Upper Usumacinta (Sabloff 1970 1973: 119-129A 1975; Adams 1971, 1973a, 1973b; Willey 1972; Butler 1935: 10, 11, 20, 24; Rands 1973b:

176-178) ; Middle Usumacinta (Rands 1969: 10-12, 33-34; 1973b: 178-180);

Lower Usumacinta (Berlin 1956; Shook 19b/; Kands 1973b: 180-183);

Chiapas-Tabasco Foothills (Rands 1967 1969: 56/ 1973b: 190-201今 1974:

73-74; Vaillant 1927: Fig. 385; Dieseldorff 1933; Fi.g. 109; Lchmann 1935; Biom and LaFarge 1926-1927: 226-230);

Figs. 6,8,9 ; Lower Grijalva (Berlin 1956; Peniche Rivero 1973: 38-46, 55-61, 7C-73); Campeche (Smith 195/; Kuz Lhuiller 1969; Halleuy 1970;

Pina Chan 1968; Ball 1978); Yucatan Plains (Brainerd 1941, 1953, 1958;

Smith 1971; Corson 1976; Ball 1978). Especially for Campeche and Yucatan, references include sites or regions additional to those which are represented in the chemical analyses. Thus, Smith's 1971 report on the pottery of Mayapan, which is basic to a comparative study of the Fine Orange ceramic groups, incorporates data from the Puuc. as well as from Chichen Itza.

Beginnings of the Maya Fiue Faste Tradition. The ultimate origin of Maya fine paste pottery may lie in a Gulf coastal tradition extending back to the Preclassic period (Adams 1971: 136). Fine paste pottery of probable Early Classic date, which lies outside the chemical range to be expected for Fine Orange Ware, is known from the Tabasco site of $33 a$

Tortuguero (Fig. . As has been seen, a fine textured, orange-paste figurine from an Early Classic deposit at Palenque diverges even more widely in chemical composition (Fig. 32 ... Early Classic fine paste "Ivory Ware" vessels from Kaminaljuyu and Tikal have 
been considered imports from the Tabasco-Gulf Coast region (Coggins 1975: 152, 276-277); but chemical analysis is not available for this pottery. Little more can be said aside from noting the plausibility of such diversity during the slow adoption of a technological tradition, during which local experimentation in peripheral regions was abetted by sporadic. Ionger distance rrade.

Emergence of Maya Fine Orange and Fine Gray Wares. We are dealing mainly with eerlier segments of the Maya Fine Orange and Fine Gray traditions, a series of distinctive but related developments which took place relatively early in the Late Classic period prior to the rise of the Balancar, Altar and Tres Naciones Ceramic Groups. The earliest of the ceramic groups to emerge may be the Chablekal Group of Fine Gray Ware. Whereas the Altar and Ires Naciones Groups are linked by a number of modes that cut across wares, the Chablekal Group is largely set apart, stylistically and in vessel shape, from possibly contemporaneous Fine Orange.

This conclusion must be qualified. Archaeologists currently working with the concept of a Chablekal Ceramic Group undoubtedly regard it in somewhat different ways. Smith (1971: 18). has identified a number of types for this group but these have not been formally described, and boundaries with the other ceramic group recognized for Fine Gray Ware, Tres Naciones, are inevitably blurred. Chablekal Group ceramics have been characterized as having a matte gray finish which does not differ from the paste (Smith and Gifford 1965: 52) but if other identifying modes indicate group membersinip, pottery with zoned or overall black surface is included with the possibility of separation on a varietal 
level or, as has not been attempted here, by establishing new types. The Chablekal and Tres Naciones Groups have sometimes betn differentiated along temporal lines as belonging to the Late and Terminal Classic periods, respectively (Ball 1978; 82). Thus, on the Campeche Coast, the appearance of the Chablekal Group is placed in the Vacio Ceramic Complex, somewhere in the A.D. 550-700 interval, with Tres Naciones materials characterizing the following Recogida Complex, c. 700-900/1000 A.D. (Fig. $\not 1$ ). However, Smith assigns the Cnablekal Group to the Motul and Cehpech Complexes, roughly spenning both of the Campeche phases; and this dating seems aiso to be indicated in current estimates for Dzibilchaltun (Copo 1 and 2). Farther to the south, in the Chiapas-Tabasco foothills, along the Lower and Middle Usumacinta, and extending upriver as far as Altar de Sacrificios, Rands sees temporal priority of at least some of the Chablekal Group types over those of Tres Naciones. However, the appearance of Chablekal group ceramics on an early Balunte-late Naab-Tamay-early Boca horizon, probably well within the century between A. D. 750-850, is significantly later than dates given for the Yucatan Peninsula. If the various chronological estimates are substantially correct, a northern origin for the Chablekal Group, outside the Tabasco-Usumacinta region, is indicated.

With the exception of the short-lived site-unit intrusion represented by the Tamay Complex at Piedras Negras, the Upper Usumacinta-Pasion region appears to have been little influenced by the Chablekal Group. At Altar de Sacrificios, however, an early-facet Boca cache contained unnamed

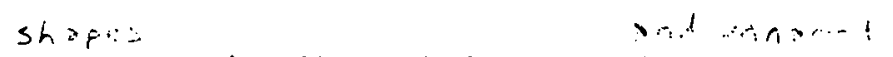
black-slipped vessels which approximate the of the Chablekal Group, 5 hit.l. ......

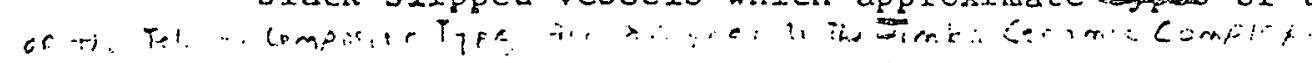

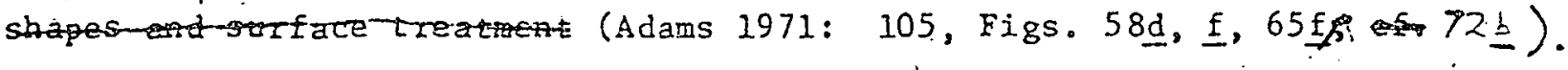

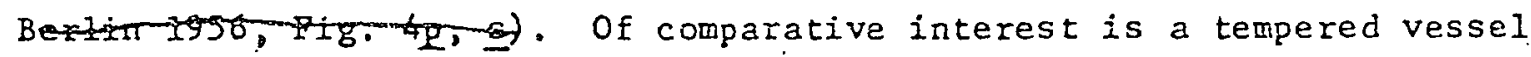
(type undesignated) from a Tepejilote midden at Seibal; in certafn aspects 
THIS PAGE

WAS INTENTIONALLY

LEFT BLANK 
of surface treatment, shape and monkey design, this incised dichrome resembles the Cnicxulub Incised Type of the Chablekal Ceramic Group (Sabloff 1975: 151. Fig. 285). Aberrant at Altar de Sacrificios and Seibal, the for

Cheblekat-affiliated vesse-ts-underscore-the temporal priority of the

Chablekal Group over Tres Naciones within the Fine Gray tradition and indicates affiliations to the north.

Apparentiy untempered orange paste pottery may occur as early as the Chablekal materials but is even less firmiy placed according to ceramic group. The UIum Incised Type, dated at A. D. 670-710 at Tikal, is considered to be a forerunner of $Z$. (Balancan) Fine Orange by Coggins (1975: 276-278, 292), having its source in the Lower Usumacinta-Gulf Coast region. Berlin (1956) and Rands (1973b) note the sporadic occurrence of fine paste orange sherds in relatively early deposits. along the Lower and Middle Usumacinta, as early as the Taxinchan Complex (Tepeu 1 equivalent). As seen above, the Dzibilchaltun Group remains an illusive, vaguely defined construct but again indicates the presence of Fine Orange Ware on a horizon antedating the Altar and Balancan Ceramic Groups.

on the basis of its archaeological distribution and the limited (Figs. $34-36$ ) number of chemical analyses, Chablekal Group pottery $\Lambda$ appears to have been widely traded but from diverse centers. A number of sherds, especially from Tierra Blanca and Palenque, are chemically divergent, failing to find membership in any of the CPCRUs established for Fine Orange-Fine Gray ceramics (Table $\frac{12.1}{\Lambda}$ ). Other sherds in the project sampling attain membership in the Downstream Units 5 and 2 , as well as in the Silhooriented CPCKU 1, but the Upstream Units 3 and 4 are not represented. Little of the early Fine Orange Ware has been analyzed. Failing to achieve CPCRU membership are unnamed sherds from the Taxinchan Complex 
at Trinidad

Palenque (Fig. $33 b, c$ and Murcielagos/early-facet Balunte at

The latter, a unique black and-white painted gouged-incised bowl, bears a glyph band in Classic style. On the other hand, a finely-textured, orange-paste polychrome plate of Late Classic style from Calatrava, dating from late-facet Naab, has membership in the Downstream CPCRU 2 (Fig. 37) There is a vague suggestion that at Calatrava CPCRU 2 may tend to be earlier than the other DownStresu unit, CPCRU 5.

Terminal Late Classic Fine Orange and Fine Gray Wares: the Altar, Balancan and Tres Naciones Ceramic Groups. Developmental stages are complex, apparently being partly rooted in earlier Maya fine paste developments such as those noted above, in part derived from Classic and nonClassic Maya traditions, and also reflecting influences from outside the Maya area. Smith (1971: 237) observes that design characteristics of the Balancan Group conform to those of the Classic Maya ceramlc tradition. The rise of the Altar and Balancan Groups was rapid, a widespread distribution in the Southern Maya Lowlands being probable by A. D. 830 . In particular, firn associations with Long Count dates are present at Seibal in 10.1 .0 .0 .0 (A. D. 849).

The temporal and spatial distribution of the combined Altar and Balancan Groups is indicated in Figure 10 for the regional units included in the present investigation. Were these ceranic groups to be differentiated on the basis of their relative abundance, a traditional separation would Fend to place the ceranic complexcs dominated by the Altar Group on the left hand portion of the chart with those characterized by the Balancan Group occupying the observer's right. Thus, $Z$ (Balancan) Fine Orange has 
been considered to characterize the Campeche Coast (Ruz Lhuil1ier 1969; Matheny 1970) and $\mathrm{Labasco}$ (Berlin 1956; Smith 1958); but as a more tightly defined and restructured typology has emerged under the type-variety system, a strong representation of the Altar Group is Indicated (e.g. Adams $1973 \mathrm{~b}$ for Los Guarixes); much of the pottery which once would have been considered $Z$ Fine Orange is now placed in the Altar Group. It is generally believed that the Altar and Balancan Groups are approximately coeval. Ball (1977: 46) has recently argued that group level separation of types comprising the Balancan and Altar Groups represents an artificial subdivision and should be abandoned.

In estimating relative frequencies of the two ceramic groups in a given complex, we perceive the traditional split to be a valid one in those cases where Altar-Balancan materials are especially abundantly represented. (Fig. 30 Thus, the Altar Group predominates in the Jimba and Bayal Complexes of Altar de Sacrificios and Seibal with the Balancan Group (or at least its decorated types) characterizing the Jonuta Horizon of the Lower Usumacinta.

The Tres Naciones Group of Fine Gray Ware apparently centers at Altar de Sacrificios and Seibal in the Jimba and Bayal Complexes. This picture. may or may not change when the Chablekal Group is adequately described; evaluation of Fine Gray ware as a whole will certainly be in order.

The Altar, Tres Naciones and Balancan Groups comprise the primary membership of CPCKUs $2-5$ and are only occasionally represented in the other chemical reference units. However, of the total of 75 analyzed sherds which belong to the three ceramic groups, 28 percent falls to achleve-inembership in any of the CPCRUs. This is one indication of a substantial degree of compositional heterogeneity within the ceramic groups, as es- 
tablished under the demands of rigorous statistical scrutiny. But what of the patterned variation within the CPCRUs, on the one hand, and in the ceramic groups on the other? Taken in conjunction, the tabies are highly revealing.

A pattern, observable in Table 1 which includes all project sherds from the Maya area, is especially pronounced for the Altar Ceramic Group 12.2

(Table $3+2)$. As one moves northwest from Peten and Belize sites, following Pasion the Siliber and Usumatinta Rivers and the Chiapas-Tabasco Foothills, $n$

archaeological provenience reflects an orderly progression of the chemical compositional units. The Upstream CPCRU 3 dominates the Peten, Belize, Pasion and Upper Usumacinta regions, the other Upstream unit, CYCKU 4, also being represented at Altar de Sacrificios and Piedras Negras. Farther down the Usumacinta, the Upstream units virtually disappear, being replaced by CPCRU 2 along the Middle Usumacinta and Finally by CPCRU 5 on the Lower Usumacinta. This regional configuration of the analytical units is an indication that ceramics of the Altar Group were manufactured at several locations along the Usumacinta drainage with exportation to adjacent regions (the Pasion-oriented CPCRU 3 to the Peten, Belize and Yiedras Negras, the Downstream CPCRU 5 to the Chiapas-Tabasco Foothills).

Attention shifts from ceramic groups to types in Table As to be expected in view of its strong representation, the Altar Orange. Type $38-40$

(Figs. shares the distributional pattern seen for the Altar Ceramic A

Group as a whole. Similar inferences may be drawn, that a number of production centers were coupled with significant although only sporadic widespread trade. However, in the decorated pottery of the Altar Group 41,42

(Figs. $3 \frac{1}{A}$ ), assoclations are tighter between given types and chemical units (Cedro Gadrooned, Islas Gouged-incised and Pabellon Modeled-carved with Upstream CPCRU 3; 
Trapiche Incised and Tumb Black-on-orange with Downstream Unit 5). Additional sampling would be desirable for each of the decorated types, which might be supposed to be more highly prized and therefore to have entered into relatively extensive trade. Membership in only two rather than four of the established CPCRUs may indicate the existence of a smaller number of manufacturing centers for the decorated types, each of which, perhaps, channeled a significant part of its production into a fairly widereaching distributional system. However, in our sampling (26 decorated sherds of the Altar Group and 25 examples of Altar Orange), a greater number of the decorated ceramics are divergent in their failure to achieve CPCRU membership.

The Tres Naciones Group has primary affiliations with Upstream CPCRU 4. In the project sampling as in general archaeological investigations, the Tres Naciones Group is best known from Pasion-Upper Usumacinta sites. At Palenque, CPCRU membership changes to Downstream Unit $(2.4,13.4$, , 13 5 for the single analyzed Tres Naciones sherd (Tables $\lambda$. Fig. A regionalized focus of ceramic trade, rather than widespread commerce, is once again indicated.

The Balancan Ceramic Group reflects greater chemical $12.3,13.3$

variation (Tables $\Lambda$ ). Examples from Pasion-Upper Usumacinta sites are for the most part unplaced in the CPCRUs.. The Provincia Plano-relief Type (Figs. $16-47$ ) is markedly heterogeneous, occurring even in the Silho-oriented CPCRU 1 and the aberrant Tortuguero compositional group. Yet in spite of the compositional diversity, a focus toward the Lower Usumacinta and the west is evidenced in the alignment of site distribution and CPCRU membership. From our sampling we cannot infer the existence 
of significant widespread trade along the Usumacinta in Balancan Group ceramics.

The Altar and Balancan Ceramic Groups are combined in Table $\$$. Major changes from the Altar Group, as shown in Table $\mathscr{H}_{2}$ consist of: (I) increased diversity in the Chiapas-Tabasco Foothilis due to the incluston of two new compositional units, Tortuguero and CPCRU 1 , and (2) a relative-weakening of Yasion-Upper Usumaciula homogeneity, as secn in the increased numbers of sherds which are not.placed in any of the CPCRUs. This is in contrast to the notable tendency of ceramics from sites on the Lower and Middle Usumacinta to be firmly placed in one or another of the currently establjshed compositional units. A possible inference is that during the terminal Late Classic a somewhat smaller number of centers producing Fine Orange $\rightarrow$ Ware were present on the Lower and Middle Usumacinta than in the SeibalAltar de Sacrificios-Piedras Negras area. No unplaced specimens in either the Peten-Belize region or in the Chiapas-l'abasco Foothills result from combining the Altar and Balancan Groups, and the same line of reasoning would suggest that these areas, relatively distant from requisite clays on the floodplains of the Pasion and Usumacinta, were supplied by a limited number of centers which specialized in the standardized production and trade of Fine Orange Ware.

\section{Early Postclassic Fine Orange Ware: the Silho Ceramic Group.}

Traditionally associated with the "Toltec" horizon, this is the most distinctive group of Fine Orange Ware in number of types, elaboration of vessel forms, use of polychrome, and development of abstract symmetry: Stylistic antecedents have been seen to lie in Veracruz, relationships 
to Tohil Plumbate also being noted (Brainerd 1941, 1953). In advocating this position Brainerd adds, however, that "The Mexicans seem...to have arrived as a non-pottery making group and to have superimposed their fashions, but not their techniques, on the local craftsmen," deriving these techniques from the earlier Maya Fine Orange tradition (Brainerd 1958: 276-277). Swith, on the other hand, tends to emphasize stylistic differences between the Silho Ceramic Group and Veracruz Fine Orange Ware and notes stylistic connections of the Silho Group with the Classic Maya ceramic tradition (Smith 1957: 143A 1971: 21, 237). Bal1 (1977: 46) sees significant continuity between Balancan-Altar Group pottery and that of the Silho Group, suggesting that the first appearance of the latter might be at least a century earlier than the traditionally ascribed date of A.D. 1000 (Ball 1978: 102-103).

In the chronological chart (Fig. $\not{Z}$ ), we indicate the beginning of the Silho Group as A.D. 200 in certain easc3 but retain the more conven. tional dating in others. By utilizing the beginning tenth century date at Uaxactun and Palenque, awkward gaps are avoided between the estinated end of Terminal Classic ceramic complexes and the appearance of the rare Silho Group ceramics. Perhaps the horizon marking the appearance of the Silho Group should be lowered for all regions; alternatively, following effective abandonment of sites in the Southern Lowlands, scattered reoccupations by people with Silho Group pottery may have taken place.

The Silho Group is especially, well represented on the Campeche and northwest Yucatan coasts, major inland occurrences being at Chichen Itza, Mayapan and Dzibilchaltun. The approximate southem limit of its continuous distribution on the Campeche Coast is given as Champoton (Ball 1978: 103). Closer to the Usumacinta, in the Magle Complex of Aguacatal, Matheny 
(1970: 89) Identifies the Aguacatal Group as a distinct but coeval ceramic unit, haviny a greater frequency than Silhn. Attention is again directed to the small chemical sampling of Silho Group materials with special reference to Chichen Itza (poorly reprcsented) and the Campeche Coast (completely absent, although the Silho-oriented CPCRU 1 is apparently known from this region, as seen in Table $\underset{A}{\not 10}$ and Figure $\frac{48}{2}$ the other hand, the Chiapas-Tabasco Foothills are disproportionately represented.

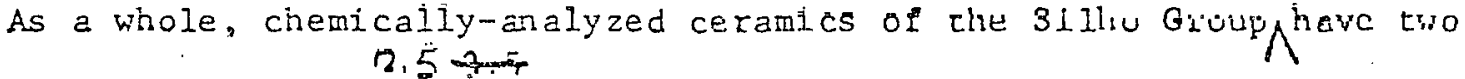
compositional loci (Table $\Lambda$ ). The strongest, CPCRU 1 , is represented at Palenque and nearby Bajio as well as at Chichen ILzd, iulicating videcpread dissemination from an unidentified production center. The Downstream Units 2 and 5 form the second locus, present riot only on the Middle Usumacinta but at Uaxactun. In addition, several sherds, including one from Chichen Itza, are unplaced in the CPCRUs. Of the sampled types, Pocboc Gouged-incised stands out because of its relative compositional variability and lack of membership in CPCRU 1 (Table $A$.

\section{Late Postclassic and Protohistoric Fine Orange Ware: the Matillas} and Cunduacan Ceramic Groups. The better-known Matillas Group of the Late Postclassic is generally believed to have been replaced in the Protohistoric period by the Cunduacan Group. Recognizing the possible primacy of Matillas Group ceramics over those of the Cunduacan Group, Ball (1978: 91-92) believes that Matillas pottery survived into Protohistoric and even Colonial times and that the two ceramic groups are primarily set apart in geographic distribution, Cunduacan in Tabasco and Matillas in Campeche and the Yucatan Peninsula, rather than by temporal factors. 
However, Ball also emphasizes continuities between ceramics of

the Silho and Matillas Groups.

$$
\text { (Figs. } 52,53
$$

Analyzed pottery of the Matillas Group $\eta^{\text {is }}$ from Tabasco and adjacent Chiapas. Chemical heterogeneity is pronounced $12.6,12.713 .6,13.7)$.

(Tables $36,3,3$. Only a single specimen,

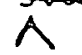

- from Calatrava, has membership in a CPCRU (Unit 5, which is well represented in earliez fine paste ceramics from the site). Lack of standardization in chemical profile suggests that the production of Fine Orange Ware wes less centralized than in the Terminal Classic and Early Postclassic periods. However, definitive conclusions must await wider sampling, especially from sites such as Mayapan to which the pottery was presumably imported. representing the Cunduacan Ceramic Group The single specimen $\Lambda$ is also chemically distinctive.

\section{Fine Orange Ware: Figurines. Moldmade figurines of Fine Orange} paste are best known from Jaina, the adjacent Campeche Coast, Jonuta, and Altar de Sacrificios. Of these, the general Classic Maya figurine. style is present only in examples from Jonuta. In view of stylistic differences both from Jonuta and most Campeche materials, Willey (1972: 62). derives the Jimba figurines of. Altar de Sacrificios from an unknown locality in the Tabasco-Campeche region, and he explains the lack of Fine Orange figurines at Seibal as due to the site's relatively early abandonment or, perhaps, to the closer proximity of Altar de Sacrificios to the source of the figurines (Willey 19.78: 8-9). Corson (1976: 165-166) proposes a localized development of Early Postclassic Fine Orange figurines on the Campeche Coast but sees this as stemming from direct contacts between the Jonuta region and Jaina.

Chemical sampling is limited, consisting of only two figurines. The 
specimen from Calatrava, of generalized Classic Maya style (Fig. 54

luas Mentership in Downstream CPCRU 5. The second, a Eragmentary head from Jonuta in non-Classic style' (Sayre, Chan and Sablofi 1971: Fig. A.10 no. 53), belongs to the upstrean Unit 3. SOURCES OE MAUUACTURE

Places of manufacture which have previously been suggested for the various Fine Orange-Fine Gray cerauic groups are reviewad in the light of new perspectives provided by the Brookhaven analyses. As an initial generalization, it is no longer tenable to look to a limited set of production centers in Tabasco or adiacent Campeche for Fine Orange and Fine Gray Ware, an hypothesis which appeared to be in accordance. with preliminary chemical findings and was developed with special reference to the Altar, Balancain and Tres Naciones Ceramic Groups. To hold this would Ily in the face of the nonrandomly patterned geographic distribution of the analytical. units 3 at sites along the Usumacinta River $\left(x^{2}\right.$ probabilities less than .001 , Table 6). Conclusions about manufacturing centers are much more provisional for the other ceramic groups, which have distributions that do not center on the Usumacinta drainage.

Smith (1958: 153) considers the Altar Group to be centered in the Peten but manufactured elsewhere, as suitable clays would not be available in that limestone region; more specifically southwestem Campeche or eastern Tabasco is designated a likely place of origin (Smith 1971: 162). Seeing compositional identity between the Altar and Balancan Groups, a rumber of recent workers believe Altar Orange and other types in its group to have been manufactured in the general Jonuta area of Tabasco. The chemical analyses and data reduction, in conjunction with sherd provenience and 
mineralogical considerations, indicate the probability of manufacturing Loci un the floodplains of the Pasion and the Upper, Middle and Lower Usumacinta (CPCRUs 3, 4, 2 and 5). Slightly upstream, the alluvial valley of the northern Salinas should perhaps be linked with or substitute for the Upper Usumacinta (CPCRU 4). We cannot be sure whether each of the CPCRUs represents a single manufacturing center or a larger number of pottery-producing communities which cluster statistically on the basis of regional but not site-specific differentiation in the clays. That some specialized production for trade existed may be inferred from the concen tration of decorated types in Units 3 (Pasion) and 5 (Lower Usumacinta) to the exclusion, on the basis of present sampling, of CPCRUs 2 and 4 . The place of origin of the Balancan Group is given as the Campeche Coast by Brainerd (1958: 54). and Ruz Lhuillier (1969: 204) and as southwestern Campeche or eastern Tabasco by Smith (1971: 19, 162). Bal1 (1978: 88) follows Smith in locating the presumed zone of production as somewhere in the eastem. Tabasco-westem Campeche region, including Is la del Carmen. A center of manufacture in the Tabasco-Lower Usumacinta region has often been favored in recent years. Based largely on the Provincia Plano-relief Type, the Brookhaven findings suggest diverse places of production along the Usumacinta drainage (CPCRUs 5, 2 and 3 ) and locations to the west and perhaps north (Tortuguero and CPCRU I).

In comparison to the probably contemporaneous Fine Orange of. the Altar and Balancan Groups, the Tres Naciones Group of Fine Gray Ware appears to have a more sharply defined focus of manufacture (CPCRU 4, with minor representation in Units 3,2 and 5). In view of the distribution and prevalence of volcanic dust in Tres Naciones ceramics, the alluvial valley of the northern Salinas-southern Usumacinta, in the general locality of 
Altar de Sacrificios, is a plausible center of production.

The Stho Group is considered by Brainerd (1958: 57) to have been manufactured in coastal Veracruz or in Tabasco, whereas Sinith believes that it was made somewhere along the Campeche Coast, pointing out that the very rare occurrence of Silho materials tends to eliminate Tabasco as a possible source (Smith 1958: 154/A 1971: 184). Ball (1978: 103) notes an apparent present consensus that the production zone for the Silho Group is located "somewhere along the northwest coast of the Yucatan Peninsula, possibly in the state of Carpeche," a zone that is well separated "geographically from Tabasco. Nevertheless, the Downstrean CPCRUs 5 and 2, which are centered in the Usumacinta floodplain of Tabasco and adjacent. Chiapas, are represented in the Silho Group.

The major focus of Silho, Group production (CPCRU 1) appears peripheral to the Usumacinta drainage but not markedly so. Characterized by the heaviest occurrence of Silho ceramics, the northwest Campeche-.Yucatan coast may be too distant, geographically and in the chemical composition of its clays; to provide the requisite raw materials (Chapter 3 .). This is a problem for future research, and it is possible that silho Group pottery from the region does not relate primarily to CPCRU 1, as we might now infer. Sampling is needed.

The Matillas Group is described as having originated in coastal Tabasco, where it enjoyed its greatest popularity and was manufactured in quantity for exportation to other regions (Smith and Gifford 1965: 531; see Smith 1971: 204). Ball (1978: 92) suggests the possibility of two distinct traditions of Fine Orange production, one of which would link the Silho and Matillas Groups on the Campeche Coast, the second the Altar/ Balancan and Cunduacan Groups farther to the west, Small in number, the 


$$
:-96-\cdot
$$

Matilias and Cunduacan specimens are mostly unplaced in the CPCRUs and with a single exception (CPCRU 5) would appear, therefore, to have been manufactured outside the production areas for both the Usumacinta CPCRUs and Silho-oriented Unit 1 . The analytical data indicate diverse places of production for these chemically-heterogeneous materials. These manufacturing centers may have been widely dispersed or, perhaps, concentrated in a zone of mixed alluvial depostes such as that of the Chilapa, Chilapilla and Grijalva Rivers on the westera edge of the Usumacinta Delta (Chapter

3 .). Potentialiy tinis is an attractive area because of the heavy occurrence of Matillas Group ceramics.

Little published attention has been directed to possible production areas of the Chablekal Ceramic Group of Fine Gray Ware. Compositional similarities exist with the Silho Group, as indicated by membership in the same CPCRUs ( 1,5 and 2 ), but there is a relatively stronger representation of the Downstream Usumacinta units. An unusually large number of the Chablekal Group ceramics are unplaced in the CPCRUs, in. some cases being so chemically divergent as not to have been included in the present statistical analysis. Contrast with the Fine Gray Tres Naciones Group is notable in the degree of compositional heterogeneity as well as in the abserce of Upstream units. A large number of production centers, partly along the Usumacinta but extending well beyond it, is indicated. Once. again, the ambiguous nature of the Chablekal Group as currently understood must be borne in mind, along with recognition of the widespread distribution of at least two of its members, the highly distinctive Telchac Composite and Chicxulub Incised Types. 
CHRONOLOGICAL OBSERVATIONS

The chemlcal paste compositional reference units operate primarily on a spatial rather than temporal dimension; they help the archaeologist to source artifacts rather than to date them. Nevertheless, changes in CPCRU membership can be observed as the Fine Orange and Fine Gray Ceramic Groups are viewed sequentially. A dynamic factor, to be explained in historical and processual terms, is introduced when such changes are pronounced.

CPCRU I is present on both Late Classic and Early Yostclassic levels (the Fine Gray Chablekal and Fine Orange Silho Groups). Its presence on a Terminal .. Classic horizon is less well documented although, as noted, the Silho Ceramic Group may have been present by this time. Much of our. data for this compositional unit comes from Palenque, and in this respect as in others the fine-paste orientation of the site seems different from that of the Southern. Lowlands as a whole. The unusually large number of ceramics which are unplaced in the CPCRUs underscores this difference; compared to the unplaced specimens of Seibal and Altar de Sacrificios, those of Palenque tend to be eliminated on an early $D^{2}$ removal ( $T a b l e \not 10 ;$ lable $\not{7}$ in chapeer 3 ).

Most of the compositional units relate to sources on major rivers in the Usumacinta drainage. Among these, the Downstream CPCRUs 2 and 5 have greater time depth than the Upstream Units 3 and 4. Although best represented in the Terminal Classic Balancan and Altar Groups, CPCRUs 2 and 5 are known in the somewhat earlier and later ceramics of the Chablekal and Silho Groups, respectively: as sampled, Unit 5 continues in Matillas pottery into the Late Postclassic. In contrast, the Upstrean CPCRUs 
3 and 4 are restricted to the Terminal Classic horizon. This differential longevity is consonant with the widely held opinion that the homeland of the Balancan-Altar tradition was downstream, toward the Gulf Coast; a short-lived transplant of this to the alluvial plains of the western. Pasion and Upper Usumacinta-northern Salinas is indicated. It can only be guessed if fine paste pottery utilizing the CPCRU 3 and 4 clays would have continued to be produced in the new location had the Southern Lowlands not suffered drastic depopulation.

Farther downstream, large portions of the Usumacinta also appear to have undergone marked population loss, as may be reflected by a general shift of Fine Orange pottery away from an Usumacinta chemical profile. In composition, the few analyzed examples of Late Postclassic and Protohistoric Fine Orange Ware are so diverse as to argue against pre-1ndustrial mass production at a few major centers; although these techniques of production and distribution might have been so widely shared in Late Postclassic society as to explain the observed chemical diversity (compare Rathje; Gregory and Wiseman. 1978: 168-173).

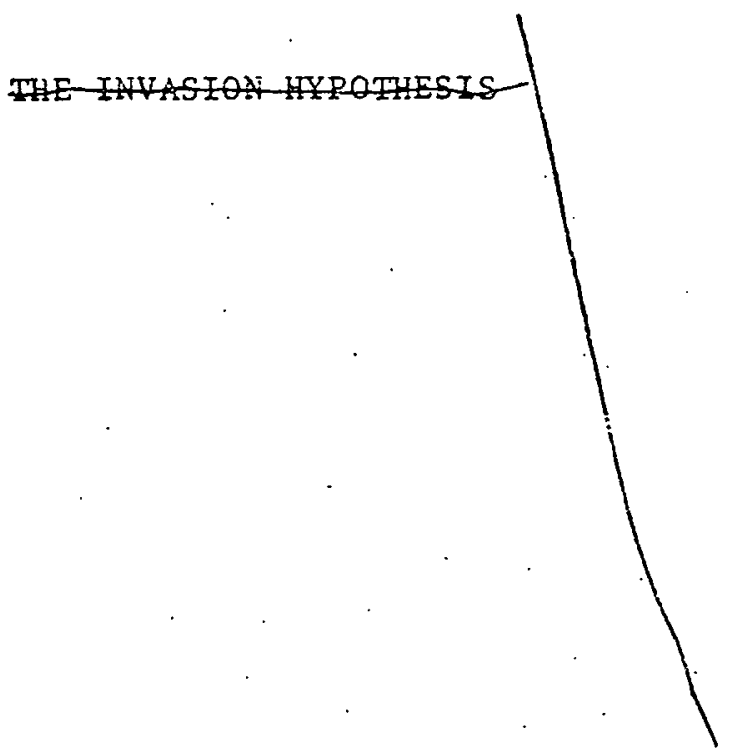


The Invasion Hypothesis

The full scale Fine Paste profect was Infiated in 1967 with the express purpose of testing some simple hypotheses about the probable importation of Fine Paste ceramics into the upper portion of the Pasion-Usumacinta drainage near the close of the Classic Period. Furthermore, these hypotheses were linked with suggestions of possible incursions into the Pasion-Usumacinta drainage by non-Classic Maya peoples and, ultimately, with questions about the relation of postulated incursions with the collapse of classic Maya civilizations.

While there had been a long standing interest in the origins of Fine Paste ceramics (see Smith 1958; Berlin 1956), the excavations at Altar de Secrificios (see Adams 1971, 1973a) and Seibal (see Sabloff 1973, 1975), which found these ceramles in assoctation wth other data which were thought to indicate that the sites had been Invaded, stimulated new Interest in Fine Paste pottery and its orfgins. This interest was further heightened by the discussions at the School of American Research Advanced Seminar on the collapse of Classic Maya clvilization (see Culbert, edftor, 1973) held in Santa Fe in October 1970, In which a more complete picture was revealed of the nature and extent of the spread of Fine Paste ceramics through time and space than hitherto had been avallable. Additionally, the rich Fine Paste tradition in the Palenque region, includIng many non-Flne Orange and Fine Gray types, was discussed In detail 
for the first time by Rands. One result of these discussions was the realization that the development of Fine Paste pottery, or its movement into the Maya lowlands, was much more complex than originally hypothesized at the Beginning of the Brookhaven Project (see Chapter One). Varying hypotheses of at least two major incursions of Fine Paste bearing peoples were brought forward (see Adams 1973a; Sabloff 1973; also see Graham 1973), although the role which such incursions might have played in the collapse, as a cause or as a result, was hotly debated (see Willey and Sabloff 1973 for a summary review). The preliminary results of the Brookhaven Profect appeared to support the early, simpler hypothesis of a single source for much of the Altar Group Fine Orange and Tres Naclones Group Fine Gray and the posstbility of one major incurston into the IIpper IIsumarintaPasion region (Sayre, Chan, and Sabloff 1971). However, significant refinement in measurements, a broadening of the Fine Paste sample, and the additional information provided by the petrographic analyses have shown that these Inftial results offered an oversimplified picture. The results reported in Chapter Three and discussed above in this chapter support a growing feeling among Maya archaeologists that the manufacture and distribution of various Fine. Paste ceramics was quite complex. Moreover, the complicated ceramic situation probably reflects the complex economic changes (see Sabloff and Rathje 1975) and population movements which occurred towards the end of the Classic Period in Southern Mesoamerica. 
The new trends in archaeological thinking about the nature of the Perminal Classic and Early Postclassic Perlods are perhaps best exemplified in the recent writing of Joseph W. Ball (1977, 19.78). On the basis of his ceramic studies in Campeche and Yucatan, Ball (1978-137) polnts out that: "the Middle through Terminal Classic span represents a time of complex and continuousiy changing lines and directions of interaction among the various settlements of the Campeche-Yucatan 11ttoral and those of the peninsular Inland and east coast regions." He argues that the Putun groups of the Tabasco-Campeche reglon, whlch archaeologists, following Thompson (1970), have linked with the manufacture and distribution of Fine Paste ceramics, speculatively may be identified in coastal Campeche as early as the fifth century A. D. and that the Putun were drawn there by the lure of coastal salt resources. The following centuries saw varlous Putun groups and other inland peoples vying for the control of the salt beds, and other resources, and the distribution of the salt (see also Sabloff 1974; Sabloff and Rathje 1975; Eaton 1977; and Andrews 1978, among others). Ball speculates that the complicated patterns of Fine Paste ceramic manufacture and spread reflect the ebb and flow of the fluld economic and political fortunes of differing Putun groups.

The compositional data presented in Chapter Three indicate that the speculative model presented by Ball is worth persuing more rigorously. Unfortunately, the results of the Brookhaven Fine Paste Project cannot be used to test any of Ball's or other scholars' hypotheses 
except in the most general fashion. The results have shown that the Inftial guiding hypotheses of the project were incorrect in their simpleness. Moreover, the avallable data are not complete enough to test more complex phyotheses. However, on the positive side, these data do provide a strong indication of the productive potential of a combined neutron activation-petrographic approach to studying ceramic production and distribution, particularly with the Ideal case of temperless Fine Paste pottery. Furthermore, the CPCRU data provide a framework for future lnvestigations and a clear Indication of the possible production zones which future follow-up studies should sample:

One basic need is an Imaginatively concelved hypothesis which attempts to explain the general economic changes which marked the transitional period from A. D. 800 - 1000 in Southern Mesoamerica. Second, specific predictions about the movement of "Putun".groups and the manufacture and distribution of Fine Paste ceramics could be advanced. Third, the newly developed Bishop-Rands-Sayre-Harbottle analytical procedures comblning neutron activation and petrogrphic studies could be expanded Into a productive methodology which would allow archaeologists to link the predictions of population movements. and ceramic production/distribution with the archaeological record, so as to provide adequate tests of these predictions. Finally, new Fine Paste pottery and clay samples should be collected from appropriate sources, in order to test the predictions.

One of the major contributions of the Brookhaven Fine Paste 
Profect, we belleve, has been the creation of a general foundation for the kind of future study fust outlined. In addition, the project has created the basis for a productive methodology which may allow archaeologists to link ideas of economic development to ceramic production/distribution to population movements or trading activities. What is needed now is ethnographic and/or historic research which will allow archaeologists to first link certain economic behaviors with materlal consequences and, second, to link the material expressions of these behaviors with the nature of the archaeological record. The procedures discussed in this monograph should be indispensible in helping to provide the second 1ink, while research patterned after current successful ethnoarchaeological studies could provide the first.

In sum, both the analytical procedures and substantive results reported here hopefully will stimulate new studies which will build on the start made by the Brookhaven profect. While the profect was infliated in order to test the relationship of Fine Paste ceramics to an hypothesized Invation of the Southern Maya Lowlands by nonClassic Maya peoples during the ninth century A. D. --and ultimately to the collapse of Classic Maya clvilization- archaeologists have come to realize in recent years that the distribution of Fine Paste ceramics is related to broader economic and political changes throughout the Maya lowlands. Moreover, it has become clear that attempts to understand these changes have much more productive potential for explaining the collapse and lack of recovery in the Southern Maya Lowlands 
and the concomitant florescence in the north than those which focus more narrowly on Invasions along the western and southern borders of the Maya Lowlands. Study of the production and distribution of Fine Paste ceramics offers one useful starting point in modeling these changes, and compositional analysis is an important way to begin researching such production/distribution. 
REFERENCES CITED

Abascal M., Rafael, Garman Harbottle, and E. V. Sayre

1974 Correlations Between Terra Cotta Figurines and Pottery From the Valley of Mexico and Source Clays by Neutron Activation Analysis. In Archaeological Chemistry, edited by C. W. Beck, pp, 81-99, American Chemical Soclety, Washington

Abascal M., Rafael, Garman Harbottle, Pleter Meljers and E. V. Sayre 1970 Second Interim Report on the Analysis of Fine Orange (and Other Fine Paste) Ceramics. Brookhaven National Laboratory, Upton, New York.

Adams, R. E. W.

1971 The Ceramics of Altar de Sacrificios; Guatemala. Papers of the Peabody Museum, Vol. 63, No. 1. Harvard Universtty, Cambridge Massachusetts.

1973a Maya Collapse: Transformation and Termination in the Ceramic Sequence at Altar de Sacrificios. In The Classic Maya Collapse, edited by T. P. Culbert, pp. 133-164. . A School of American Research book. University of New Mexdco Press, Albuquerque.

$1973 \mathrm{~b}$ Fine Orange Pottery as a Source of Ethnological Information. 
In Studies in Ancient Mesoamerica, edited by John A. Graham, pp. 1-10. Contributions of the University of California Archaeological Research Facility, No. 18, Berkeley.

Al Kital, R. A., L. Chan and E. Y. Sayre

1969 Neutron Activation Analysis of Pottery fium Hajar Bin Humeid and Related Areas. In Hajar Bin Humeid: Investigarions at a Pre-islamic S1Ee in South Arabla. Appendix II, 387-398. John Hopkins Press, Baltimore.

Army Map Service

1964 British Ilonduras, D.0.S. 649 (Serles E552). Washington, D. C. . Andrews, Anthony $P$.

1978 Puertos Costeros del Postclassico Temprano en el Norte de Yucatan. Estudios de Cultura Maya XI: 75-93.

Arnold, D. E., P. M. RIce, W. A. Jester, W. N. Deutsch, B. K. Lee and R. I. KIrsch

1978 Neutron Activation Analysis of Contemporary Pottery and Pottery Materials from the Valley of Guatemala. In The Ceramics of Raminalfuyu, edited by $R$. $K$. Wetherington, 543-586. 'lhe Pennsiylinaña Stace Unlversilly Pless, 3tate College, Pennsylvania.

Attas, M.; L. Jaffe and J. M. Fossey

1977 Neutron Activation Analysis of Early Bronze Age Pottery from Lake Voullagmen1, Perakhora, Central Greece. Archaeometry $19: 33-43$.

Ball, J. W.

1977 a The Archaeologlcal Ceramics of Becan, Campeche, Guatemaly. 
Middlè American Research Institute, Tulane Unfversity, Publication 43, New Orleans, Loulsiana.

$1977 \mathrm{~b}$ An Hypothetical Outline of Coastal Maya Prehistory: 300 B. C. - A. D. 1200. In Social Process in Maya Prehistory, edited by Norman Hammond, pp. 167-196. Academic Press, London.

1978 Archaeological Pottery of the Yucatan - Campeche Coast. In Studies in the Archaeology of Coastal Yucatan and Campeche, Mexico, pp. 69-146. Middle American Research Institute, Tulane University, Publication 46, New Orleans, Louisiana.

Berlin, Helnrich

1956 Late Pottery Horizons of Tabasco, Mexico. Carnegie Institution of Washington Publication No, 606. Contributions to American Anthropology and History, No. 59, pp. 95-153.

Bieber, Jr., A. M.

1977 Neutron Activatton Analyzing Archaeological Ceramics from Cyprus. Ph.D. Dissertation, University of Connecticut.

Bleber, Jr., A. M., D. W. Brooks, Gorman Harbottle and E. V. Sayre

1976a Application of Miltivariate Techniques to Analytical Data on Aegean Ceramics. Archaeometry 1:59-74.

1976b Compositional Groupings of Some Anclent Aegean and Eastern Mediterranean Pottery. Att1 del Convegni Lincel II. App11cazlone de method nuclearl nel campo della opere d'arte, pp. 111-144. Accademia nazionale die Lincel; Roma. 
Bishop, R. L.

1975 Westem Lowland Maya Ceramic Trade: An Archaeological Application of Nuclear Chemistry and Geological Data Analysis. Ph.D, dissertation, Southern Illinois University, Carbondale, Illinois.

1976a Mayan F1ne Orange Pottery: A Preliminary Report to the Peabody Museum and Brookhaven Nat1onal Laboratory. University Museum, Southern Illinois University, Carbondale, Ill1nols (xeroxed).

1976b Textural and Chemical Variation in a Numerical Study of Western Lowland Maya Ceramlc Trade. In Archaeological Frontler: Papers on New World High Cultures in Honor of J. Charles Kelley. R. B. P1ckering, editor, pp. 1-44: University Wiseum Studies Research Records, No. 4, University Museum, Southern Illino1s Un1versity, Carbondale, Illinois.

1979 Aspects of Ceramic Compositional Modeling. Brookhaven National Laboratory Reports, BNL - 26877, Upton, New York. Blsliup, R. L. and E. Veakis

n.d. Interpreation of Compositional Varlability in Archaeological Objects Using Q-mode Factor Analysis. Unpublished manuscript.

Blom, F. F., and Oliver LaFage

1926-27 Tribes and Temples: A Record of the Expedition to M1ddle America Conducted by the Tulane Untverstiy of Loulstana in 1925. Middle American Research Institute, Publication 1, New Orleans, Louisiana. 
Brainerd, G. W.

1941 Fine Orange Pottery In Yucatan. Revista Mexicana de

Estudios Anthropologicos 5:163-184. Mexico, D. F.

1953 On the Design of the Fine Orange Pottery Found at Chichen

Itza, Yucatan," Revista Mexicana de Estudios Anthropologicos

$13(2$ and 3):463-473, Mexico, D. F.

1958 The Archaeological Ceramics of Yucatan Anthropological

Records, Vol. 19, UnIversity of California, Berkeley and

Los Angeles.

Brill, R. H., (editor)

1971 Sclence and Archaeology, MIT Press, Cambridge, Massachusetts. Brooks, D., A. M. Bieber Jr., Garman Harbottle and E. V. Sayre

1974 Biblical Studies Through Activation Analys1s of Ancient

Pottery. In Archaeological Chemietry, edited by 'C. W. Beck, Pp. 81-99. American Chemical Soclety, New York.

Butler, Mary

1935 Piedras Negras Pottery, Pledras Negras Preliminary Papers, No. 4, Unfversity Museum, Unfversity of Eennsylvanla, Philadelphia.

Caley, E. R.

1962 Analysis of Ancient Glasses 1790-1957. The Corning Museum of Glass, New York.

Coggins, C. C.

1975 Painting and Drawing styles at Tikal; an Historical and Iconographic Reconstruction. Ph.D, dissertation, Harvard University, Cambridge, Massachusetts. 
Cooley, W. W. and P. R. Lohnes

1971 Multivariate Data Anaysis. John Wiley and Sons, New York. Corson, Christopher

1976 Maya Anthropomorphic Flgurines from Jaina Island; Campeche.

Ballena Press Studies in Mesoamerlcan Art, Archaeology and Ethnohistory, No, 1. Ramona, California.

Culbert, T. Patrick

1973 Introduction: A Prologue to Classic Maya Culture and the Problem of its Collapse. In The Classic Maya Collapse, edited by T. P. Culbert, pp. 3-20. A School of American Research book. University of New Mexico Press, Albuquerque.

Culbert, T. Patrick (edftor)

1973 The Classic Maya Collapse. A School of American Research book. Univeristy of New Mexico Press, Albuquerque.

Dieseldorff, E. P.

1933 Kunst und Religion der Mayavolker, Vo1. 3. J. Springer, Berlin.

Eaton, J. D.

1978 Archaeological Survey of the Yucatan-Campeceh Coast. In Studies in the Archaeology of Coastal Yucatan and Campeche, Mexico, pp. 1-67. Middle American Research Institute, Tulane University, Publication 46, New Orleans, Louistana.

Everitt, B.

1977 Cluster Analys1s. Heinemann Educational Books, London. 
Fillieres, D.

19.78 Contribution a L'etude de la production et de l'exportation des amphores dites Marseillaises et des ceramlques Grecques d'occodent de mid1 de la France an Moyen d'analyses par activation neutronique avec traitement taxinomique de resultats. Ph.D. dissertation, University of Paris, Paris.

Fisher; R. A.

1936 The Use of Multiple Measurements In Taxonomic Problems. Ann. Eugen. London 7:179-188.

Flanagan, F. J.

1967 U. S. Geological Survey sllicate rock standards. 'Geochimica et Cosmochimica Acta 31:289-308.

1969 U. S. Geological Survey Standards--II. F1rst compilation of data for the new U.S.G.S. rocks. Geochemica et Cosmochemica Acta $33: 81$.

19731972 Values for International Geochemical Reference Samples. Geochemica et Cosmochemica Acta $37: 1189$

Flanagan, F. J. (editor)

1976 Descriptions and Analyses of Elght New U.S.G.S. Rock Standards. Geological Survey Professlonal Paper 840. United States Government Printing Office, Washington, D. C.

Graham, John A.

1973 Aspects of Non-Classic Presence in the Inscriptions and Sculptural Art of Deibal. In The Classlc Maya Collapse, edited by T. Patrick Culbert, pp. 207-220. A School of American Research book. University of New Mexico Press, Albuquerque. 
Gunnick, R., H. B. Levy and J. B. Niday

1967 Identification and Determination of Gamia and Emitters by Computer Analysis of $E_{g}(\mathrm{LI})$ Spectra. Paper presented at the American Chemical Soclety Symposium on Nuclear Methods of Chemical Analysis, April 10-14.

Hammond, Norman

1975 Lebaantun, A Class1c Maya Realm. Monographs of the Peabody Museum, No. 2, Harvard University, Cambridge, Massachusetts. Hammond, Norman, Garman Harbottle, and T, Gazard

1976 Neutron Activation and Statistical Analysis of Maya Ceramics and Clays from Lubaantun, Belize. Archaeometry:18:147-168. Harbottle, Garman

$1 \quad 1970$ Neutron Activation Analysis of Potsherds from Knossos and Mycenae. Archaeometry:12:23-34.

1976 Activation Analysis in Archaeology. In Radiochemistry; edited by G. W. A. Newton, Chapter 2. The Chemfal Society, London.

1977 Activation Analysis in Archaeology. Radiochemistry, Chemical Soclety Specialist Periodical Report 3:33-72. London. Harbottle, Garman, E. V. Sayre and Rafael Abascal M.

1976 Neutron Actlvation Analysis of Thin Orange Pottery. Brookhaven Laboratory Report, C-1992, Upton, New York.

Harbottle, Garman and Edward V. Sayre

1975 Current Status of Examination of Sherds of Fine Paste Ceramics from Altar de Sacrificios and Seibal and Their Comparison with Other Maya Fine Paste Ceramics. In 
Excavations at Se1bal; Department of Peten; Guatemala,

pp. 241-253. Memoirs of the Peabody Museum, Vo1. 13,

No. 2, Cambridge, Massachusetts.

Hodson, F. R., D. G. Kendall and D. Tautu, (editors)

1971 Mathematics in the Archaeological and Historlcal Sclences,

Aldine, Chlcago.

Hazeldon, John

n.d. The Soils and Geology of the Orange Walk and Corozal

Districts, In British Museum-Cambridge University Corozal

Project, 1973 Interim Report, edited by Norman Hammond,

pp. 74-85, Cambridge, England.

Imbrie, J.

1963 . Factor and Vector Analysis Programs for Analyzing Geologic

Data. Office Naval Research, Geographical Branch, Technical

Report 6.

Imbrie J. and E. Purdy

1962 Classification of Modern Bahamian Carbonate Sediments. In Classiflcation of Carbonate Rocks. American Association of Petroleum Geologists Merolr 7:253-272.

Joreskog, K. G., J. E. Klovan and R. A. Reyment

1976 Geological Factor Analysis. Elsevier Sclentific Publishing Company, New York.

Klovan, J. E. and J, Imbrie

1971 An Algorlthm and FORTRAN-IV Program for Large Scale Q-mode Factor Analyses and Calculation of Factor Scores. Mathematical Geology 3:61-67. 
Koch, A, J, and Hugh McLean

1975 Pleistocene Tephra and Ash-Flow Deposits in the Volcanic

HIghlands of Guatemala.' Geological Society of America

Bulletin 529-541.

Krumbein, W. C. and F. A. Graybili

1965 An Introduction to Statistical Models in Society. McGraw-Hill

Book Co. New York.

Lance, G. N. and W. T. Williams

1967a A General Theory of. Classificatory Sorting Strategles, 1:

Herarchial Systems. Compulei Journal 9:373-2380.

1967b A General Theory of Sorting Strategles, II: Clustering

Systems. Computer Journal 10:271-277.

Lehmann, HeInz

1935 LeFonds du Musee d'Ethnographie du Trocadero de Paris. Maya Research 345-366.

Mason, B.

1966 Principles of Geochemistry. John Wiley and Sons, New York. Mahalanob1s, P. C.

1936 On the Generalized D1stance in Statistics. Proceedings of the National Inst1tute of Science, India 12:49-55.

Matheny, R. T.

1970 The Ceramics of Aguacatal, Campeche, Mexico. Papers of

The New World Archaeological-Foundation, No. 27, Provo, Utah.

McBirney, A, R.

1963 Geology of a Part of the Central Guatemalan Cordillera.

University of California Publication in Geological Sclences

$38(4): 177-231$, Berkeley and Los Angéles. 
Mie, Morma G., C. Hadlla Hull, Jean G. Jenkins, Karin Stelnbrenner and Dale H. Bent.

1975 Statistical Package for the Soclal Sclences. McGraw-H111 New York. Paddock, John

1970 "Oaxaca In Anctent Mesoamerica," In Anclent Oaxaca: Discoveries In Mexico Archaeology and History, John Paddock, editor, pp. 83-242. Stanford University Press, Stanford.

Peniche Pivero, Piedad

1973 Comalcalco, Tabasco: su Ceramica, Artifeactos y Enterramientos. Thesis, Universidad de Yucatan, Merida

Perlman, I. and F. Asaro

1969 Pottery Analysis by Neutron Activation. Archaeometry 11: 21-52. Piña Chan, Roman

1968 Jaina, La Casa en el Agua. Instituto Naclonal de Anthropologia e Historla, Mexico.

Rainey, Froelich and Elizabeth K. Ralph

1966 Archaeology and Its New Technology. Sclence 153:1481-149.1.

Rands Robert L.

1967 Ceramica de la Region de Palenque; Mexico. Estudios de Cultura Maya VI:111-147.

1969 Mayan Ecology and Trade: 1967-1968. Mesoamerican Studies, Untversity Museum, Southern IIlinois University, Carbondale, IIlinols.

1973a The Classic Collapse in the Southern Maya Lowlands: Chronology. In The Classic Maya Collapse, edited by T. P. Culbert, Pp. 43-62. A School of American Research book. University of New Mexico Press, Albuquerque.

1973b The Classic Maya Collapse: Usumacinta Zone and the Northwestern 
Periphery. In The Classic Maya Collapse. edited by T. P. Culbert, pp. 165-206. A School of American Research book. Univers1ty of New Mexico Press, Albuquerque.

1974 The Ceramic Sequence at Palenque, Chiapas. In Mesoamerican Archaeology: 'New Approaches, edited by Norman Hammond, pp. 51-76. University of Texas Press, Austin.

Rands, Robert L., P. H. Benson, R. L. B1shop, P. y. Chen, Garman Harbottle, B. C. Rands and E. V. Sayre

1975 Western Maya Fine Paste Pottery: Chemical and Petrographic Correlations. Actas del XII Congreso Internacional de Americanistas, Vo1. 1, Pp. 534-541, Mexico, D. F.

Rao, C. R.

1948 Tests of Slgnificance in Multivariate Analysis. Biometrika $35: 58-79$.

Rathje, William L., D. A. Gregory and F. M. Wiseman

1978 Trade Modes1 and Archaeological Problems: Classic Maya

Examples. In Mesoamerican Communication Routes and Cultural

Contacts, edited by T. A. Lee and Carlos Navarrete, pp. 147-176.

Papere of the Now Horld Archaeological Foundetion, No. 40, Provo, Utah.

Rice, P. M.

1978 Clear Answers to Vague Questions: Some Assumptions of

Provenience Studies on Pottery. In The Ceramics of

Kaminalfuyu, edited by R. K. Wetherington, pp. 511-542.

The Pennsylvania State University Press, State College,

Pennsylvania. 
Rtchards, T. W.

1895 The Compositfon of Athenian Pottery. Journal of the American Chemical Society 17:152-153.

Rovner, Irwin

1971 Potential of Opal Phytoliths for Use In Paleoecological

Reconstruction, Quaternary Research 1: 343-359.

Rubin, J, and H. P. Friedman

1967 A Cluster Analysis and Taxonomy System for Grouping and

Classifying Data. I.B.M. Corporation, Sclentific Center, New York.

Ruz. Lhuillier, Alberto

1969 La Costa de Campeche en los Tiempos Prehispanicos.

Instituto Nacional de Antropologia e H1storia, Investigaciones, No. 18, Mextco, D. F.

Sabloff, J. A.

1970 Type Descriptions of the Fine Paste Ceramics of the Bayal Boca Complex, Seibal, Peten, Guatemala. In Monographs and Papers in Maya Archaeology, edtted by W. R. Bullard, Pp. 357404. Papers of the Peabody Museum, Vo1. 61, Harvard Un1vers1ty, Cambr1dge, Massachusetts.

1973 Continulty and Disruption During Terminal Late Classic Times at Selbal: Ceramic and Other Evidence. In The Classic Maya Collapse, edited by T. P. Culbert, pp, 107132. A School of American Research book, Univeristy of 2 New Mexico Press, Albuquerque.

1974 Old Myths, New Myths: The Role of Sea Traders in the Development 
of Ancient Maya Civilization. In The Sea In the Pre-

Columbian Wor1d, ed1ted by Elizabeth P. Benson, Pp. 67-96.

Dumbarton Oaks Research Library and Collections, Washington, D. C.

1975 Excavation at Seibal: Ceramics. Mrmolrs of the Peabody Museum, Vol. 13, No. 2, Harvard University, Cambridge, Massachusetts.

Sabloff, Jeremy A, and William L. Rathje

1975 The Rise of a Maya Merchant Class. Scientific American $233(4): 72-82$

Sabloff, J. A. and G. R. W1lley

1967 The Collapse of Maya Civilization In the Southern Lowlands:

A Consideration of History and Process. Southwestern Journal of Anthropology 23:311-336.

Sayre, E. V.

1977 Brookhaven Procedures for Statistical Analysis of Multi-

variate Archaeometric Data. Brookhaven National Laboratory

Report, BNL-21693, Upton, New York.

Sayre, E. V., A. Murrenhoff and C. F, Welck

1958 The Non-destructive Analysis of Ancient Potsherds Through

Neutron Activation. Brookhaven National Laboratory Report, BNL-508 (-122), Upton, New York.

Sayre, E. V., L. H. Chan, and Jeremy A. Sabloff

1971 High-Resolution Gamma Ray Spectoscopic Analyses of Mayan Fine Orange Pottery. In Science and Archaeology, edited by R. H. Bril1, pp. 165-179. The MIT Press, Cambridge Massa. chusets. 
Sayre, Edward V. and Garman Harbottle

n.d. The Analysis by Neutron Activation of Archaeological

Ceramics Related to Teotihuacan: Local Wares and Trade

Sherds. To be published in Urbantzation at Teot thuacan,

Vol. 4, R. Milion, editor. University of Texas Press, Austin.

Scott, A. J. and M. J. Symons

1971 Clustering Methods Based on Likelihood Ratio Criteria. Biometrics $27: 387-398$.

Shook, E. M.

1957 Dentate and Dentate Rocker Stamping from Tabasco. American Ant1quity 22:285-287.

Selge1, S。

1956 Nonparametric Statistics for the Behavioral Sciences. McGraw-Hill, New York.

Smith, Robert E.

1955 Ceramic Sequence at Vaxactum, Guatemala. Middle American

Research Institute, Tulane University, Publication 20, New Orleans, Louisiana

The Marquez Collection of X Fine Orange and Fine Orange

Polychrome Vessels, Carnegle Institution of Washington, Notes on Middle American Archaeology and Ethnology, No. 131, Washington, D, C.

1958 The Place of Fine Orange Pottery in Mesoamerican Archaeology. American Ant1quity 24:151-160. 
1971 The Pottery of Mayapan: Including Studies of Ceramic Material from Uxmal, Kabah and Chichen Itza. Papers of the Peabody Museum, Vol. 66, Harvard Univeristy, Cambridge, Massachusetts,

Smlth, Robert E, and James C. Gifford

1965 Pottery of the Maya Lowlands. In Handbook of Middle

American Indlans, Vol. 2, edtted by Robert Wauchope

(general editor) and G. R. Wllley (vilume editor), PP.

498-534. Universlly uf Térds Tress, Muatin.

Sileath, $P$. and R. R. Sokal

1973 Principles of Numerical Taxonomy. W. H. Freeman and Co.,

San Francisco.

Sokal, R. R, and F. J. Rohlf

1969 Blometry. W. H. Freeman and Company, San Francisco.

Thompson, J. E. S.

1939 Excavations at San Jose, Brit1sh Honduras. Carnēgle

Institution of Washington, Publication 506, Washington, D. C.

1970 Maya History and Religion. University of Oklahoma Press,

Norman .

Valllant, G. C.

1927 The Chronological Significance of Maya Ceramtcs. Ph.D.

Dissertation, Harvard Unfversity, Cambridge, Massachusetts.

Veakis, E.

Archaeometric Study of Native Copper in Prehistoric North America, Ph.D. Dissertation, State Daiyersity _of New York, Stony Brook; New York. 
Wade11, Hakon

1938 Physical-Geological Features of Peten, Guatemala. In The Inscriptions of Peten by $\mathrm{S}, \mathrm{G}$. Morley, Vol. 4, pp. 336-348, Carnegie Institution of Washington, Washington, D. C.

Wauchope, Robert

Zacualpa; El Quiche, Guatemala: An Anclent Provinclal

Center of the Highland Maya. Middle American Research

Institute, Tulane University, Publication 39, New Urleans, Louis Lana.

Welgand, P. C.., Garman Harbottle and E. V. Sayre

1977 Turquoise Sources and Source Areas: Mesoamerica and the Southwestern U. S. A. In Exchange Systems in Prehistory, edited by T. K. Earle and J. E. Erickson, pp. 5-32, Academic Press, New York.

West, R. C. 1964 Surface Configuration and Associated Geology of Middle America. In Handbook of Middle Amertcan Indians, Vol. 1, edited by Robert Wauchope (general editor) and R. C. West (volume editor), pp. 38-83. Univers1ty of Texas Press, Austin.

West, R. C., N. P. Psuty and B. G. Thom 1969 The Tabasco Lowlands of Southeastern Mexico. Louisiana State University Press, Coastal Studies Serles No, 27 , Baton Rouge, Loulsiana.

Wilks, S. S. Mathematical Statistics, John Wiley and Sons, New York. 
Willey, Gordon R.

1972 The Artifacts of Altar de Scarificios. Papers of the Peadoby Museum, Vo1. 64, No. 1, Harvard University, Cambridge, Massachusetts.

1978 Excavation at Setbal: Artifacts. Memoirs of the Peabody Museum, Vo1. 14, No. 1, Harvard Untversity, Cambridge, Massachusetts.

Willey, Gordon R, and Demitri B. Shimkin

1973

Tho Maya Sollapse: A Summary Vlew. In The Classic Maya Collapse, edited by T. P. Culbert, pp. 457-502. A Schoo1 of American Research book. University of New Mexico Press, Albuquerque.

Willey, Gordon R., A. L. Smith, Galr Tourtellot III, and Ian Graham

1975 Excavations at Seibal: Introduction: The Site and Its Setting. Memolrs of the Peabody Museum, Vol, 13, No. 1. Camb ridge, Massachussets.

Willlams, Howel

1960 Volcanic History of the Guatemalan Highlands. University of Califomia Huhltrafions in Geological sclentes, Vol. 38, No. 1, pp. 1-86, Berkeley and Los Angeles. 


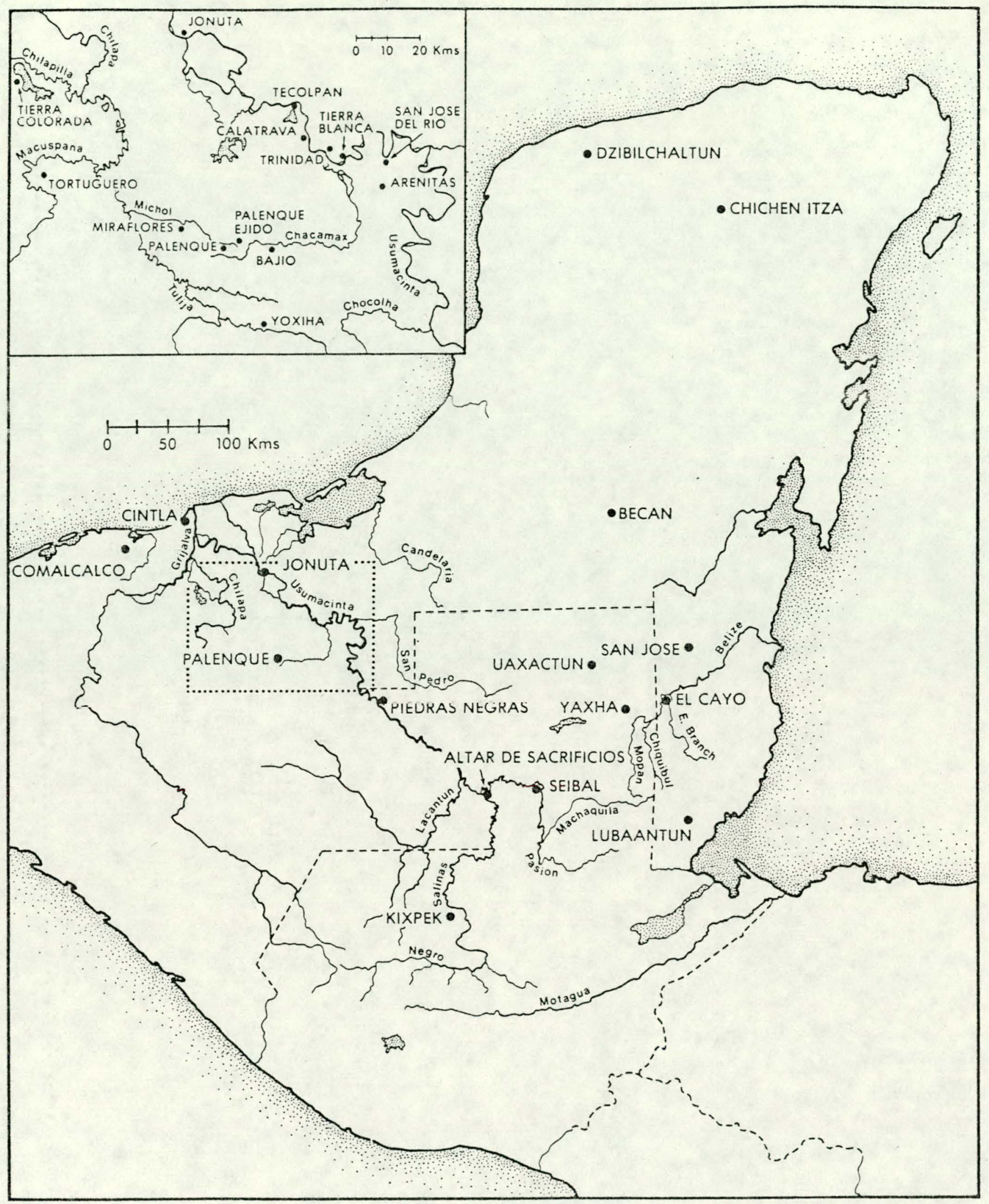

Figate I 


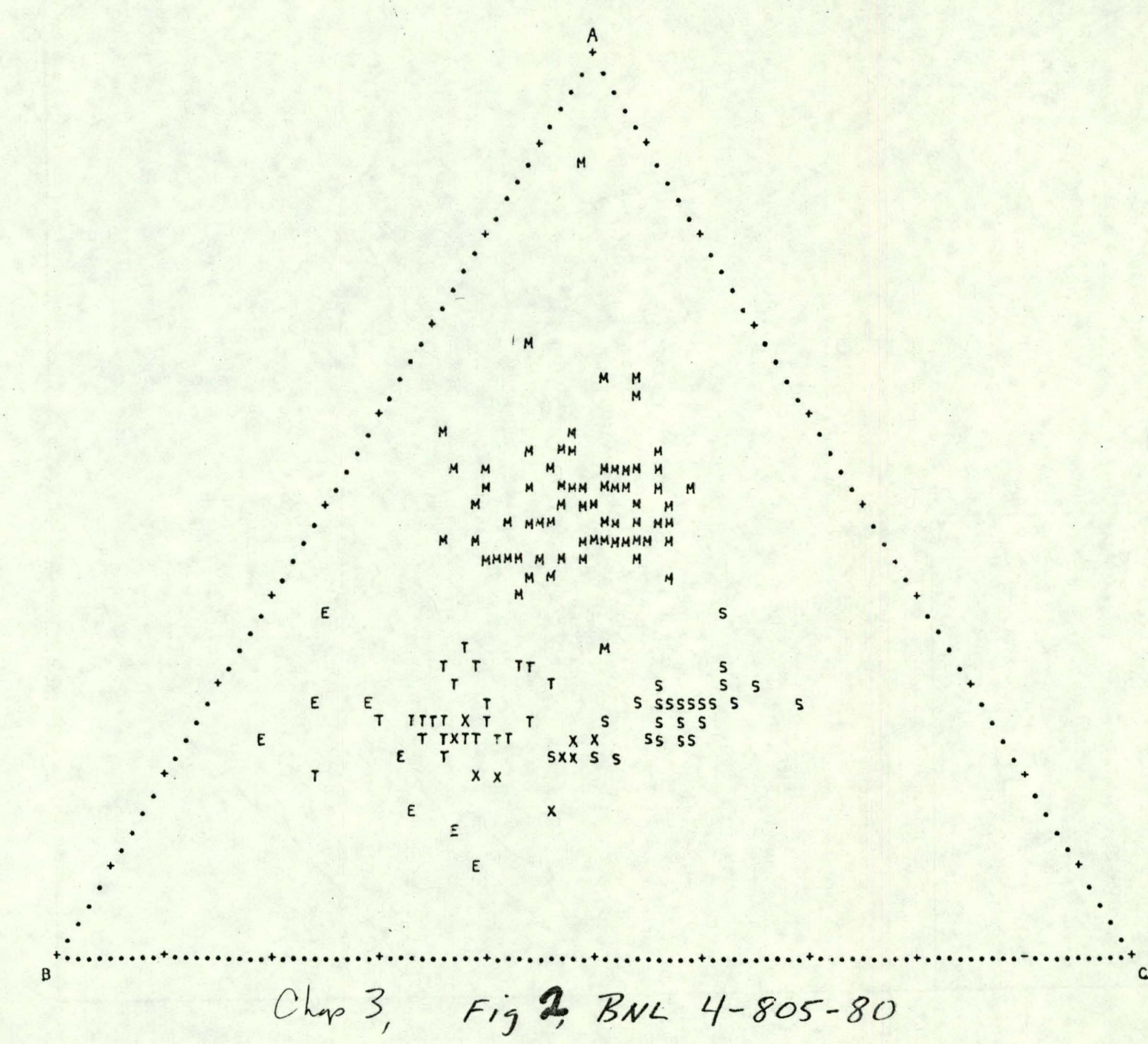




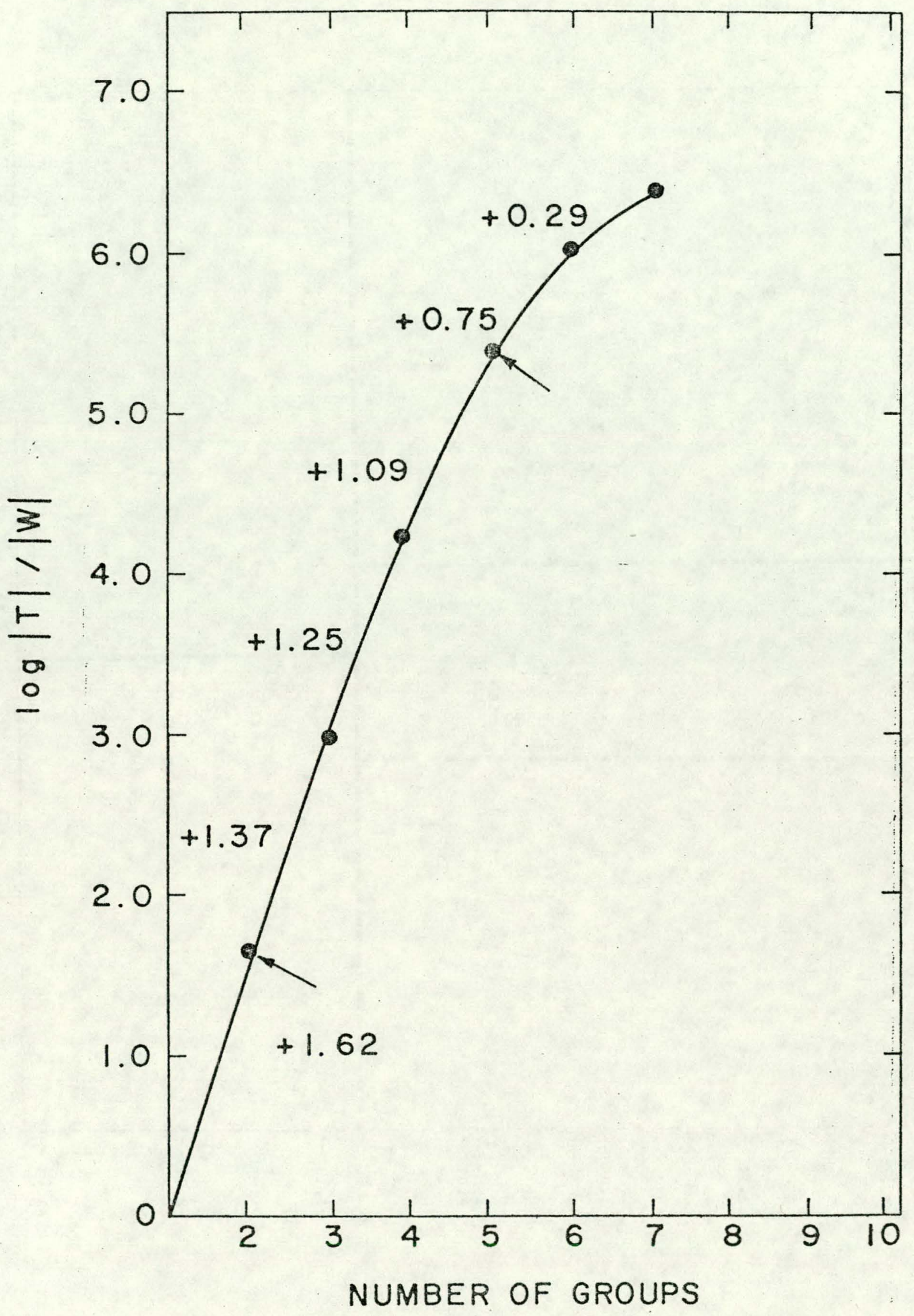

Chap 3, Fig 3, BNL 4-888-80 
DF 2

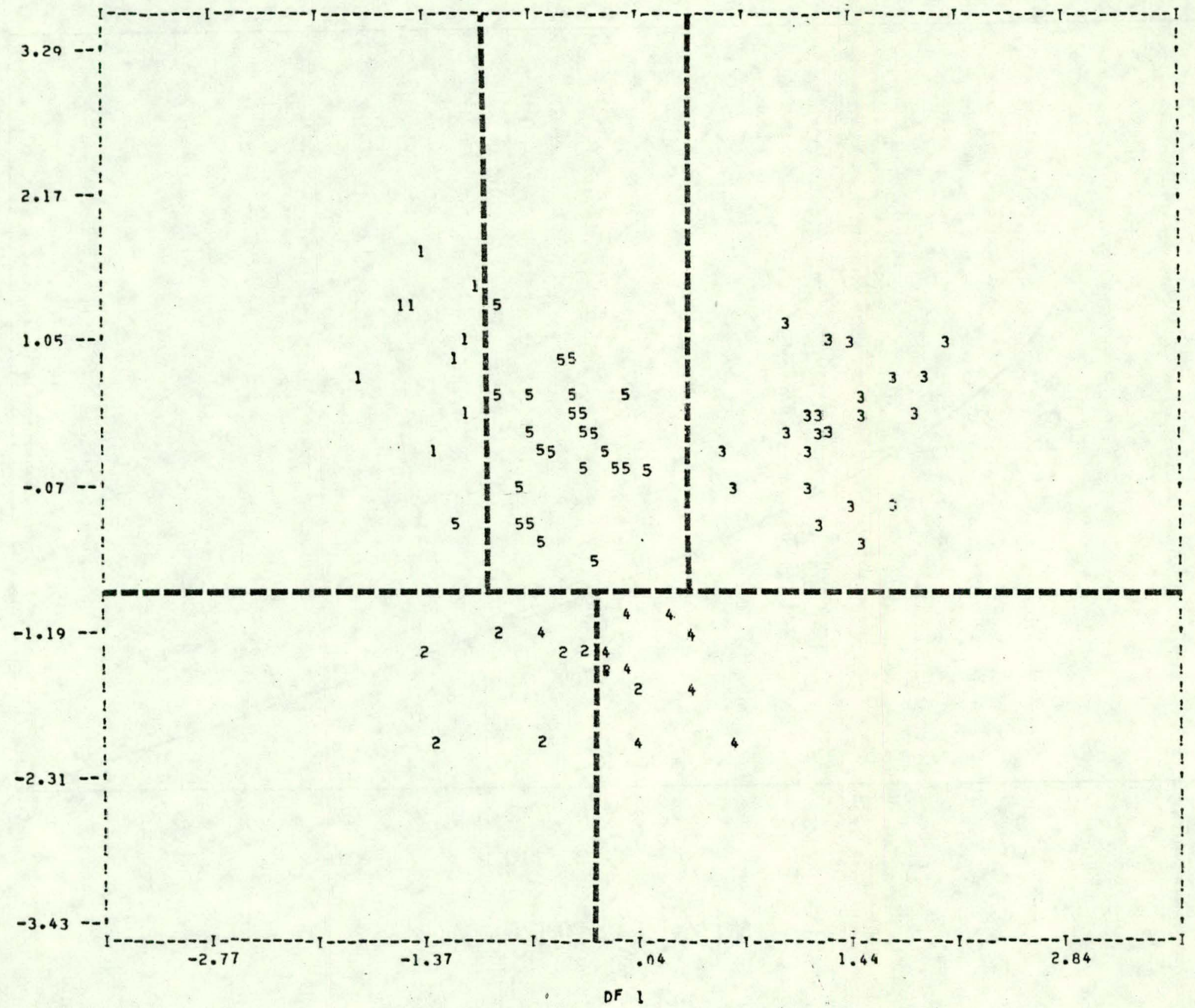

Figy $B N L-4-225-30$ 
DF 3

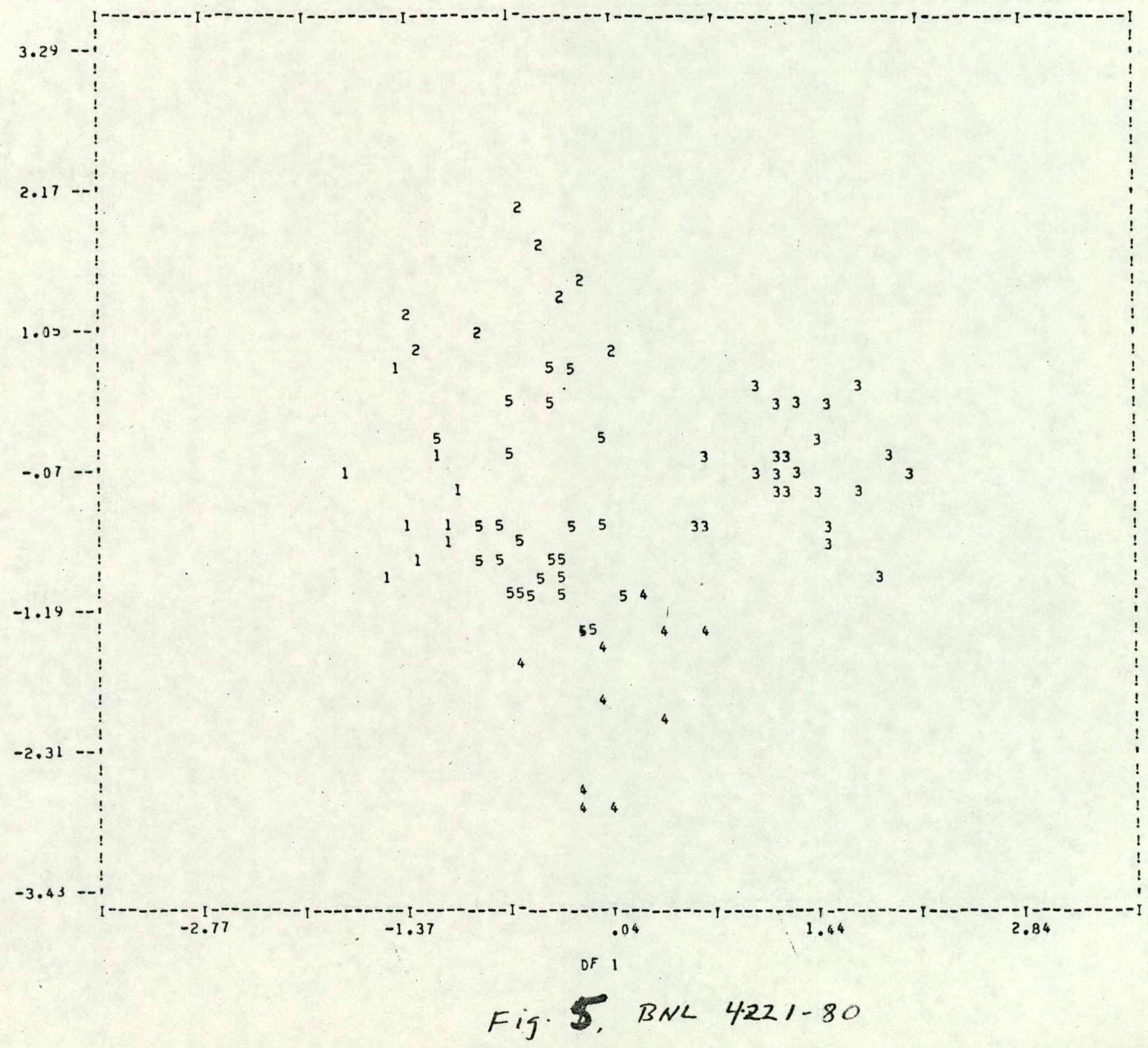




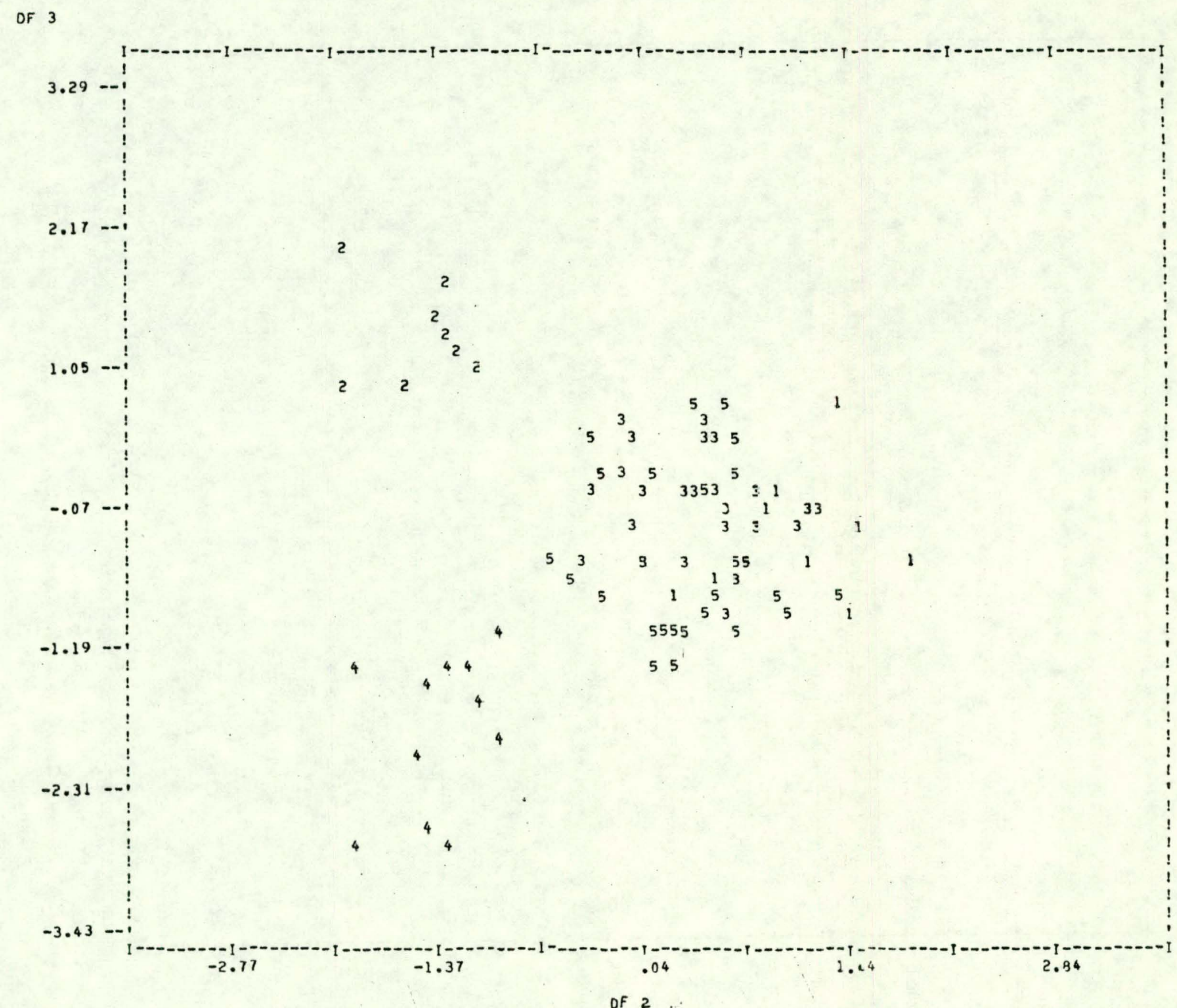

Fig 6. BNL 4-219-80 
DF 2

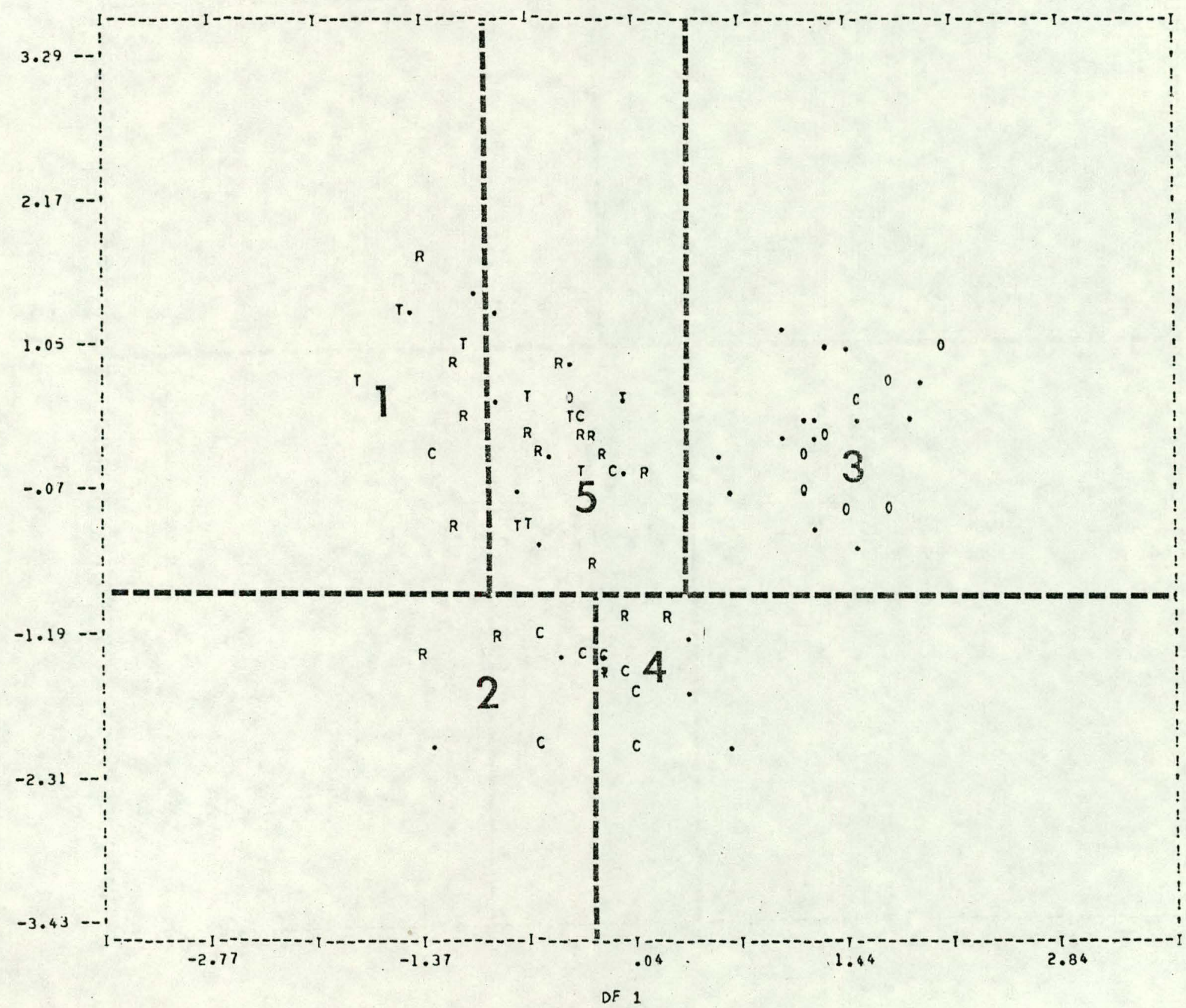

Fig $\%, B N<4-226-80$ 
DF 2

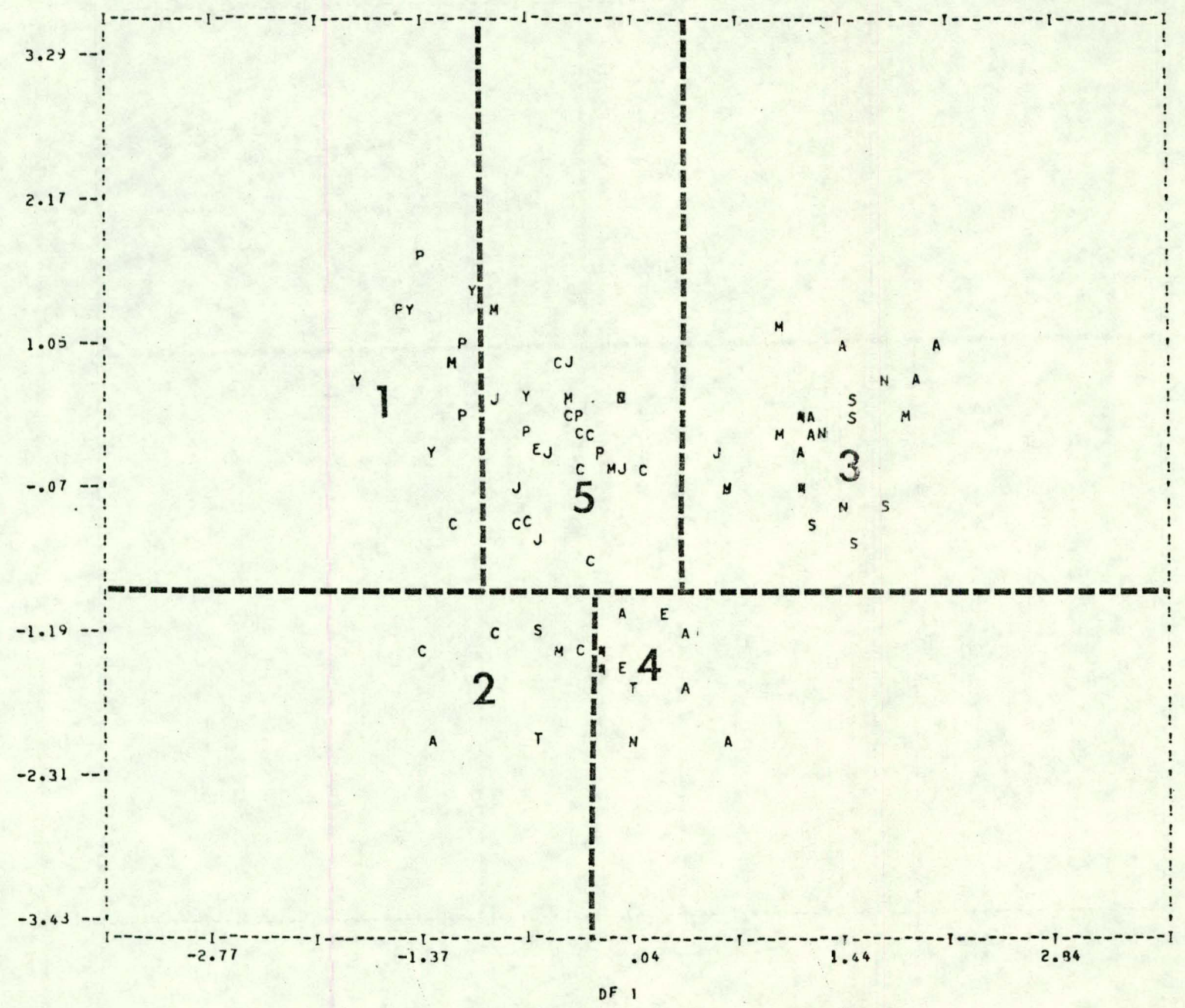

Fig B BNL 4-220-80 
DF 2

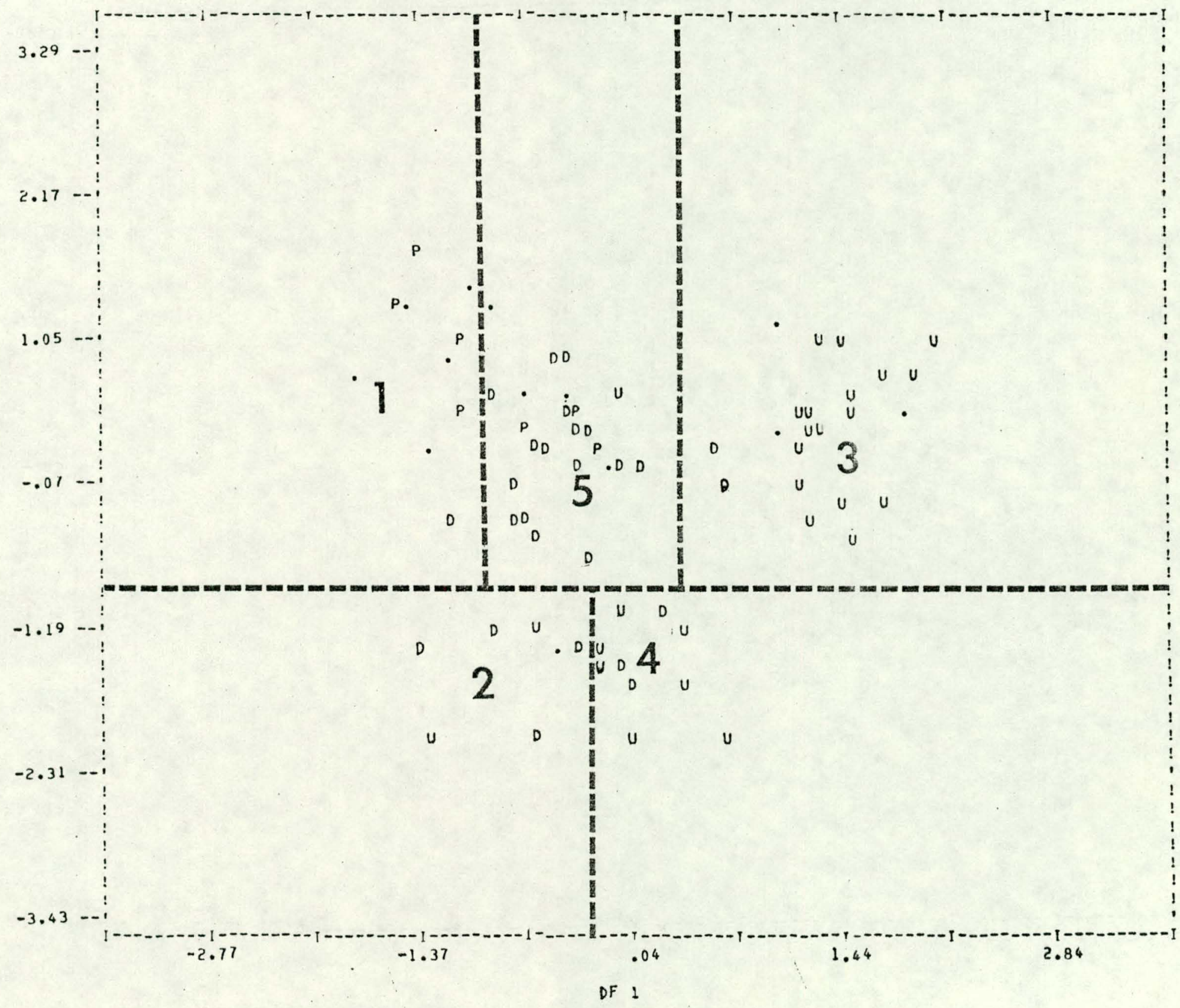

Fig \&, BNL 4-216-80 
DF 2

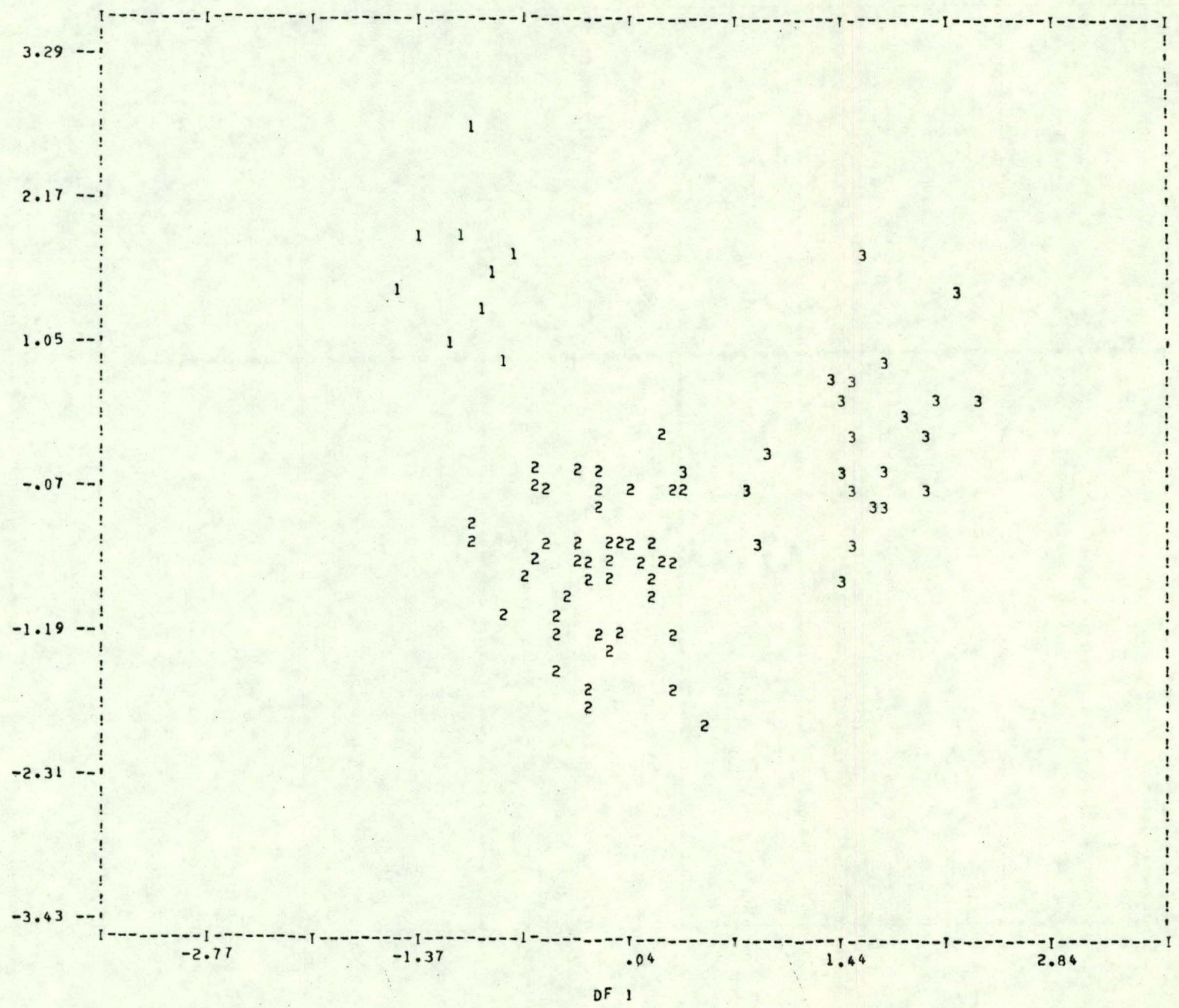

Fig 10, BN< 4-222-80 
DF 2

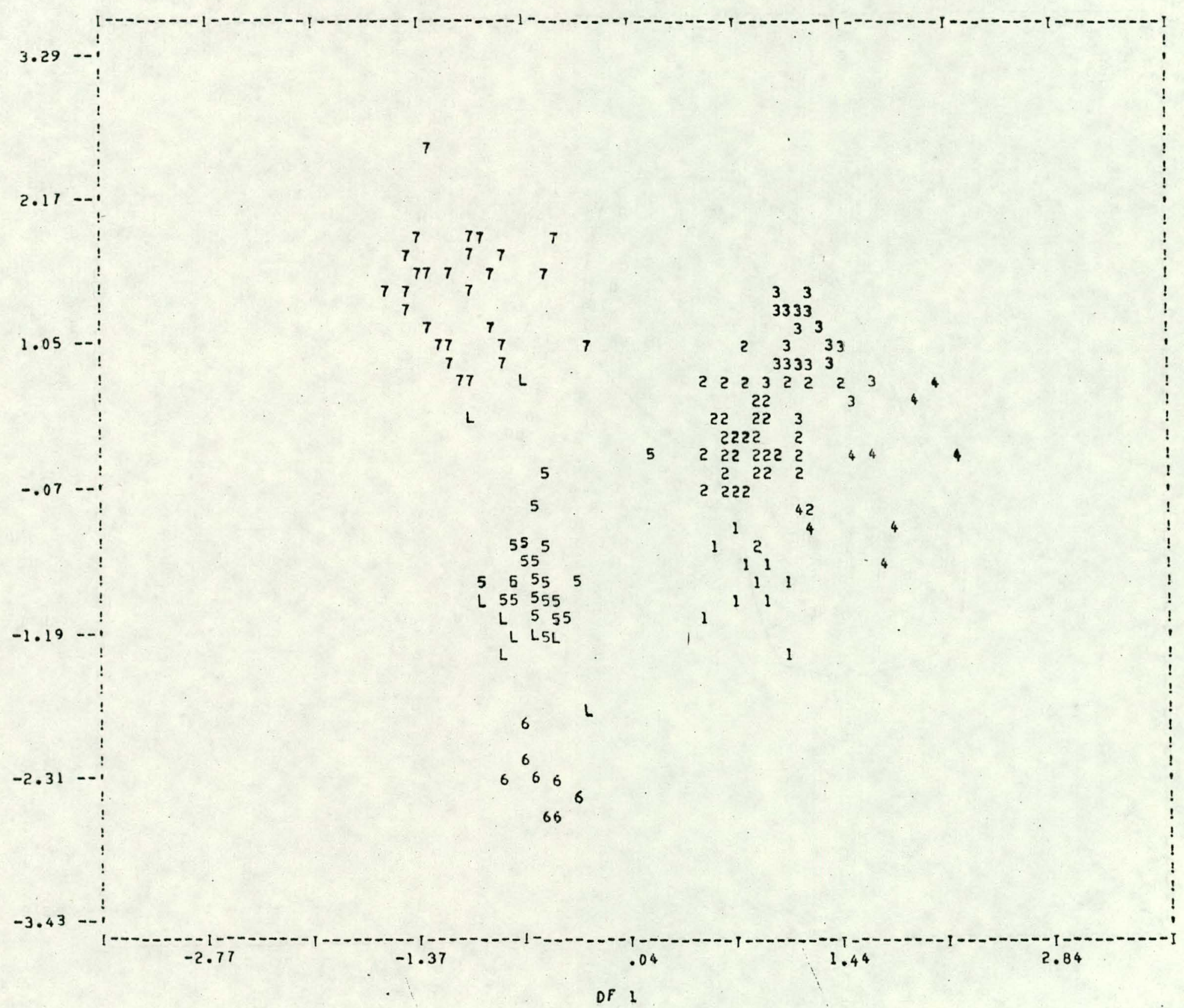

Fis II. BNL 4-214-80 
DF 2

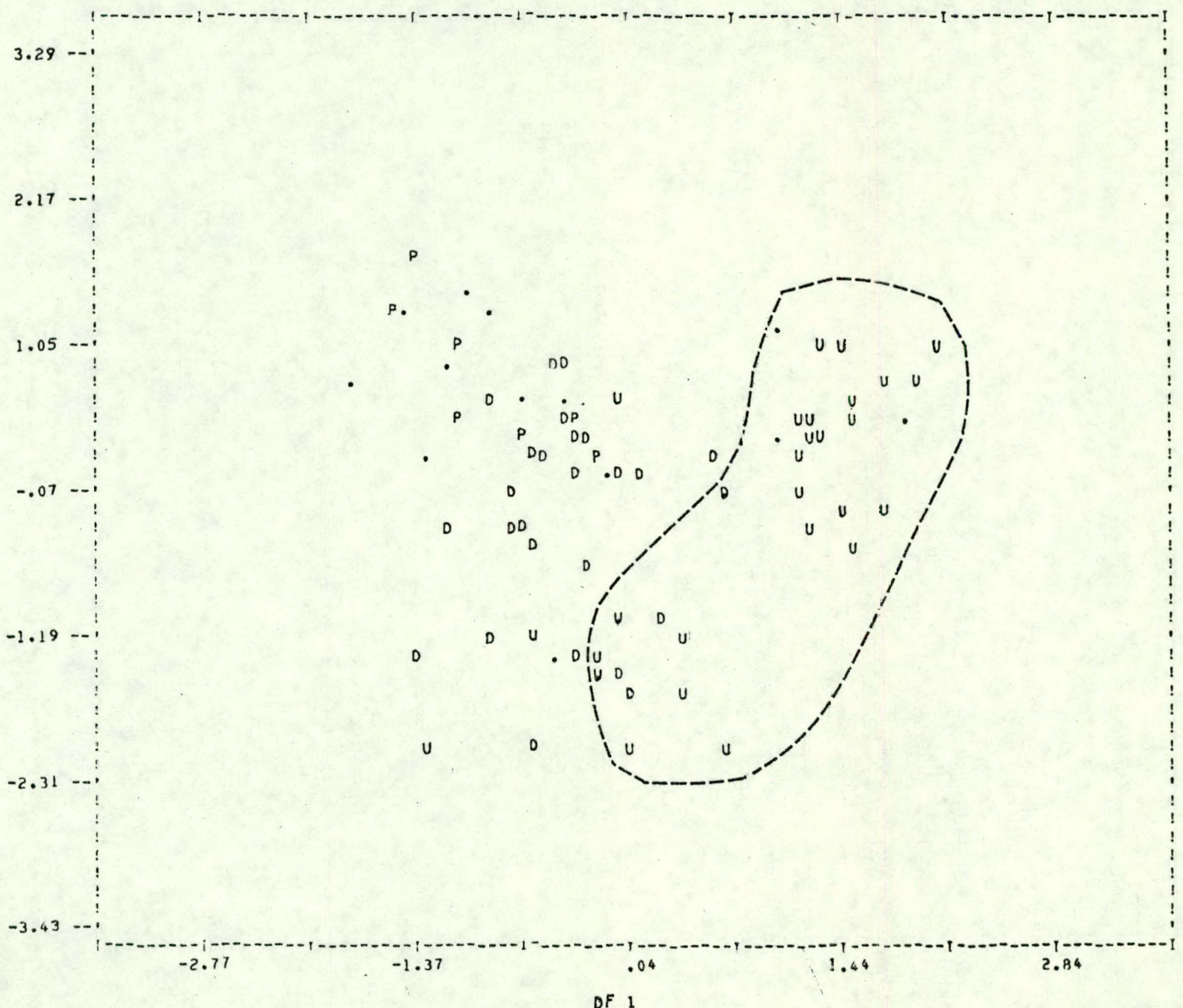

Fis 12, BNL 4-215-80 
DF 2

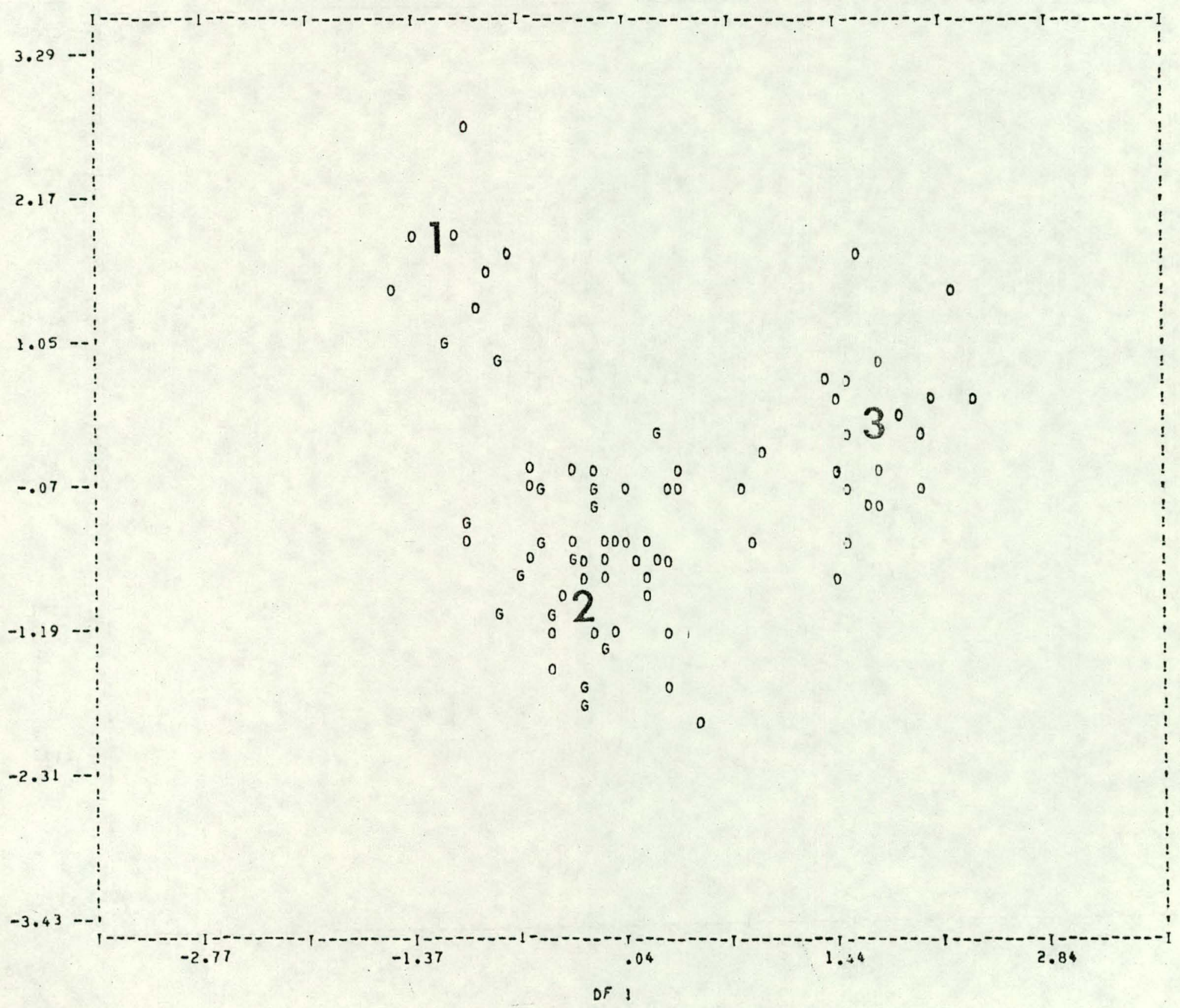

Fig $13, B N<4-223-80$ 


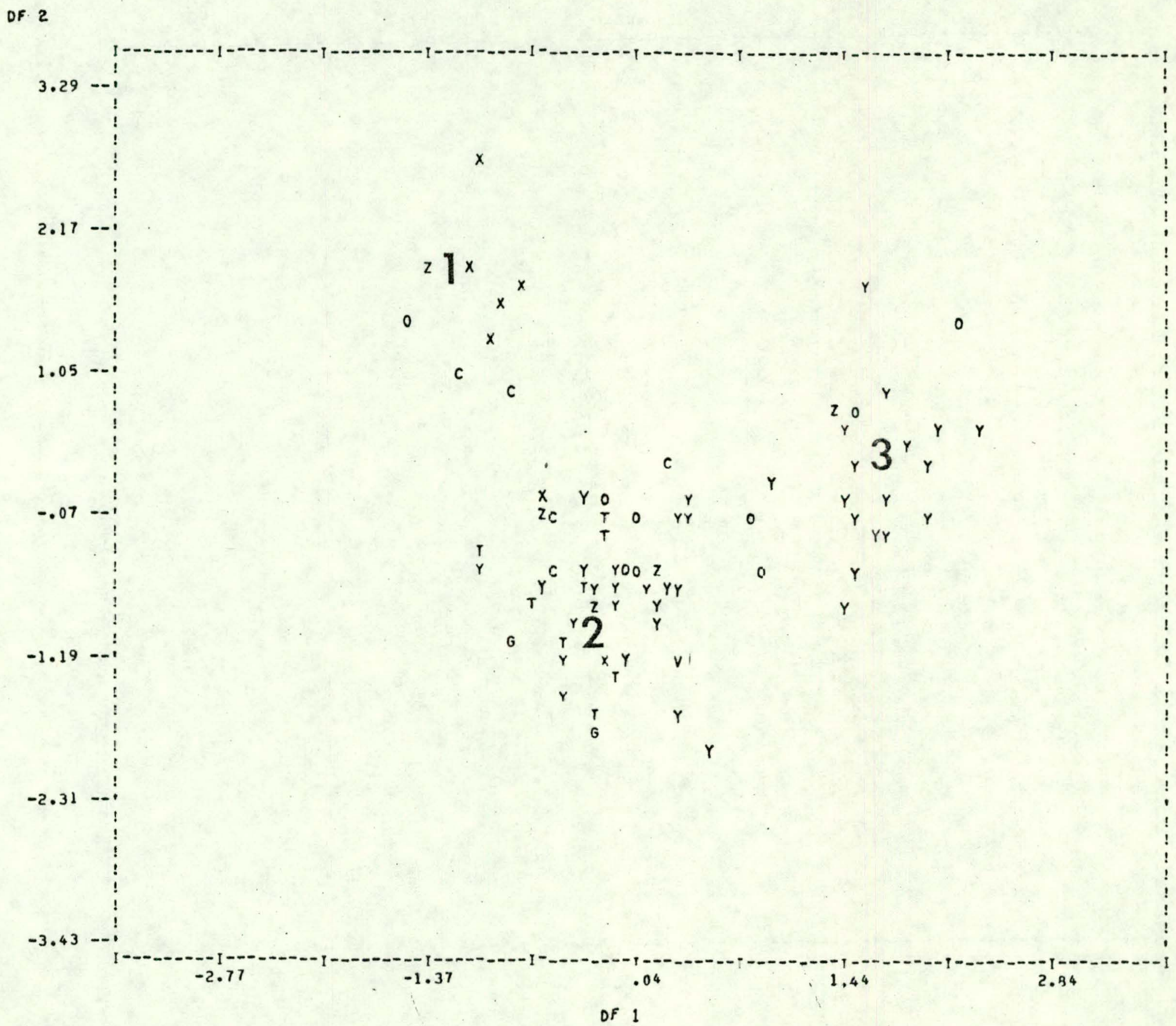

Fig 14, PNL 4-218-80 
DF 2

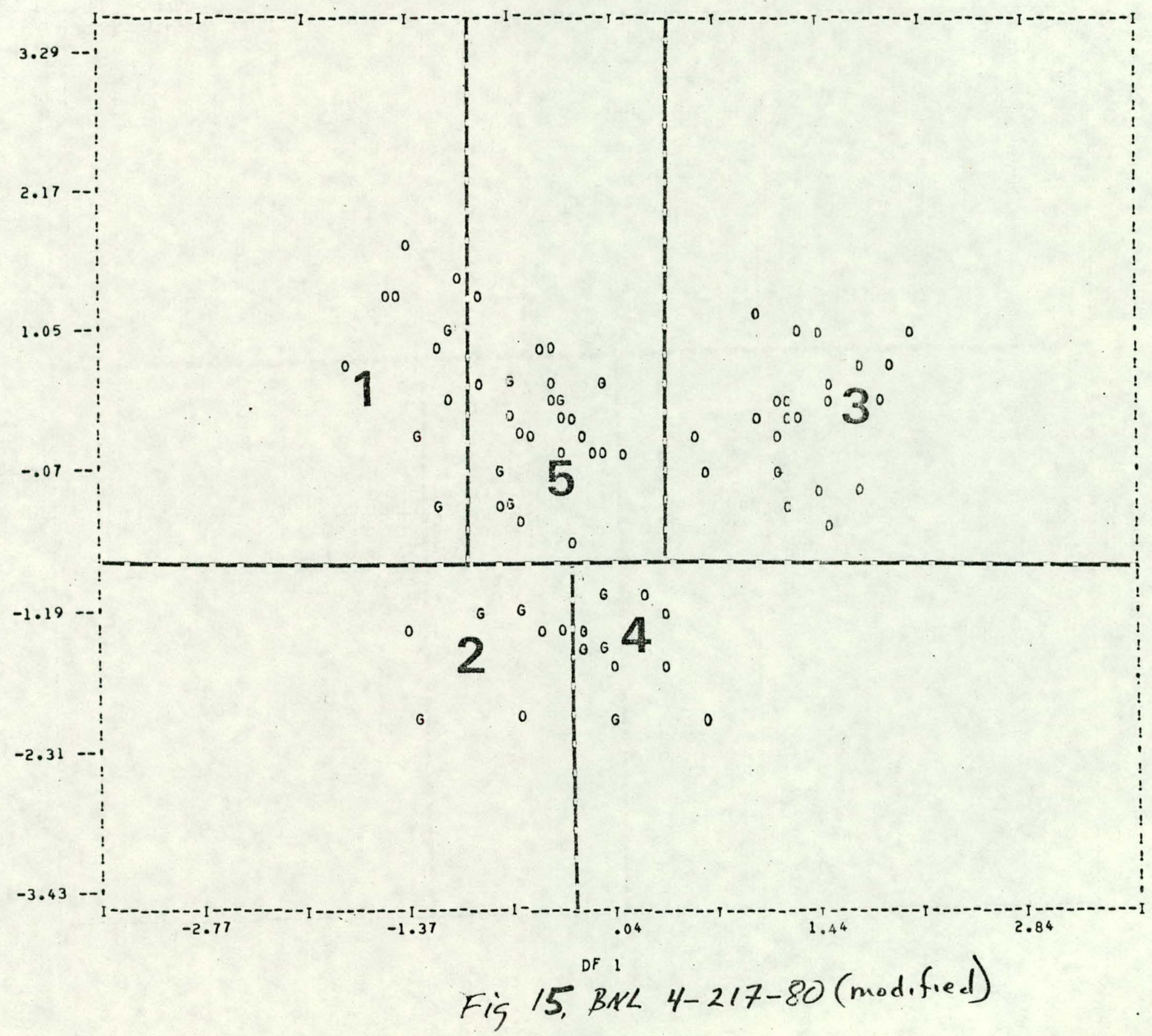


DF 2

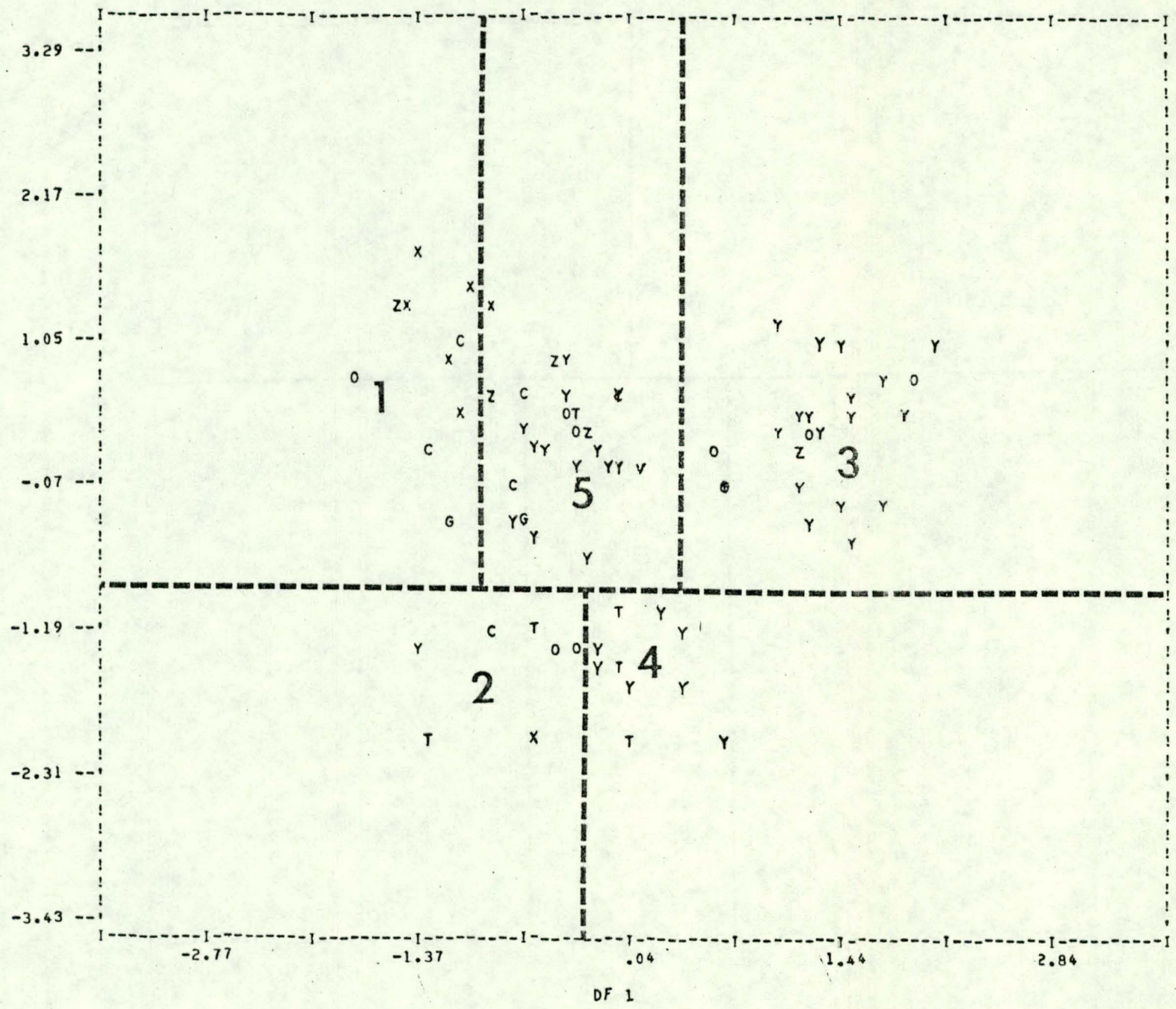

Fis 16, BNL 4-229-80 
DF 2

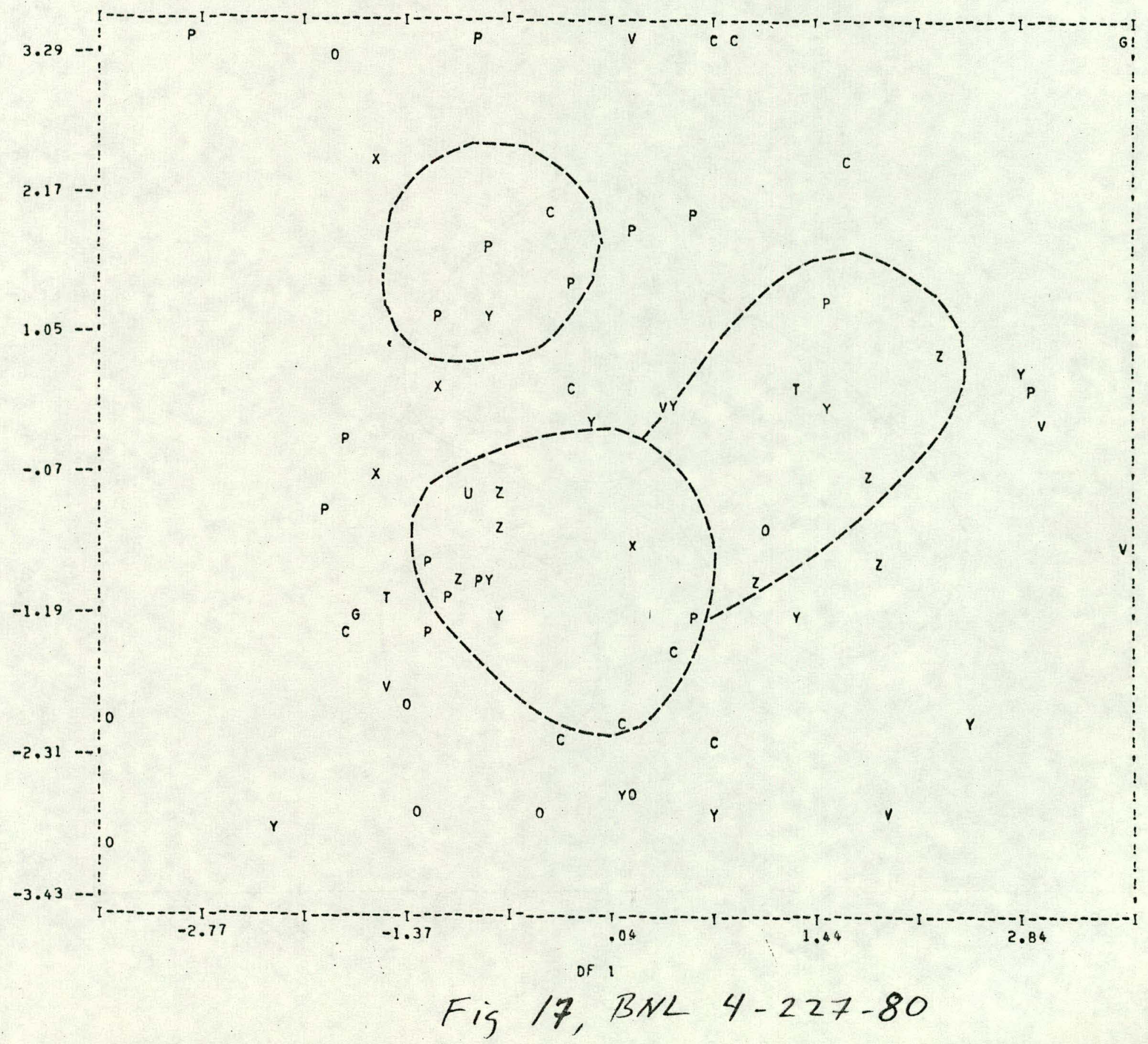


DF 2

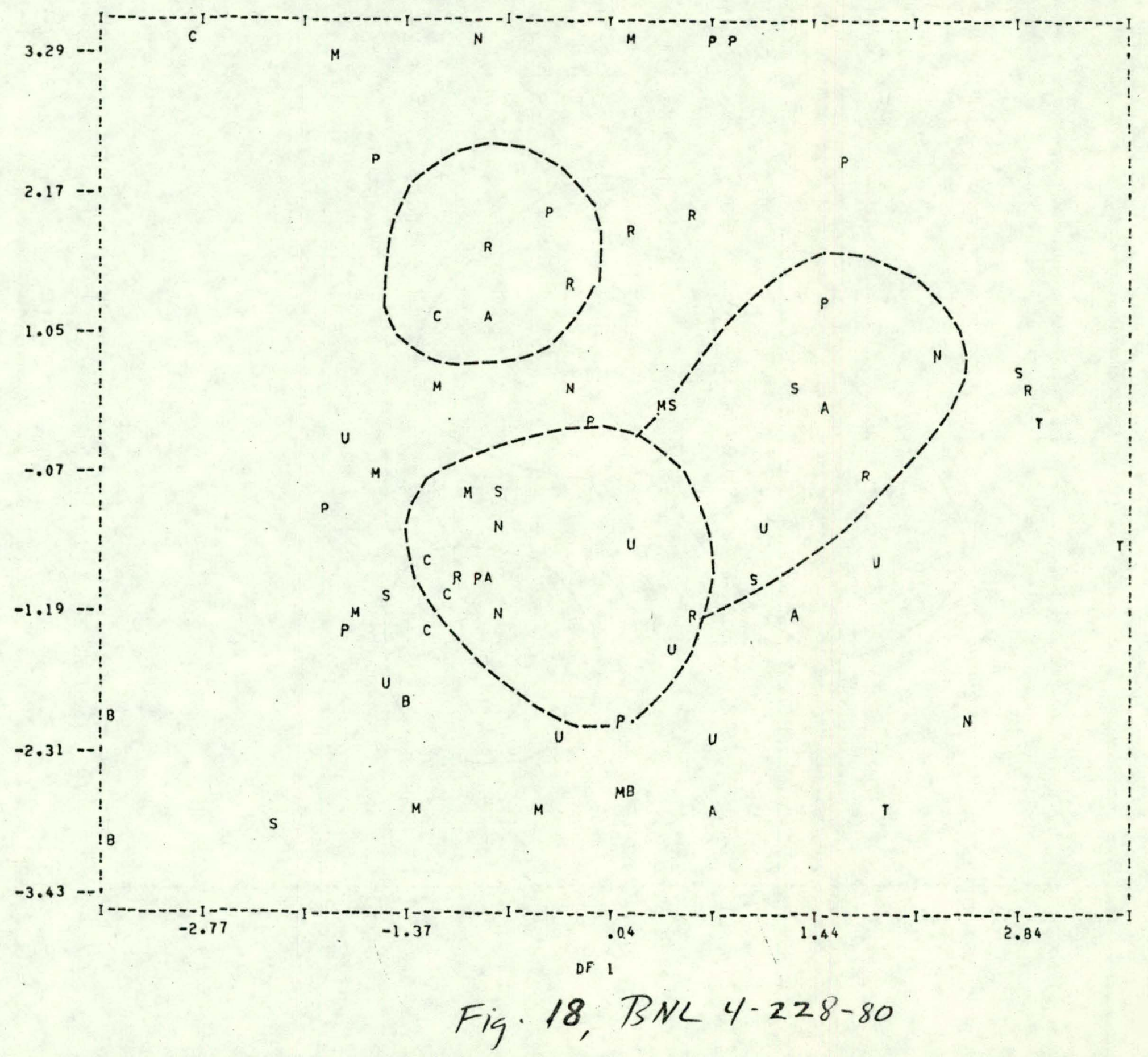


DF 2

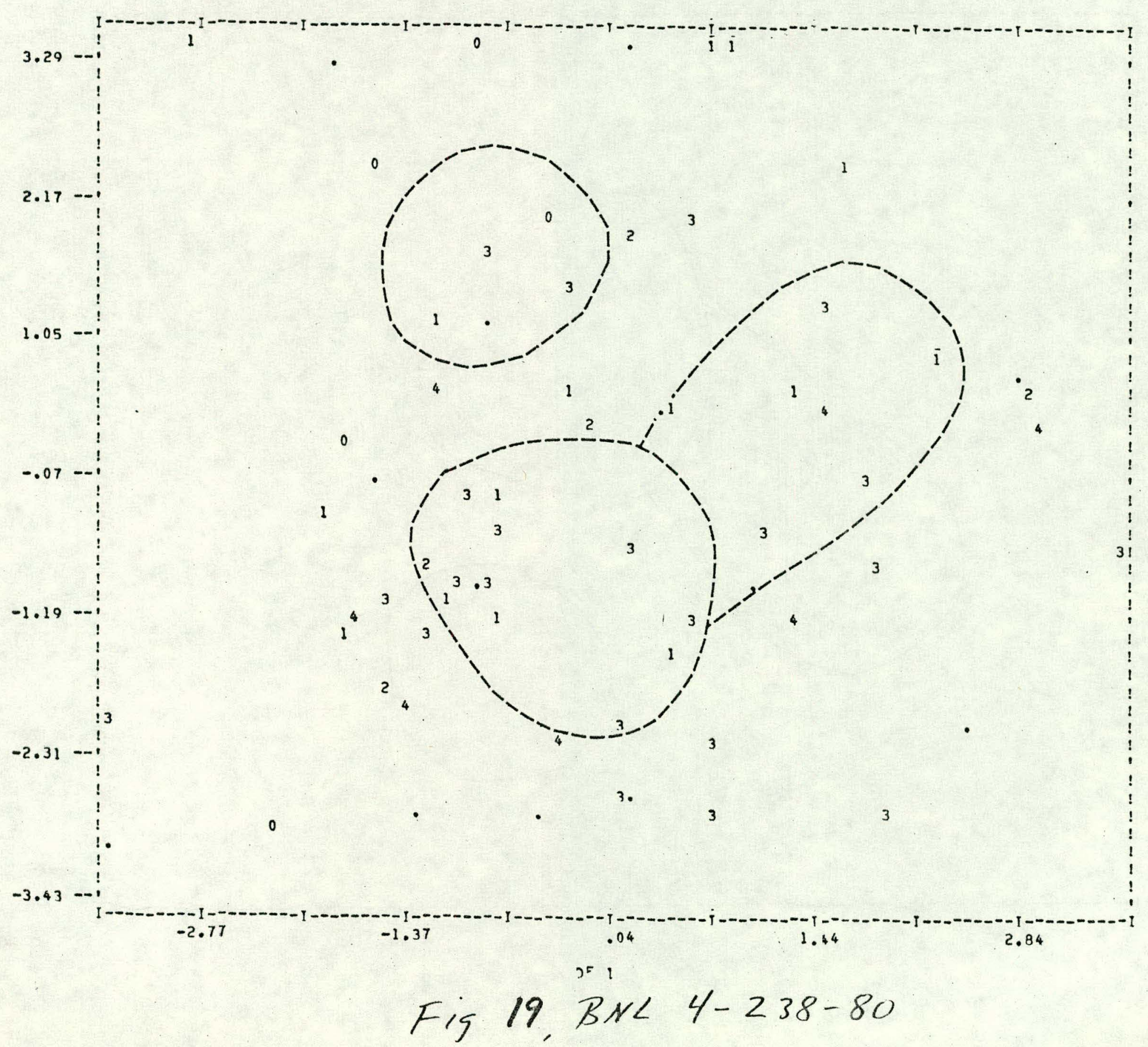


DF 2

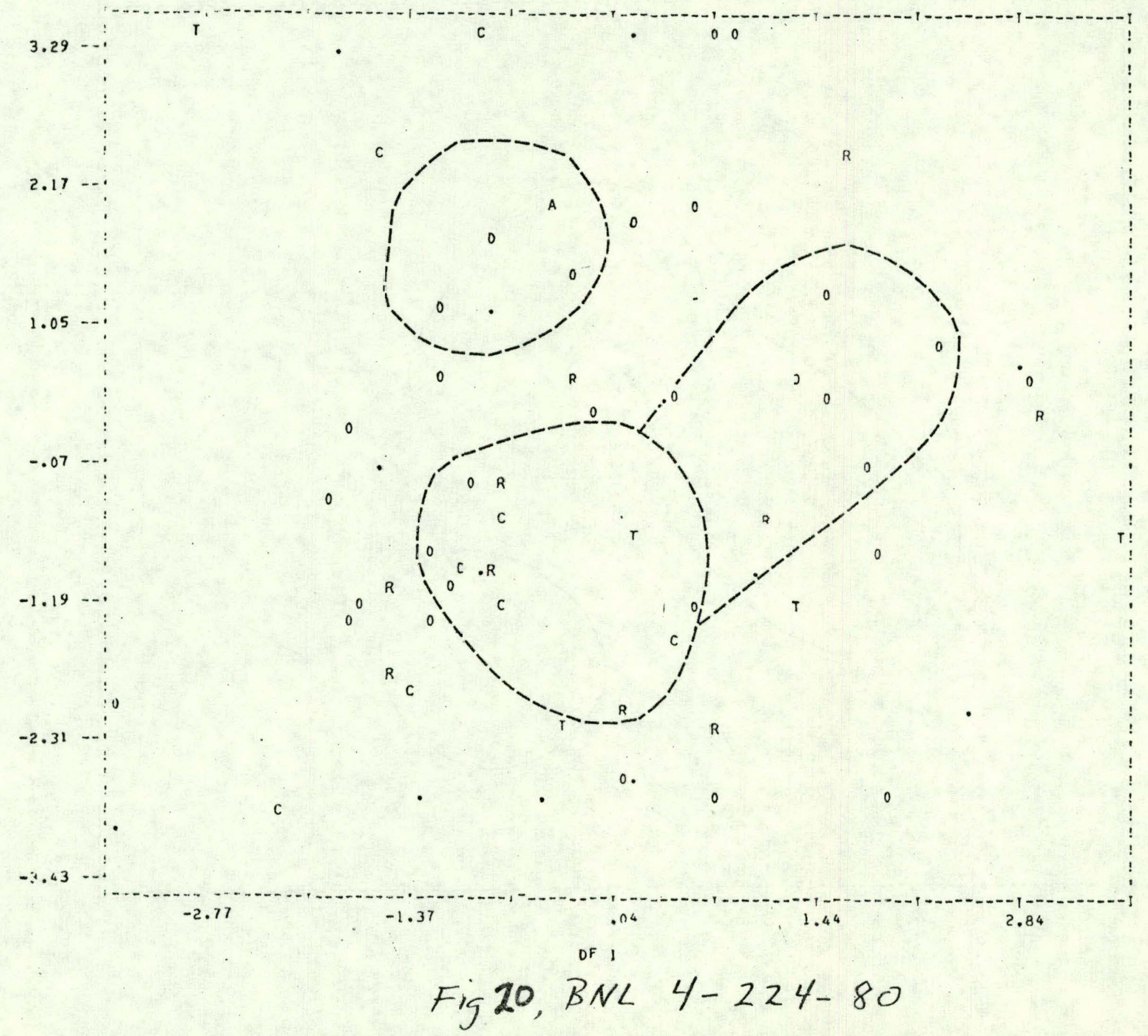




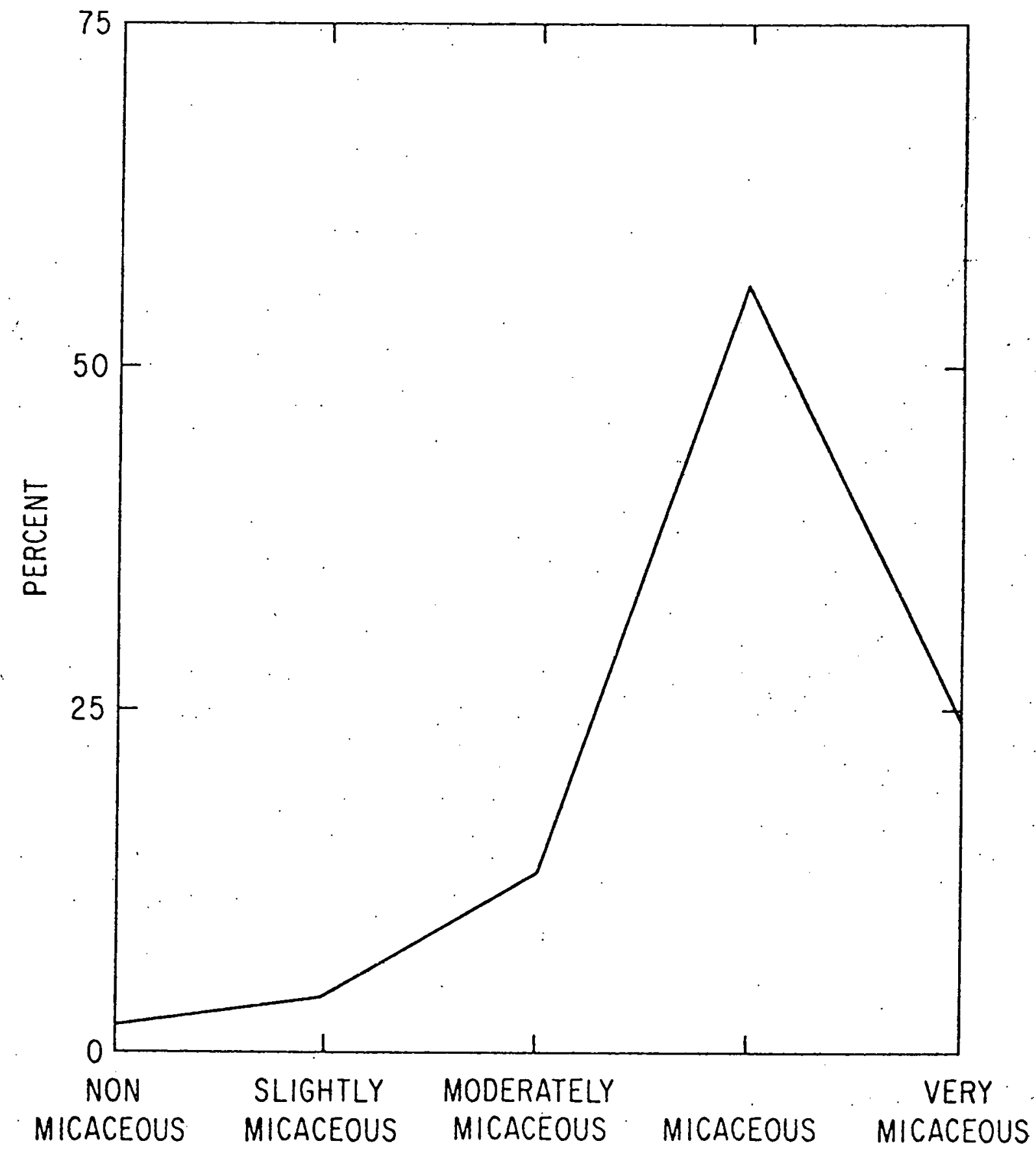

Fig 21, BNL 4-231-80 


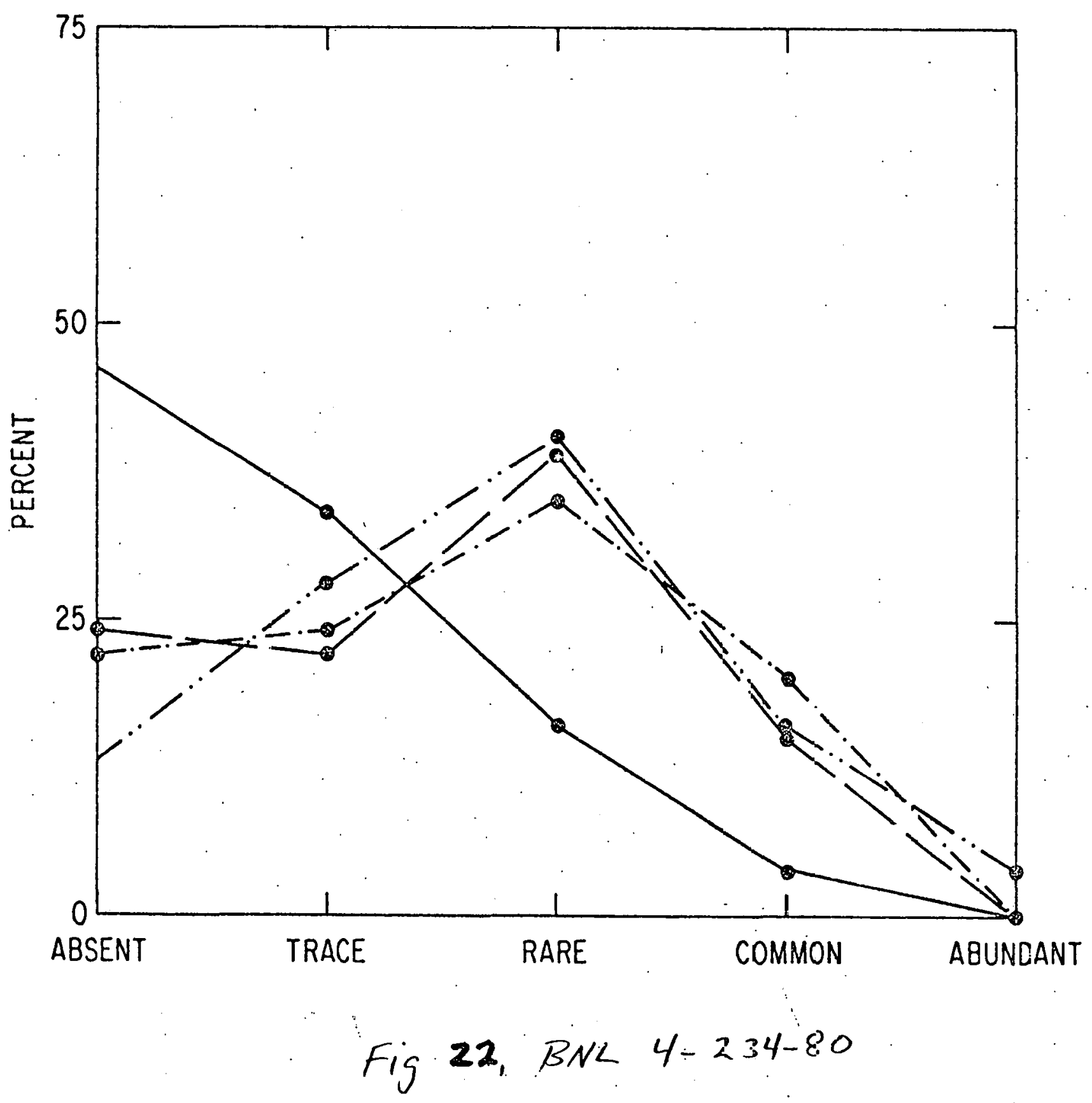




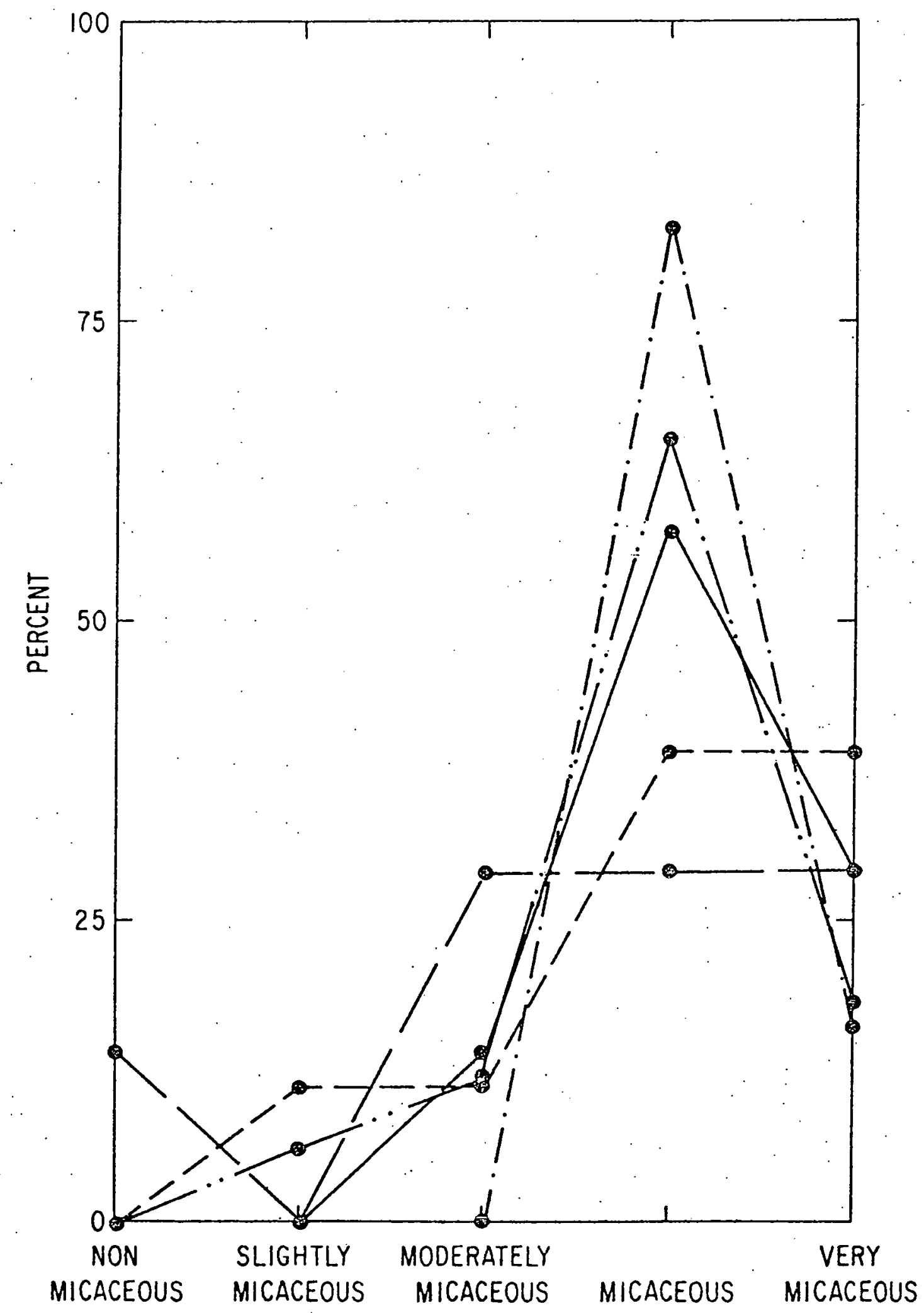

Fig 23, BNL 4-23?-80 


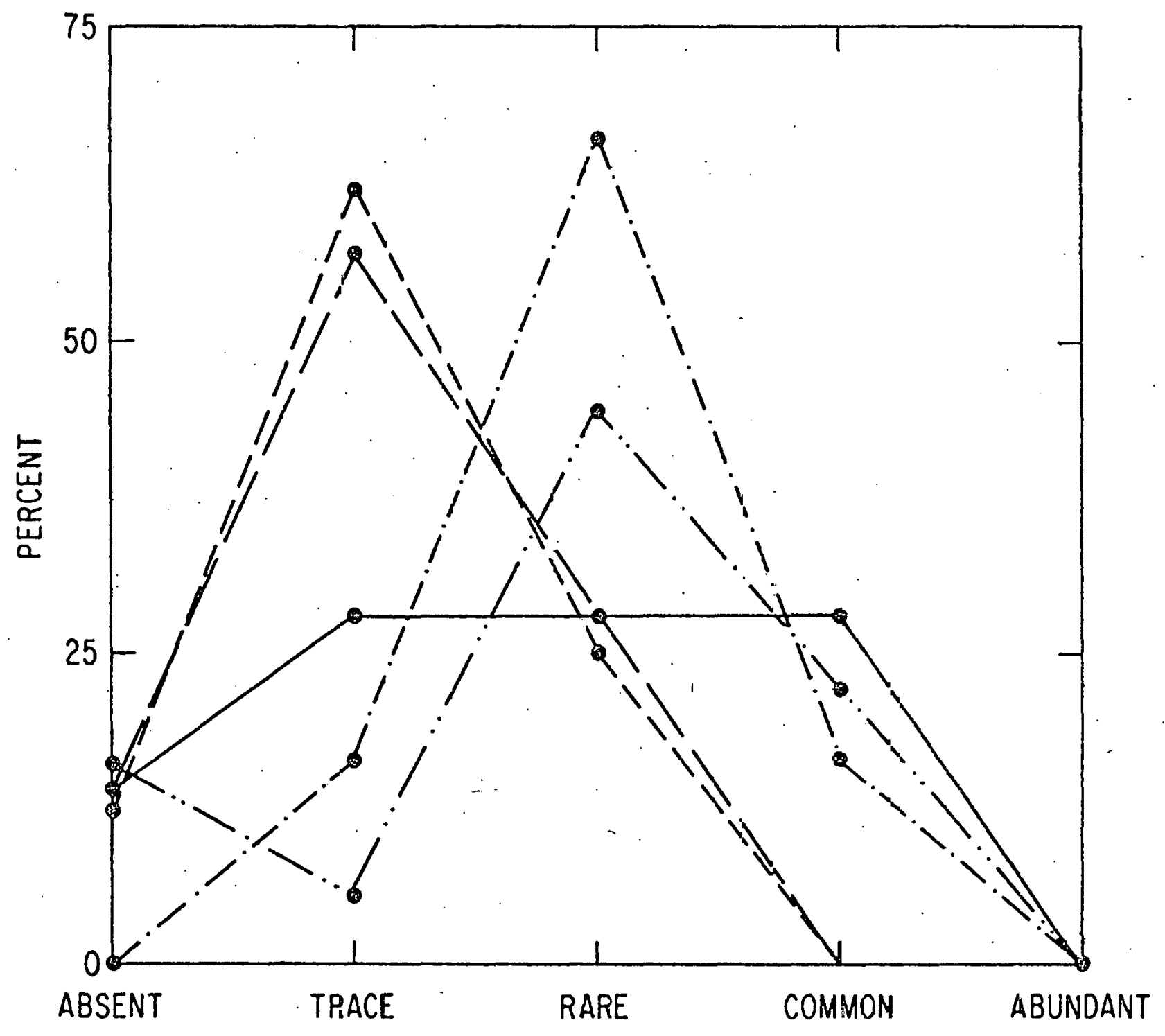

Fig $24 . \quad B N L$ 4-235-80 


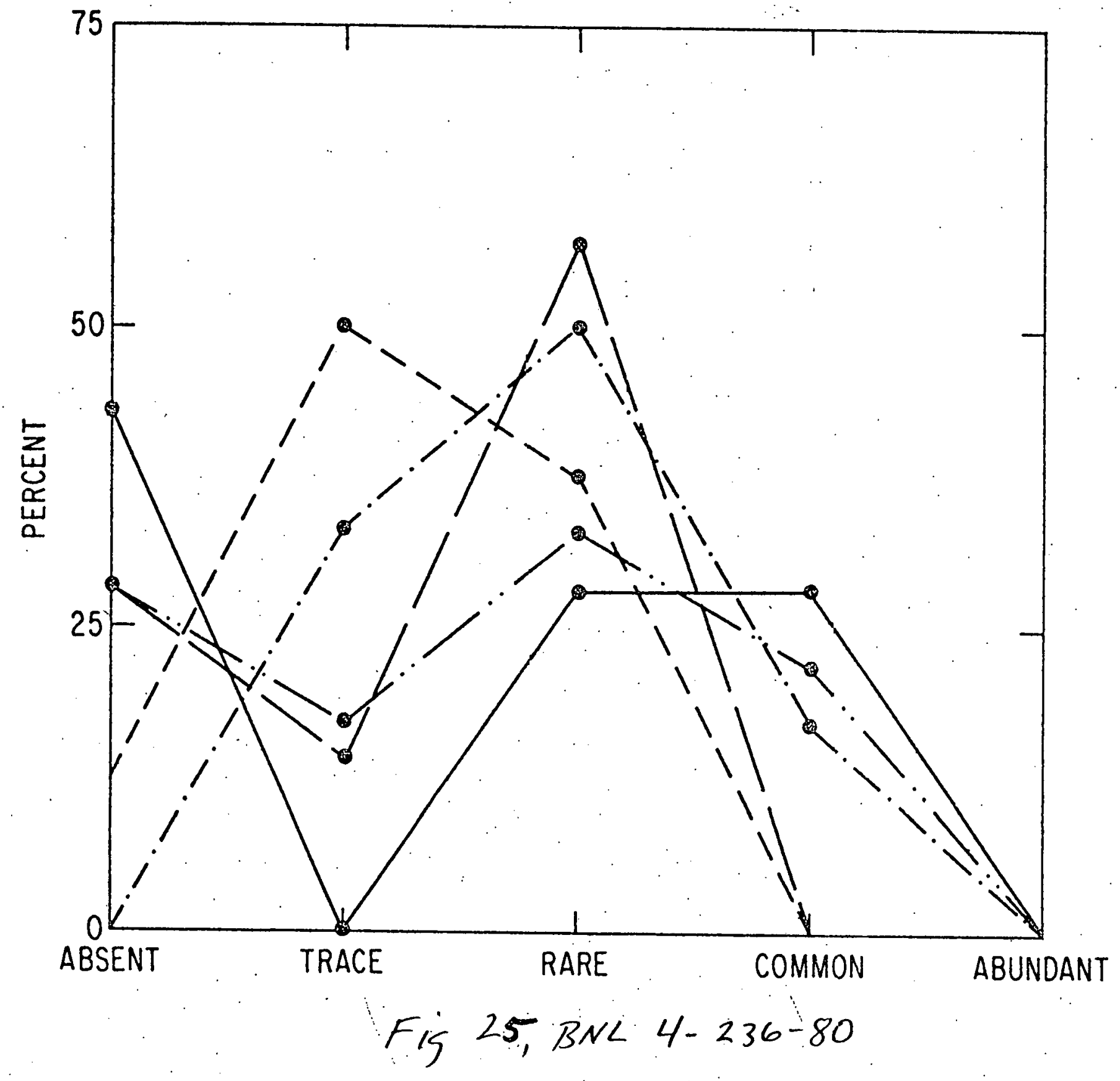




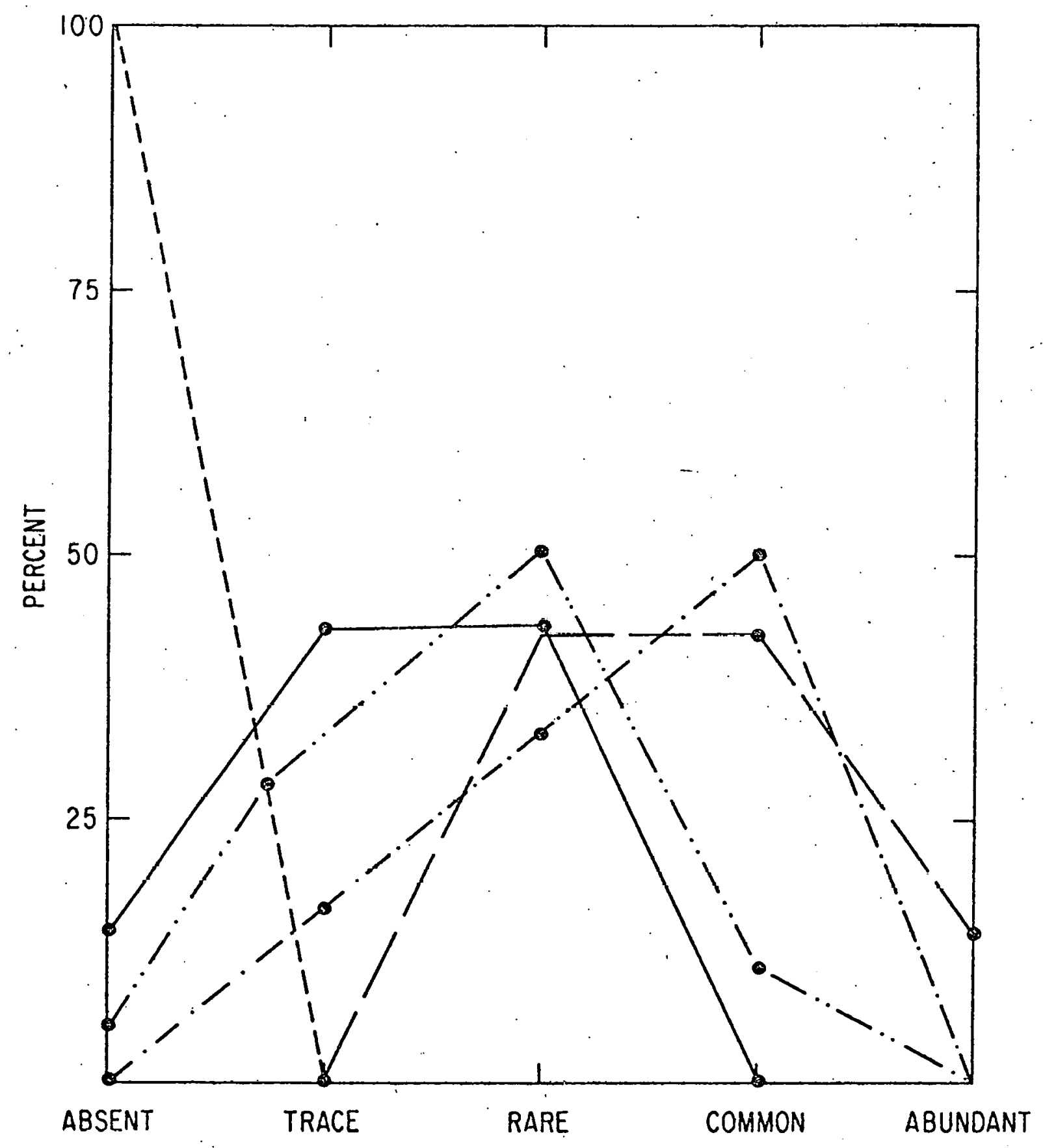

Fig. 26, BNL 4-233-80 


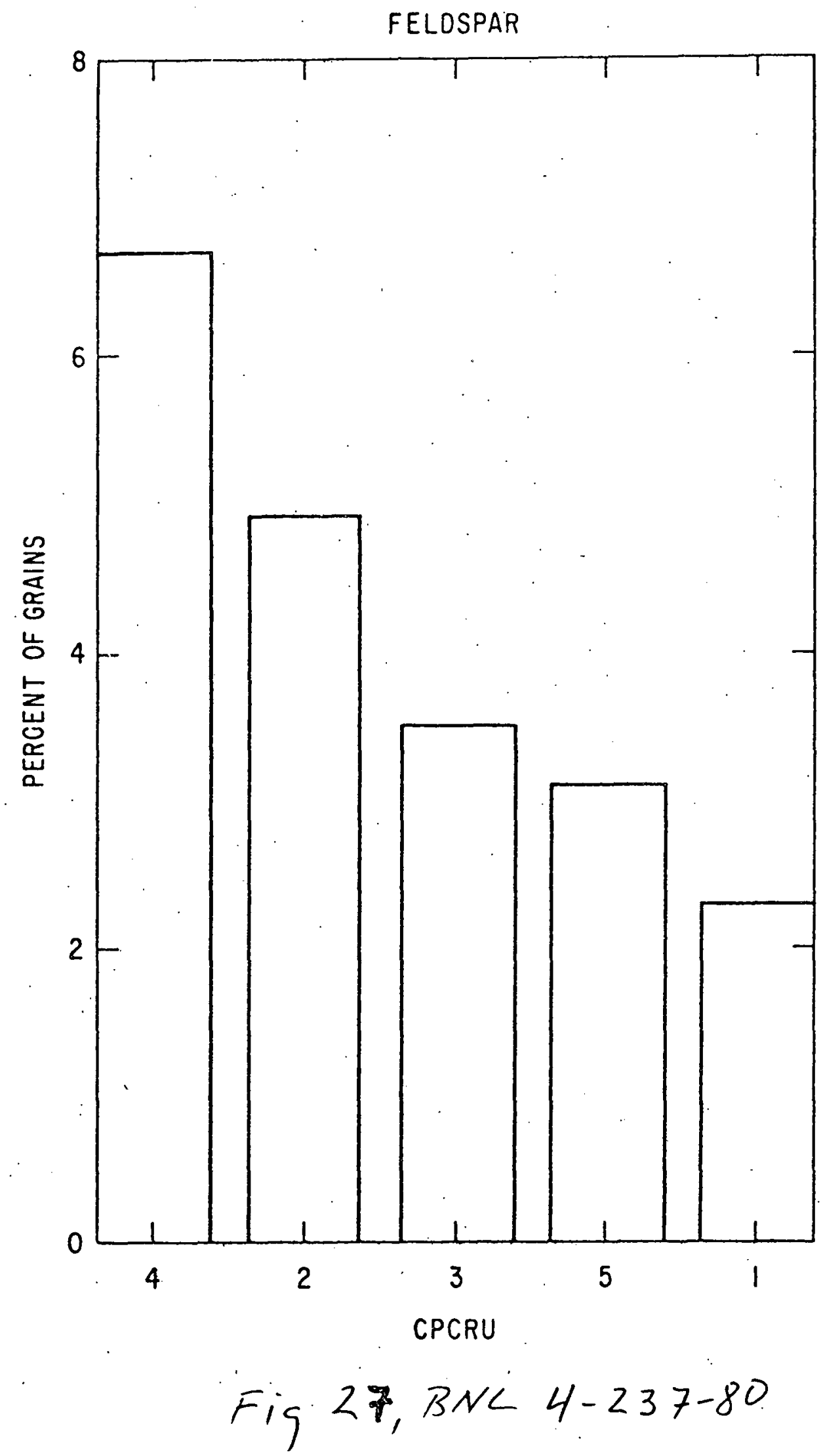




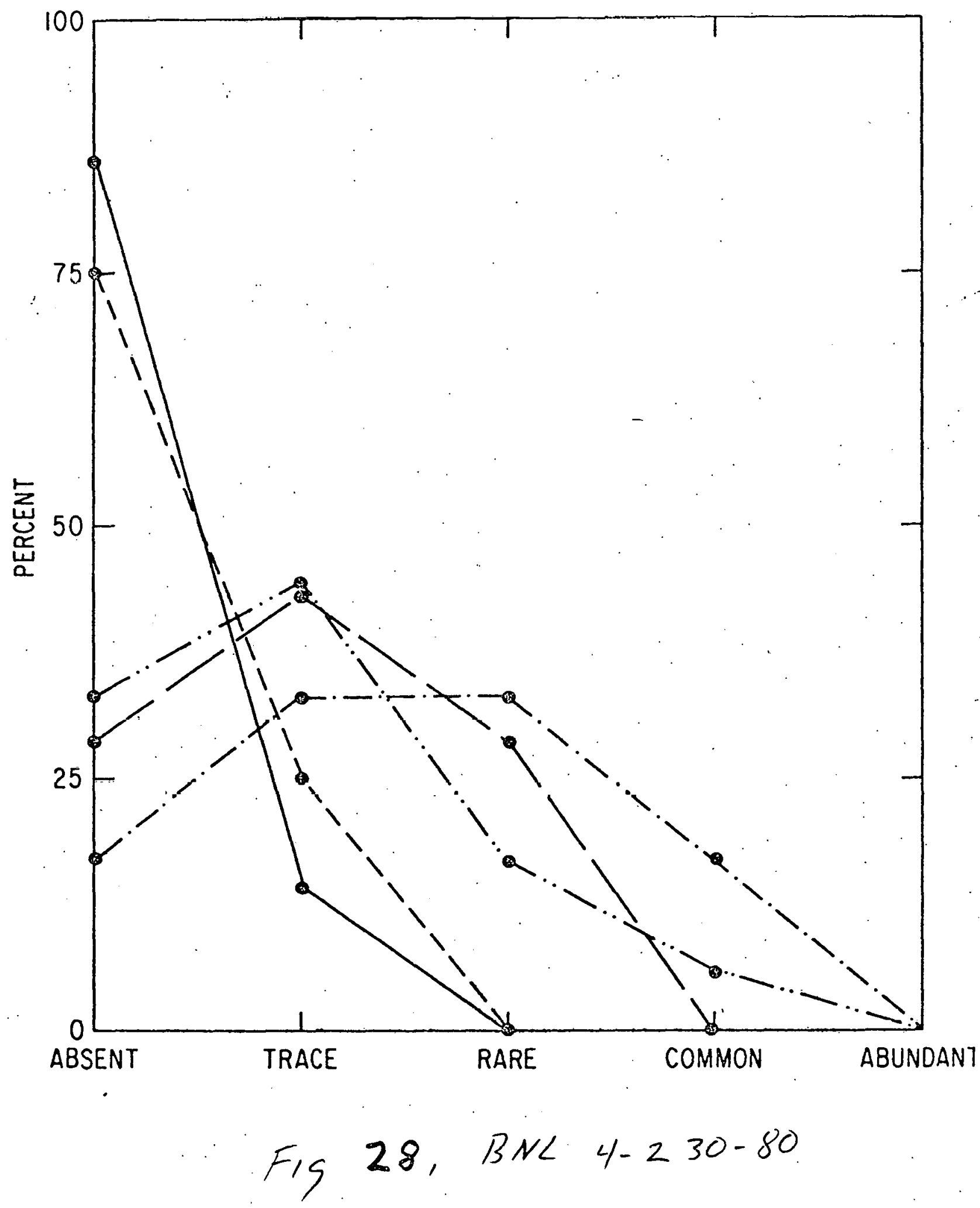




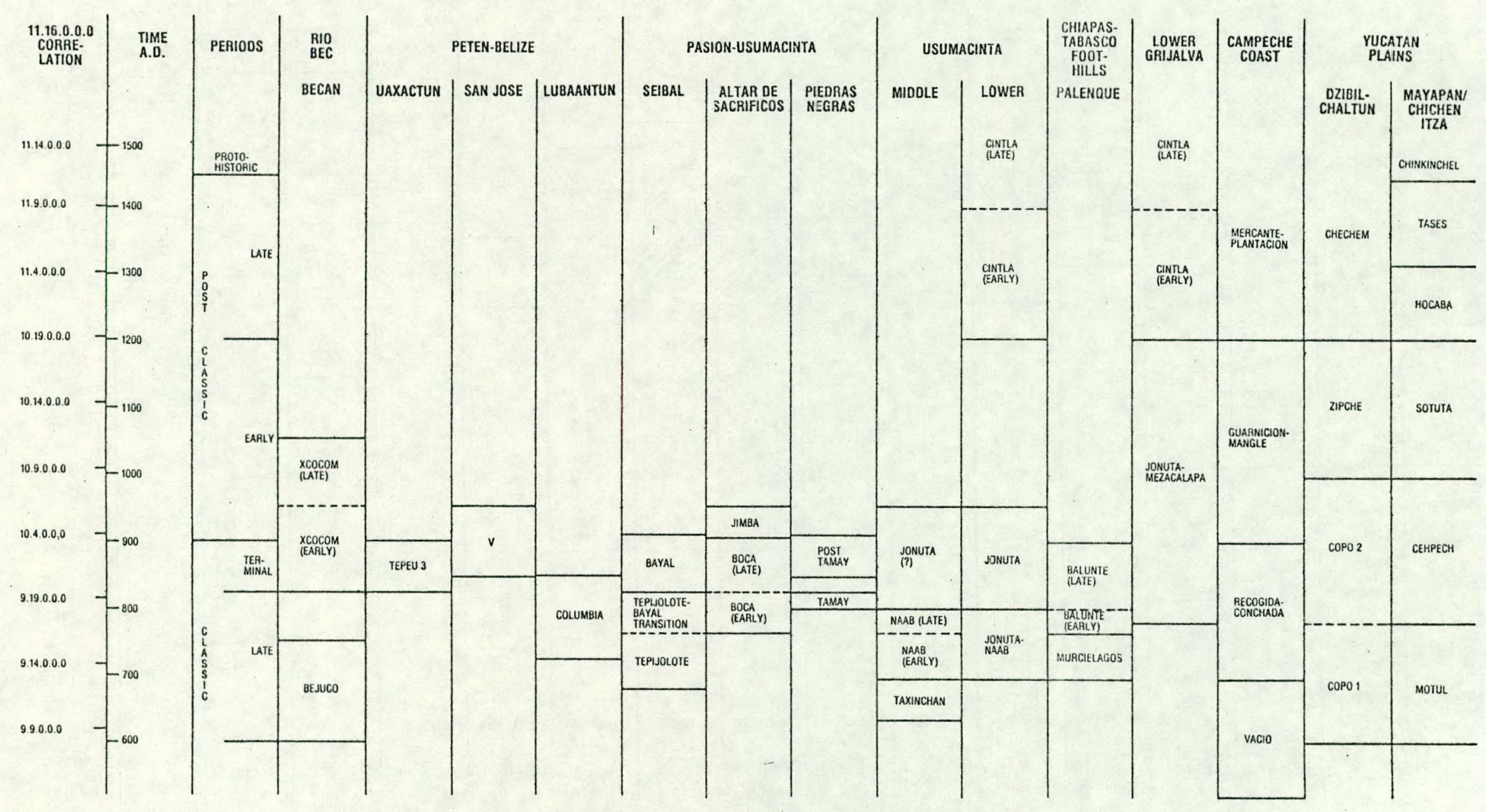

Fig. 29 BNL 4-806-80 


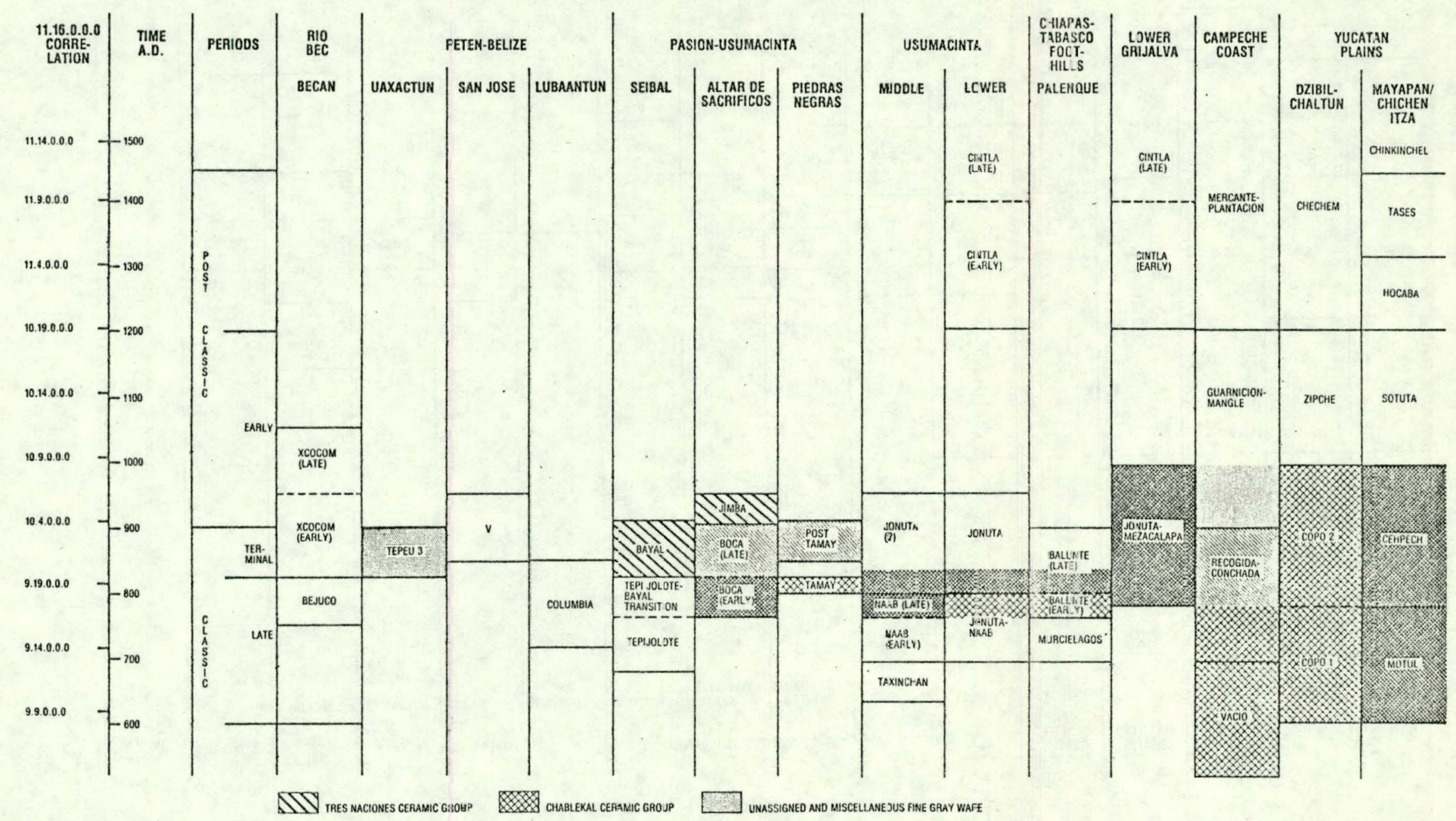

Fig.30, BNL 4-808-80 


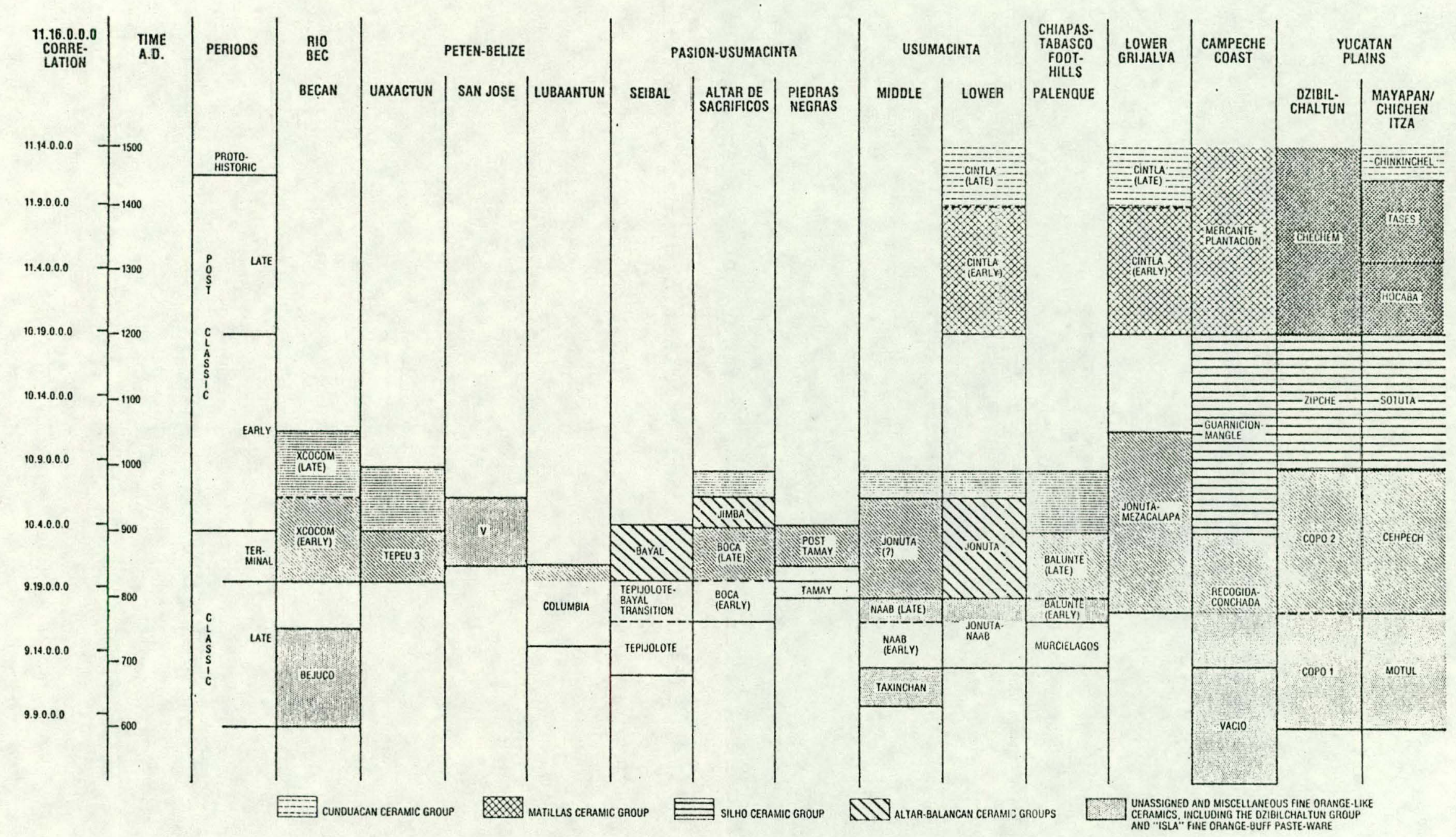

Fig. 31, BNL 4-807-80 


$$
\begin{aligned}
& =94 \\
& 76-27 \\
& F / 9.71379
\end{aligned}
$$

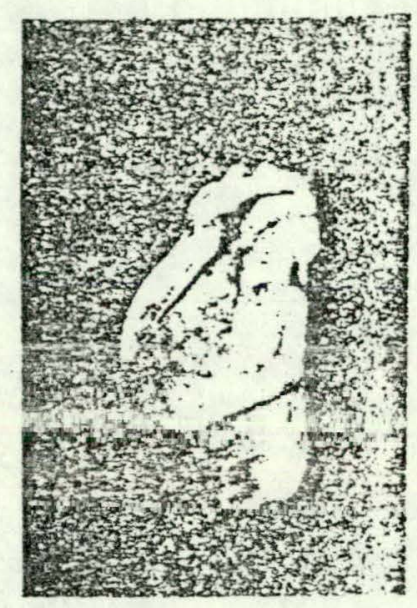

Figure 32. Fine orange paste figurine. Palenque, Specimen

\# 1174, Early Classic and Preclassic deposit, unplaced in CPCRUs. 


$$
\begin{aligned}
& \text { F } 3 \\
& \text { CK } 39 \\
& \text { TS Y4 }
\end{aligned}
$$

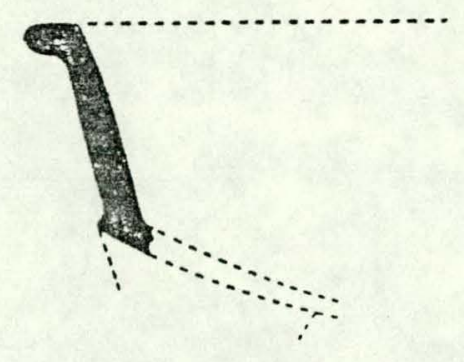

a

$$
\begin{aligned}
& F 25 \\
& T=46 \Rightarrow 94 \\
& T S 730
\end{aligned}
$$

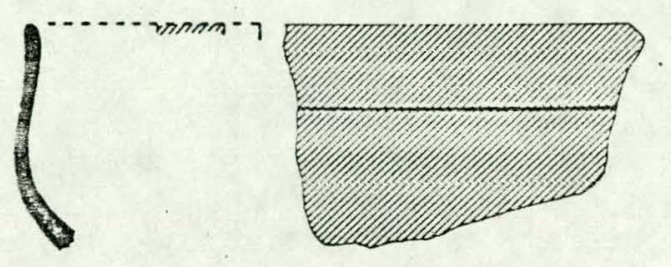

b
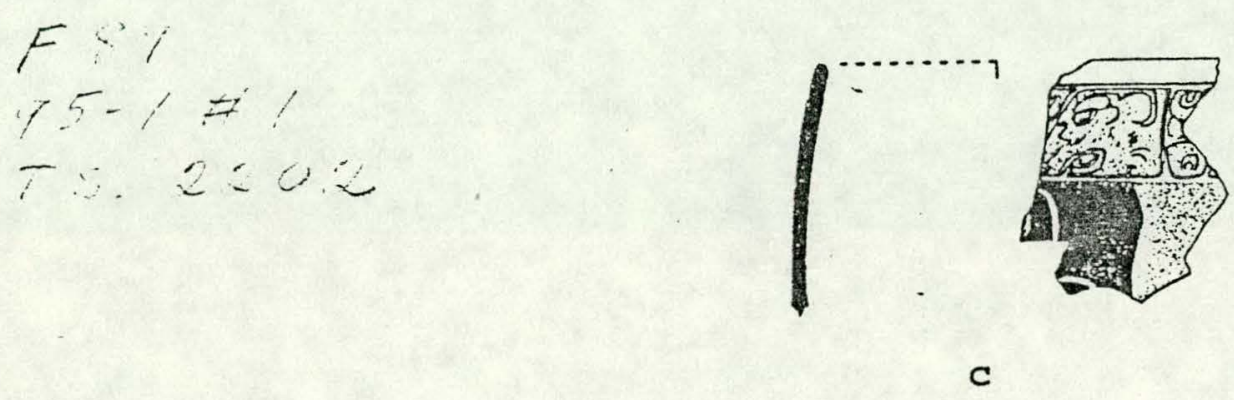

Figure 33. Early fine paste including Fine orange Ware (b, c). a. Tortuguero, Specimen \# 43, black (compare Tzakol sharp Z-angle bowls). Tortuguero compositional group; b. Trinidad, Specimen \# 25, unnamed incised orange, Taxinchan Ceramic Complex, specimen

unplaced in CPCRUs; c. Palenque, $\mathbf{A}$ \# black-and-white-on-orange with classic style glyph band, Murcielagos/early-facet Balunte Ceramic Complex, unplaced in CPCRUs. One-third scale. 


\section{F $5 \% 3$ \\ $2-56 \# 7$ \\ T5. 34}

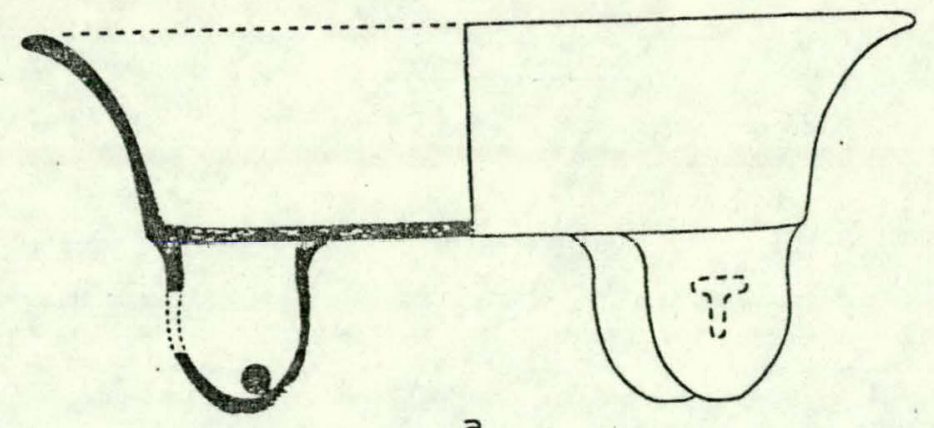

a
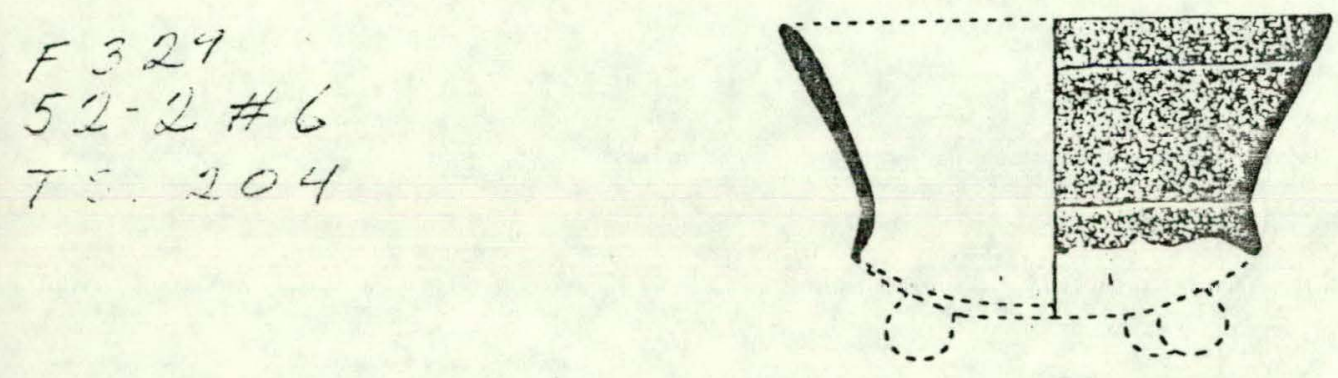

$\mathrm{b}$

$$
\begin{aligned}
& \text { Fri } \\
& 80.1 \# 71 \\
& 7 \therefore 2211
\end{aligned}
$$

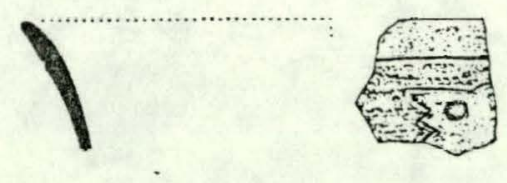

C

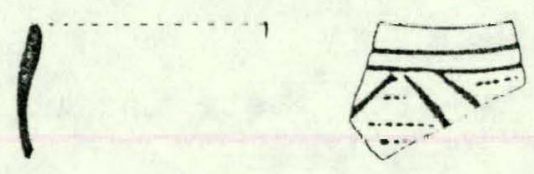

d

Figure 34. Fine Gray Ware, Chablekal Ceramic Group. a-c. Palenque, Balunte Ceramic Complex; d. Tierra Blanca, Naab Ceramic Complex. a. Specimen \# 373, Chablekal Gray Type; b. Specimen \# 329, Chicxulub Incised Type; c. Specimen \# 722, Telchac Composite Type; d. Specimen \# 36, Telchac Composite Type. a. CPCRU $1 ; b-d$. Unplaced in CPCRUs. One-third scale. 


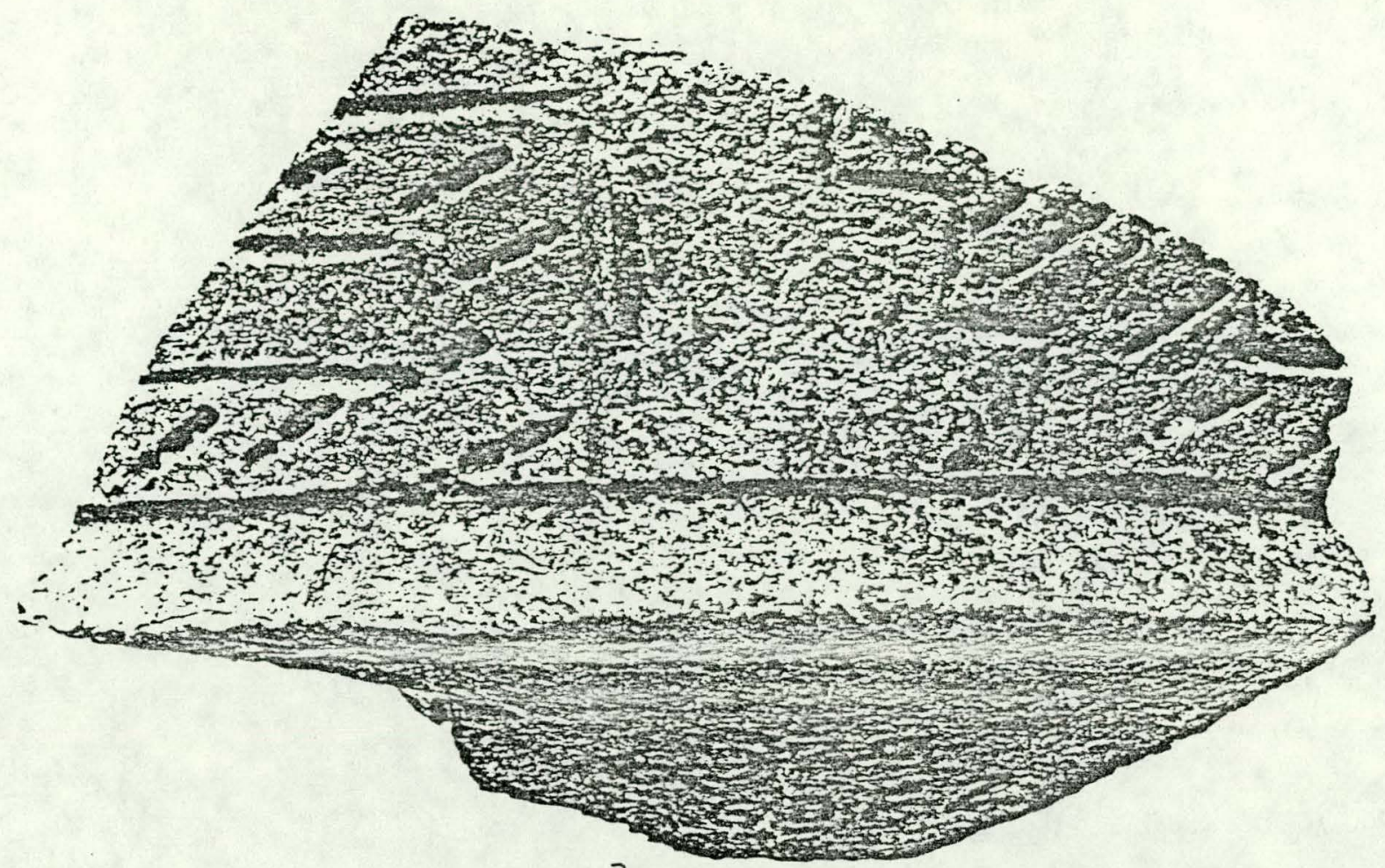

a

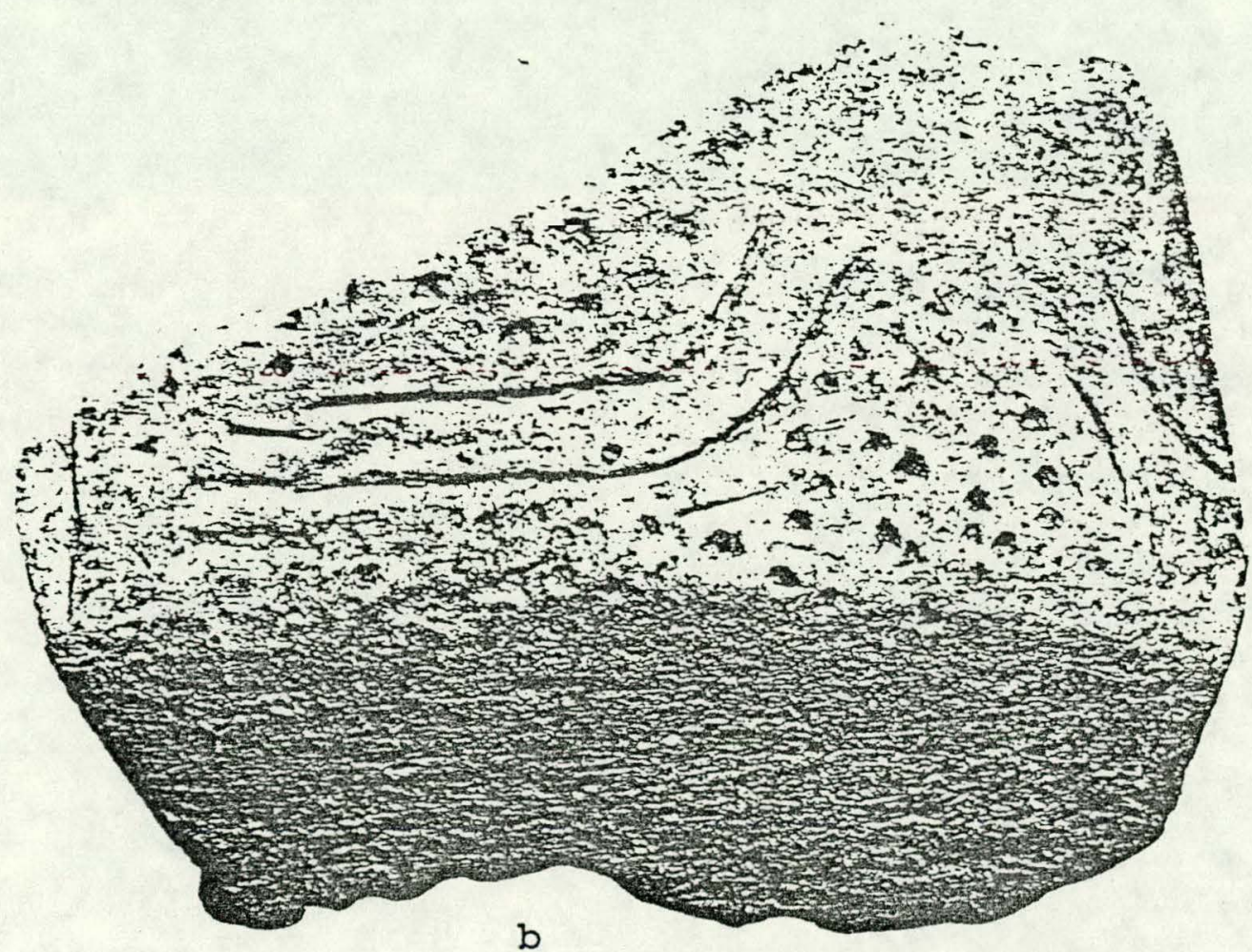

Figure 35. Fine Gray Ware, Chablekal Ceramic Group. a.

Piedras Negras, Specimen \# 322, Telchac Composite Type, Tamay

Ceramic Compiex, CPCRU 5; b. Dzibilchaltun, Specimen \# 1234 ,

Telchac Composite Type, Copo 1 or 2 Ceramic Complex, CPCRU 1. 


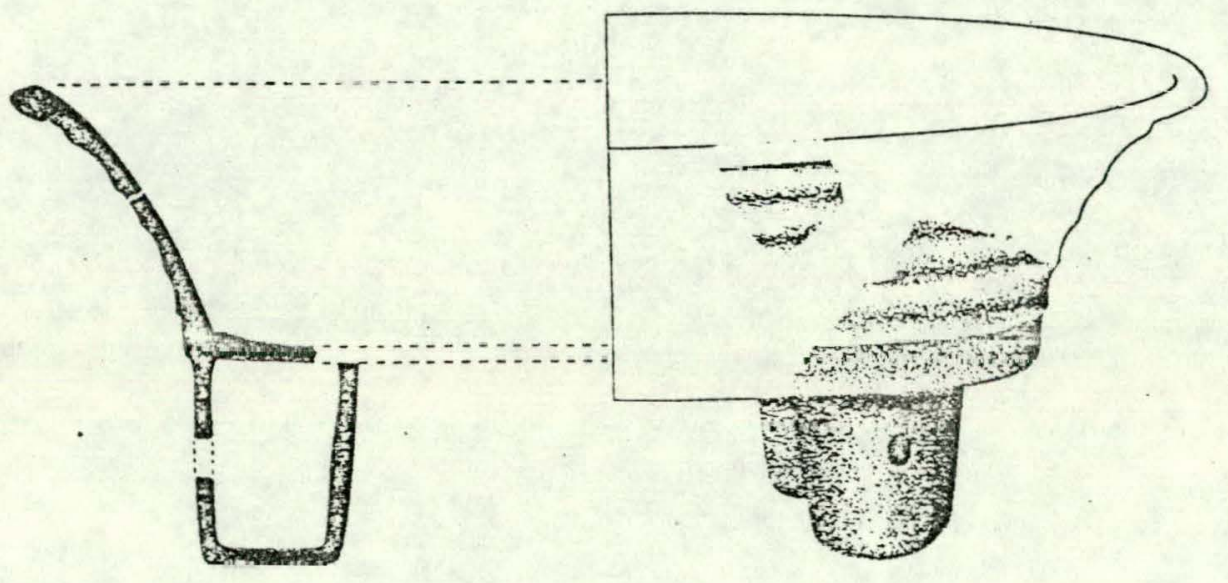

Figure 36. Fine Gray Ware, Chablekal Ceramic Group. Palenque, Specimen \# 84, Cholul Fluted Type, Balunte Ceramic - Complex, unplaced in CPCRUs. One-third scale. 


$$
\begin{gathered}
5: 29 \\
-1-8 \\
\#+4 \\
7 \therefore 204
\end{gathered}
$$

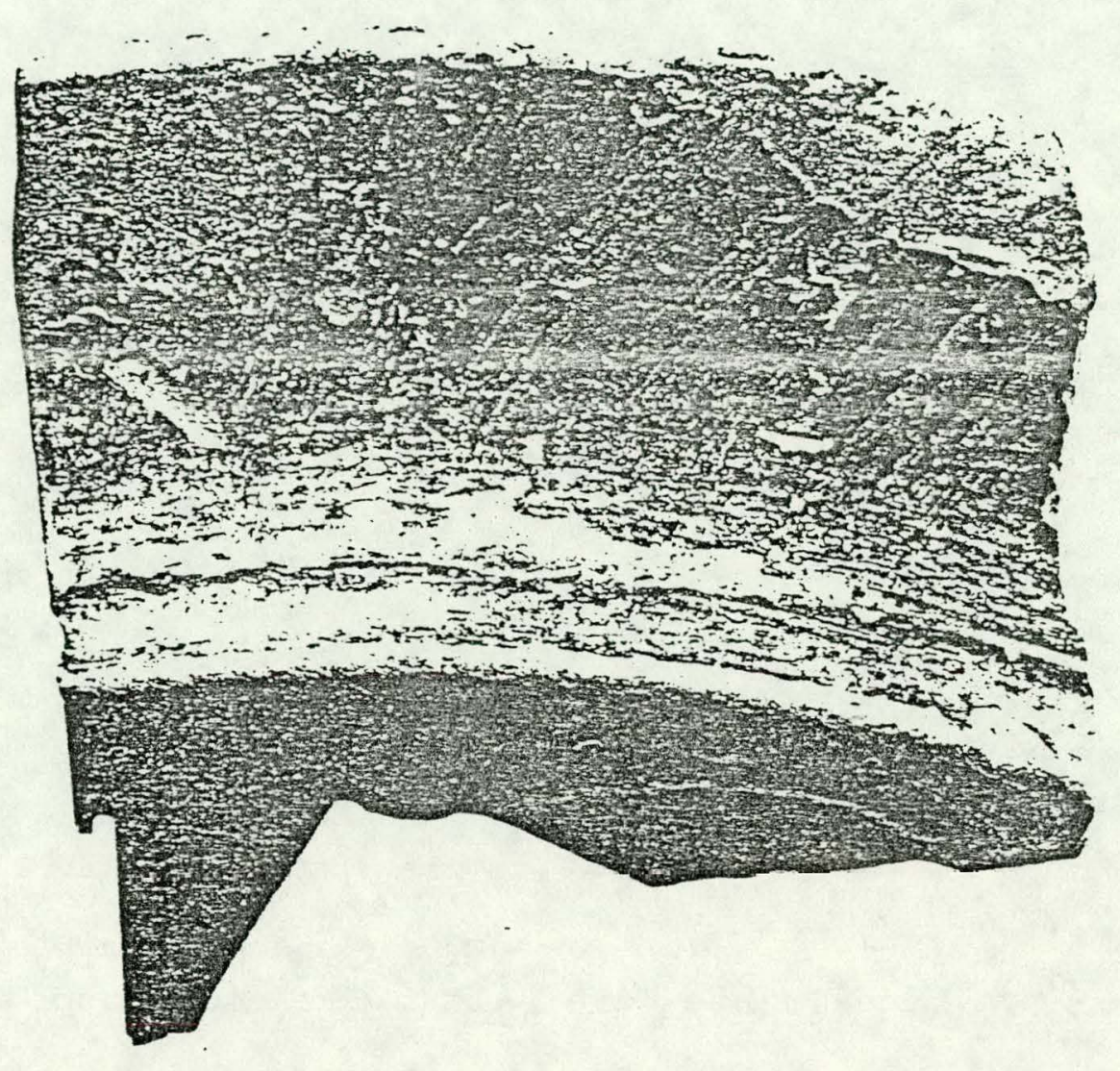

Figure 37. Early Fine Orange Ware. Calatrava, Specimen \# 229, unnamed Classic style polychrome, Naab Ceramic Complex, CPCRU 2. 
F:31

$A-2 \# 1$

$7 S / 000$

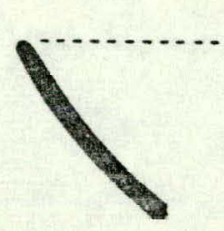

a
$5 \% 3$
$T-1173$
$T 49$

TS 1419

Figure 38. Fine Orange Ware, Altar Ceramic Group. a. Arenitas, Specimen \# 231; b. Trinidad, Specimen \# 273. a, b. Altar Orange Type, Jonuta horizon, CPCRU 2. One-third scale. 


$$
\begin{aligned}
& F=8 \\
& c-0 \# 8 \\
& \text { Ts. } 995
\end{aligned}
$$

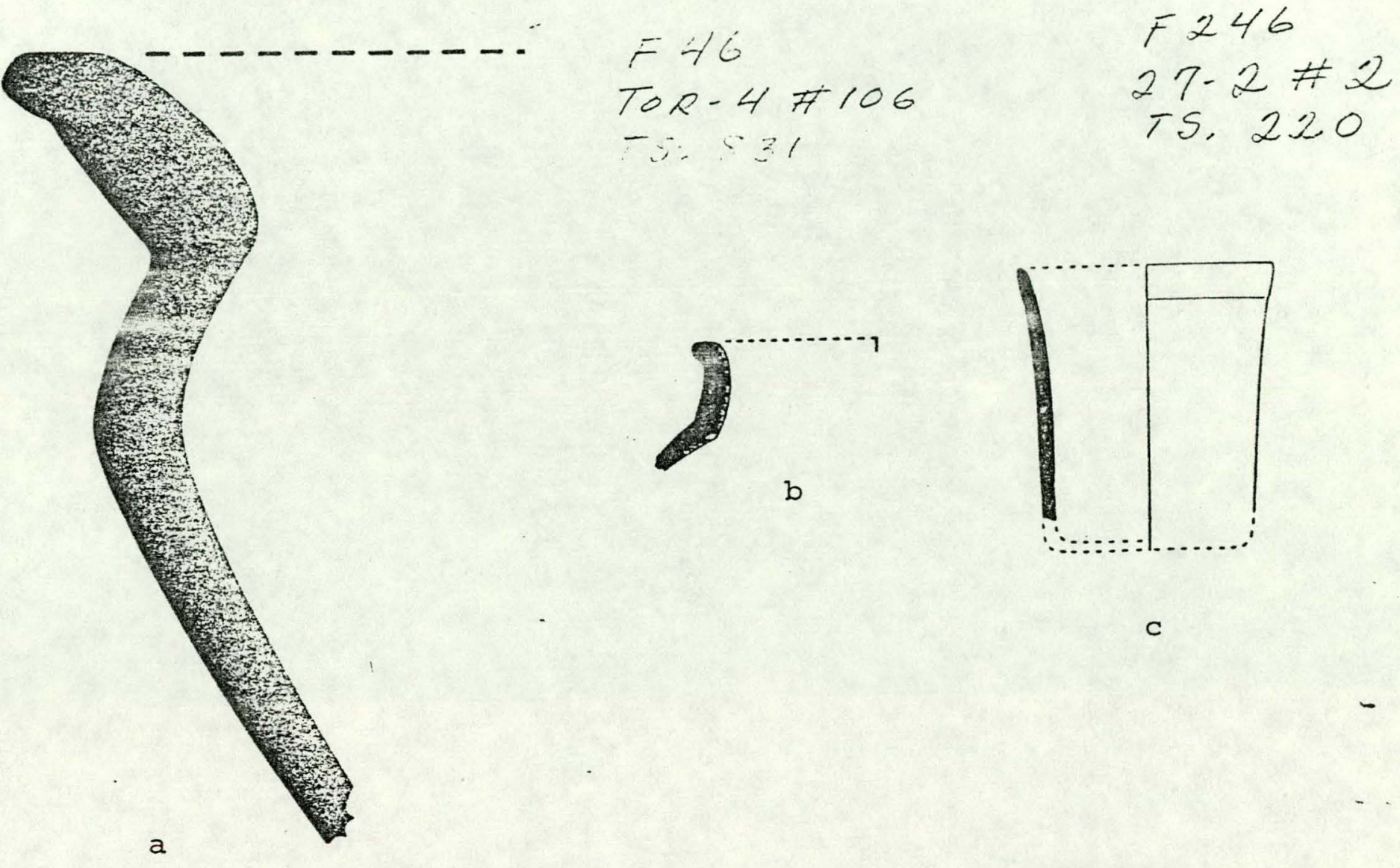

Figure 37. Fine Orange Ware, Altar Ceramic Group. a. Calatrava, Specimen \# 228, Jonuta horizon; b. Tortuguero, Specimen \# 46; c. Palenque, Specimen \# 246, Balunte Ceramic complex. a-c. Altar orange Type, CPCRU 5. One-third scale. 


\begin{tabular}{l}
$F 317$ \\
\hline$T S .16 \% 9$
\end{tabular}

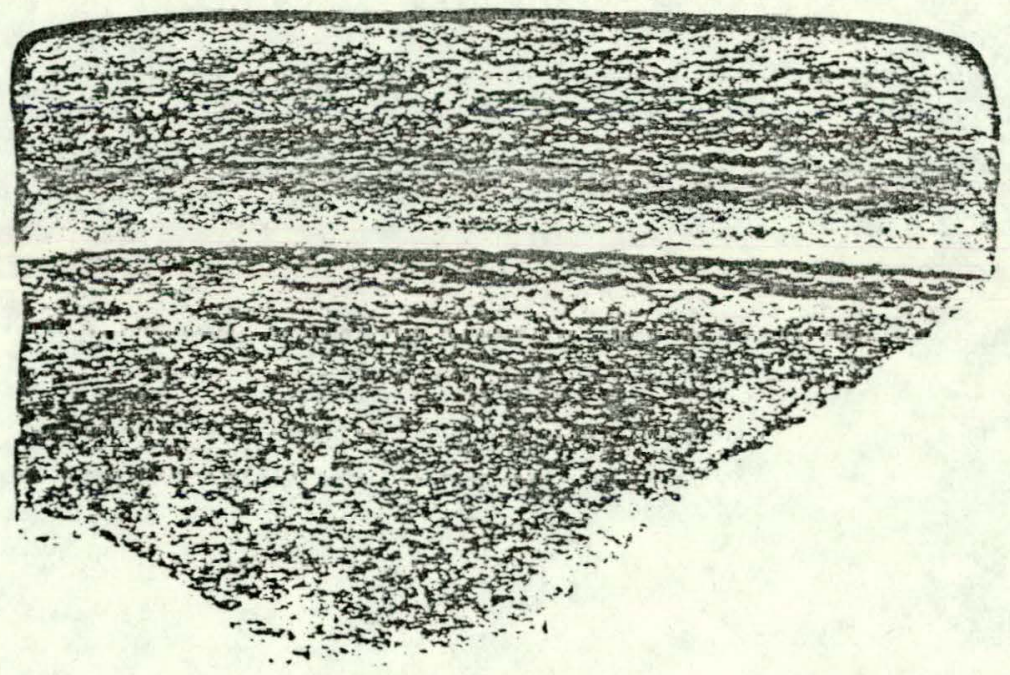

Figure 40. Fine Orange Ware, Altar ceramic Group. Piedras Negras, Specimen \# 317, Altar Orange Type, Post-Tamay horizon, CPCRU 1. 


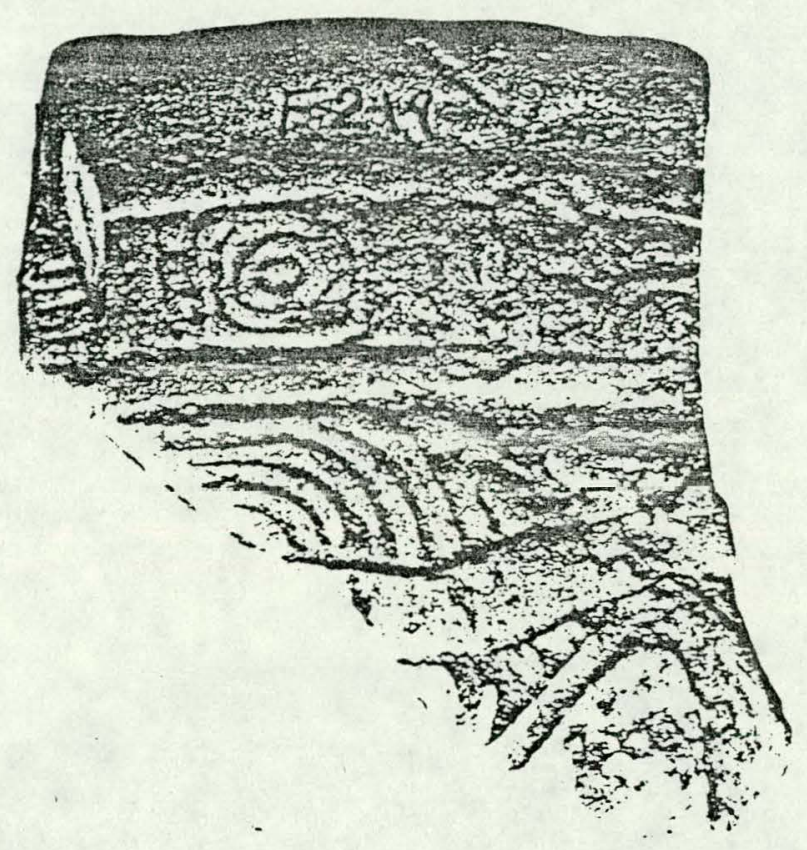

Figure 4 . Fine Orange Ware, Altar Ceramic Group.

Piedras Negras, Specimen \# 219, Pabellon Modeled-carved Type, Post-Tamay horizon, CPCRU 3. 


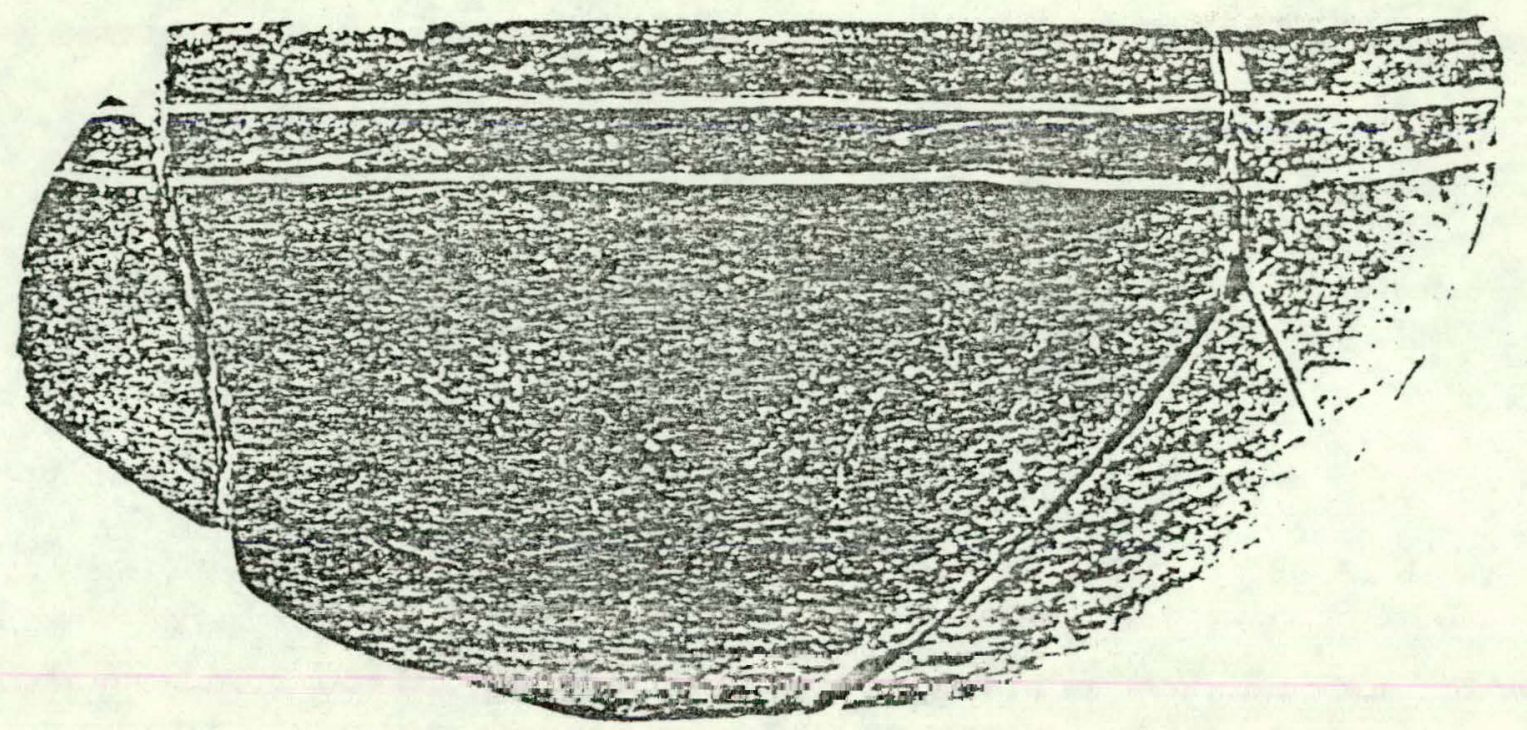

a

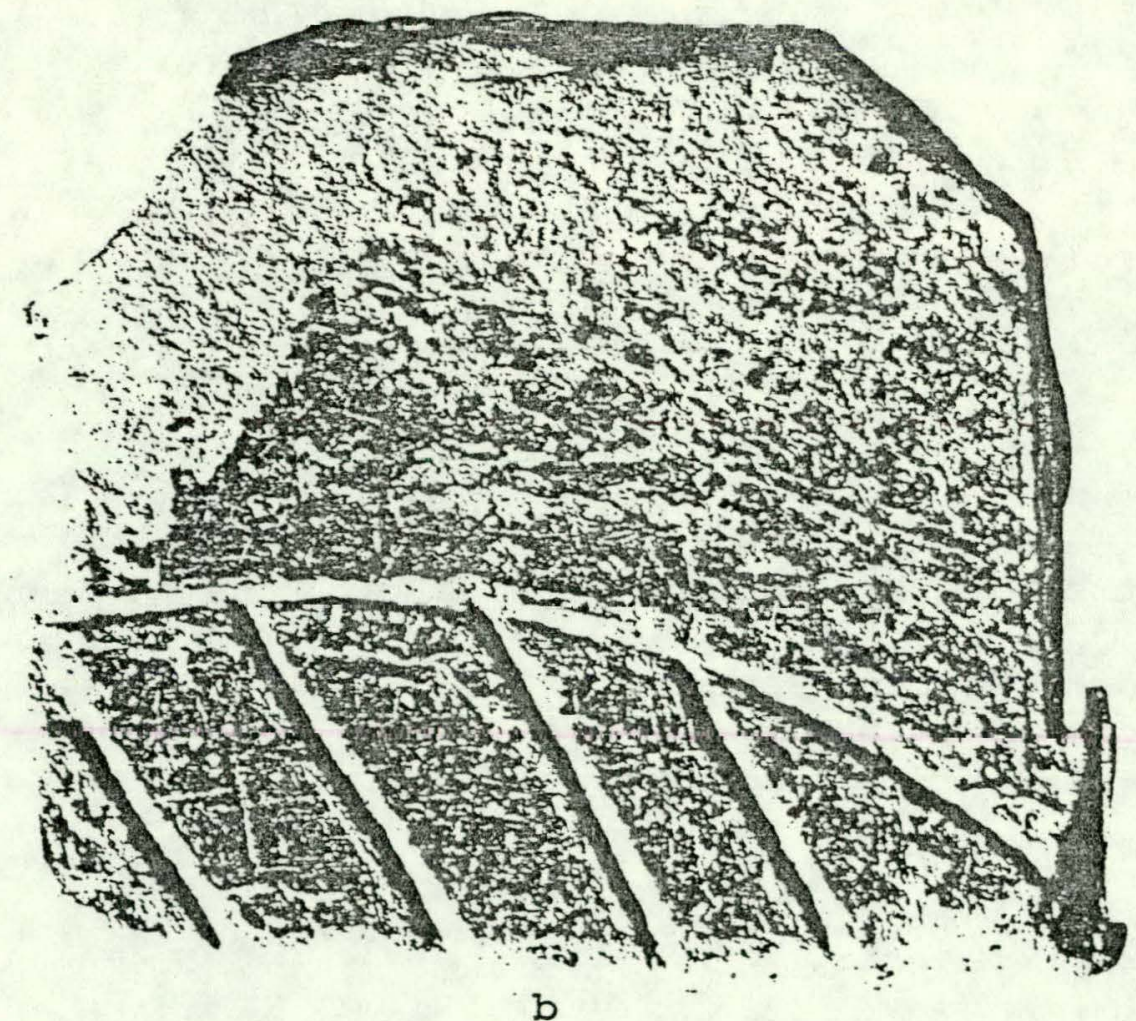

Figure 42. Fine Orange Ware, Altar ceramic Group. a. Calatrava, Specimen \#226, Tumba Black-on-orange Type, Jonuta horizon; b. Palenque, Specimen \# 66, Trapiche Incised Type, Balunte ceramic Complex. a, b. CPCRU 5. 

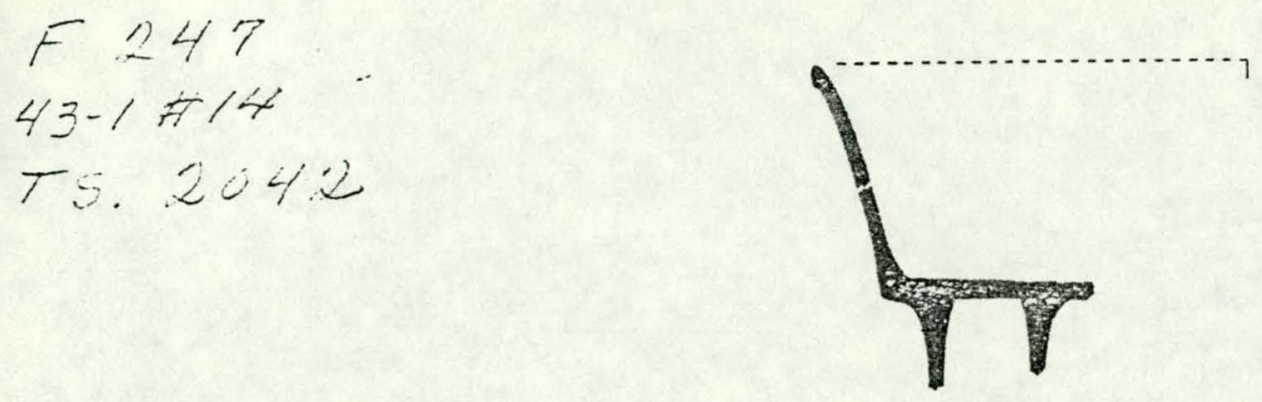

Figure 43. Fine Gray Ware, Tres Naciones Ceramic Group. Palenque, Specimen \# 247, Tres Naciones Gray Type, Balunte Ceramic Complex, .CPCRU 5. One-third scale. 
$F 218$

$\angle-16-998$

TS. 989

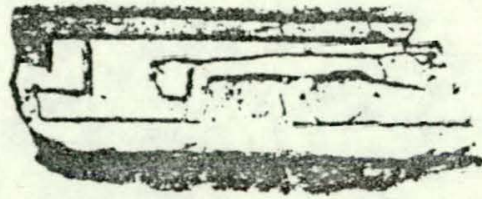

a

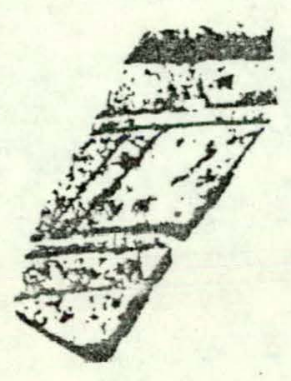

$\mathrm{b}$
Fæil

$\therefore \cdots$

$T 5,22$

Figure 4\%. Fine orange Ware, Balancan Ceramic Group. a, b. Piedras Negras, Provincia Plano-relief Type, Posṫ-Tamay horizon, unplaced in CPCRUs. a. Specimen \#218; b. Specimen \# 217. 


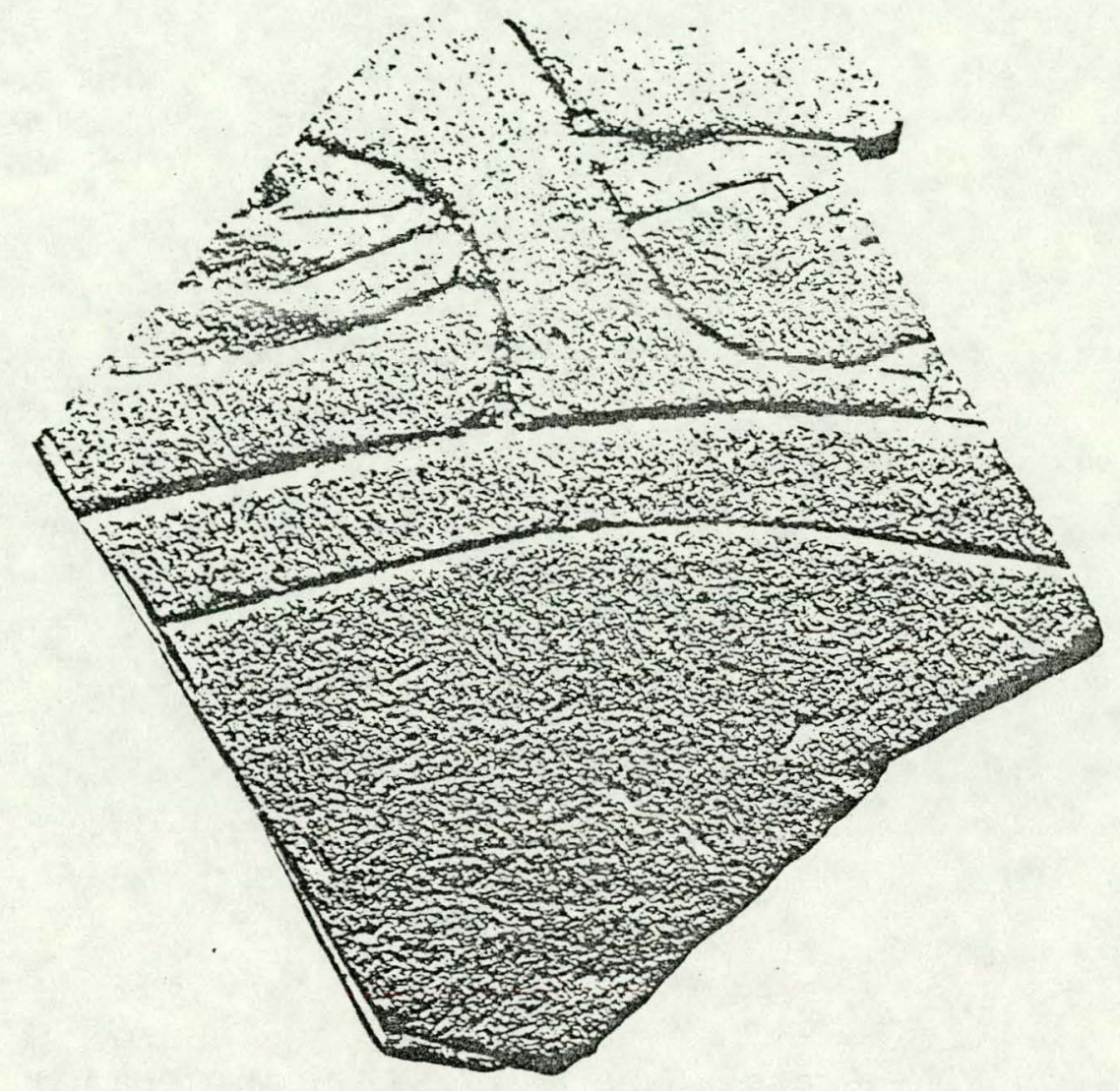

Figure 45. Fine orange Ware, Balancan Ceramic Group. Calatrava, Specimen \# 10, Provincia Plano-relief Type, Jonuta horizon, CPCRU 5. 


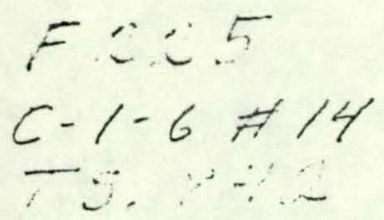

$F$

TOK $-2 \# 15$

TS. $\because 33$

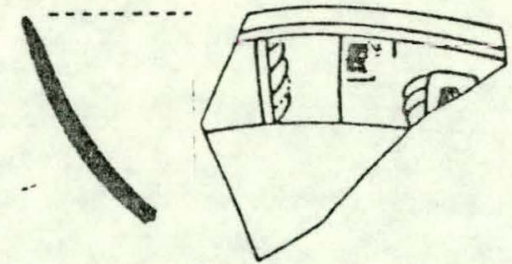

a
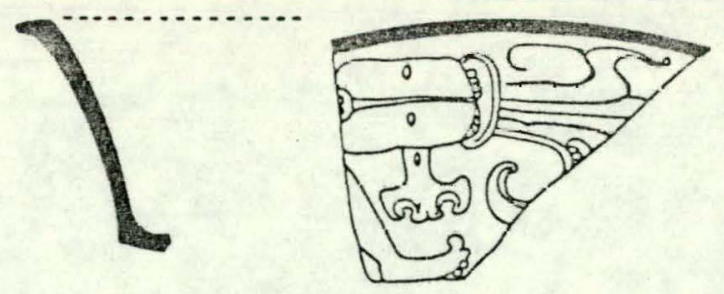

b

Figure 46. Fine orange Ware (a), Balancan Ceramic Group. a. Calatrava, Specimen \# 225, Provincia Plano-relief Type, Jonuta horizon, CPCRU 5; b. Tortuguero, Specimen \# 47, Provincia Plano-relief Type, Tortuguero compositional group. One-third scale. 


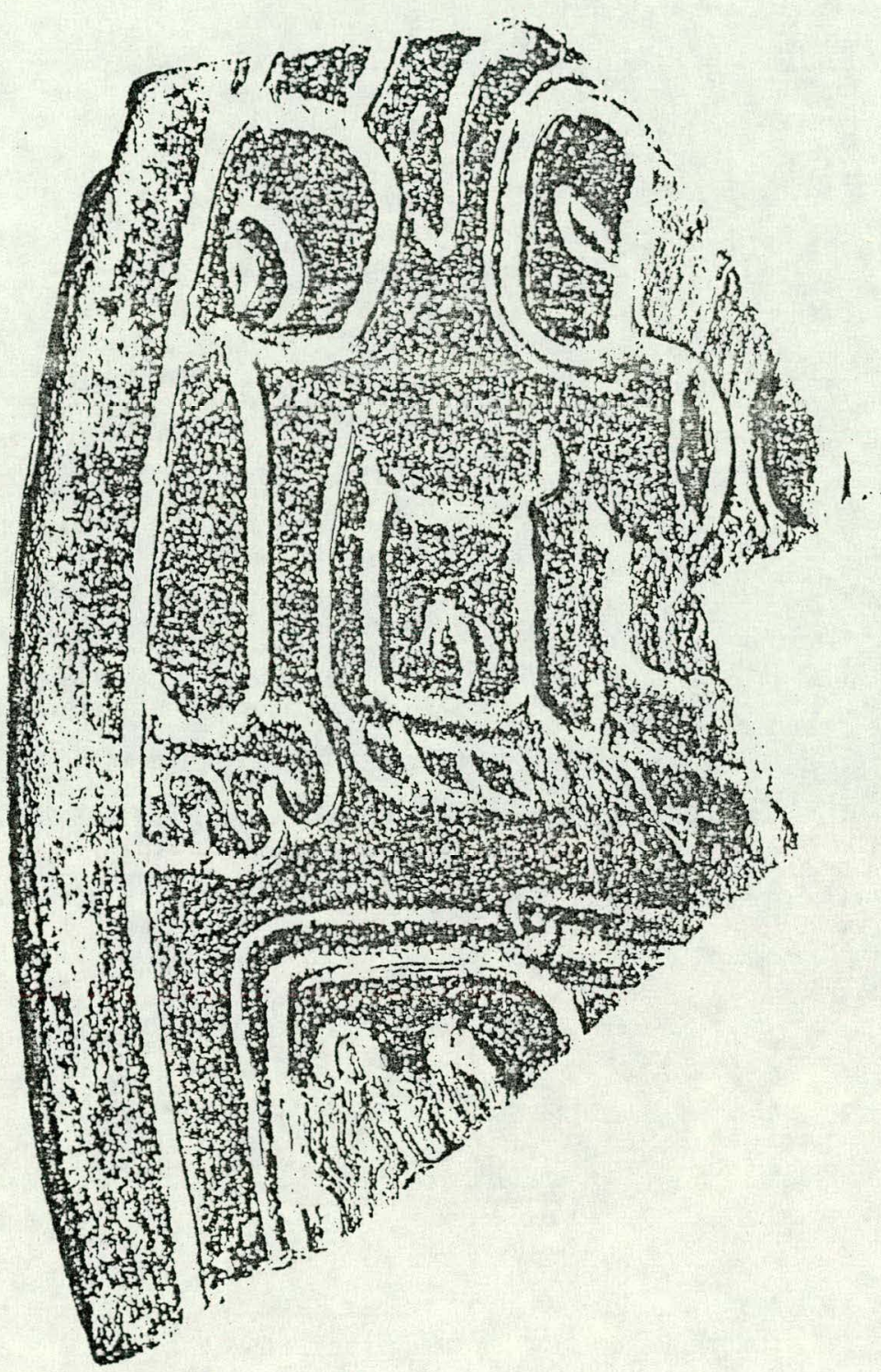

Figure 47. Fine orange Ware, Balancan Ceramic Group. Palenque, Specimen \# 57, Provincia Plano-relief Type, Balunte Ceramic Complex, CPCRU 1. 


\section{$F / 237$ \\ TS. 655}

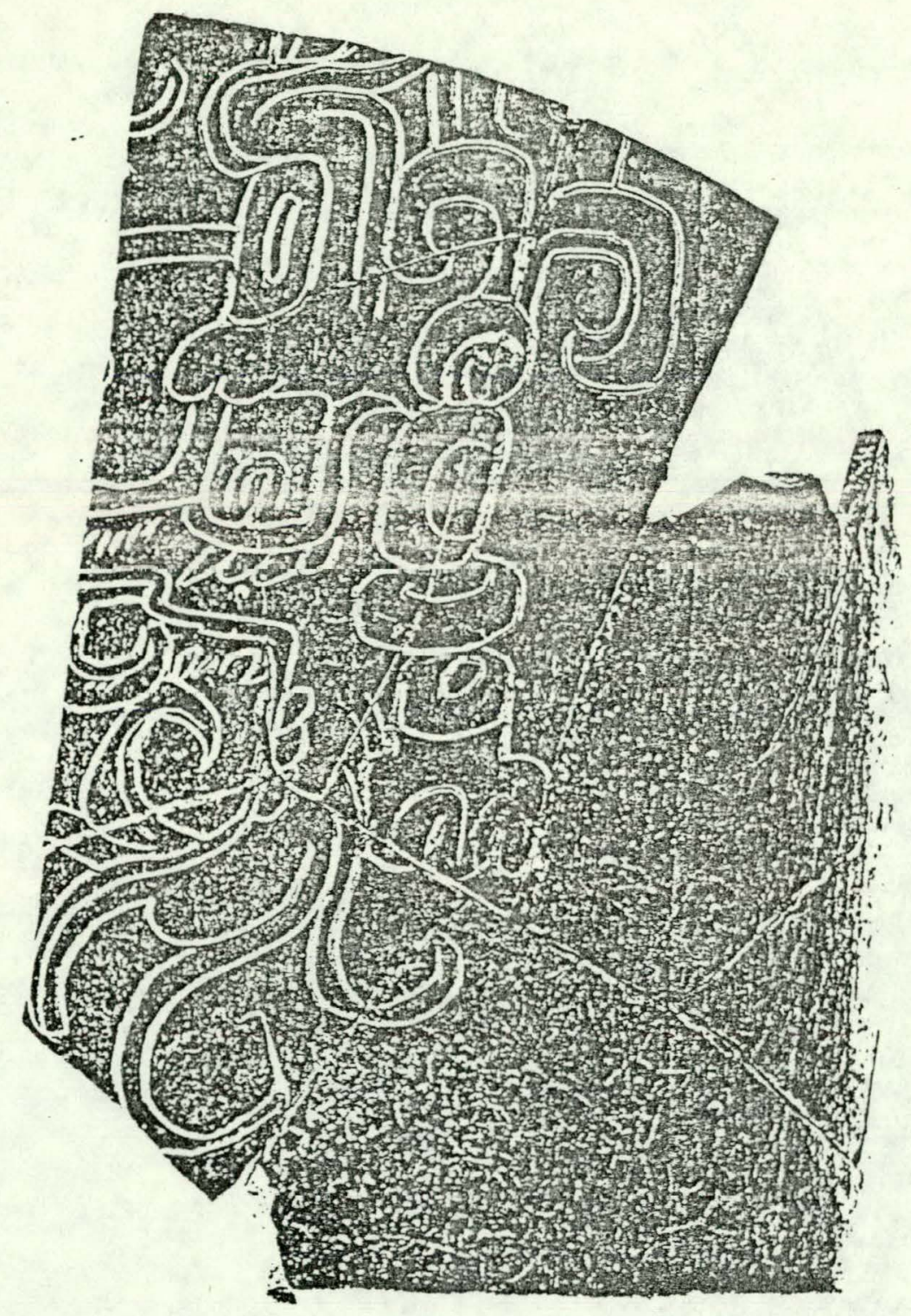

Figure 48. Fine orange Ware, unnamed composite type. Campeche (?), Specimen \# 1239. Black-on-orange (compare Tumba Type); incised design compares closely to Figure 19 (Provincia Plano-relief Type, Palenque), which also is in CPCRU 1. 

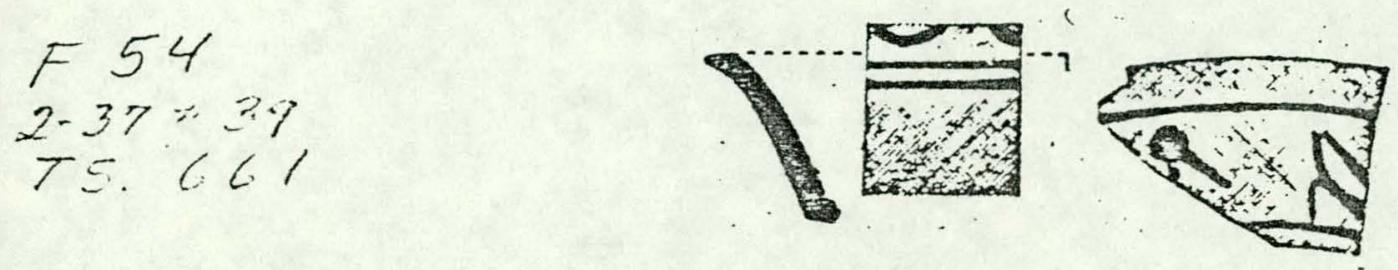

a

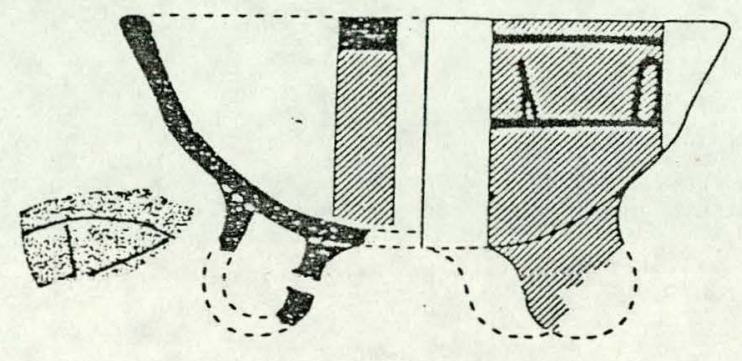

b

Figure 49. Fine Orange Ware, Silho Ceramic Group.

a, b. Palenque, Yalton Black-on-orange Type,

Terminal Classic to Early Postclassic, CPCRU 1.

a. Specimen \# 54; b. Specimen \# 81. One-third scale. 


$$
\begin{aligned}
& \text { F.211 } \\
& T=10 \# 348 \\
& T S .666
\end{aligned}
$$

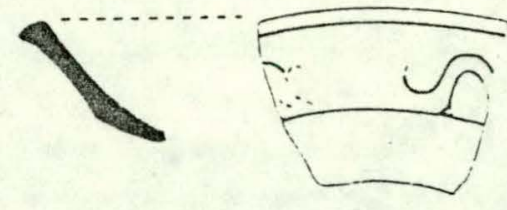

a
$F \% \%$

$T-11$ 1 346

75.272
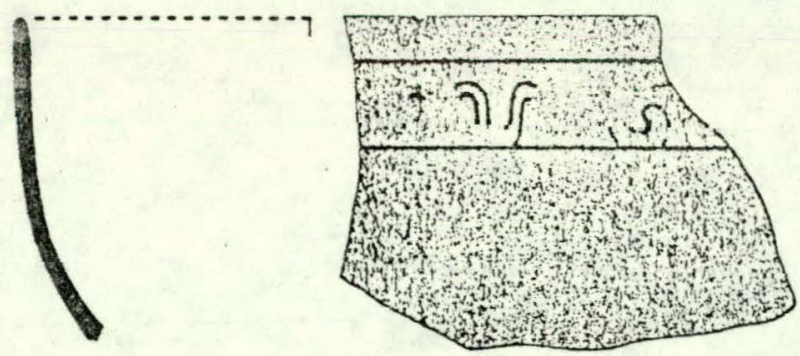

$\mathrm{b}$

Figure 50. Fine Orange Ware, Silho Ceramic Group.

a, b. Trinidad, Pocboc Gouged-incised Type, Terminal

Classic to Early Postclassic. a. Specimen 271,

unplaced in CPCRUs; b. Specimen 272, CPCRU 2.

One-third scale. 


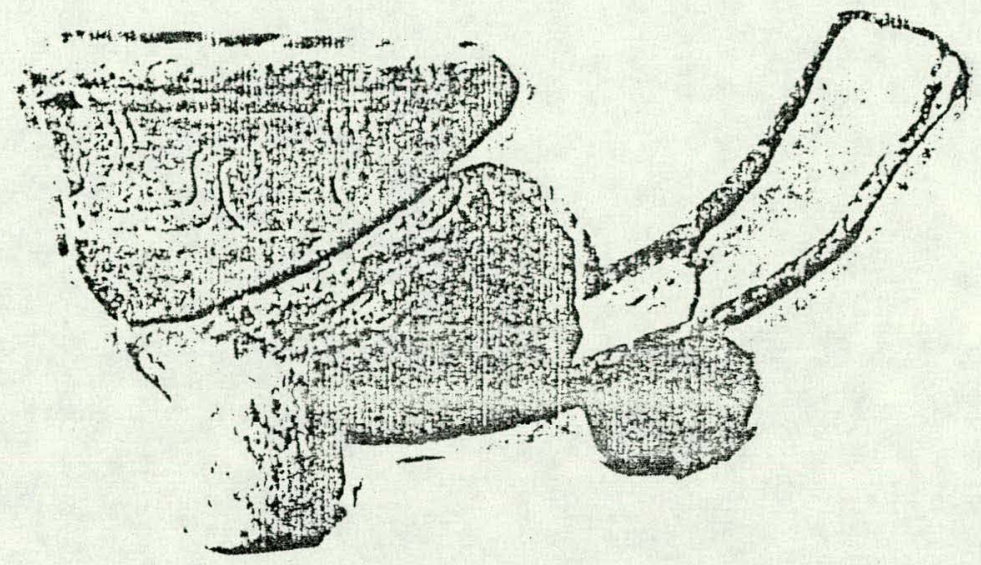

Figure 51. Fine orange Ware, Silho Ceramic Group. Bajio, Specimen \#1231, Pocboc Gouged-incised Type, Terminal Classic to Early Postclassic, unplaced in CPCRUs. 


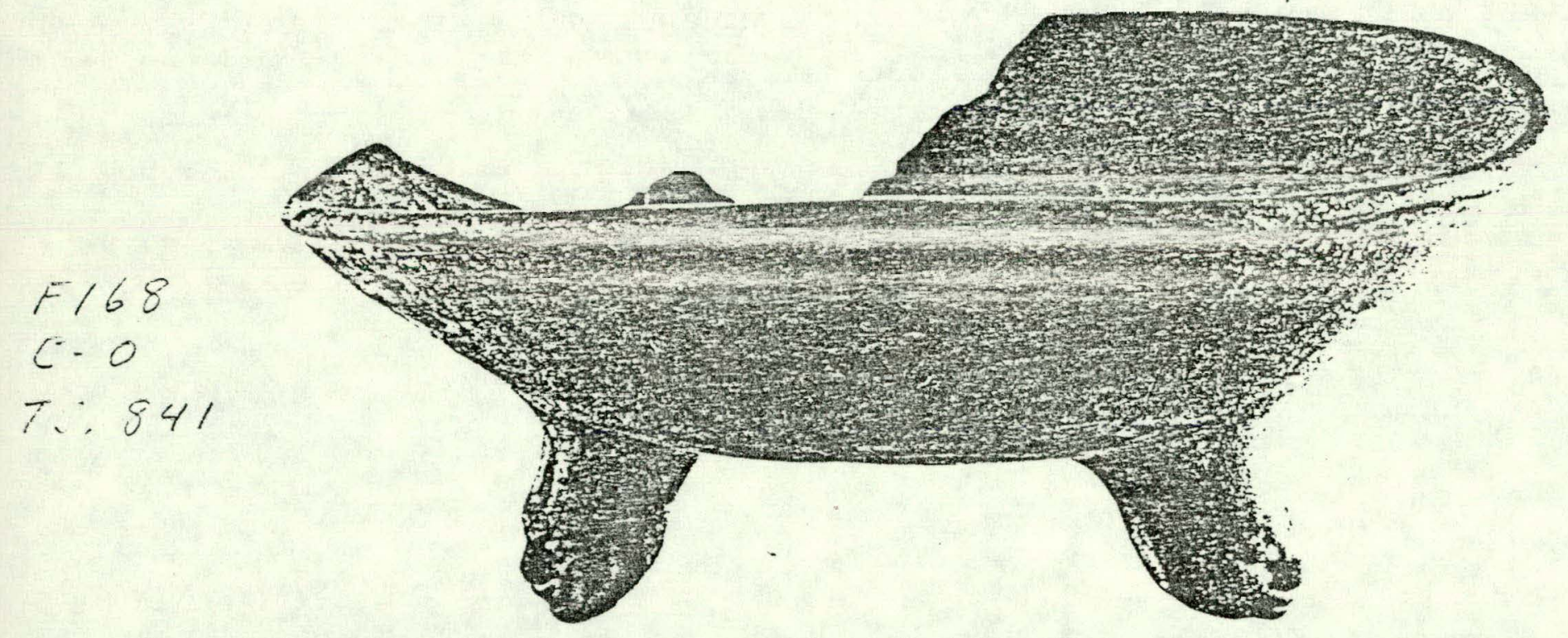

Figure 52, Fine orange Ware, Matillas Ceramic Group. Calatrava, Specimen \# 168, Matillas orange Type, Late Postclassic, CPCRU 5. 
F 880

$5 J R-2 \# 1$

$T:=008$

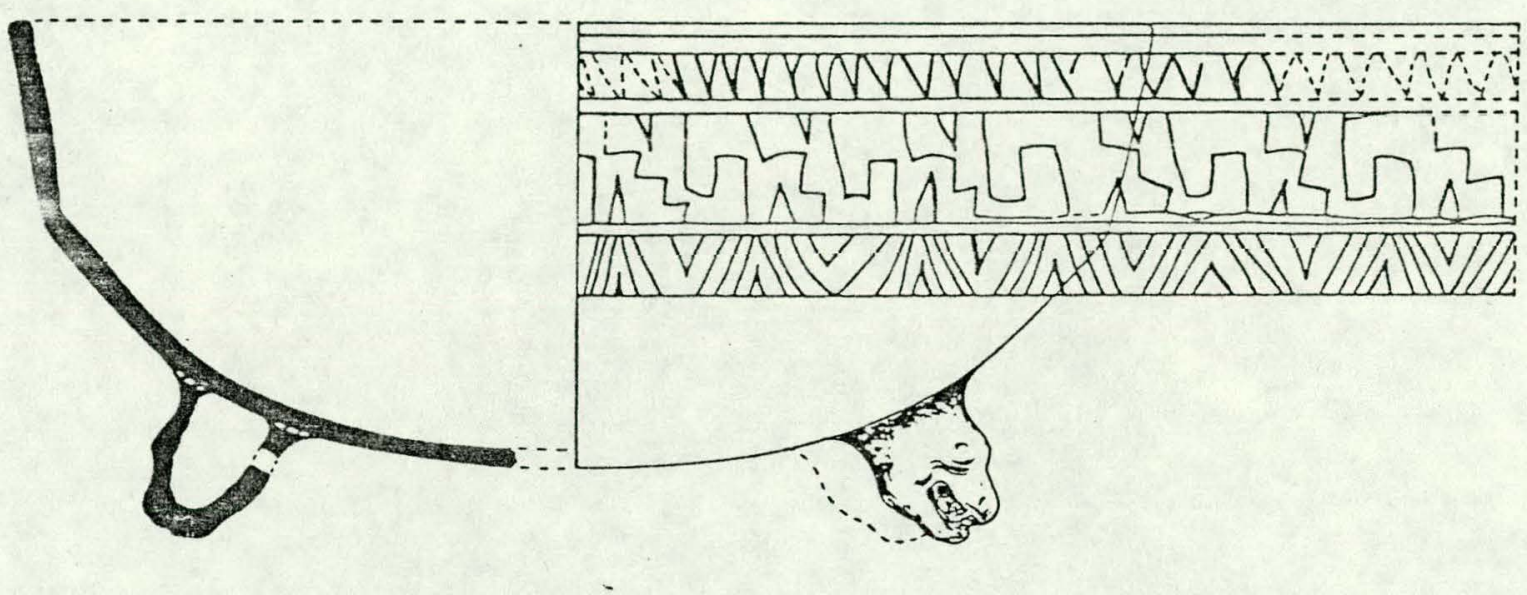

Figure 53. Fine Orange Ware, Matillas Ceramic Group. San Jose del Rio, Specimen \# 880, Villahermosa Incised Type, Late Postclassic, unplaced in CPCRUs. One-third scale. 
$F 270$

$c-0$

TS, 1054

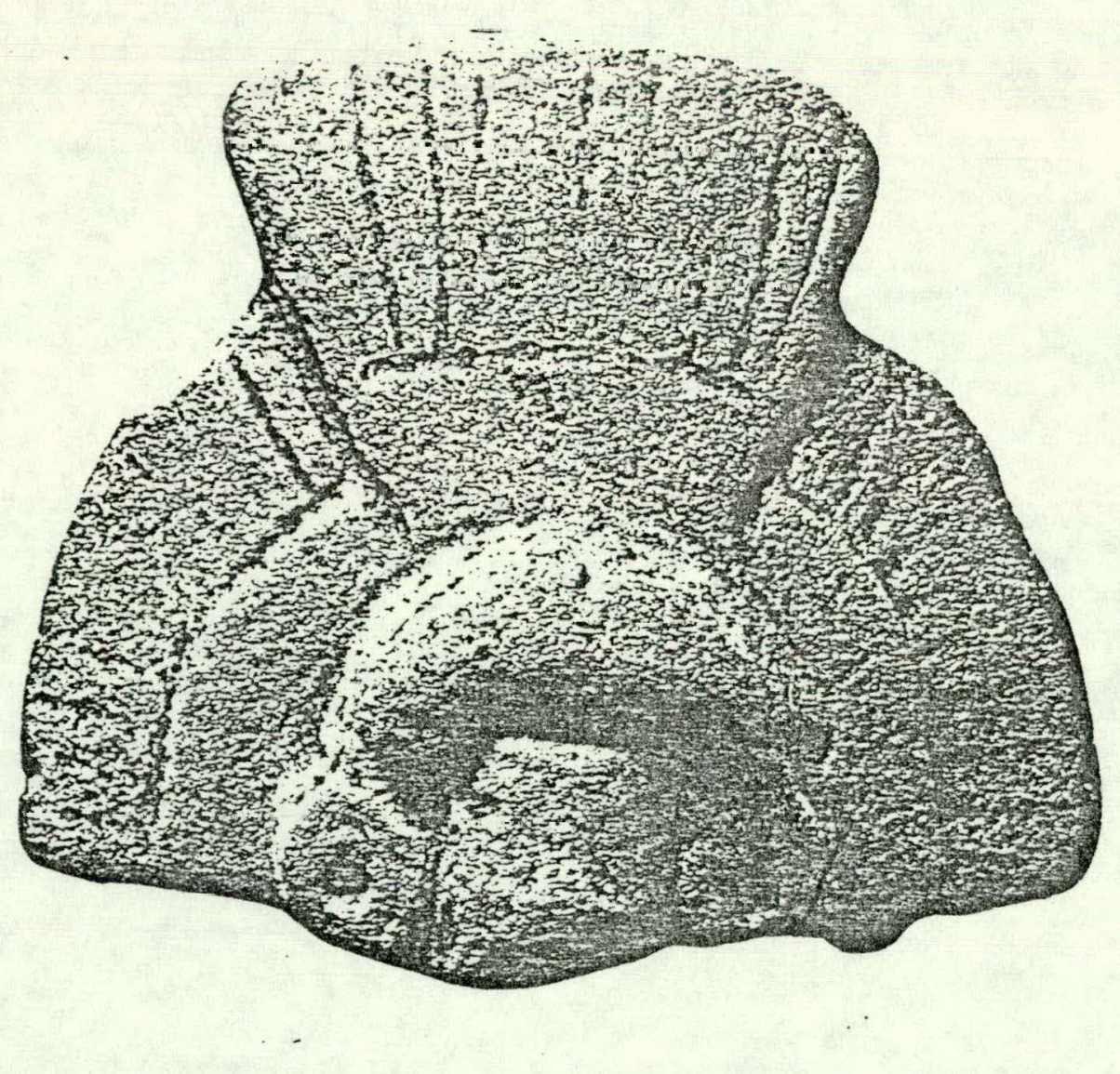

Figure 54. Fine Orange Ware figurine. Calatrava, Specimen \# 270, Jonuta horizon, CPCRU 5. 
CHEMICAL PASTE COMPOSITIONAL REFERENCE UNIT I

\begin{tabular}{|c|c|c|c|c|c|c|c|c|c|c|c|c|c|c|c|c|c|c|c|c|}
\hline SAMPLE & $\begin{array}{l}\text { NAZO } \\
\text { PCT }\end{array}$ & $\begin{array}{l}{ }_{\text {P }} 20 \\
\text { P Y }\end{array}$ & $\begin{array}{l}R A 20 \\
P P A\end{array}$ & $\underset{\text { PPM }}{\mathrm{CS} 20}$ & $\begin{array}{l}P_{A A O} \\
P P_{M}\end{array}$ & $\underset{\substack{\mathrm{SC2} 203 \\
\mathrm{PPM}}}{ }$ & $\underset{D P M}{\operatorname{LA}_{P D} 203}$ & 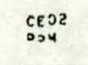 & 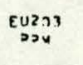 & $\underset{\mathcal{P}_{P M}}{\operatorname{Lu} 203}$ & $\underset{P P N^{M}}{\text { MF } 02}$ & $\underset{\substack{r+102 \\
\rho \rho x}}{202}$ & $\underset{P P M}{\mathrm{YAZOS}}$ & $\underset{\substack{C R 203 \\
P P M}}{C R M}$ & 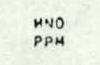 & $\begin{array}{l}\mathrm{FE}_{\mathrm{PCT}} \\
\mathrm{PCT}\end{array}$ & $\begin{array}{c}c 00 \\
P P_{M}\end{array}$ & $\underset{P P M}{S 3203}$ & $\begin{array}{l}\mathrm{CAO} \\
\mathrm{PCP}\end{array}$ & $\begin{array}{l}1102 \\
0_{C T T}\end{array}$ \\
\hline $\begin{array}{r}1230 \\
54\end{array}$ & $\begin{array}{l}.9355 \\
: 800\end{array}$ & $\begin{array}{l}1.930 \\
1.590\end{array}$ & $\begin{array}{l}A 2.100 \\
T A, 000\end{array}$ & $\begin{array}{r}3.210 \\
. \\
300\end{array}$ & $553 . n 00$ & 25.400 & 36.500 & 90.600 & 1.700 & .636 & 7.360 & 11.800 & 2.240 & 767.000 & 659.0000 & 5.520 & $37 .>2 n 0$ & & $\because 980$ & .902 \\
\hline 57 & :ae & 1.630 & 110.000 & $\because 900$ & $\begin{array}{r}68 . n 00 \\
0\end{array}$ & $\begin{aligned} 26.0000 \\
26.000\end{aligned}$ & & $\begin{array}{l}85.000 \\
79.000\end{array}$ & $\begin{array}{l}1.678 \\
1: 456\end{array}$ & $\begin{array}{l}4990 \\
: 690\end{array}$ & $\begin{array}{l}6.150 \\
7.090\end{array}$ & $\begin{array}{l}\begin{array}{l}11.100 \\
10.300\end{array} \\
1030\end{array}$ & $\begin{array}{l}1.380 \\
1.320\end{array}$ & $\begin{array}{l}800.000 \\
589.000\end{array}$ & $\begin{array}{l}607.0000 \\
\text { 336.000 }\end{array}$ & $\begin{array}{l}5.020 \\
5.010\end{array}$ & $\begin{array}{l}37 \\
29\end{array}$ & & 5.230 & 10 \\
\hline , & $\begin{array}{l}1.100 \\
9973\end{array}$ & $\begin{array}{l}2.000 \\
1,480\end{array}$ & 100.000 & 4.500 & $540 \cdot$ nno & 24. AOO & 4.000 & 110.000 & 1.936 & & 8.210 & 11.100 & 1.460 & 790.000 & 752,000 & 6.410 & 33.500 & .510 & 3.970 & $\therefore \rightarrow 0$ \\
\hline 1239 & 1.430 & 2.290 & 93.700 & $\begin{array}{l}3.910 \\
3.590\end{array}$ & 562.000 & $\begin{array}{l}29.100 \\
25,000\end{array}$ & $\because 0.900$ & 106.000 & $\begin{array}{l}1.796 \\
1.698\end{array}$ & .599 & 5.7 & $12.40 n$ & 1.140 & 546.000 & 1070.000 & 7.130 & 36.400 & -154 & 0.700 & . Aso \\
\hline 1236 & 1.030 & 2.350 & 96.000 & $\because .280$ & 576. & & $35 ; 000$ & $80^{\circ}$ & $\begin{array}{l}1.946 \\
1.990\end{array}$ & $\begin{array}{l}-541 \\
k \geq 9\end{array}$ & & $\begin{array}{l}10.300 \\
12.000\end{array}$ & 2.110 & 555.000 & $\begin{array}{l}821.0000 \\
1000\end{array}$ & 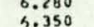 & $\begin{array}{l}31.000 \\
33,000\end{array}$ & .902 & $\begin{array}{l}7.020 \\
0.090\end{array}$ & .753 \\
\hline 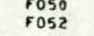 & 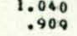 & $\begin{array}{l}1.770 \\
1.900\end{array}$ & $\begin{array}{l}121.093 \\
101.000\end{array}$ & $3: 800$ & $\begin{array}{l}518.000 \\
516: 000\end{array}$ & $\begin{array}{l}25.700 \\
23.700\end{array}$ & $\because 200$ & 87.500 & $10>00$ & 8763 & 6.860 & 11.300 & 1.230 & 550.000 & 716.000 & $\begin{array}{l}6.480 \\
6.58100\end{array}$ & 36.109 & 1.570 & $\begin{array}{l}8.410 \\
9.410\end{array}$ & 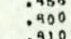 \\
\hline $\begin{array}{l}\text { MEAN } \\
\text { STO DEV }\end{array}$ & $\begin{array}{l}.987 \\
18 .\end{array}$ & $\begin{array}{l}1.454 \\
251\end{array}$ & 95.690 & 4.003 & 525.5 & 25.217 & 39.117 & 89.1 & $1.6>8$ & . 5968 & 6.679 & 11.279 & 1.506 & 646.431 & 753.736 & $6.3 \mathrm{AB}$ & 33.946 & & 6.139 & 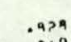 \\
\hline (a) & .063 & 12.837 & 14.3 & 5.040 & $\begin{array}{l}5.0740 \\
8.749\end{array}$ & $\begin{array}{l}1.259 \\
4.991\end{array}$ & $\begin{array}{r}5.5399 \\
16.531\end{array}$ & $\begin{array}{l}11.969 \\
13.595\end{array}$ & $\begin{array}{l}9133 \\
9157\end{array}$ & $\begin{array}{r}104 \\
\therefore \quad 697\end{array}$ & 12.492 & $\begin{array}{r}159 \\
0.021\end{array}$ & $\begin{array}{r}30.688 \\
300\end{array}$ & $\begin{array}{c}117.845 \\
19.207\end{array}$ & $\begin{array}{r}205.050 \\
26.848\end{array}$ & $\begin{array}{r}.350 \\
5: 486\end{array}$ & $\begin{array}{l}2.599 \\
7.949\end{array}$ & $\begin{array}{r}9.504 \\
7.931\end{array}$ & $\begin{array}{l}601 \\
695 \\
0.54\end{array}$ & \\
\hline
\end{tabular}

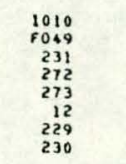

MEAN
STO OEV
(PGT)
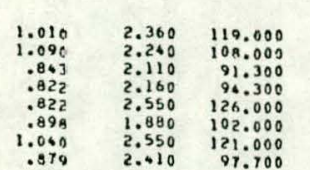

$\begin{array}{lll}.920 \quad 2.212 & 108.700\end{array}$
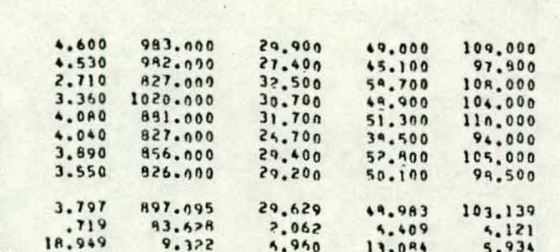

CHEMICAL

99.000
97.900
08.000
08.000
110.000
94.000
65.000
99.500
03.139
4.121
5.936
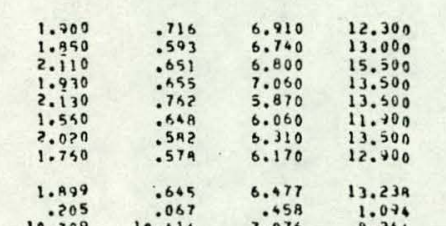

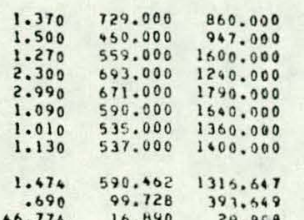

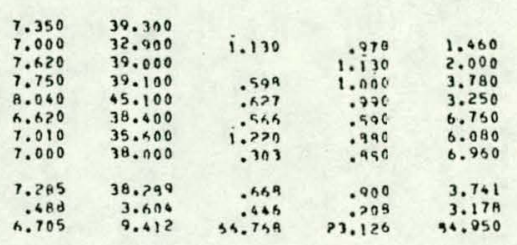

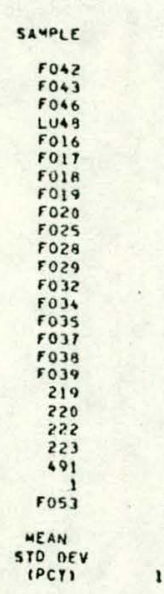

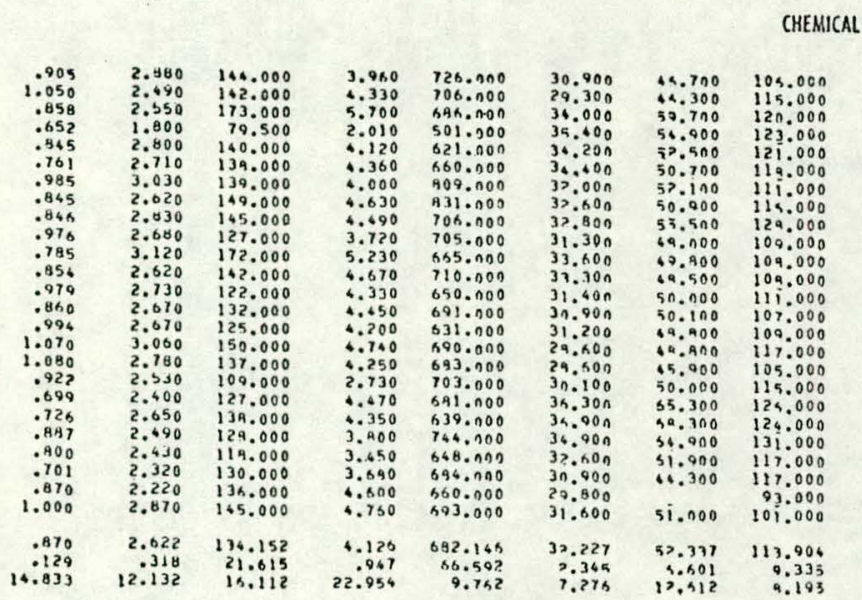

CHEMICAL PASTE COM.POSITIONAL REFERENCE UNIT 3
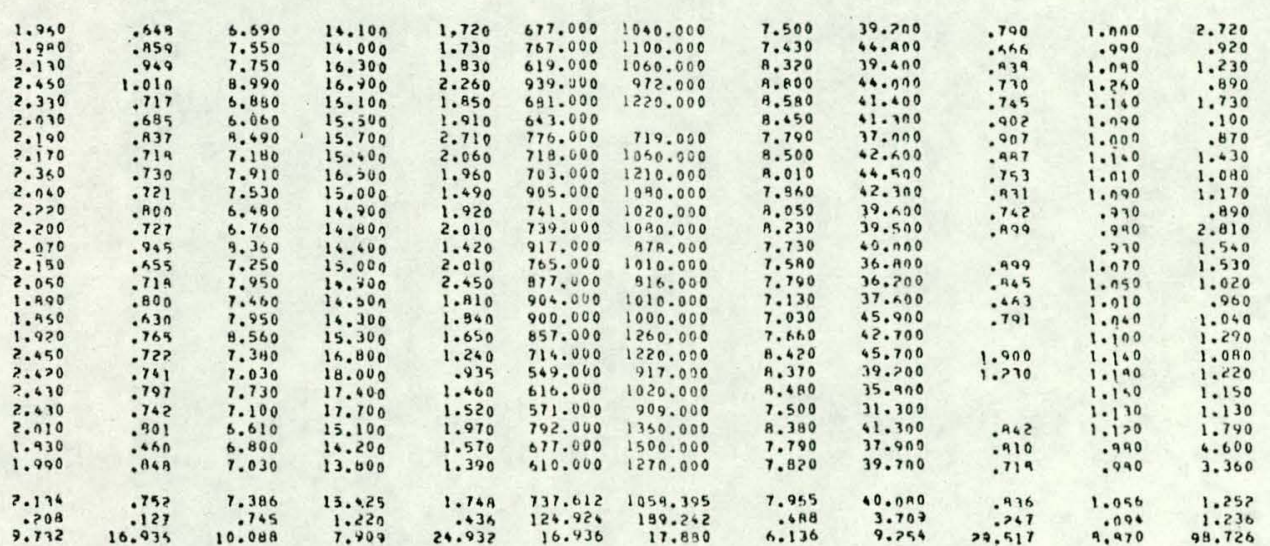

\footnotetext{
Table 1, a

BNL 4-811-80
} 
CHEMICAL PASTE COMPOSITIONAL REFERENCE UNIT 4

\begin{tabular}{|c|c|c|c|c|c|c|c|c|c|c|c|c|c|c|c|c|c|c|c|c|}
\hline MPLE & $\underset{\substack{\mathrm{NazO} \\
{ }_{\mathrm{PCT}}}}{0}$ & $\begin{array}{l}x_{200} \\
{ }_{\mathrm{P} C \mathrm{~T}}\end{array}$ & $\underset{P \text { PPM }}{\text { PB2 }}$ & $\underset{P O M}{C S 230}$ & 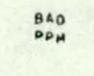 & 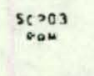 & 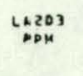 & 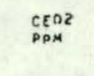 & $\begin{array}{c}E \cup 273 \\
\Delta>4\end{array}$ & $\begin{array}{l}\mathrm{LU} 20203 \\
004\end{array}$ & $\begin{array}{l}\mathrm{MFOL} \\
\mathrm{OOH}\end{array}$ & $\lim _{\substack{\ln 102 \\
\text { Oax }}}$ & 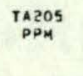 & $\underset{\mathrm{PPH}}{\mathrm{CH} 203}$ & 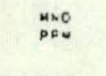 & 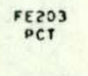 & ${ }_{\rho}^{c 00} \rho_{\mathcal{M}}^{c 0}$ & $\underset{P P M}{S B 223}$ & 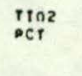 & $\begin{array}{l}\text { CAO } \\
\text { PCT }\end{array}$ \\
\hline $502 n$ & 1.090 & 2.470 & 116.000 & 4.900 & $\$ 51.100$ & $29 .=00$ & 50.300 & 106.000 & 2.270 & .679 & 8.100 & $16.10 \mathrm{~s}$ & 1.640 & 508.000 & 1150.000 & 7.560 & 37.400 & 1.050 & 1.000 & $\begin{array}{r}1,400 \\
1,340\end{array}$ \\
\hline 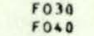 & $\begin{array}{l}1.220 \\
1.260\end{array}$ & $\begin{array}{l}2.000 \\
2.500\end{array}$ & $\begin{array}{l}151.000 \\
129.000\end{array}$ & $\begin{array}{r}5.580 \\
5.000\end{array}$ & $7+8.000$ & 24.900 & $\begin{array}{r}4.200 \\
5\end{array}$ & 112.000 & 2., 0100 & 1.050 & $\begin{array}{r}9.510 \\
9520\end{array}$ & 15.103 & $\begin{array}{l}1.470 \\
1.940\end{array}$ & & $\begin{array}{l}2020 \\
1010\end{array}$ & $\begin{array}{r}7.550 \\
7.390\end{array}$ & $\begin{array}{l}+2.100 \\
38.200\end{array}$ & $\begin{array}{l}.804 \\
\therefore .190\end{array}$ & $\begin{array}{l}1.060 \\
.900\end{array}$ & $\begin{array}{l}1.340 \\
1.270\end{array}$ \\
\hline $\mathrm{Fo+1}$ & 1.170 & $\begin{array}{l}2.250 \\
2.830\end{array}$ & 140.000 & 5.640 & $\begin{array}{r}119.000 \\
\end{array}$ & $2 \because 400$ & 5.700 & 105.000 & $\begin{array}{l}0.0560 \\
1.930\end{array}$ & $\begin{array}{l}.641 \\
.939\end{array}$ & $\begin{array}{l}8.0260 \\
9.920\end{array}$ & 15,105 & 1.410 & 624000 & $\begin{array}{r}949.000 \\
\end{array}$ & 7.010 & $\$ 8.100$ & .002 & $: 9>0$ & \\
\hline $\begin{array}{l}\begin{array}{l}F 047 \\
6048\end{array} \\
\text { F }\end{array}$ & $\begin{array}{l}1.270 \\
1.520\end{array}$ & $\begin{array}{l}2.870 \\
2.050\end{array}$ & $\begin{array}{l}149.000 \\
144: 000\end{array}$ & $\begin{array}{l}0.570 \\
5.260\end{array}$ & $\begin{array}{l}798.0100 \\
751.000\end{array}$ & $\begin{array}{l}20.300 \\
20.000\end{array}$ & $\begin{array}{l}5.900 \\
0.900\end{array}$ & $\begin{array}{r}105.000 \\
979900\end{array}$ & $\begin{array}{l}1: 970 \\
1.4950\end{array}$ & $\begin{array}{r}739 \\
0649\end{array}$ & $\begin{array}{l}7.0200 \\
9.260\end{array}$ & $\begin{array}{l}15.50 \\
14.600\end{array}$ & $\begin{array}{l}1.320 \\
1.500\end{array}$ & $\begin{array}{l}463.000 \\
5 \$ 7.000\end{array}$ & $\begin{array}{l}1170.600 \\
1100.000\end{array}$ & $\begin{array}{l}7.070 \\
7.020\end{array}$ & $\begin{array}{l}37: 0000 \\
36: 000\end{array}$ & 1.967 & $\begin{array}{l}7900 \\
: 9.0\end{array}$ & \\
\hline 1179 & 1,160 & $\begin{array}{l}2.3740 \\
2.470\end{array}$ & 143.0000 & 5.880 & 554.000 & 24.200 & 3000 & 121.000 & 2.050 & $\therefore \geq ?$ & 8.520 & 15.103 & $1 x^{3}$ & $\begin{array}{r}476.000 \\
583\end{array}$ & 1190.000 & 7.130 & 38.500 & 150 & 1000 & \\
\hline${ }_{317}^{317}$ & & & $\begin{array}{l}104.000 \\
101,000\end{array}$ & & $\begin{array}{l}551.000 \\
537.000\end{array}$ & $\begin{array}{l}24.800 \\
24: 200\end{array}$ & $\begin{array}{l}5.900 \\
\square .900\end{array}$ & $\begin{array}{r}129.000 \\
1220000\end{array}$ & $\begin{array}{r}2.190 \\
1990\end{array}$ & 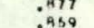 & $\begin{array}{r}10.100 \\
9.770\end{array}$ & $\begin{array}{l}15.00 \\
15: 109\end{array}$ & 1.520 & 025.000 & 1120.000 & $7.4 B 0^{\circ}$ & 38.400 & $\begin{array}{l}1.150 \\
.973\end{array}$ & .090 & \\
\hline $\begin{array}{l}1226 \\
1227\end{array}$ & $\begin{array}{r}.980 \\
1.960\end{array}$ & 2.900 & $\begin{array}{r}13.000 \\
30.000\end{array}$ & 5.880 & 150.000 & 30.300 & $\begin{aligned} 1000 \\
\therefore \quad 000\end{aligned}$ & 104.000 & $\therefore \because 990$ & 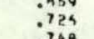 & 6.740 & 11.000 & $\begin{array}{l}1.720 \\
2.050\end{array}$ & $\begin{array}{l}5 \in 6.000 \\
053,000\end{array}$ & $\begin{array}{l}1280.000 \\
1970.000\end{array}$ & $\begin{array}{l}7.520 \\
7.350\end{array}$ & $\begin{array}{l}37.400 \\
\end{array}$ & & $\begin{array}{l}90,7 \\
: 997\end{array}$ & \\
\hline & 1.200 & 2.645 & 127.360 & 5.365 & $696.4>1$ & $\mathrm{ARQ}_{0}$ & nat & 100.544 & $2, a ?$ & . $7 A_{B}$ & 8.609 & $\mid t+, T_{1}$ & 1.605 & 562.564 & 1257.618 & $\begin{array}{l}1.384 \\
.250\end{array}$ & 39.149 & 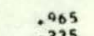 & $\begin{array}{l}-44 ? \\
-45 ?\end{array}$ & \\
\hline & $\begin{array}{l}.154 \\
831 \\
x_{1}\end{array}$ & 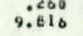 & 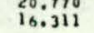 & .90 & $\begin{array}{l}9.626 \\
9.997\end{array}$ & & $\begin{array}{l}.201 \\
n 0 y\end{array}$ & $\begin{array}{l}7.587 \\
9.733\end{array}$ & , & .137 & $\begin{array}{r}12.100 \\
12.779\end{array}$ & $\begin{array}{l}.377 \\
3.629\end{array}$ & $\begin{array}{l}2519 \\
7709\end{array}$ & $\begin{array}{l}67.565 \\
12.010\end{array}$ & $\begin{array}{r}35.468 \\
27.910\end{array}$ & $\begin{array}{l}\mathbf{2} 250 \\
3.380\end{array}$ & $\begin{array}{l}3.446 \\
8.747\end{array}$ & $: 341$ & . 075 & \\
\hline
\end{tabular}

SAMPLE
FOA4
FO23
322
9
10
13
169
225
226
227
227
270
335
1228
2
3
4
5
6
7
242
66
246
247
46
1236

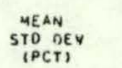

SAMPLE

SAMPLE

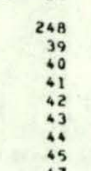
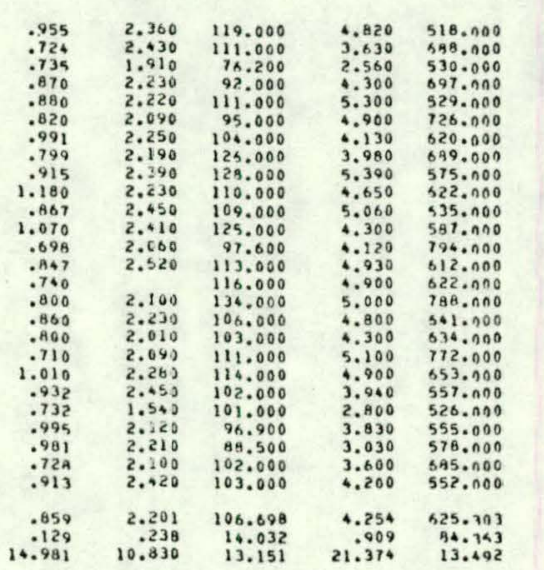

CHEMICAL PASTE COMPOSITIONAL REFERENCE UAIT S

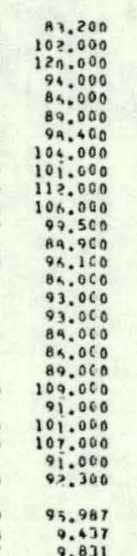
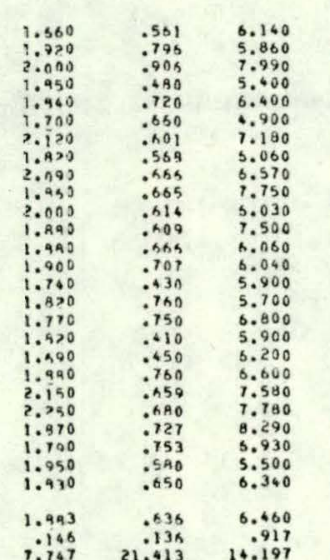

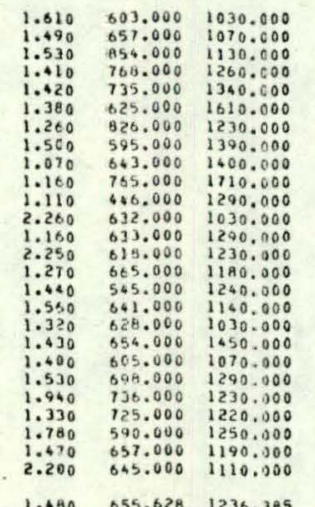

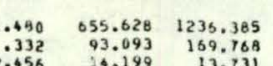

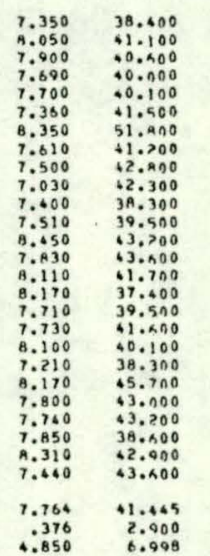

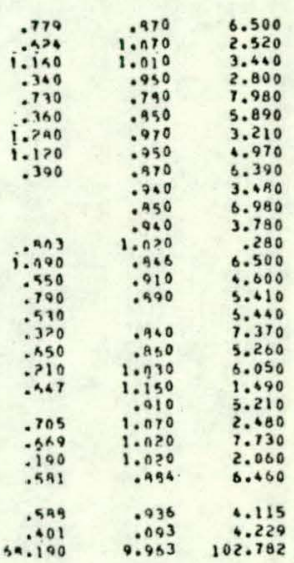

TORTUGUERO REFERENCE UNIT

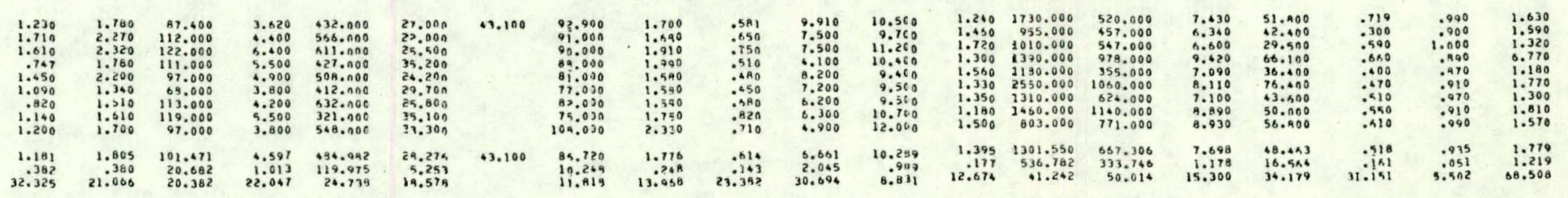

Table 1 b

BNL 4-810-80 
NON-GROUPED SPECIMENS

\begin{tabular}{|c|c|c|c|c|c|c|c|c|c|c|c|c|c|c|c|c|c|c|c|c|}
\hline SAMPLE & $\begin{array}{l}\text { NaZO } \\
\text { PCT }\end{array}$ & $\begin{array}{l}\mathrm{r}_{200} \\
\mathrm{PCr}\end{array}$ & $\begin{array}{l}{ }_{P P P}^{R B 20} \\
P P H\end{array}$ & $\underset{P P M}{\operatorname{cs} 20}$ & $\begin{array}{l}B A O \\
P P_{M}\end{array}$ & 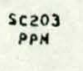 & $\underset{P P M}{L_{P 203}}$ & $\underset{P P M}{\underset{P}{C} \mathrm{CO} 2}$ & 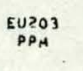 & $\underset{P P M}{L L_{P P} 03}$ & $\underset{P P M}{\mathrm{HFOO}}$ & $\underset{P P M}{Y H O Z}$ & $\begin{array}{c}\text { TAZOSS } \\
\text { PPPM }\end{array}$ & $\underset{\text { PPM }}{\mathrm{C} 203}$ & $\begin{array}{l}\text { MNO } \\
\text { PPO }\end{array}$ & $\underset{\mathrm{PCT}}{\mathrm{F}\{203}$ & $\begin{array}{l}\text { con } \\
\text { PP }\end{array}$ & $\mathrm{SP}_{\mathrm{PPA}} 203$ & ${ }_{\mathrm{PCT}}^{\mathrm{ryO}}$ & $\begin{array}{l}{ }^{A A} 0 \\
P C T\end{array}$ \\
\hline 1009 & 1.110 & 2.280 & 111.000 & 5.940 & $11+0.000$ & 34.200 & 11.000 & 113.000 & 1.796 & $.5 A 7$ & 4.890 & 11,800 & & 609.000 & 720.000 & & & & & \\
\hline 1012 & $\begin{array}{l}.632 \\
: 817\end{array}$ & $\begin{array}{l}2.640 \\
2.300\end{array}$ & & 7.020 & 1980.000 & 26.100 & & 72.800 & 1.596 & .590 & 5.910 & 8.900 & 1.250 & 95.100 & & 5.580 & 18.400 & $\therefore 510$ & & 5.230 \\
\hline $\begin{array}{l}1012 \\
1237\end{array}$ & $\begin{array}{l}817 \\
: 975\end{array}$ & $\begin{array}{l}2.300 \\
2.030\end{array}$ & $\begin{array}{r}114.000 \\
93.500\end{array}$ & $\begin{array}{l}4.290 \\
3.880\end{array}$ & $\begin{array}{l}1370.000 \\
16100\end{array}$ & $\begin{array}{l}33,+500 \\
27,000\end{array}$ & $\begin{array}{l}44.300 \\
30 ; 000\end{array}$ & 107.000 & 1.756 & $\begin{array}{r}.593 \\
580\end{array}$ & 5.720 & 12.000 & 1.490 & 770.000 & 1190.000 & 9.160 & $\$ 3.090$ & .515 & & 3.530 \\
\hline $123 \mathrm{~A}$ & $=\mathrm{A24}$ & 2.300 & $\begin{array}{l}93.500 \\
84.500\end{array}$ & $\begin{array}{l}3.880 \\
6.030\end{array}$ & $\begin{array}{l}2020.000 \\
20000\end{array}$ & $\begin{array}{l}77.000 \\
25.500\end{array}$ & $\begin{array}{l}37.200 \\
35,500\end{array}$ & $\begin{array}{l}A_{1} \cdot 500 \\
B_{0} \cdot 500\end{array}$ & $\begin{array}{l}1.536 \\
1.970\end{array}$ & $\begin{array}{r}5 \mathrm{Ag} 9 \\
5398\end{array}$ & $\begin{array}{l}5.600 \\
5,170\end{array}$ & $\begin{array}{l}10.300 \\
11100\end{array}$ & $\begin{array}{l}2.650 \\
1.630\end{array}$ & $\begin{array}{l}526.000 \\
1320000\end{array}$ & $\begin{array}{l}1000.000 \\
428,000\end{array}$ & $6 . \times 00$ & 34.000 & & 9.9? & $\begin{array}{l}4040 \\
1700\end{array}$ \\
\hline 969 & 2.180 & $\begin{array}{l}1.900 \\
3.590\end{array}$ & 84.200 & $\begin{aligned} 4000 \\
\therefore\end{aligned}$ & 1050.000 & 12.500 & $\begin{array}{ll}36 \\
26000\end{array}$ & 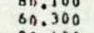 & $.71^{9}$ & $\begin{array}{l}538 \\
.415\end{array}$ & $\begin{array}{l}5.770 \\
6.640\end{array}$ & $\begin{array}{l}11.1 .100 \\
15.300\end{array}$ & $\begin{array}{l}1.630 \\
1.340\end{array}$ & $\begin{array}{r}132.000 \\
65.200\end{array}$ & $\begin{array}{l}\$ 28.000 \\
555.000\end{array}$ & $\begin{array}{l}6.000 \\
4.020\end{array}$ & $\begin{array}{l}16.400 \\
19.500\end{array}$ & $\begin{array}{l}.923 \\
1.500\end{array}$ & & 1.710 \\
\hline $\begin{array}{r}970 \\
F 045\end{array}$ & $\begin{array}{r}.339 \\
1: 375\end{array}$ & $\begin{array}{l}2.540 \\
2.290\end{array}$ & $\begin{array}{l}287.000 \\
119.000\end{array}$ & 26.000 & $\begin{array}{r}1060 \cdot 000 \\
551\end{array}$ & $\begin{array}{l}33.900 \\
4.200\end{array}$ & 37.300 & 97.400 & 1.340 & .541 & 6.740 & 18.700 & 1.870 & 155.000 & 137.000 & 7.680 & 10.100 & 1.990 & & \\
\hline fo1s & .863 & $\begin{array}{l}2.290 \\
2.630\end{array}$ & $\begin{array}{l}115.000 \\
178.000\end{array}$ & $\begin{array}{r}4.110 \\
4.910\end{array}$ & $\begin{array}{l}551.000 \\
916000\end{array}$ & $\begin{array}{l}44.200 \\
33.200\end{array}$ & $\begin{array}{r}33.500 \\
53.600\end{array}$ & $\begin{array}{l}70.100 \\
\end{array}$ & $3 . n 60$ & .893 & 6.230 & . 670 & .910 & 180.000 & 1010.000 & 8.520 & 28.800 & $1 . \times 40$ & 1.390 & 1.150 \\
\hline Fo22 & .736 & 3.060 & 90.900 & $2: 470$ & $5+4: 000$ & $\begin{array}{l}32: 8000 \\
32: 200\end{array}$ & $\begin{array}{l}51.600 \\
94.500\end{array}$ & $\begin{array}{l}127.000 \\
139: 000\end{array}$ & $\begin{array}{l}2.350 \\
2 ., 1>0\end{array}$ & $\begin{array}{l}7.745 \\
: 791\end{array}$ & $\begin{array}{l}7.1300 \\
7: 160\end{array}$ & $\begin{array}{l}18.000 \\
17.000\end{array}$ & $\begin{array}{l}2.010 \\
1.900\end{array}$ & $\begin{array}{l}052.000 \\
621.000\end{array}$ & $\begin{array}{l}1160.0000 \\
1360000\end{array}$ & $\begin{array}{l}8.310 \\
9.170\end{array}$ & $\begin{array}{l}37.000 \\
64: 100\end{array}$ & :AAS & $\left\{\begin{array}{l}1100 \\
1: 210\end{array}\right.$ & $\begin{array}{r}\therefore 990 \\
\therefore 780\end{array}$ \\
\hline $\begin{array}{l}y_{176} \\
1177\end{array}$ & .751 & $\begin{array}{l}2.160 \\
2.510\end{array}$ & $\begin{array}{r}15.000 \\
\end{array}$ & 2. $A 20$ & 379.0100 & 37.200 & $\begin{array}{r}5.900 \\
.5900\end{array}$ & $1, A .000$ & 2.910 & 1.120 & 7.950 & 18.100 & & 990.000 & 1050.000 & 8.470 & 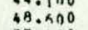 & & i.igo & 1.370 \\
\hline 1180 & $\begin{array}{l}1.030 \\
1.710\end{array}$ & $\begin{array}{l}2.510 \\
2.400\end{array}$ & $\begin{array}{l}120 . \\
97\end{array}$ & $\begin{array}{r}7.370 \\
8.10\end{array}$ & $\begin{array}{r}569 \cdot .100 \\
1010\end{array}$ & in & 40.400 & 112.000 & 3.190 & .793 & 7.140 & 14.300 & & $\$ 29.000$ & 1270.000 & 7.360 & 37.100 & & .950 & 1.180 \\
\hline$i{ }_{11 A 1}$ & .961 & 1.530 & $\begin{array}{r}19.8000 \\
138.000\end{array}$ & $4: 760$ & $\begin{array}{r}0107.000 \\
6000\end{array}$ & $\begin{array}{l}25.900 \\
29.800\end{array}$ & 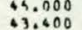 & $\begin{array}{l}132.000 \\
145.000\end{array}$ & $\begin{array}{l}2,000 \\
2: 050\end{array}$ & $\begin{array}{r}8799 \\
: 993\end{array}$ & $\begin{array}{r}10.200 \\
6.990\end{array}$ & $\begin{array}{l}15.000 \\
16.400\end{array}$ & & $\begin{array}{l}568.000 \\
6960000\end{array}$ & $\begin{array}{l}1170.000 \\
1150.000\end{array}$ & & $\begin{array}{l}35.700 \\
54.300\end{array}$ & & $\begin{array}{r}900 \\
9030\end{array}$ & $\begin{array}{l}1.650 \\
1.220\end{array}$ \\
\hline 11 月 & 1.560 & 2.090 & 917.200 & $\because 250$ & 951.000 & 25.000 & $\begin{array}{r}4.000 \\
\end{array}$ & 129.000 & $\begin{array}{l}2.0500 \\
1.910\end{array}$ & .781 & 9.240 & $\begin{array}{l}15.4000 \\
15.500\end{array}$ & & 532.000 & $\begin{array}{l}150.000 \\
1090.000\end{array}$ & $\begin{array}{l}.350 \\
6.510\end{array}$ & $\begin{array}{l}56,2000 \\
35.000\end{array}$ & (a19 & $\begin{array}{l}1.1370 \\
.990\end{array}$ & $\begin{array}{l}1.080^{\circ} \\
1.89\end{array}$ \\
\hline & $\begin{array}{l}1.196 \\
1.090\end{array}$ & $\begin{array}{l}2.610 \\
2.340\end{array}$ & & $\begin{array}{l}3.080 \\
4.000\end{array}$ & & 27.100 & 4.700 & 99.100 & 1.740 & .813 & 10.700 & 12.700 & 1.550 & 1190.000 & 933.000 & 6.860 & 38.000 & .662 & .990 & .940 \\
\hline fo36 & .848 & 3.150 & $\begin{array}{l}133.000 \\
165.000\end{array}$ & $\begin{array}{l}8.6000 \\
4.790\end{array}$ & 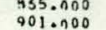 & $\begin{array}{l}24.6000 \\
30.900\end{array}$ & $\begin{array}{l}37.400 \\
39 ; 000\end{array}$ & $\begin{array}{r}79.500 \\
100^{2}\end{array}$ & $\begin{array}{l}1.550 \\
1.50\end{array}$ & $\begin{array}{r}.540 \\
0.551\end{array}$ & $\begin{array}{l}6.6110 \\
3.260\end{array}$ & $\begin{array}{l}11.300 \\
15.300\end{array}$ & $\begin{array}{l}1.600 \\
1.550\end{array}$ & $\begin{array}{r}4+8.000 \\
5.5000\end{array}$ & $\begin{array}{r}554.000 \\
\end{array}$ & 6.530 & 23.500 & & .920 & 1.120 \\
\hline 1179 & 1.320 & 2.250 & 113.000 & 2.160 & 538.000 & $\begin{array}{l}0.900 \\
27.900\end{array}$ & $\begin{array}{r}30.900 \\
39.400\end{array}$ & 127.000 & $\begin{array}{l}1.980 \\
1,100\end{array}$ & $\begin{array}{l}6512 \\
.771\end{array}$ & $\begin{array}{l}3.2600 \\
9.540\end{array}$ & $\begin{array}{l}15.300 \\
16.800\end{array}$ & & $\begin{array}{l}505.500 \\
522.000\end{array}$ & $\begin{array}{l}570.000 \\
1180.000\end{array}$ & $\begin{array}{l}8.180 \\
7.160\end{array}$ & $\begin{array}{l}38.500 \\
37.500\end{array}$ & & $\begin{array}{l}1.100 \\
9000\end{array}$ & $\begin{array}{l}1.22170 \\
1.250\end{array}$ \\
\hline $\begin{array}{l}1182 \\
162\end{array}$ & .95 & 2.77 & 134.000 & A. 2600 & 940.000 & 34.000 & 50.000 & $16 R .000$ & 2.450 & 897 & $7: 580$ & 16.700 & & 720.000 & 1500.000 & 9.360 & 49.410 & 1.590 & 1.050 & 2.120 \\
\hline 217 & .736 & $\begin{array}{l}2.070 \\
2.220\end{array}$ & 137.000 & $\begin{array}{r}5.660 \\
4.100\end{array}$ & $\begin{array}{l}650.000 \\
657.000\end{array}$ & $\begin{array}{l}24.000 \\
29.200 \\
29.200\end{array}$ & $\begin{array}{l}5.500 \\
55,500\end{array}$ & $\begin{array}{r}89.500 \\
\end{array}$ & $\begin{array}{l}1.920 \\
2.240\end{array}$ & .596 & $\begin{array}{l}7.090 \\
7.000\end{array}$ & 16.100 & $\begin{array}{l}1.650 \\
1.670\end{array}$ & 751.000 & 860.000 & 7.190 & 35.200 & 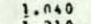 & .960 & 3.210 \\
\hline 218 & 1.760 & 1.920 & 111.000 & $\because .590$ & $\begin{array}{l}051.000 \\
\text { osion }\end{array}$ & 25.900 & $\begin{array}{l}5.4000 \\
69.200\end{array}$ & $\begin{array}{l}18,3.000 \\
115.000\end{array}$ & $\begin{array}{l}2,240 \\
1,770\end{array}$ & $\begin{array}{l}733 \\
.740\end{array}$ & $\begin{array}{l}7.6000 \\
10.900\end{array}$ & $\begin{array}{l}19.200 \\
13.600\end{array}$ & $\begin{array}{l}1.870 \\
1.390\end{array}$ & $\begin{array}{l}802.000 \\
693.000\end{array}$ & $\begin{array}{l}1070.000 \\
1000\end{array}$ & $\begin{array}{l}\begin{array}{l}8.930 \\
7.010\end{array} \\
7.010\end{array}$ & $\begin{array}{l}40.700 \\
38.300\end{array}$ & $\begin{array}{l}1.310 \\
9996\end{array}$ & $\begin{array}{l}1.270 \\
.070\end{array}$ & $\begin{array}{l}i: 1700 \\
1.550\end{array}$ \\
\hline 221 & 1.6 & 1.960 & ${ }^{86 .}$ & 3.220 & 659.000 & 27.700 & 57.900 & 114.000 & 2.050 & .020 & 10.400 & 14.000 & 1.320 & 640.000 & $i_{320.000}$ & 7.540 & $39.7 n 0$ & & $1 \operatorname{lnAD}_{1}$ & $\begin{array}{l}1: 870 \\
1: 870\end{array}$ \\
\hline 1352 & $\begin{array}{l}8.876 \\
.632\end{array}$ & $\begin{array}{l}1.500 \\
2.500\end{array}$ & $\begin{array}{l}110.0000 \\
95.000\end{array}$ & $\begin{array}{r}8.250 \\
3,480\end{array}$ & $\begin{array}{l}\text { 9AB } .00 \\
5311\end{array}$ & $\begin{array}{l}18.100 \\
33.700\end{array}$ & $\begin{array}{l}45.400 \\
0,400\end{array}$ & 107.000 & 1.580 & .093 & 5.600 & 18.000 & 1.640 & 355.000 & 1190.000 & 3.920 & $23.09 n$ & .977 & . $A>0$ & 1,260 \\
\hline вคO & $1: 180$ & 1.050 & $\begin{array}{r}95.000 \\
92.200\end{array}$ & $\begin{array}{l}3.460 \\
6.330\end{array}$ & $\begin{array}{l}531.000 \\
921.0 n 00\end{array}$ & $\begin{array}{l}39.700 \\
3 i=000\end{array}$ & $\begin{array}{l}32.000 \\
4: 400\end{array}$ & $\begin{array}{r}16 k .000 \\
89.600\end{array}$ & $\begin{array}{l}2.000 \\
1,900\end{array}$ & $\begin{array}{l}.891 \\
.709\end{array}$ & $\begin{array}{l}7.740 \\
6.060\end{array}$ & $\begin{array}{r}19.700 \\
12.000\end{array}$ & $\begin{array}{r}2.470 \\
.77 \%\end{array}$ & $\begin{array}{r}\mathrm{A} 98.0000 \\
110.000\end{array}$ & $\begin{array}{l}1670.000 \\
11770.000\end{array}$ & $\begin{array}{r}10.200 \\
7 \text { BAO }\end{array}$ & 52.000 & 1.230 & 1.350 & $\begin{array}{l}1.050 \\
3.110\end{array}$ \\
\hline 29 & $.71 ?$ & 2.440 & 119.000 & 5.000 & $1140 . \cap \cap 0$ & 31.200 & & 82,000 & 1.560 & .710 & $\because 900$ & 12.500 & $\begin{array}{l}17230 \\
1.230\end{array}$ & 600.000 & $\begin{array}{l}1710.000 \\
141000\end{array}$ & $\begin{array}{l}7.0 \text { AO } \\
\text { A. } 050\end{array}$ & 39.800 & & \begin{tabular}{l}
951 \\
\hdashline$O A 0$
\end{tabular} & 2.500 \\
\hline $\begin{array}{l}35 \\
36\end{array}$ & 9 & $\begin{array}{l}2.500 \\
3.290\end{array}$ & 160 & 5.300 & 12) & 31. & & 03.000 & 1.9 & .790 & 6.600 & 13.600 & 1.580 & 648.000 & 1110.000 & 7. & 38.700 & .410 & .9 & 3.500 \\
\hline 25 & .970 & 2.420 & 135.000 & $\begin{array}{l}5.600 \\
5.600\end{array}$ & 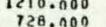 & 30 & & 94.000 & 1.9 & . ${ }^{A 20}$ & 7.800 & 12.500 & 30 & 887.600 & 13 & 7. & $\circ$ & & 930 & 3.370 \\
\hline 2 & $\because 10$ & 2.050 & 123.000 & 4.500 & $\begin{array}{l}1270.0000 \\
127000\end{array}$ & $\begin{array}{l}39.100 \\
29.600\end{array}$ & & $\begin{array}{l}94.000 \\
93.000\end{array}$ & $\frac{1.9}{2,3}$ & $8<0$ & $\begin{array}{l}8.200 \\
7.100\end{array}$ & $\begin{array}{r}33.200 \\
\end{array}$ & $\begin{array}{l}1.620 \\
1,670\end{array}$ & $\begin{array}{r}605.000 \\
135.000\end{array}$ & 1270 & $7: 1$ & & . 590 & $\therefore .950^{\circ}$ & $\begin{array}{r}4.2000 \\
940\end{array}$ \\
\hline 271 & .849 & 1.410 & 52.300 & 1.720 & TAR & 29.300 & 52.500 & 117.000 & 2.040 & Ths & 9,370 & 12.000 & 2.380 & $\begin{array}{l}1440.000 \\
\end{array}$ & $\begin{array}{l}1270.0000 \\
1270.000\end{array}$ & 7.620 & $\begin{array}{r}16.300 \\
49.000\end{array}$ & : & .980 & $\therefore 270$ \\
\hline 32 & $\begin{array}{l}710 \\
-793\end{array}$ & $\begin{array}{l}2.440 \\
2.980\end{array}$ & 102. & $\begin{array}{l}3.600 \\
4.300\end{array}$ & 1160. & 35. & & 102.000 & 2.000 & .530 & 5.200 & 16.300 & 1.300 & 585.000 & 1300.000 & A.610 & 48.100 & 670 & 1.070 & 1.460 \\
\hline 1231 & $1: 510$ & $\begin{array}{l}1.9670 \\
1.670\end{array}$ & $\begin{array}{r}144.000 \\
62.700\end{array}$ & $\begin{array}{r}\quad \begin{array}{r}200 \\
4510\end{array} \\
\end{array}$ & $\begin{array}{l}821.00100 \\
48: n 00\end{array}$ & $\begin{array}{l}36.200 \\
21: 000\end{array}$ & $\begin{array}{l}51,000 \\
32: 900\end{array}$ & $\begin{array}{l}135.000 \\
129: 000\end{array}$ & $\begin{array}{l}2.2500 \\
0,780\end{array}$ & $\begin{array}{r}705 \\
.651\end{array}$ & $\begin{array}{r}6.600 \\
13.300\end{array}$ & $\begin{array}{l}18.100 \\
11.000\end{array}$ & $\begin{array}{l}1.290 \\
2.360\end{array}$ & $\begin{array}{r}335.000 \\
1270.000\end{array}$ & 1440.000 & $8 .+40$ & 37.900 & $\therefore$. 339 & 1.170 & $\begin{array}{r}2.820 \\
2.560\end{array}$ \\
\hline 30 & .162 & .570 & 43.000 & 4.100 & 191.000 & 23.100 & & 81.000 & $\begin{array}{l}1.9300 \\
1.420\end{array}$ & :600 & $\begin{array}{l}11.800 \\
11.000\end{array}$ & $\begin{array}{l}11.600 \\
14.100\end{array}$ & $\begin{array}{l}2.360 \\
2.410\end{array}$ & 1620.000 & $\begin{array}{l}508.000 \\
196.000\end{array}$ & $\begin{array}{l}6.2 \\
3.7\end{array}$ & $\begin{array}{l}38 . \ln 0 \\
20 . \ln 0\end{array}$ & & $\begin{array}{r}.947 \\
1.300\end{array}$ & $\begin{array}{l}2.560 \\
1.540\end{array}$ \\
\hline${ }^{59}$ & 1020 & 1.210 & 25.000 & 1.200 & 559.100 & 36.300 & & 79.000 & 1.150 & .510 & 5.510 & 10.200 & .920 & 921.000 & 755.000 & 8.960 & 47.200 & & $i: 090$ & 1.110 \\
\hline 8. & $\begin{array}{l}1.020 \\
.830\end{array}$ & $\begin{array}{l}1.630 \\
1.730\end{array}$ & $\begin{array}{r}6550 \\
180: 0\end{array}$ & $\begin{array}{r}1.670 \\
\therefore 550\end{array}$ & $\begin{array}{l}628 . \\
540 .\end{array}$ & 0 & 54.000 & 197000 & 2. & & 14.7 & & 1.950 & 739.000 & 131 & 7.930 & & 1.150 & 1.150 & 1.570 \\
\hline 88 & 1.300 & 2.000 & 131.000 & $\begin{array}{l}7.210 \\
.210\end{array}$ & 772.000 & $\begin{array}{l}24.000 \\
35.200 \\
35.200\end{array}$ & $\begin{array}{l}49.000 \\
37.000\end{array}$ & 207.000 & $\begin{array}{r}1.910 \\
2 \geqslant 2040\end{array}$ & & $\begin{array}{l}6.000 \\
6.050\end{array}$ & $\begin{array}{l}15 . \\
14 .\end{array}$ & $\begin{array}{l}1.340 \\
1: 930\end{array}$ & $\begin{array}{r}500.000 \\
503,000\end{array}$ & $\begin{array}{l}1140.000 \\
\end{array}$ & $\begin{array}{r}7.230 \\
\end{array}$ & $\begin{array}{l}37 . \\
49\end{array}$ & $\begin{array}{l}.550 \\
; 940\end{array}$ & 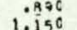 & $\begin{array}{l}0.680 \\
1.060\end{array}$ \\
\hline $2 M$ & .760 & 1.740 & 111.000 & 4.560 & 612.000 & 32.100 & 50.0100 & & i. B & & 16.20 & $13:$ & 1.580 & 580.000 & $\begin{array}{r}1320.000 \\
1320\end{array}$ & A, 780 & 42 & .450 & $\begin{array}{l}.950 \\
.950\end{array}$ & 6.500 \\
\hline & $\begin{array}{r}9 A_{2} \\
.652\end{array}$ & & & & & & 4.000 & 107.000 & 1.710 & .655 & & 10.500 & 1.590 & 1370.000 & 1610. & h. 8 & 50.100 & & & 5.080 \\
\hline 24 & $1.40^{\circ}$ & $\begin{array}{l}1.420 \\
1.980\end{array}$ & $\begin{array}{l}63.2 \\
96.2\end{array}$ & $\begin{array}{l}2.980 \\
3.830\end{array}$ & $\begin{array}{l}3 A 2 . \\
\text { A1 }\end{array}$ & 23. & $\begin{array}{l}37.400 \\
39.00\end{array}$ & ${ }_{10}^{80} \mathrm{i}^{\circ}$ & $\begin{array}{l}1.510 \\
1910\end{array}$ & 4 & 5.2 & 9.3 & $\begin{array}{l}1.720 \\
1.690\end{array}$ & $\begin{array}{l}914.000 \\
381,000\end{array}$ & & & & . A01 & & $\begin{array}{l}11.700 \\
2580\end{array}$ \\
\hline 32 & 1.190 & 2.740 & 101.000 & 6.720 & 705.0 & 25. & $\begin{array}{l}99: 400 \\
39: 100\end{array}$ & $\begin{array}{l}01.000 \\
8 \cap .500\end{array}$ & $\begin{array}{l}1.940 \\
1: k 20\end{array}$ & $\begin{array}{l}6820 \\
: 664\end{array}$ & $\begin{array}{l}5.600 \\
4.010\end{array}$ & 16.5 & $\begin{array}{l}1.6900 \\
1.350\end{array}$ & 620.000 & $\begin{array}{r}961 \\
.03\end{array}$ & $?$ & & 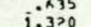 & $\begin{array}{l}1.150 \\
.740\end{array}$ & $\begin{array}{l}.3500 \\
1.320\end{array}$ \\
\hline (3) & 0 & $\therefore 7$ & 17. & .200 & 211.0 & 19. & 43.500 & 89.500 & 1.9 & .676 & 15.000 & 16. & 2.140 & 1910.000 & 216 & 6.810 & 4 & .500 & 1.330 & .4 \\
\hline & $\begin{array}{l}1143 \\
1.140\end{array}$ & $\begin{array}{l}1.0<0 \\
1.880\end{array}$ & $\begin{array}{l}57.9 \\
57: 9\end{array}$ & $\begin{array}{r}2.870 \\
2.8 A 0\end{array}$ & & & $4 \div 900$ & & 1.9 & .582 & & & 2.080 & & & & & & & \\
\hline 23 & .964 & 2.510 & 78.4 & $\begin{array}{l}2.880 \\
? .950\end{array}$ & $\begin{array}{l}3960.7 \\
743.0\end{array}$ & 年 & $\begin{array}{l}7.000 \\
31: 500\end{array}$ & $\begin{array}{l}134,000 \\
105.000\end{array}$ & $\begin{array}{l}2.2 \\
1.92\end{array}$ & $\begin{array}{l}1.010 \\
.549\end{array}$ & 6.0 & & & & & 10. & & & & $\begin{array}{l}1.920 \\
7.630\end{array}$ \\
\hline 8336 & .025 & .155 & 20.100 & .200 & 126.000 & 19.300 & 33.600 & $\begin{array}{l}133.000 \\
\end{array}$ & $\begin{array}{l}1.950 \\
1.370\end{array}$ & .566 & 13.000 & 16.000 & 1.260 & 2260.000 & $\begin{array}{l}685 \\
730 \\
730\end{array}$ & B. & & .454 & $\begin{array}{l}1.130 \\
1.400\end{array}$ & .300 \\
\hline & $\begin{array}{l}1.350 \\
.350 \\
710\end{array}$ & $\begin{array}{l}1.9 \\
2.0\end{array}$ & 104. & A.100 & 5 & 29.5 & & 71.000 & 1.7 & .500 & 6.9 & 10.0 & 1.520 & 1510 & 506 & & & .740 & & 1.530 \\
\hline 16 & $: 732$ & $1: 750$ & $\begin{array}{l}111.0 \\
156 \% 0\end{array}$ & $\begin{array}{r}5.100 \\
4.260\end{array}$ & $\begin{array}{r}1200.000 \\
999 \cdot 000\end{array}$ & (3): & & $a^{94}$ & 1.0 & .64 & & & $\begin{array}{l}1.220 \\
1.200\end{array}$ & $\begin{array}{l}21160.0000 \\
1170.000\end{array}$ & $\begin{array}{l}920 \\
1320\end{array}$ & 9. & & $.4 ? 0$ & & \\
\hline 16 & 1.150 & 1.430 & 103.0 & 3.560 & BAS. กOQ & $\begin{array}{l}30.900 \\
30.900\end{array}$ & $\begin{array}{l}0.0000 \\
45.400\end{array}$ & 90.6 & 2.1 & .642 & 9.0 & $\begin{array}{l}13.0 \\
12.6\end{array}$ & $\begin{array}{l}1.370 \\
1.370\end{array}$ & 1970.000 & $\begin{array}{r}1090 \\
724\end{array}$ & 9. & & & 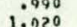 & $\begin{array}{l}1.530 \\
1.530\end{array}$ \\
\hline$=0$ & .616 & $\begin{array}{l}2.020 \\
2.400\end{array}$ & 81.500 & $\begin{array}{r}4.980 \\
4\end{array}$ & $\begin{array}{l}935.100 \\
063\end{array}$ & 30.4 & 40.000 & 75.900 & 1.930 & .584 & 0.2 & 10.4 & 1.350 & 664 & 670 & & & & & \\
\hline Foss & 1.190 & 2.430 & 132.000 & $\begin{array}{l}5.030 \\
5.030\end{array}$ & 530.000 & 1,900 & \begin{tabular}{l}
3.000 \\
\hdashline$\quad 0000$
\end{tabular} & 89. & & .50 & & & & & & & & & & \\
\hline & . ABO & .96 & $B A: 0$ & C;AOO & $\begin{array}{r}530.0100 \\
1120.000\end{array}$ & $\begin{array}{ll}0 \\
: 000\end{array}$ & 1". & & 1.9 & .65 & & & & & & & & & & 3.190 \\
\hline & 1.180 & 2.110 & 70.000 & 4.200 & 1510.000 & 37,000 & & 0.000 & $\begin{array}{l}2.04 \\
2.70\end{array}$ & 83 & $\because:$ & & $30^{3}$ & & 100 & & & 0 & & 1.840 \\
\hline 16 & 1.316 & $=110$ & 109.0 & 4.700 & 966.000 & 30.700 & & 91. & 2.0 & .11 & 5. & & $1 \cdot 4$ & 496 & 966.000 & & $3^{3}$ & & in & 2.040 \\
\hline 34 & i. 0 & & & 年, 390 & $11+0$ & on & i.? & & & & & & & & & & & & & \\
\hline & Me & .7 & 46 & 4.230 & 739. & 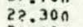 & & 110 & & & & & & & & & & & & \\
\hline $\begin{array}{l}\begin{array}{l}1235 \\
F 051\end{array} \\
\text { F }\end{array}$ & $\begin{array}{l}1.200 \\
1.080\end{array}$ & $\begin{array}{l}2.790 \\
2.500\end{array}$ & $\begin{array}{l}120.000 \\
00\end{array}$ & $\begin{array}{r}.520 \\
0.5950\end{array}$ & $\begin{array}{r}750 \cdot n 00 \\
552\end{array}$ & 32,0 & 0.00 & 114.000 & $\because$ & 529 & 3.75 & $\because$ & 2.270 & 0.02 .00 & 190 & . & 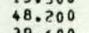 & " & 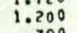 & \\
\hline
\end{tabular}

$$
\begin{aligned}
& \text {, Table I c } \\
& \text { BNL 4-809-80 }
\end{aligned}
$$




\section{TABLE}

Q-MODE SCALED VARIMAX FACTOR SCORES

\begin{tabular}{|c|c|c|c|}
\hline Variable & Q-Factor 1 & Q-Factor 2 & Q-Factor 3 \\
\hline $\mathrm{Na}$ & 0.38 & 1.16 & -0.67 \\
\hline $\mathrm{K}$ & 0.48 & 2.07 & -0.37 \\
\hline $\mathrm{Rb}$ & 0.63 & 0.82 & 0.33 \\
\hline $\mathrm{Cs}$ & -0.19 & 1.32 & -0.13 \\
\hline $\mathrm{Ba}$. & -0.08 & 1.04 & 0.68 \\
\hline $\mathrm{Sc}$ & 0.37 & 0.98 & 0.84 \\
\hline $\mathrm{Eu}$ & 0.23 & 0.56 & 1.33 \\
\hline $\mathrm{Lu}$ & 2.38 & -1.36 & 0.52 \\
\hline $\mathrm{Hf}$ & 0.72 & 0.03 & 2.25 \\
\hline Th & 0.53 & 0.61 & 0.75 \\
\hline $\mathrm{Cr}$ & 1.01 & -0.43 & -0.06 \\
\hline Mn & 1.61 & 0.47 & -2.08 \\
\hline $\mathrm{Fe}$ & 0.83 & 0.97 & 0.28 \\
\hline Co & 1.50 & -0.21 & -0.30 \\
\hline Variance & 44.90 & 43.46 & 5.87 \\
\hline $\begin{array}{l}\text { Cumulative } \\
\text { Variance }\end{array}$ & 44.90 & 88.35 & 94.23 \\
\hline
\end{tabular}


TABLE 3

R-MODE FACTOR COMMUNALITY ESTIMATES

\begin{tabular}{|c|c|c|c|c|c|}
\hline Pass & 1 & 2 & 3 & 4 & 5 \\
\hline $\begin{array}{l}\text { Number of } \\
\text { Factors }\end{array}$ & 5 & 4 & 4 & 4 & 4 \\
\hline $\begin{array}{l}\text { Variance } \\
\text { Accounted }\end{array}$ & $81 \%$ & $74 \%$ & $77 \%$ & $79 \%$ & $80 \%$ \\
\hline $\mathrm{Ne}$ & .892 & .597 & .726 & .769 & .817 \\
\hline $\mathrm{K}$ & .750 & .654 & .640 & .672 & .699 \\
\hline $\mathrm{Rl}$ & .878 & .771 & .751 & .793 & .764 \\
\hline Cs & .851 & .702 & .749 & .753 & .867 \\
\hline $\mathrm{Ba}$ & .619 & .428 & .484 & .450 & .587 \\
\hline Sc & .826 & .892 & .926 & .928 & .927 \\
\hline Ev & .801 & .804 & .805 & .845 & .825 \\
\hline Hf & .687 & .814 & .837 & .867 & .856 \\
\hline $\mathrm{TH}$ & .827 & .860 & .895 & .915 & .885 \\
\hline $\mathrm{Cr}$ & .8333 & .759 & .793 & .810 & .712 \\
\hline$F \in$ & .862 & .830 & .839 & .857 & .875 \\
\hline $\mathrm{Co}$ & .858 & .817 & .812 & .771 & 734 \\
\hline
\end{tabular}

Nurber of

Specimens

Removed ${ }^{2}$.

22

20

13.

14

9

Notes: 1 Factors extracted with eigenvalues greater than 1.00 .

2 Specimens removed when laying outside a $95 \%$ confidence region from centroid. 


\section{TABLE 웅}

STANDARDIZED DISCRIMINANT FUNCTION COEFFICIENTS FOR CHEMICAL PASTE COMPOSITIONAL REFERENCE UNITS

\begin{tabular}{|c|c|c|c|c|c|}
\hline Vari & iable & DE 1 & $\mathrm{DF} 2$ & $\mathrm{DF} 3$ & DF 4 \\
\hline & $\mathrm{Na}$ & 0.24 & 0.01 & 0.32 & 0.28 \\
\hline K & & -0.63 & -0.22 & 0.17 & 0.10 \\
\hline & ib & $=1 . ; 1$ & 0.70 & $=0 ; 2 ?$ & 0.10 \\
\hline & is & 0.42 & $=0.64$ & 1.03 & 0.24 \\
\hline & $3 a$ & -0.18 & -1.10 & -1.35 & -0.22 \\
\hline & Sc & -0.57 & 0.86 & -0.95 & -1.00 \\
\hline & Eu & 0.27 & -0.81 & -0.09 & -0.63 \\
\hline I & us & 0.18 & -0.04 & -0.04 & -0.22 \\
\hline $\mathrm{H}$ & & -0.58 & -1.07 & 0.10 & 0.24 \\
\hline$T$ & Sh & -1.30 & 0.23 & .0 .37 & -0.54 \\
\hline C & ir & -0.81 & 0.81 & -0.11 & -0.25 \\
\hline M & In & -0.16 & -0.68 & -0.15 & 0.26 \\
\hline F & e & 0.03 & -0.13 & 0.94 & 1.00 \\
\hline $\mathrm{C}$ & Co & 0.39 & -0.21 & -0.01 & 0.50 \\
\hline $\mathrm{T}$ & $i$ & 0.25 & 0.22 & 0.29 & -0.04 \\
\hline Eigenval & Lue & 7.36 & 4.30 & 2.23 & 1.42 \\
\hline Trace & $U_{1}$ & 48.1 & 28.1 & 14.6 & 9.3 \\
\hline
\end{tabular}


TABLE 5

STANDARDIZED DISCRIMINANT FUNCTION

COEFFICIENTS FOR PASTE COMPOSITIONAL REFERENCE UNITS

\begin{tabular}{|c|c|c|}
\hline Variable & $D F 1$ & DF 2 \\
\hline $\mathrm{Na}$ & -0.27 & -0.17 \\
\hline $\mathrm{K}$ & 0.49 & -0.21 \\
\hline $\mathrm{Rb}$ & 1.47 & 0.64 \\
\hline Cs & -0.77 & -0.32 \\
\hline $\mathrm{Ba}$ & 0.06 & -0.55 \\
\hline Sc & 1.01 & -0.63 \\
\hline Eu & -0.52 & 0.16 \\
\hline Lu & -0.18 & 0.17 \\
\hline $\mathrm{Hf}$ & 0.21 & -0.74 \\
\hline Th & 1.21 & 0.52 \\
\hline $\mathrm{Cr}$ & 1.03 & 0.52 \\
\hline $\mathrm{Mn}$ & -0.02 & -0.58 \\
\hline $\mathrm{Fe} \quad:$ & -0.19 & -0.77 \\
\hline Co & -0.41 & -0.50 \\
\hline $\mathrm{Ti}$ & -0.22 & $0: 20$ \\
\hline Eigenvalue & 6.83 & 1.98 \\
\hline $\begin{array}{c}\text { Percent of } \\
\text { Trace }\end{array}$ & 77.5 & 22.5 \\
\hline
\end{tabular}




\section{TABLE 6}

STANDARDIZED DISCRIMINANT FUNCTION COEFFICIENTS FOR MAYAN FINE ORANGE-FINE GRAY AND OTHER FINE PASTE POTTERY

\begin{tabular}{|c|c|c|c|c|c|}
\hline Variable & DF 1 & DF 2 . & DF 3 & DF 4 & DF 5 \\
\hline $\mathrm{Na}$ & 0.27 & 0.17 & 0.81 & 0.53 & 0.40 \\
\hline K & -0.21 & 0.34 & -0.75 & -0.36 & -0.33 \\
\hline $\mathrm{Rb}$ & 0.82 & 0.62 & -0.15 & -0.76 & 0.32 \\
\hline Cs & -0.78 & -0.42 & 0.49 & 0.95 & -0.07 \\
\hline $\mathrm{Ba}$ & -0.38 & 0.02 & 0.14 & 0.36 & -0.31 \\
\hline $\mathrm{Sc}$ & -0.43 & 0.72 & 0.67 & 0.32 & -0.09 \\
\hline Eu & 0.02 & 0.22 & 0.54 & $0.28^{\circ}$ & 0.65 \\
\hline Hf & -0.28 & -0.28 & -0.40 & 0.35 & 0.76 \\
\hline $\mathrm{Th}$ & 0.48 & $0.66^{\circ}$ & -0.67 & -0.22 & -0.18 \\
\hline $\mathrm{Cr}$ & 1.59 & 1.60 & 1.65 & -0.44 & -0.26 \\
\hline Mn & 0.19 & -0.31 & -0.99 & 0.87 & -0.13 \\
\hline $\mathrm{Fe}$ & -0.37 & 0.37 & 0.21 & 0.42 & 0.19 \\
\hline Co & 1.00 & -1.31 & -0.38 & 0.62 & 0.30 \\
\hline 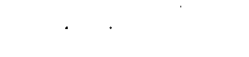 & . & & $\cdot$ & $:$ & \\
\hline Eigenvalue & 11.4 & 3.1 & 2.9 & 0.5 & 0.3 \\
\hline $\begin{array}{c}\text { Percent of } \\
\text { Trace }\end{array}$ & 62.3 & 17.2 & 16.1 & 2.8 & 1.4 \\
\hline
\end{tabular}


TABLE $\%$

SRECIMENS FROM THE MAYA AREA CONSIDERED IN THIS STUDY

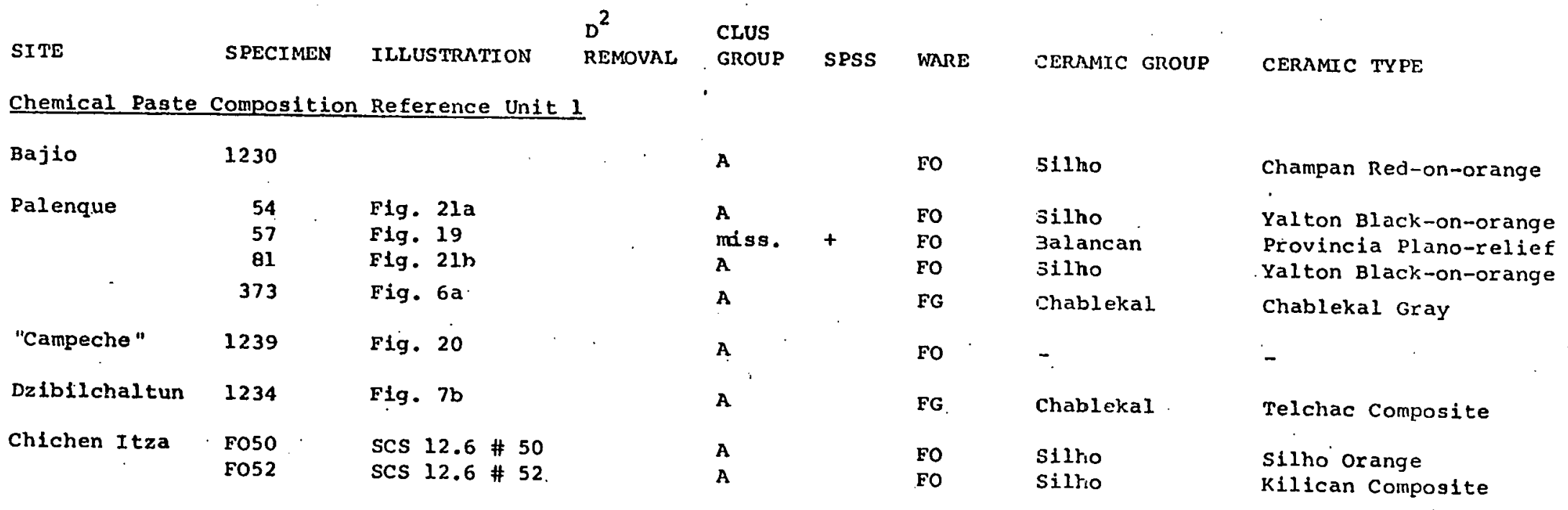




\section{TABLE 7.2}

SITE

$\begin{array}{lll} & & \\ \text { SPECIMEN ILLUSTRATION } & \text { REMOVAL } & \text { CLUS } \\ & & \end{array}$

Chemical Paste Composition Reference Unit 2

\begin{tabular}{|c|c|c|}
\hline Becan & 1010 & \\
\hline $\begin{array}{l}\text { Altar de } \\
\text { Sacrificios }\end{array}$ & FO49 & $\operatorname{scs} A .4 \neq 49$ \\
\hline Arenitas & 231 & Fig. 10a \\
\hline Trinidad & $\begin{array}{l}272 \\
273\end{array}$ & $\begin{array}{l}\text { Fig. 22D } \\
\text { Fig. 10ذ }\end{array}$ \\
\hline Calatrava & $\begin{array}{r}12 \\
229\end{array}$ & Fig. 9 \\
\hline
\end{tabular}

\section{B}

B

B

B

B

B
SPSS WRRE

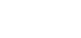

Fo

FG

FO

西

FO

FO

F'O

FO

FG
CERAMIC GROUP 
TABLE 7.3

SITE

SPECIMEN

ILLUSTRATION

$D^{2}$

CLUS

Chemical Paste Composition Reference Unit 3

\begin{tabular}{|c|c|c|c|c|c|}
\hline Uaxactun & FO42 & scs & $A-8 \#$ & 42 & \\
\hline & F043 & scs & $A-8 \#$ & 43 & \\
\hline El Cayo & FO46 & scs & $A-9 \#$ & 46 & \\
\hline Lubaantun & NH48 & & & & 4 \\
\hline SEIBAL & Fol6 & SCS & A.1 \# & 16 & \\
\hline & FOI7 & SCS & A.1 \# & 17 & \\
\hline & F018 & SCS & A.1 \# & 18 & \\
\hline & Fo19 & SCS & A.1 \# & 19 & \\
\hline & FO20 & SCS & A.1 \# & 20 & \\
\hline & FO25 & $\operatorname{scs}$ & A. $2 \#$ & 25 & \\
\hline Altar de & FO28 & $\operatorname{scs}$ & $12.1 \neq$ & \# 28 & : \\
\hline Sacrificios & F029 & SCS & $12.1 \neq$ & $\# 29$ & \\
\hline & F032 & SCS & $12.1 \neq$ & \# 32 & \\
\hline & F034 & $\operatorname{scs}$ & A. $3 \#$ & 34 & \\
\hline & F035 & $\operatorname{scs}$ & A. $3 \#$ & 35 & \\
\hline . & F037 & $\operatorname{scs}$ & A. $5 \#$ & 37 & \\
\hline 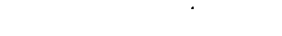 & FO38 & SCS & A. 5 \# & 38 & \\
\hline & F039 & & & & \\
\hline Piedras Negras & 219 & Fig & . 13 & & \\
\hline & 220 & & & & \\
\hline & 222 & & & & \\
\hline & 223 & & . & & \\
\hline . & 491 & & & & \\
\hline Jonuta & 1 & & & & \\
\hline & FO53 & Scs & A. $10 \neq$ & \# 53 & \\
\hline
\end{tabular}

\begin{tabular}{|c|c|c|c|}
\hline C & & Fo & Altar \\
\hline C & & Fo & Altar \\
\hline c & & FO & Altar \\
\hline & + & FO & Altar \\
\hline C & & FO & Altar \\
\hline C & & FO & Altar \\
\hline C & & FO & Altar \\
\hline C & & FO & Altar \\
\hline c & & FO & Altar \\
\hline $\mathrm{c}$ & & FO & Altar \\
\hline c & & FO & Altar \\
\hline C & & Fo & Altar \\
\hline C & & FO & Altar \\
\hline c & & Fo & Balancan \\
\hline C & & FO & Altar \\
\hline c & & Fo & - \\
\hline c & & Fo & - \\
\hline $\mathrm{c}$ & & FG & Tres Naciones \\
\hline c & & Fo & Altar \\
\hline C & & Fo & Altar \\
\hline$c$ & & FO & Altar \\
\hline c. & & Fo & Altar* \\
\hline miss. & + & FO & Altar \\
\hline c & & FO & - \\
\hline c & & Fo & - \\
\hline
\end{tabular}

Islas Gouged-incised* Altar orange

Pabellon Modeled-carved

Pabelion Modeled-carved

Pabellon Modeled-carved*

Islas Gouged-incised

Altar orange

Cedro Gadrooned

Altar Orange

Islas Gouged-incised

Pabellon Modeled-carved Pabellon Modeled-carved

Altar Orange

Provincia Plano-relief

Tumba Black-on-orange

Pabellon Modeled-carved Pabellon Modeled-carved Cedro Gadrooned

Pabellon Modeled-carved

$-$ 


\section{TABLE 7.4}

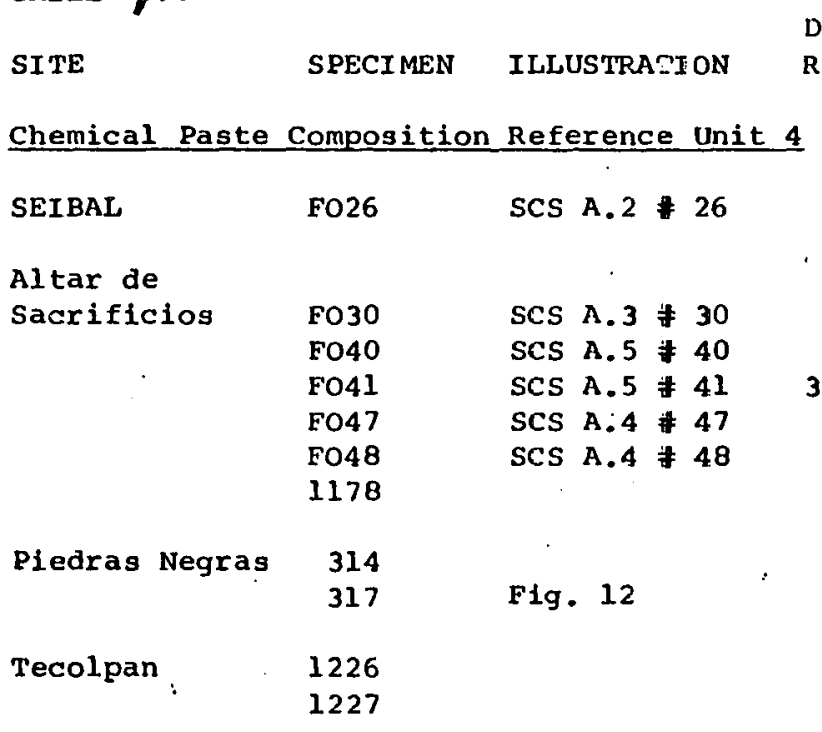

$D^{2} \quad$ CLUS

EMOVAL GROUP
SPSS

ps

\section{WARE}

CERAMIC GROUP

D

FG

Tres Naciones

Altax.

Tres $\mathbb{N a c i o n e s}$

Tres Naciones

Altar.

Altar.

Tres Naciones

Tres Naciones

Altar

Altax

Tres Naciones*
CERAMIC TYPE

Tres Naciones Gray

Altar orange

Tres Naciones Gray

Altar orange

Altar orange

Chorrito Plano-relief

Tres Naciones Gray

Altar Drange

Altar Drange

Tres Naciones Gray* 
TABLE 7.5

SITE

SPECIMEN ILLUSTRATION.

$\mathrm{D}^{2}$. CLUS

Chemical Paste Composition Reference Unit 5

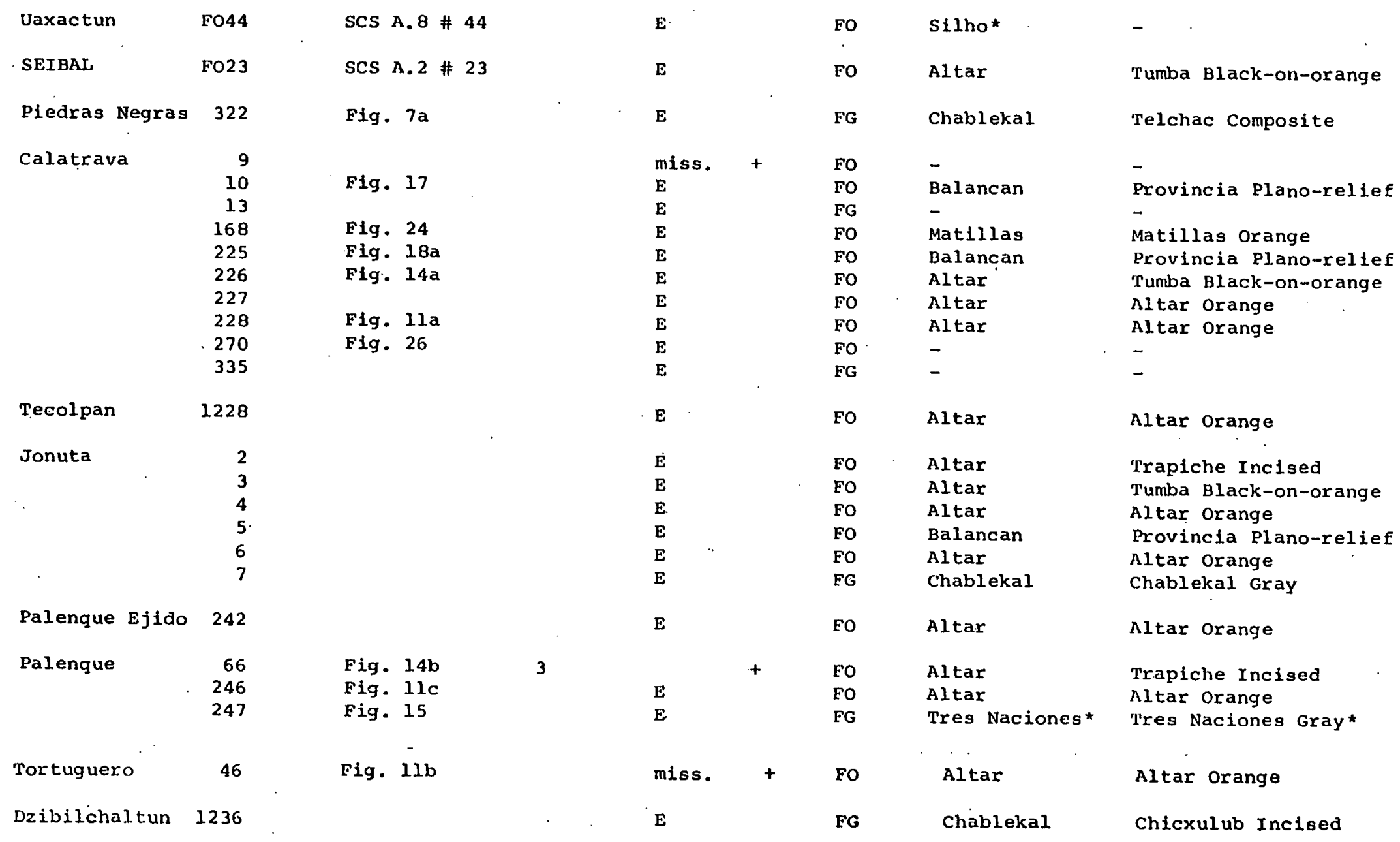


TABLE 7.6

SITE

SPECIMEN

ILLUSTRATION

D CLUS

REMOVAL GROUP

Tortuguero Reference Unit

$\begin{array}{lrrr}\text { Palenque } & 248 & & 3 \\ \text { Tortuguero } & 39 & & 3 \\ & 40 & & 3 \\ & 41 & & 2 \\ 42 & & 4 \\ 43 & \text { Fig. 5a } & 1 \\ & 44 & & 4 \\ 45 & \text { Fig. 18b } & 2 \\ & 47 & & \end{array}$

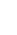

3

4

4
SPSS WARE CERAMIC GROUP CERAMIC TYPE 
TABLE 27

SITE

SPECIMEN

Unplaced Samples

Becan

1009

1011

1012

1237

1238

Yaxha

969

970

San Jose

F045

SEIBAL

Fols

FO22

1176

1177

1180

1181

1183

Altar de Sacrificios

FO31

ro33

F036

1179

1182

Piedras Negras 162

217

218

221

318

1352 $\begin{array}{lll}2 & \text { PROJECTED } \\ \text { MEMBERSHIP }\end{array}$

REMOVAL GROUP SPSS

GPCRU PCRU WARE

CERAMIC GROUP

CERAMIC TYPE

Altax

Balancan

Tres Naciones

Tres Naciones

Altar

Altar

Balancan

$\operatorname{scs} 12.1$ \# $31 \quad 3$

$\operatorname{scs} 12.1 \# 33 \quad 5$

SCS A. 3 \# 36

Fig. $16 b$

Fig. $16 a$

5

3

FO

Altar

Altar

Altar

Nltar

Altar

Chablekal

Balancen

Balancan

Altar

Altar
Pabellon Modeled-carved Provincia Plano-relief

Tres Naciones Gray

Poite Incised

Trapiche Incised

Pabellon Modeled-carved

Provincia Plano-relief

Altar orange

Altar orange

Islas Gouged-incised

Altar orange

Pabellon Modeled-carved

Chlcxulub Incised

Provincia Plano-relief Provincia Plano-relief

Trapiche Incised

Pabellon Modeled-carved 


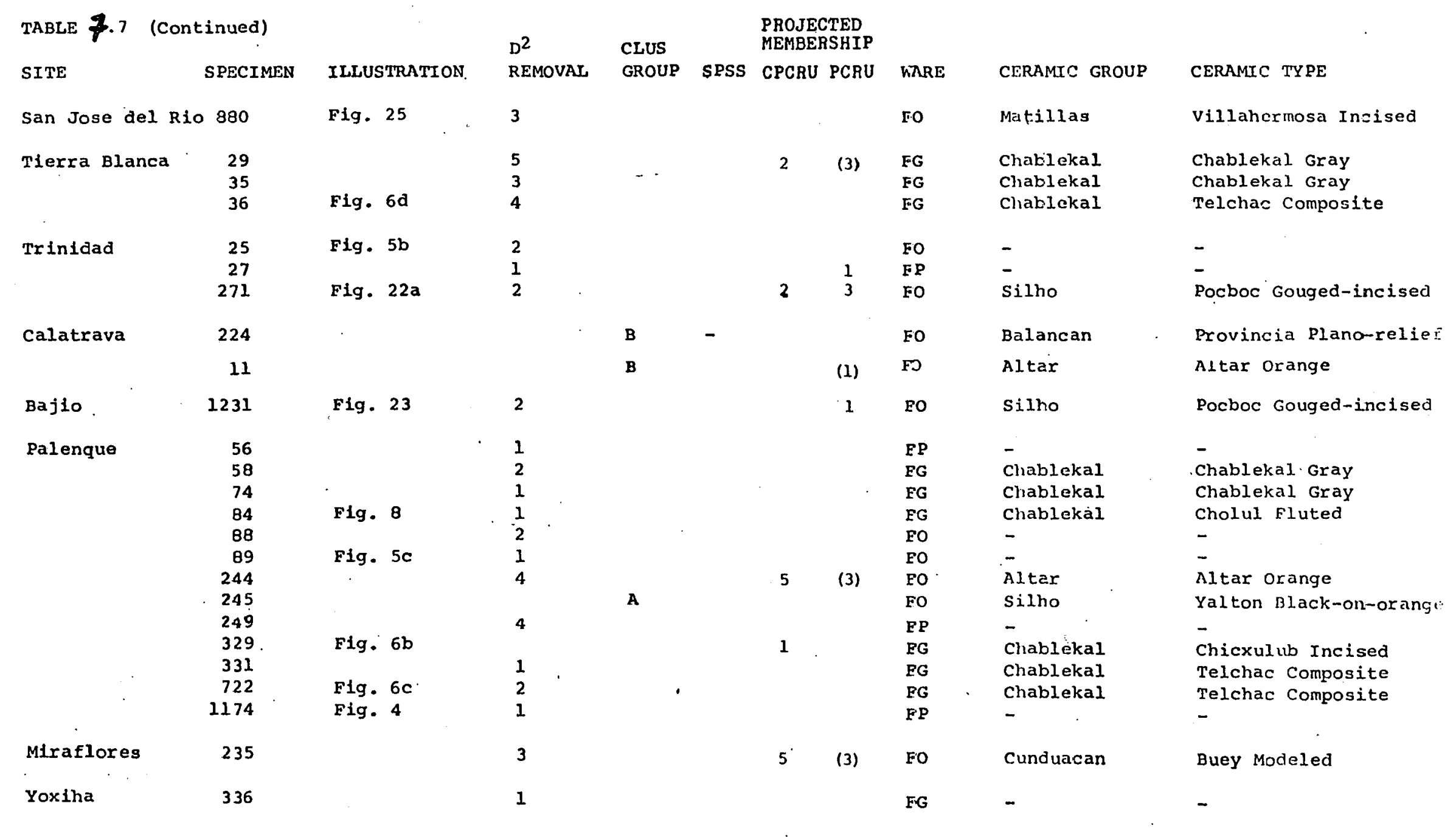




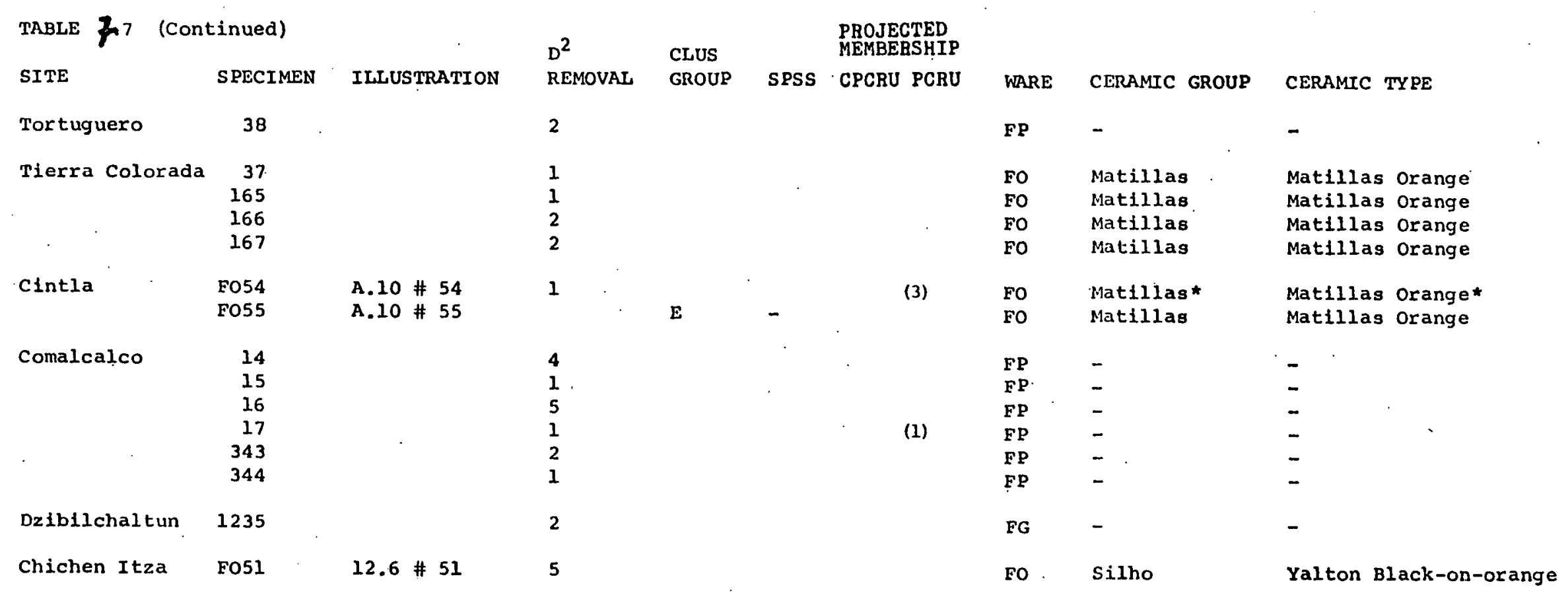


- table 8

TXPOLOGY AND COMPOSITIONAL GROUPINGS

\begin{tabular}{|c|c|c|c|c|c|c|c|c|c|c|}
\hline \multirow[t]{2}{*}{$\begin{array}{l}\text { CERAMIC GROUP/ } \\
\text { CERAMIC TYPE }\end{array}$} & \multicolumn{3}{|c|}{ PCRU } & \multicolumn{5}{|c|}{$\begin{array}{r}\text { CPCRU } \\
\text { "Usumacinta" }\end{array}$} & \multirow[t]{2}{*}{ JNPLACED } & \multirow[t]{2}{*}{$\begin{array}{l}\text { TORTU- } \\
\text { GUERO }\end{array}$} \\
\hline & 1 & 2 & 3 & 2 & 4 & 5 & 3 & 1 & & \\
\hline \multicolumn{11}{|l|}{ Altar Ceramic Group } \\
\hline Altar Orange & & 16 & 4 & 3 & 5 & 8 & 4 & & 5 & \\
\hline Cedro Gadrooned & & & 2 & & & & 2 & & & \\
\hline Islas Gouged-incised & & & $3^{*}$ & & & & $3^{*}$ & & 1 & . \\
\hline Pabelion Modeled-carved & & & $8^{*}$ & & & & $8^{*}$ & & 4 & \\
\hline Trapiche Incised & & 2 & & & & 2 & & & 2 & \\
\hline Tumba Black-on-orange & & 3 & 1 & & & 3 & 1 & & & \\
\hline Unspecified & & & 1 & & & & 1 & & & - \\
\hline Balancan Ceramic Group & & . & & & & & & & & \\
\hline Balancan orange & & & · & & & & & & & 1 \\
\hline Provincla Plano-rellef & 1 & 3 & 1 & & & 3 & 1 & 1 & 5 & 1 \\
\hline
\end{tabular}


TABLE 8 (continued)

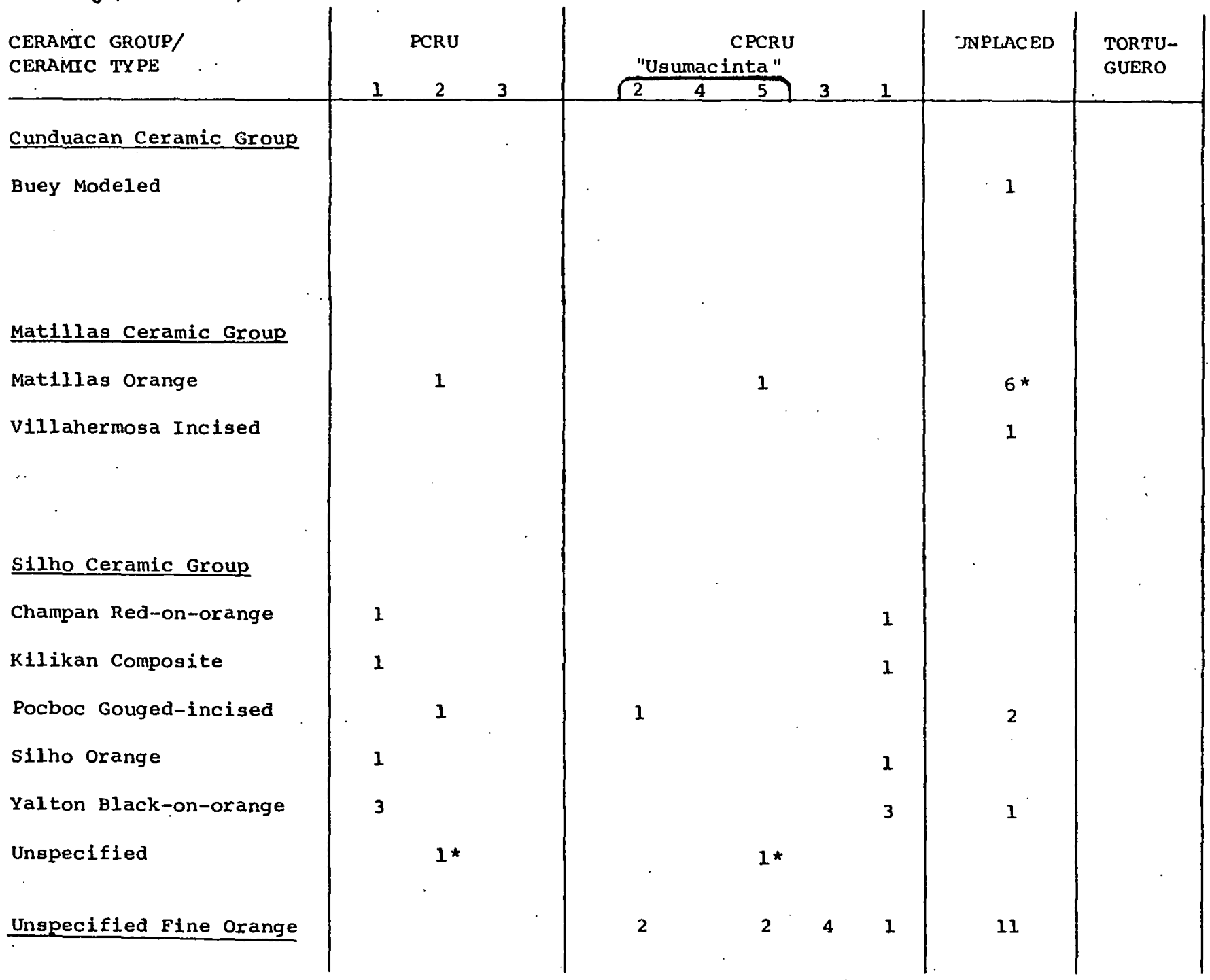


TABLE 8 (continued)

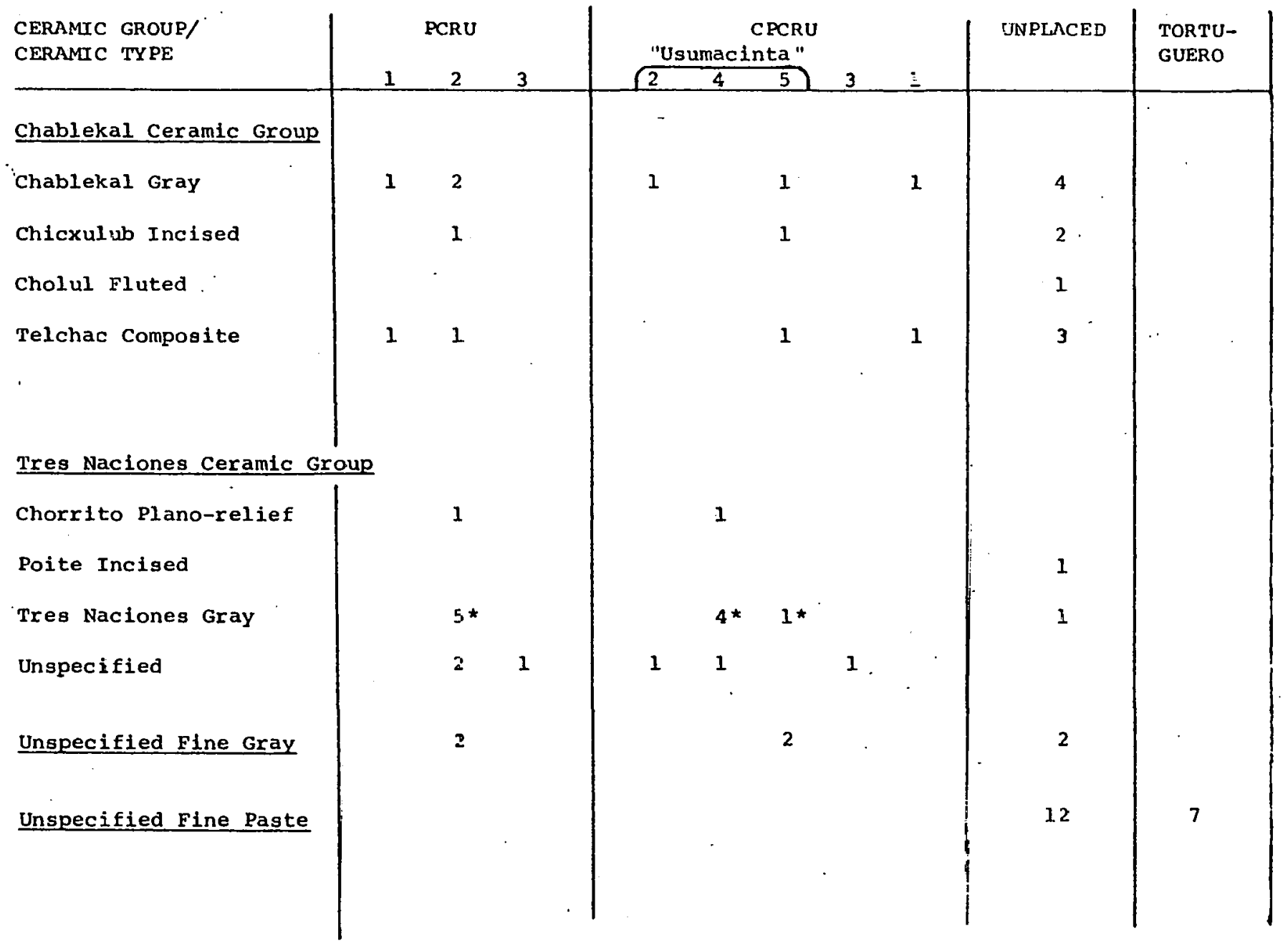


TABLE

PETROGRAPHIC VARIABLES

\begin{tabular}{|c|c|c|c|c|c|c|c|}
\hline SITE & SPECIMEN & $\begin{array}{l}\text { MICACEOUS } \\
\text { MATRIX }\end{array}$ & $\begin{array}{l}\text { VOLCANIC } \\
\text { DUST }\end{array}$ & FELDS PAR & WARE & CERAMIC GI:OUP & CERAMIC TYPE \\
\hline Becan & $\begin{array}{l}1237 \\
1238\end{array}$ & + & - . & & $\begin{array}{l}\text { FO } \\
\text { FO }\end{array}$ & - & - \\
\hline SEIBAL & $\begin{array}{l}1176 \\
1177 \\
1180 \\
1181 \\
1183\end{array}$ & $\begin{array}{l}- \\
-\end{array}$ & - & - & $\begin{array}{l}\text { FG } \\
\text { FG } \\
\text { FO } \\
\text { FO } \\
\text { FO }\end{array}$ & $\begin{array}{l}\text { Tres Naciones } \\
\text { Tres Naciones } \\
\text { Altar } \\
\text { Altar } \\
\text { Balancan }\end{array}$ & $\begin{array}{l}\text { Tres Naciones Gray } \\
\text { Poite Incised } \\
\text { Trapiche Incised } \\
\text { Pabellon Modeled-carved } \\
\text { Provincia Plano-relief }\end{array}$ \\
\hline $\begin{array}{l}\text { Altar de } \\
\text { Sacrificios }\end{array}$ & $\begin{array}{l}\text { Fo31 } \\
\text { Fo36 } \\
1179 \\
1182\end{array}$ & & $\begin{array}{l}- \\
-\end{array}$ & $\begin{array}{l}+ \\
+ \\
+\end{array}$ & $\begin{array}{l}\text { FO } \\
\text { FO } \\
\text { FO } \\
\text { FO }\end{array}$ & $\begin{array}{l}\text { Altar } \\
\text { Altar } \\
\text { Altar } \\
\text { Altar }\end{array}$ & $\begin{array}{l}\text { Altar Orange } \\
\text { Islas Gouged-incised } \\
\text { Altar Orange } \\
\text { Pabellon Modeled-carved }\end{array}$ \\
\hline Piedras Negras & $\begin{array}{l}162 \\
217 \\
218 \\
221 \\
318\end{array}$ & & - & $\begin{array}{l}+ \\
+\end{array}$ & $\begin{array}{l}\text { FG } \\
\text { FO } \\
\text { FO } \\
\text { FO } \\
\text { FP }\end{array}$ & $\begin{array}{l}\text { Chablekal } \\
\text { Balancan } \\
\text { Balancan } \\
\text { Altar } \\
\text { - }\end{array}$ & $\begin{array}{l}\text { Chicxulub Inclsed } \\
\text { Provincia Plano-relief } \\
\text { Provincia Plano-relief } \\
\text { Trapiche Incised } \\
\text { - }\end{array}$ \\
\hline San Jose del Rio & 880 & & & & FO & Matillas & Villahermosa Incised \\
\hline Tierra Blanca & $\begin{array}{l}29 \\
35 \\
36\end{array}$ & + & - & - & $\begin{array}{l}\text { FG } \\
\text { FG } \\
\text { FG }\end{array}$ & $\begin{array}{l}\text { Chablekal. } \\
\text { Chablekal } \\
\text { Chablekal }\end{array}$ & $\begin{array}{l}\text { Chablekal Gray } \\
\text { Chablekal Gray } \\
\text { Telchac Composite }\end{array}$ \\
\hline
\end{tabular}




\begin{tabular}{|c|c|c|c|c|c|c|c|}
\hline & & MICACEOUS & VOLCANIC & & & & \\
\hline SITE & SPECIMEN & MATRIX & DUST & FELDS PAR & WARE & CERAMIC GROUP & CERAMIC TYPE \\
\hline \multirow[t]{3}{*}{ Trinidad } & 25 & & & - & FO & - & - \\
\hline & 27 & - & - & - & FP & - & - \\
\hline & 271 & & - & & FO & silho & Pocboc Gouged-inclsed \\
\hline Calatrava & 224 & & & & FO & Balancen & Provincia Plano-relief \\
\hline Bajio & 1231 & & & & FO. & Silho & - Pocboc Gouged-incised \\
\hline \multirow[t]{12}{*}{ Palenque } & 56 & - & - & & FP & - & - \\
\hline & 58 & - & - & - & FG & Chablekal & Chablekal Gray \\
\hline & 74 & & & & FG & Chablekal & Chablekal Gray \\
\hline & 84 & & & & FG & Chableikal & Cholul Fluted \\
\hline & 88 & & - & + & FO & - & - \\
\hline & 89 & & + & & Fo & - & 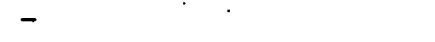 \\
\hline & 244 & & - & $\cdot$ & FO & A.ltar & Altar qrange \\
\hline & 248 & & & & $\mathbf{F P}$ & - & - \\
\hline & 249 & - & - & + & FP & - & - \\
\hline & 329 & - & + & - & FG & Chablekal & Chicxulub Inciged \\
\hline & 331 & & - & - & FG & Chablekal & Telchac Composite \\
\hline & 722 & - & - & & EG & Chablekal & Telchac Composite \\
\hline Miraflores & 235 & & & . & FO & Cunduecan & Buey Modeled \\
\hline Yoxtha & 336 & & & & FG & - & - \\
\hline \multirow[t]{9}{*}{ Tortuguero } & 38 & & & & FP & - & - \\
\hline & 39 & & - & + & FP & - & - \\
\hline & 40 & & - & + & FP & - & - \\
\hline & 41 & & - & - & FP & - & - \\
\hline & 42 & & - & + & FP & - & - \\
\hline & 43 & & - & & FP & - & - \\
\hline & 44 & & - & & FP & - & - \\
\hline & 45 & & $-\cdot$ & + & FP & Balanizan & Balancan Orange \\
\hline & 47 & & - & + & FP & Balanzan & Provincia Plano-relief \\
\hline
\end{tabular}




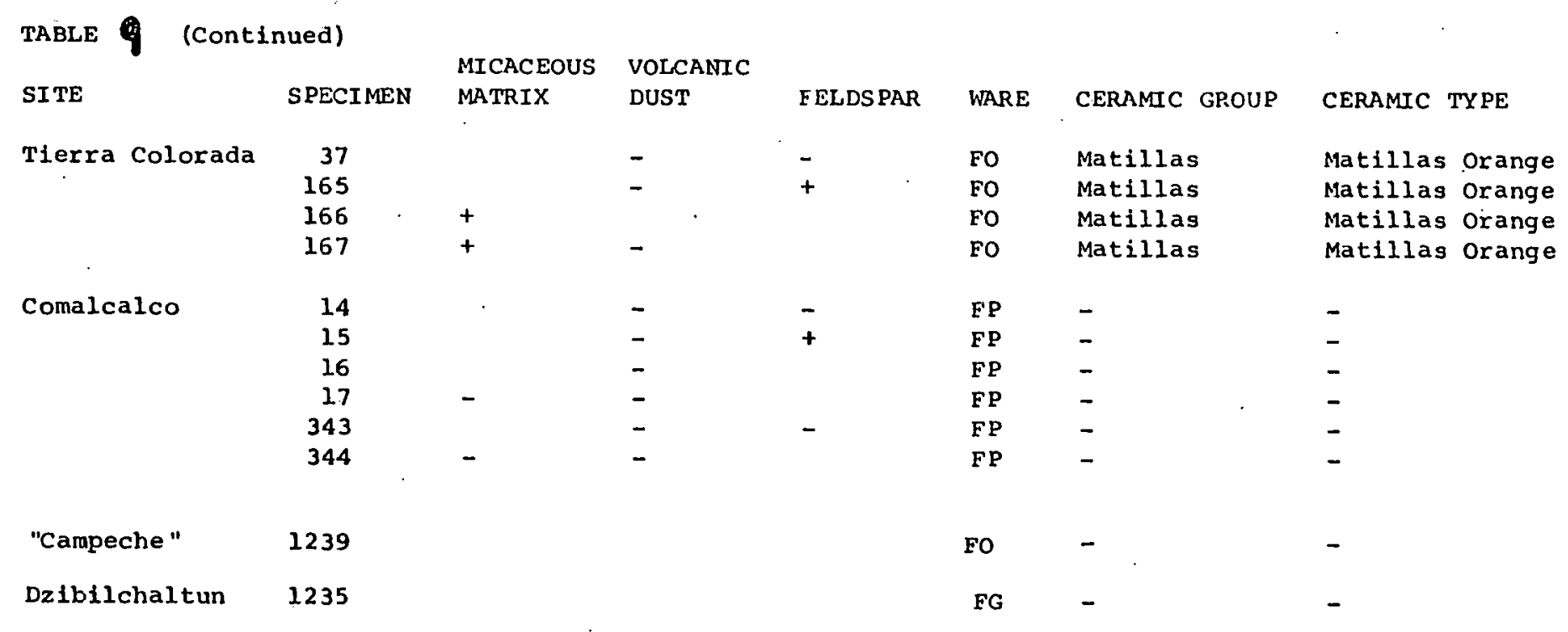


REGION SITE

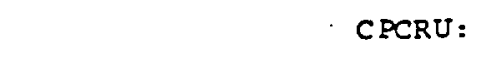

兽㽞 - Becan

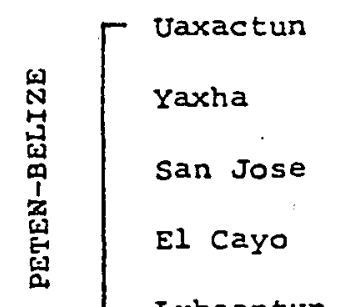

Tortuguero

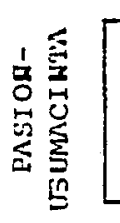

$$
\text { SEIBAI }
$$

Alțar de Sacrificios

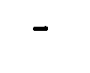

落

Hiearas Neguas

Arenitas

san Jose del K10. -

[.

$$
\text { Jonuta }
$$

Bajio

palenque Ejido

Palenque

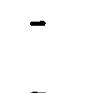


REGION SITE

CPCRU:

움욤 1 Becan

Tortu- 15

息 $\left[\begin{array}{l}\text { Uaxactun } \\ \text { Yaxha } \\ \text { San Jose } \\ \sum_{0}^{0} \\ \text { El Cayo } \\ \text { Lubaantun }\end{array}\right.$

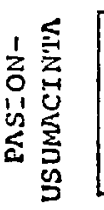

SEI BAI

guero

\begin{tabular}{lllll|l}
2 & 4 & 4 & 3 & $\begin{array}{c}\text { Un- } \\
\text { olaced }\end{array}$ \\
\hline
\end{tabular}

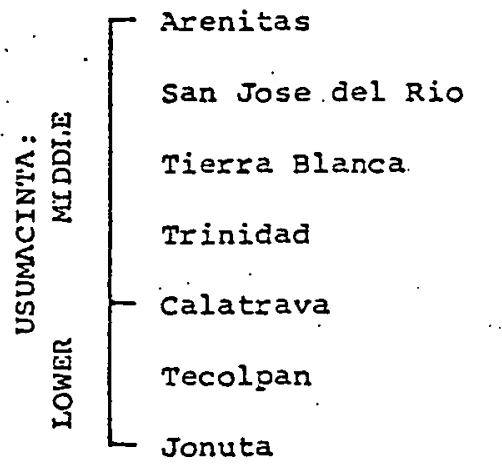

尊 $\left[\begin{array}{l}\text { Bajio } \\ \text { Palenque Ejido } \\ \text { Palenque } \\ \text { Miraflores } \\ \text { Yoxina } \\ \text { Tortuguero }\end{array}\right.$

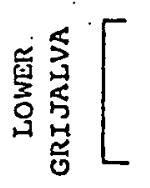

Tierra Colorada Cintla

Comalcalco

"Campeche"

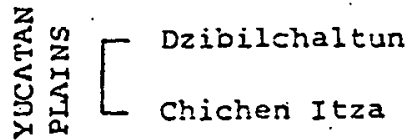

1

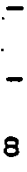

8

1

1
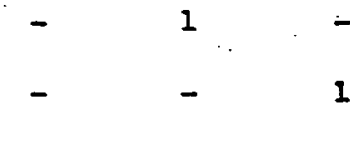

1

-

-
-
-

- 
CHARTIEKAL CERAMIC GROUP

(Gray + Black : Surfaces)

SITE

CPCREU:

Tortu-

quero

Piedras Negras.

Tierra Blanca

Ea.1 atrava

Innuta

Palenque

Dzibilchaltun

$-$
1

5

2

$\begin{array}{lll}- & - & 1\end{array}$

- - $\quad-$

$-$

$-$

1

1

4

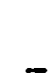

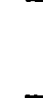

1
$-$

1

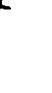

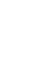

$-$

1
3

placed

3

6 
ALTAR CERAMIC GROUP

SITE

CPCRU:

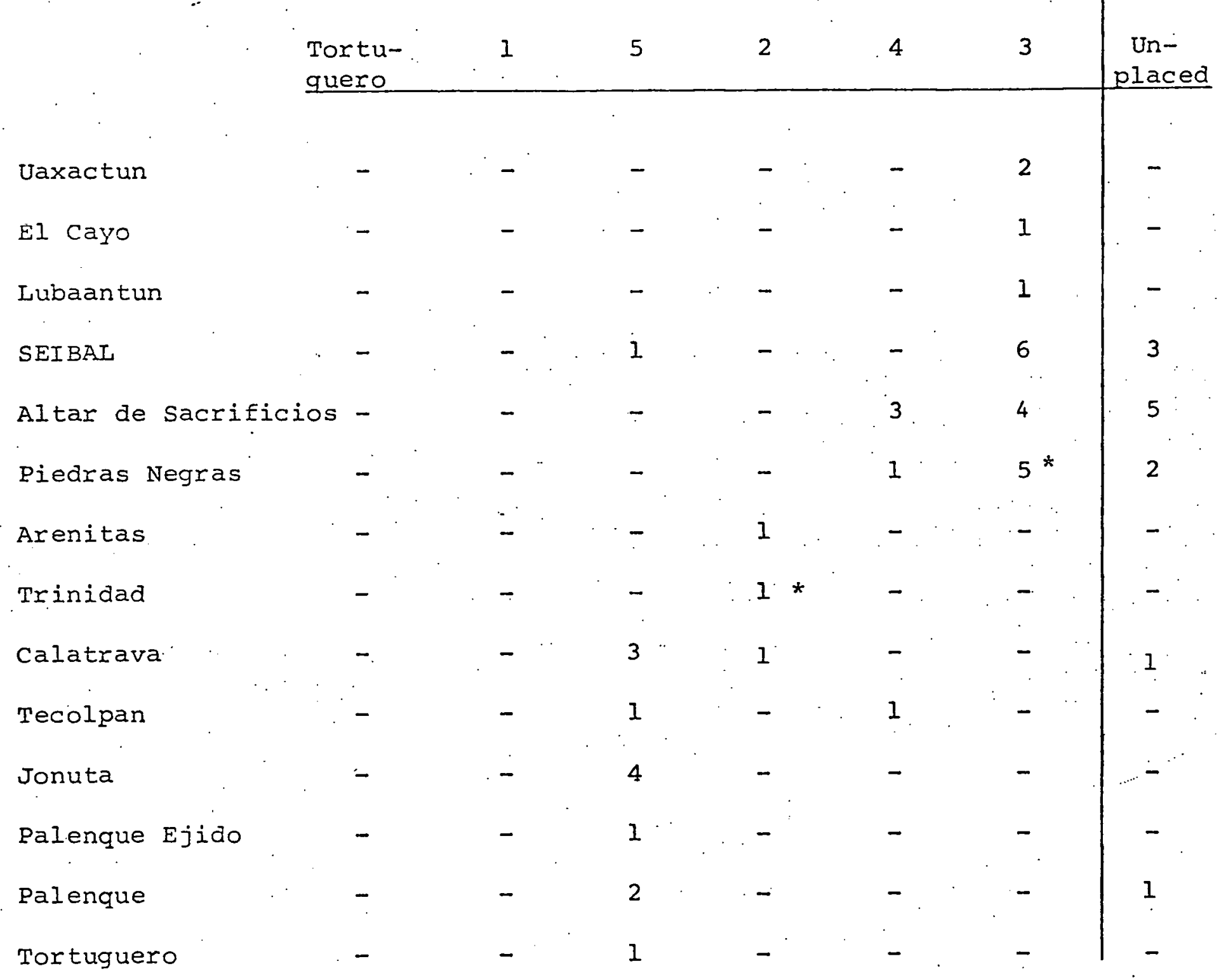


Tablé /2. 3

BALANCAN CERAMIC GROUP

SITE

CPCRU :

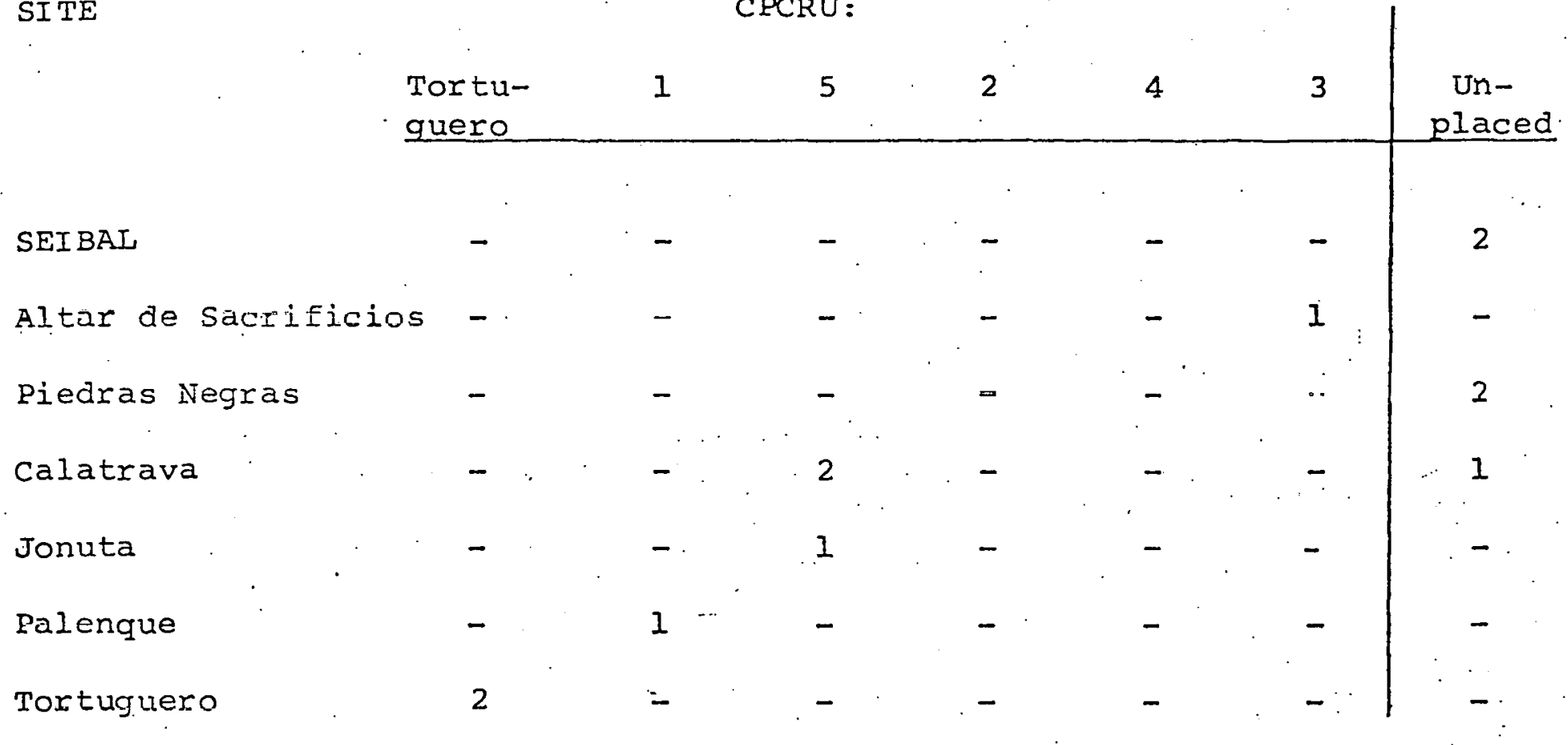


TRES NACIONES CERAMIC GROUP

SITE

CPCRU:

\begin{tabular}{|c|c|c|c|c|c|c|c|}
\hline 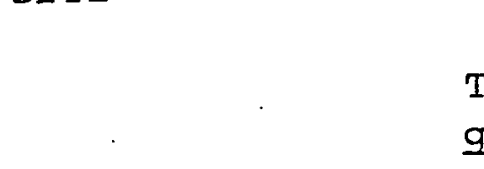 & $\begin{array}{l}\text { Tortu- } \\
\text { guero }\end{array}$ & 1 & 5 & 2 & 4 & 3 & $\begin{array}{l}: \text { Un - } \\
\text { placed }\end{array}$ \\
\hline SEIBAI & - & - & - & - & 1 & - & 2 \\
\hline Altar de sacrificio & os & - & - & 1 & 3 & 1 & - \\
\hline Piedras Negras & - & - & - & - & 1 & - & - \\
\hline Tecolpan & - & - & - & - & $1 *$ & - & - \\
\hline Palenque & - & - & 1 * & - & - & - & - \\
\hline
\end{tabular}


SILHO CERAMIC GROUP

SITE

\begin{tabular}{|c|c|c|c|c|c|c|}
\hline $\begin{array}{l}\text { Tortu- } \\
\text { guero }\end{array}$ & 1 & 5 & 2 & 4 & 3 & $\begin{array}{c}\text { Un- } \\
\text { placed }\end{array}$ \\
\hline - & - & $I^{*}$ & - & - & - & - \\
\hline- & - & - & 1 & - & - & 1 \\
\hline- & 1 & - & - & - & - & 1 \\
\hline$\dot{-}$ & 2 & - & - & - & - & 1 \\
\hline- & 2 & - & - & $=$ & - & 1 \\
\hline
\end{tabular}


MATILIAS CERAMIC GROUP

SITE

CPPCRU:

\begin{tabular}{llllll|c}
$\begin{array}{l}\text { Tortu- } \\
\text { quero }\end{array}$ & 1 & 5 & 2 & 4 & 3 & $\begin{array}{c}\text { Un- } \\
\text { placed }\end{array}$ \\
\hline- & - & - & - & - & - & 1 \\
- & - & 1 & - & - & - & - \\
- & - & - & - & - & - & 4 \\
- & - & - & $\ldots$ & - & - & -
\end{tabular}

Table 3.7

CUNDUACAN CERAMIC GROUUP

SITE

CPCRU:

\begin{tabular}{|c|c|c|c|c|c|c|}
\hline $\begin{array}{l}\text { Tortu- } \\
\text { guero }\end{array}$ & 1 & 5 & 2 & 4 & 3 & $\begin{array}{c}\text { Un- } \\
\text { placed }\end{array}$ \\
\hline - & - & - & - & - & - & 1 \\
\hline
\end{tabular}


Table $1 \% .1$

TYPES (BY CERAMIC GROUP)

Chablekal Ceramic Group Chablekal Gray

Chicxulub Incised

Cholul Fluted

Telchac composite

\section{CERAMIC TYPES}

SITE

\section{Tièra Blanca} Calatrava Jonuta

Palenque

\section{Piedras Negras} Dzibi-chaltun Palenque $2 \%$

palenque

Piedras Negras Tierra BIanca Palenque

Dzibi-chaltun

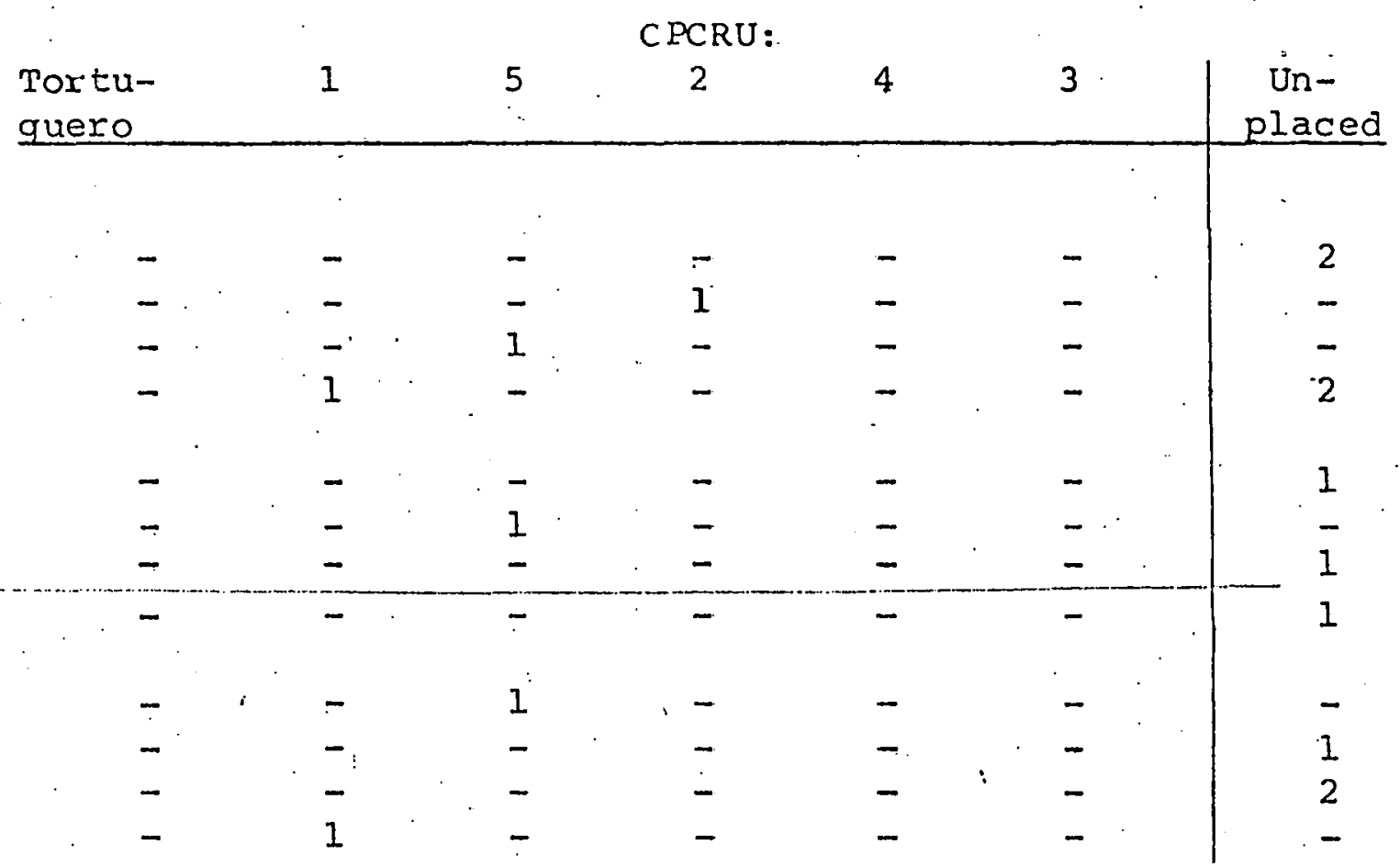


TYPES (BY CERAMIC GROUP)

SITE

Altar ceramic Group

Altar orange

\section{Cedro Gadrooned}

Islas Gouged-incised

Pabellon Modeled-carved

Trapiche Incised

Tumba Black-on-orange

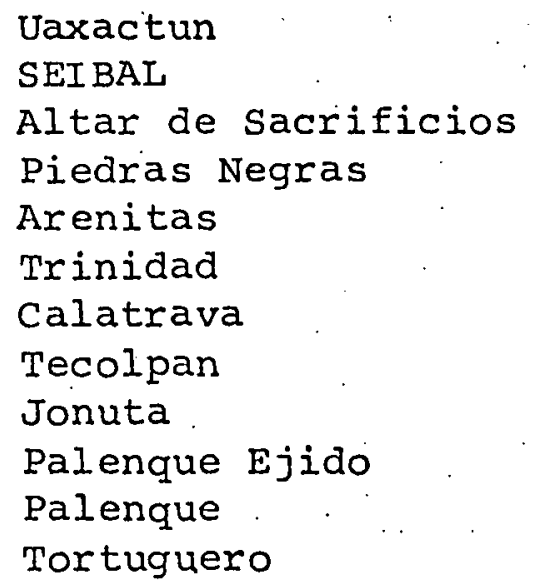

Uaxactun SEIBAL

2

4
placed

\section{El Cayo}

Lubaantun

SEIBAL

Altar de Sacrificios

Piedras Negras

SEIBAL

Piedras Negras

Jonuta

Palenque

SEIBAL

Altar de Sacrificios Calatrava

Jonuta

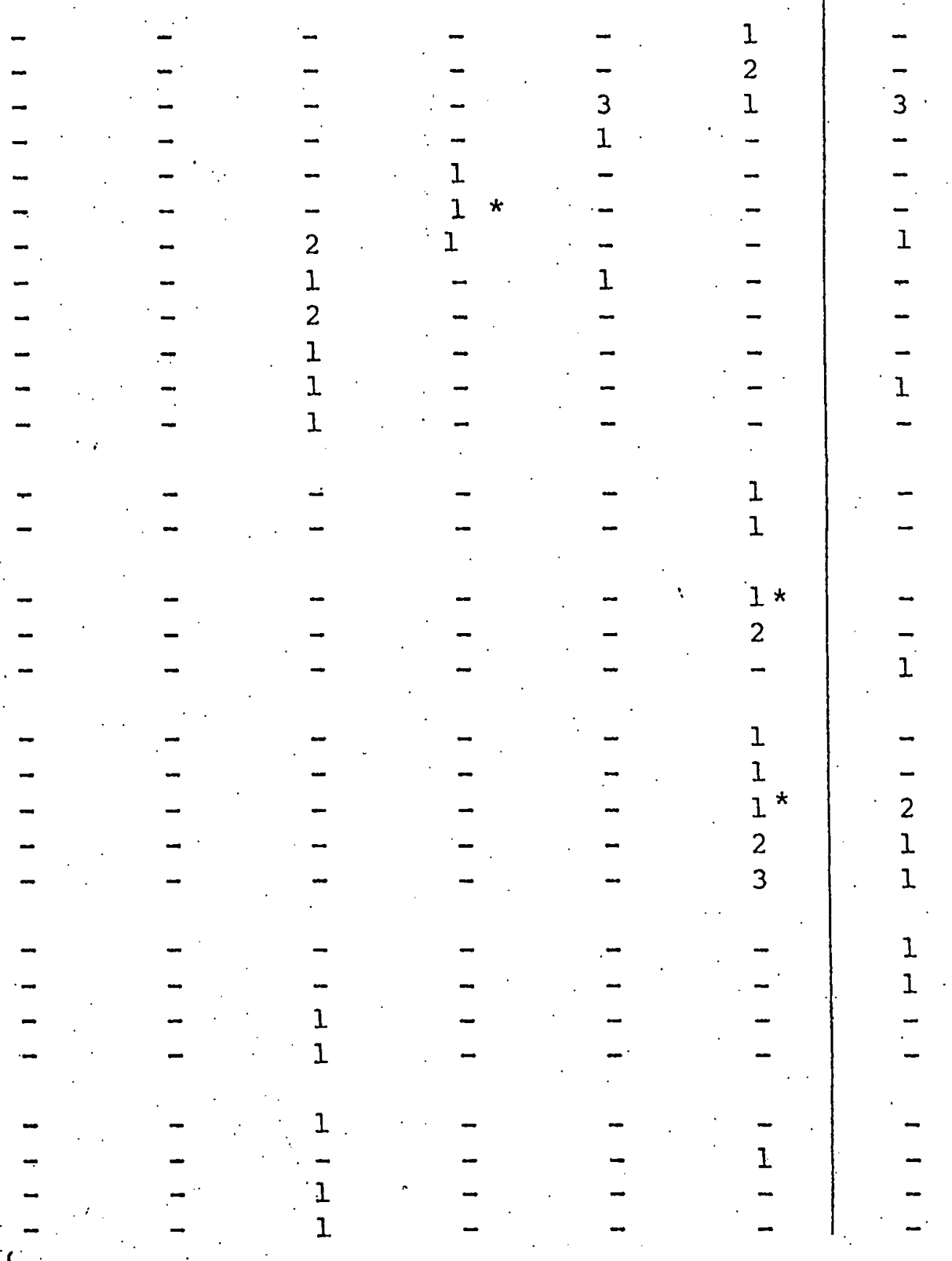


Table 33

CERAMIC TYPES

TYPES (BY CERAMIC GROUP)

Balancan Ceramic Group

Balancan orange

Provincia Plano-relief
SITE

Tort

\begin{tabular}{lcc|c}
2 & 4 & 3 & $\begin{array}{c}\text { Un- } \\
\text { placed }\end{array}$ \\
\hline- & - & - & - \\
- & - & - & 2 \\
- & - & 1 & - \\
- & - & - & 2 \\
- & - & - & 1 \\
- & - & - & - \\
- & - & - & - \\
- & - & - & -
\end{tabular}




\section{CERAMIC TYPES}

TYPES (BY CERAMIC GROUP)

\section{Tres Naciones Ceramic Group}

Chorrito Plano-relief

Poite Incised

Tres Naciones Gray
SITE

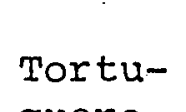

quero

Altar de Sacrificios -

SEIBAL

SEIBAL

Altar de Sacrificios

Piedras Negras

Tecolpan

Palenque
CPCRU:

5

1

$\cdot \cdot-5$

2

2

4

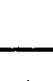

$\overline{-}$

- $\quad-\quad 1$

$-$

$-$

$1 *$

1

$-$

$\begin{array}{llllll}- & - & 1 & - & 1\end{array}$

$-$

$-$ 
Tatie $/ 3.5$

\section{CERAMIC TYPES}

TYPES (BY CERAMIC GROUP) SITE

\begin{tabular}{lllllll}
$\begin{array}{l}\text { Tortu- } \\
\text { guero }\end{array}$ & 1 & 5 & 2 & 4 & 3 & $\begin{array}{c}\text { Un- } \\
\text { placed }\end{array}$ \\
\hline
\end{tabular}

Silho Ceramic Group

\begin{tabular}{|c|c|}
\hline Champan Red-on-orange & Bajio \\
\hline Kilikan Composite & Chichen Itza \\
\hline Pocboc Gouged-incised & $\begin{array}{l}\text { Trinidad } \\
\text { Bajio }\end{array}$ \\
\hline Silho orange & Chichen Itza \\
\hline alton Black-on-orange & $\begin{array}{l}\text { Palenque } \\
\text { Chichen Itz }\end{array}$ \\
\hline
\end{tabular}

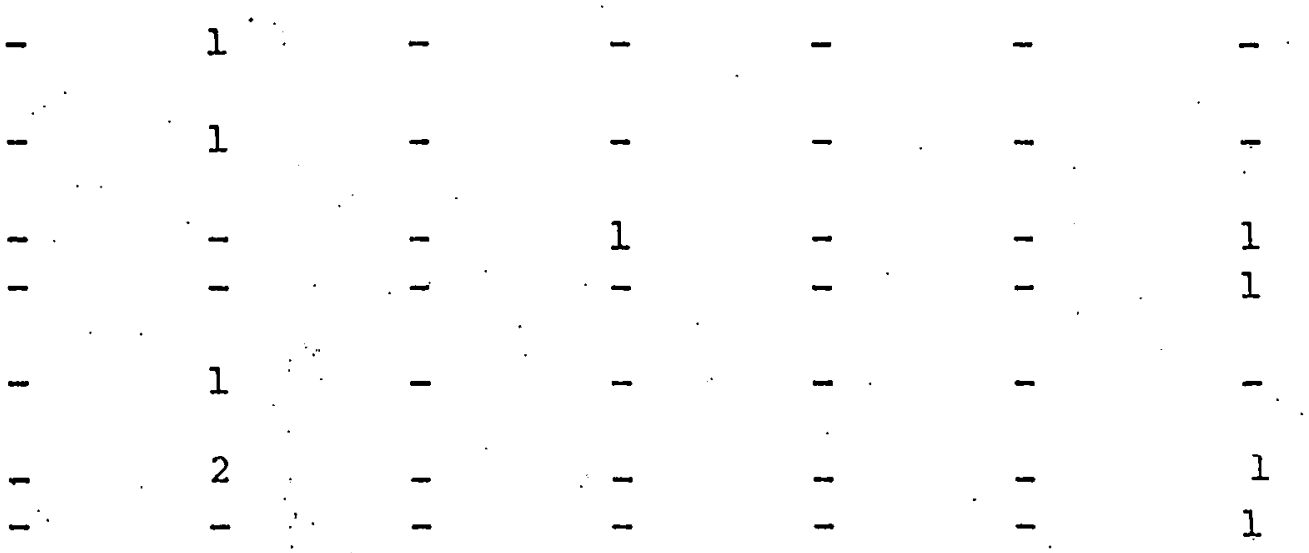


Table 6

\section{CERAMIC TYPES}

TYPES (BY CERAMIC GROUP) SITE

Matillas Ceramic Group

Matillas Orange

Calatrava

Tierra Colorada

Cintla

Viliahermosa Incised

San Jose del Rio

\begin{tabular}{|c|c|c|c|c|c|c|}
\hline $\begin{array}{l}\text { Tortu- } \\
\text { guero }\end{array}$ & 1 & 5 & $\begin{array}{c}\mathrm{PC} \\
2\end{array}$ & 4 & 3 & $\begin{array}{c}\text { Un- } \\
\text { placed }\end{array}$ \\
\hline & 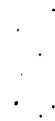 & & . & & & \\
\hline- & - & 1 & - & - & - & - \\
\hline- & - & - & - & - & - & 4 \\
\hline- & - & - & - & - & - & $2 *$ \\
\hline- & - & - & - & - & - & $I$ \\
\hline
\end{tabular}

Table 4.7

CERAMIC TYPES

TYPES (BY CERAMIC GROUP) SITE

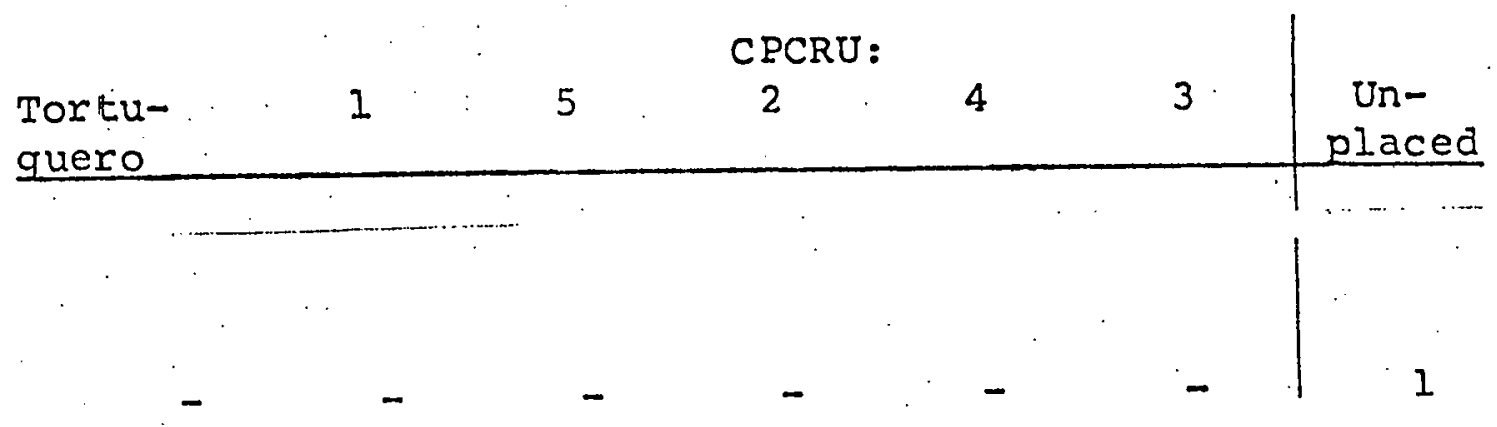


TABLE $\cdot 14$

COMBINED ALTAR AND BALANCAN GROUPS OF FINE ORANGE WAKE

SITE

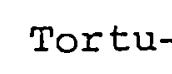

quero

1

Uaxactun

El Cayo

Lubaantun

SEIBAL

Altar de Sacriticios

Piedras Negras

5

2

4

$3 \mid \begin{gathered}\text { Un- } \\ \text { placed }\end{gathered}$

Arenitas

Trinidad

Calatrava

Tecolpan

Jonutà

Palenqua Ejido

Palenque

-1
$-\quad 1$

Tor tuguero

2

12

1 
Southern provenience:

\begin{tabular}{lr} 
Uaxactun & $(\mathrm{n}=2)$ \\
El Cayo & 1 \\
Lubaantun & 1 \\
Seibal & 8 \\
Altar & 13 \\
P.N. & 7 \\
\hline & \\
Total & 32.
\end{tabular}

Northern provenience:

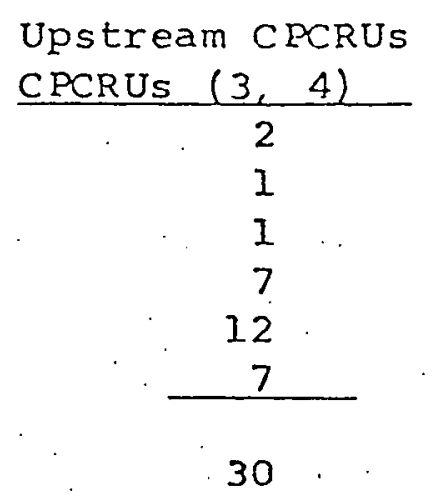

Downstream

CPCRUS $(2,5)$
1

1

2

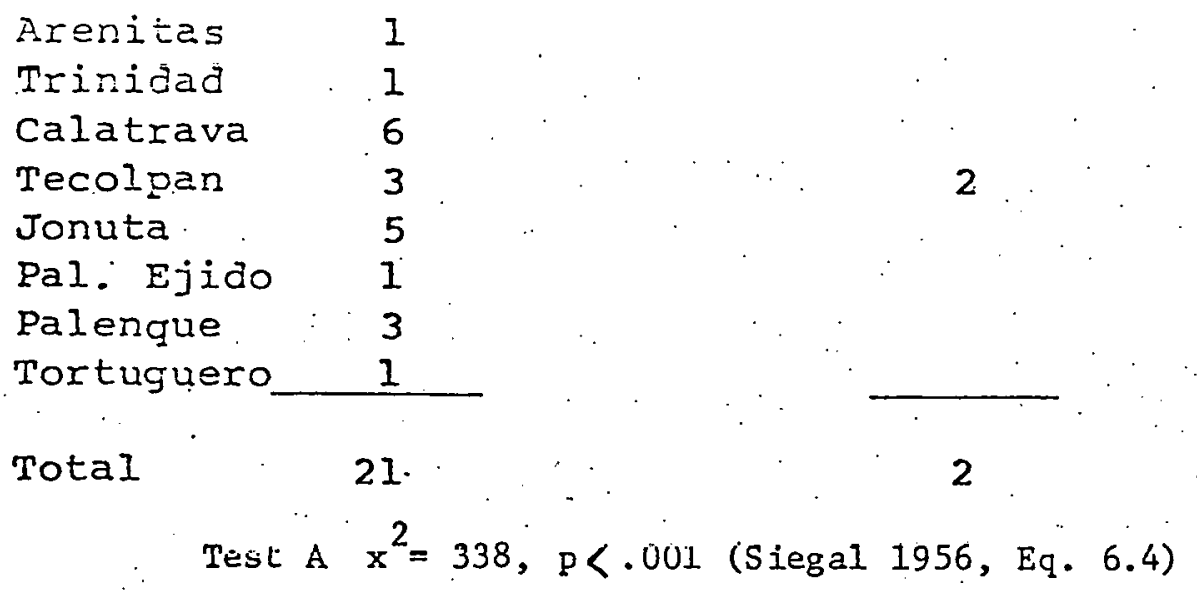

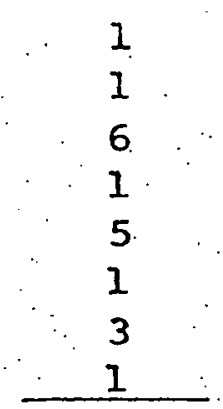

19

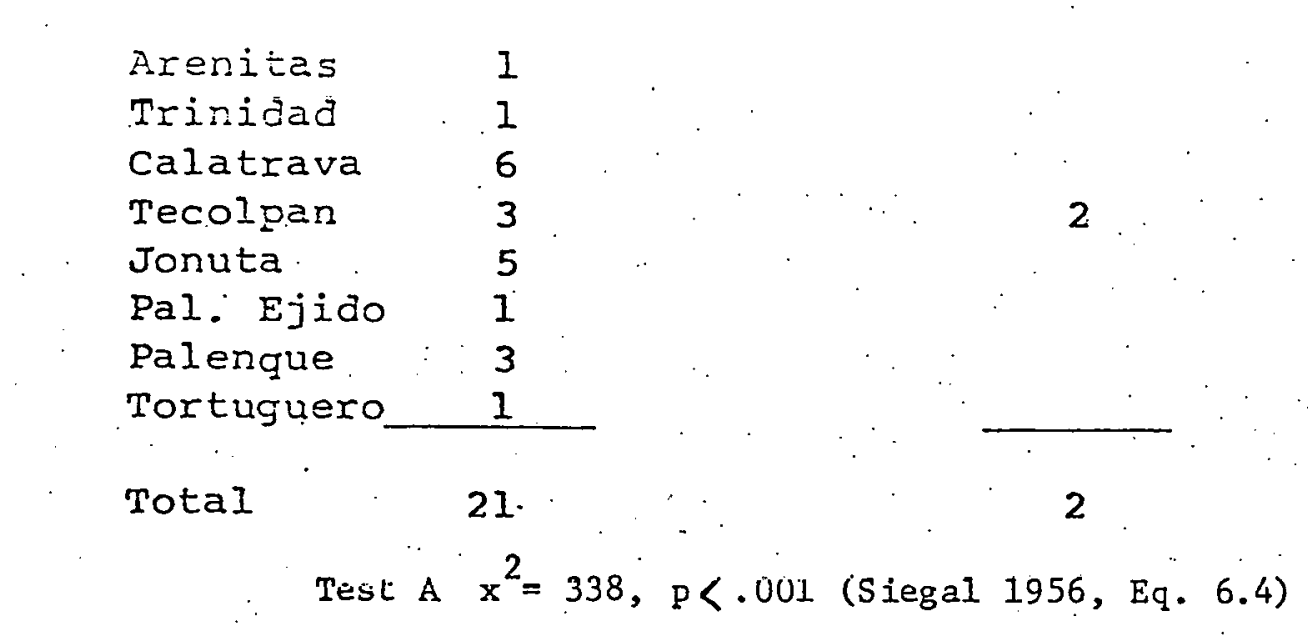

Upstream provenience:

Seibal

Altar

8

P.N.

13

7

Total

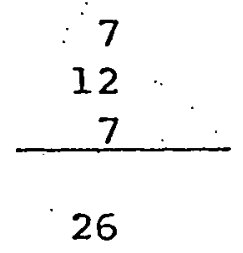

1

1

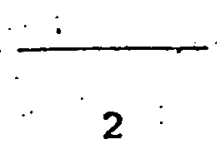

\section{Downstream provenience:}

\begin{tabular}{ll} 
Arenitas & 1 \\
Trinidad & 1 \\
Calatrava & 6 \\
Tecolpan & 3 \\
Jonuta & 5 \\
\hline
\end{tabular}

16

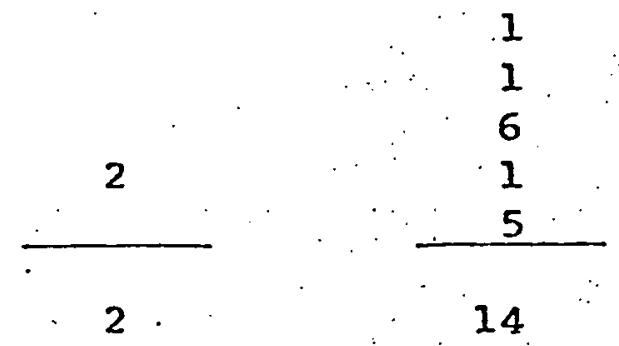

Test B $x^{2}=25, p<.001$ (Siegal 1956, Eq. 6.4) 